UNIVERSIDADE DE SÃO PAULO

FACULDADE DE FILOSOFIA, LETRAS E CIÊNCIAS HUMANAS DEPARTAMENTO DE CIÊNCIA POLÍTICA

DOUTORADO EM CIÊNCIA POLÍTICA

GUILHERME STOLLE PAIXÃO E CASARÕES

"O tempo é o senhor da razão"?

a política externa do governo Collor, vinte anos depois 
UNIVERSIDADE DE SÃO PAULO

FACULDADE DE FILOSOFIA, LETRAS E CIÊNCIAS HUMANAS

DEPARTAMENTO DE CIÊNCIA POLÍTICA

DOUTORADO EM CIÊNCIA POLÍTICA

\title{
"O tempo é o senhor da razão"? a política externa do governo Collor, vinte anos depois
}

\author{
Guilherme Stolle Paixão e Casarões \\ Tese apresentada ao Programa de Pós- \\ Graduação em Ciência Política da \\ Faculdade de Filosofia, Letras e Ciências \\ Humanas da Universidade de São Paulo, \\ para a obtenção do título de Doutor em \\ Ciência Política
}

Orientador: Prof. Dr. Paolo Ricci 
Folha de Aprovação

\title{
Guilherme Stolle Paixão e Casarões
}

\author{
“O TEMPO É O SENHOR DA RAZÃO"? \\ a política externa do governo Collor, vinte anos depois
}

\begin{abstract}
Tese apresentada ao Programa de Pós-Graduação em Ciência Política da Faculdade de Filosofia, Letras e Ciências Humanas da Universidade de São Paulo, sob a orientação do Prof. Dr. Paolo Ricci, para a obtenção do título de Doutor.
\end{abstract}

Aprovado em:

Banca examinadora

Prof. Dr. Paolo Ricci

Universidade de São Paulo

Prof. Dr. Shiguenoli Miyamoto

Universidade Estadual de Campinas

Prof. Dr. Tullo Vigevani

Universidade Estadual Paulista

Prof. Dr. Amâncio Oliveira

Universidade de São Paulo

Prof. Dr. Brasilio Sallum Jr.

Universidade de São Paulo 


\section{Resumo}

Esta tese tem como objetivo analisar a política externa do governo Collor (1990-1992) a partir do marco conceitual da autonomia pela modernização. Trabalha-se com a hipótese de que, na qualidade de potência média recém-industrializada, as forças estruturais ou sistêmicas direcionam mais a política externa brasileira do que as demandas domésticas. Em termos mais específicos: um país como o Brasil do início da década de 1990, no qual prevaleciam profundas vulnerabilidades sociais e econômicas, foi obrigado a adotar uma inserção internacional reativa, que se desenhava muito ao sabor dos interesses dos países com quem se tinham laços de dependência (como os países industrializados) e, sobretudo, dos Estados Unidos da América. Isso não significou, no entanto, que a política externa tenha adotado o tão propugnado alinhamento automático. Nos dois anos e meio de governo, houve tentativas de resistência às pressões sistêmicas, muitas das quais malfadadas - forçando-nos a concessões controversas - e muitas outras positivas - reforçando a autonomia brasileira. Essa é a segunda hipótese que essa tese oferece: a política externa do governo Collor possuiu quatro momentos distintos, cada qual com uma característica e uma ênfase, mas todos guiados por um princípio diplomático caro ao Brasil, o da busca pela autonomia, e uma estratégia comum, a modernização.

Palavras-chave: política externa; governo Collor; autonomia; modernização; diplomacia 


\begin{abstract}
This dissertation aims to analyze president Fernando Collor's foreign policy (1990-1992) within the conceptual framework of autonomy through modernization. We argue that, as a newly-industrialized middle-power, the structural or systemic forces guide Brazil's foreign policy more than the country's domestic demands. In more specific terms: a country like Brazil, in the early 1990s, which suffered from profound social and economic vulnerabilities, was forced to adopt a reactive international orientation, which was led according to the interests of countries with whom Brazil had dependency ties (as the industrialized powers) and, above all, the United States of America. It did not mean, however, that foreign policy automatically aligned with the US. In Collor's two and a half years in office, there were several attempts to resist the systemic pressures, many of which failed - forcing us to controversial concessions - and many others which succeeded - reinforcing Brazil's autonomy. This is the second hypothesis this dissertation offers: Collor's foreign policy can be divided in four different moments, each one guided by a characteristic and an emphasis, but all oriented by the same diplomatic principle, the quest for autonomy, and a common strategy, modernization.
\end{abstract}

Keywords: foreign policy; Collor administration; autonomy; modernization; diplomacy 


\section{Sumário}

\section{Lista de siglas 8}

\section{Agradecimentos 10}

\section{Introdução 11}

A tese: autonomia pela modernização 12

Metodologia 19

\section{CAPÍTULO 1}

A "economia política da política externa brasileira": pressupostos e desdobramentos 23

1.1.Uma nova proposta para a análise da política externa brasileira 30

1.2.Teses sobre a política externa do governo Collor 36

1.3.Uma interpretação alternativa: a autonomia pela modernização 41

\section{CAPÍTULO 2}

A corrida presidencial de $\mathbf{1 9 8 9}$ a partir das questões internacionais 54

2.1. O candidato Collor vai à Europa em busca de identidade política 55

2.1.1. A disputa pelo centro 67

2.2. A consolidação do programa de governo 69

2.3. Questões internacionais e a reta final da campanha 75

2.4. O segundo turno das eleições e o discurso de modernização competitiva 81

\section{CAPÍTULO 3}

\section{As viagens do presidente-eleito 85}

3.1. A viagem de férias 85

3.2. A construção da agenda internacional 88

3.3. A definição do novo governo 106

\section{CAPITULO 4}

\section{Modernização na retórica, autonomia na prática 116}

4.1. O discurso de posse e o sentido das relações internacionais do Brasil 116

4.2. Do discurso à prática: modernização e integração competitiva 120

4.3. A relação com os Estados Unidos e o problema da dívida externa 123

4.4. A autonomia em marcha: integração regional 138

4.4.1. O "choque sistêmico": a Iniciativa para as Américas 142

4.4.2. Divergências e oportunidades na integração sub-regional 144

4.5. Itamaraty de volta ao centro: Guerra do Golfo e a "crise dos reféns" 148

4.5.1. O descolamento entre presidente e diplomacia: duas frentes simultâneas 161

4.6. O desfecho: desconfianças recam sobre o Brasil 164

\section{CAPÍTULO 5}

Modernização forçada, autonomia retórica 167

5.1. O novo desenho da política externa brasileira 168

5.2. Dívida externa 172

5.2.1. Sai o 'estilo soft', entra o terceiro-mundismo 180

5.2.2. O longo caminho das negociações 182

5.3. As tecnologias de uso dual 184

5.4. A consolidação da autonomia: Rose Garden Agreement 192 
5.4.1. Mantendo a frente unida 194

5.5. "Diplomacia com as próprias mãos": o périplo africano 198

5.6. A reformulação conceitual: o discurso nas Nações Unidas 202

\section{CAPÍTULO 6}

Autonomia e modernização 206

6.1. O sentido da nomeação de Celso Lafer 206

6.2. O realinhamento entre discurso e prática diplomática 208

6.3. Aspectos gerais da política externa de Fernando Collor e Celso Lafer 212

6.4. Meio ambiente como modernização 213

6.5. Integração como modernização 214

\section{Considerações finais 219}

\section{Referências bibliográficas 225}




\section{Lista de siglas}

ABDI - Agência Brasileira de Desenvolvimento Industrial

ABIMDE - Associação Brasileira de Indústrias de Materiais de Defesa e Segurança

AIEA - Agência Internacional de Energia Atômica

ALADI - Associação Latino-Americana de Integração

ALALC - Associação Latino-Americana de Livre Comércio

APE - Análise de Política Externa

ASF - Força de Alerta Africana

$\mathrm{CE}$ - Comunidade Europeia

CEE - Comunidade Econômica Europeia

CIA - Agência Central de Inteligência (ou Central Intelligence Agency)

CSNU - Conselho de Segurança das Nações Unidas

DF - Distrito Federal

ECEME - Escola de Comando e Estado-Maior do Exército

ESG - Escola Superior de Guerra

EUA - Estados Unidos da América

FFAA - Forças Armadas

FSP - Folha de São Paulo

G-7 - Grupo dos Sete

G-77 - Grupo dos Setenta e Sete

JB - Jornal do Brasil

MERCOSUL - Mercado Comum do Sul (ou Mercado do Cone-Sul)

MNA - Movimento dos Não-Alinhados

MRE (ou Itamaraty) - Ministério das Relações Exteriores

NYT - New York Times

OEA - Organização dos Estados Americanos 
OESP - O Estado de São Paulo

ONU - Organização das Nações Unidas

OTAN - Organização do Tratado do Atlântico Norte

PEB - Política Externa Brasileira

PIB - Produto Interno Bruto

PKO - Operações de Paz (ou Peacekeeping Operations)

RI - Relações Internacionais

TIAR - Tratado Interamericano de Assistência Recíproca

UE - União Europeia

VANT - Veículo Aéreo Não-Tripulado

ZOPACAS - Zona de Paz e Cooperação do Atlântico Sul 


\section{Agradecimentos}

O fechamento dessa tese envolve um misto de alegria e tristeza. Alegria, claro, porque toda etapa concluída na nossa trajetória pessoal é motivo de celebração, ainda mais quando estamos falando do estágio derradeiro, do "trabalho de uma vida" (embora saibamos que, no fundo, é só mais um degrau). Tristeza, por outro lado, porque - ao contrário de outros textos que escrevi - não tive vontade de chegar ao final. Queria escrever mais, ler mais, conversar mais com as pessoas que me ajudaram a montar esse quebra-cabeça intelectual, cujo resultado, embora de responsabilidade inteiramente minha, é tributário a várias pessoas, a quem ofereço meus sinceros agradecimentos.

Não poderia deixar de agradecer, em primeiro lugar, ao meu orientador, Paolo Ricci, pela disposição de me ajudar em situações extremas, contra o relógio, com uma paciência admirável e um olhar metodológico incomparável. No ambiente uspiano, devo minha gratidão aos professores Janina Onuki e Brasilio Sallum Jr. Pelo apoio desde a qualificação; Amâncio Oliveira, Bernardo Ricupero, Rogério Arantes, por aulas e conversas enriquecedoras. Rai, Vasne e os demais funcionários da secretaria do DCP foram verdadeiros anjos da guarda durante esse processo.

Outros professores, colegas e amigos participaram diretamente do processo da tese, oferecendo ideias, interrogações, apoio intelectual e muitas vezes suporte emocional. Agradeço aos professores Tullo Vigevani, Carlos Eduardo Carvalho, Carlos Aurélio Faria, Matias Spektor; aos amigos-professores Fernanda Magnotta, Dawisson Lopes, Lucas Rezende, Raquel Rocha, Helena Margarido, Cecilia Baeza, Gunther Rudzit, Oliver Stuenkel; aos amigos-diplomatas Luiz Feldman, Bruno Simões, Filipe Nasser, João Vargas, Carlos Ceglia, Bárbara Boechat; aos amigos e colegas de Rio Branco, ESPM, FGV e FAAP, Dantas e USP, em particular Alexandre Uehara, Pedro Júnior, Denilde Holzhacker, Angela Tsatlogiannis, Gilberto Sarfati, José Maria, Sérgio Gil, Anapaula Iacovino, Tatiana Berringer, Lucas Leite, Fernando Abrucio, Cláudio Couto, Marco Antônio Teixeira, André Carvalho, Antonio Gelis, Salomão Lima, Laís Thomaz, Juliano Aragusuku, Fernando Brancoli e tantos outros que, nos últimos quatro anos, sempre estavam prontos para ouvir a ajudar; aos chefes, atuais ou eternos, Rodrigo Cintra, Luiz Alberto Machado, Edman Altheman; aos alunos, muitos dos quais se mostraram dispostos a ouvir sobre minha tese e debatê-la nas aulas de política externa brasileira.

A ajuda Vitor Olivier foi essencial para a coleta de dados do trabalho, nos arquivos do Itamaraty. Agradeço também aos funcionários do MRE que viabilizaram a pesquisa documental. Flávio Correa e Fátima Pinto Coelho me abriram portas a algumas figuras-chave. E não poderia deixar de mencionar as autoridades que, com enorme generosidade, cederam seus depoimentos para a confecção do texto: Francisco Rezek, João Santana, Fernando Collor de Mello, Marcos Azambuja, Gelson Fonseca Júnior, Paulo Tarso Flecha de Lima, Celso Lafer e Rubens Ricupero - este, mais que uma personalidade política e um objeto de estudo, um chefe carinhoso e figura inspiradora.

Por fim, gostaria de agradecer a meus pais, Denise e Roberto, minhas avós Noeme e Ema (in memoriam) e meus irmãos, Ludimila e João Francisco, pelo amor incondicional e o apoio constante. Essa tese, no entanto, não teria existido se não fosse meu núcleo familiar, Marina, Ana Leticia e Samuel, a quem não só agradeço com todo meu coração, mas também ofereço um pedido de desculpas, pois certamente foram os mais penalizados ao longo do percurso. Aos três amores da minha vida, dedico o esforço e a abdicação que se transformaram nas páginas a seguir. 


\section{Introdução}

Os estudos sobre política externa brasileira ganharam bastante densidade - teórica e empírica - nas últimas duas décadas, principalmente em decorrência da expansão do ensino de Relações Internacionais no Brasil. Amparado em clássicos da História Diplomática ou nos cânones da análise de política externa aplicada ao caso brasileiro, um sólido repertório constituiu-se na área, oferecendo aos estudiosos uma variedade de temáticas, ângulos analíticos e matrizes teóricas que dão sentido interpretativo às relações internacionais do Brasil. De Vargas a Lula, poucos são os temas ainda inexplorados da política externa brasileira.

Curiosamente, um interregno de nossas relações com o mundo permanece obscurecido pela negligência histórica. Ao governo Collor de Mello, em seu breve período de março de 1990 a setembro de 1992, foi dada muito pouca atenção analítica, tanto em termos relativos quanto absolutos. Relativos, porque o momento "collorido" da política externa brasileira não mereceu uma obra de fôlego sequer, e os artigos que tratam do tema, em geral, foram escritos no calor do processo de impeachment e carregam, nos argumentos, o peso histórico da crise política que se instaurou no país naqueles anos ${ }^{1}$. Se levarmos em conta a expressiva proliferação recente de estudos sobre a política externa de governos como Geisel ${ }^{2}$, Figueiredo ${ }^{3}$ e Sarney ${ }^{4}$, a ausência de trabalhos sobre Collor chama particularmente a atenção. Absolutos, porque os artigos (e mesmo teses e dissertações) sobre o tema são exíguos, não passando de uma dezena aqueles que tratam diretamente do período.

Dito isto, este trabalho tem como objetivo principal suprir uma importante lacuna bibliográfica nos estudos de política externa brasileira, buscando oferecer uma análise meticulosa do período de abril de 1989, quando começa a campanha presidencial que elege

\footnotetext{
${ }^{1}$ Os textos mais importantes do período, mas certamente influenciados pelas circunstâncias históricas e pelo sentimento de crise de governo, são Batista, Paulo Nogueira. "A Política Externa de Collor: modernização ou retrocesso?”. Política Externa, vol. 1, no. 4, 1993; Cruz Jr., Ademar Seabra de; Cavalcante, Antonio Ricardo F.; Pedone, Luiz. "Brazil's Foreign Policy Under Collor". Journal of Interamerican Studies and World Affairs, vol. 35, no. 1, 1993.

${ }^{2}$ Spektor, Matias. Kissinger e o Brasil. Rio de Janeiro: Record, 2009; Pinheiro, Leticia. Foreign Policy Decision-Making Under the Geisel Government: the president, the military and the Foreign Ministry. Brasília: FUNAG, 2013.

${ }^{3}$ Ferreira, Túlio Sérgio Henriques. "A ruína do consenso: a política exterior do Brasil no governo Figueiredo (de 1979 a 1985). Revista Brasileira de Política Internacional, vol. 49, no. 2, 2006; Ferreira, Túlio Sérgio Henriques. O Universalismo e seus descontentes: a política exterior do Brasil no governo Figueiredo (de 1979 a 1985). Curitiba: Juruá, 2009; Simon, Roberto. "As duas aberturas: redemocratização e política internacional no Brasil de Figueiredo (1979-1985)”. Dissertação de mestrado (Programa San Tiago Dantas). São Paulo, 2013.

${ }^{4}$ Pereira, Analúcia Danilevicz. A Política Externa do Governo Sarney. Porto Alegre: Ed. UFRGS, 2003; Côrtes, Octávio Henrique Dias Garcia. A Política Externa do Governo Sarney: o início da reformulação de diretrizes para a inserção internacional do Brasil sob o signo da democracia. Brasília: FUNAG, 2010.
} 
Collor, e setembro de 1992, quando o presidente é afastado após a abertura do processo de impeachment. Trata-se de continuidade de pesquisa de mestrado realizada entre 2009 e $2011^{5}$, na qual se identificaram os fatores de mudança da política externa brasileira na virada da década de 1980 e sugeriu-se uma interpretação de três níveis analíticos (mudanças na correlação de forças do sistema internacional; mudanças no modelo vigente de relação Estado-sociedade no Brasil; mudanças na composição e na estrutura do Itamaraty) para compreender a orientação internacional do governo Collor de Mello.

Embora o trabalho anterior tivesse a intenção de jogar luz sobre a mudança, uma de suas conclusões foi a de que, ao contrário do que sugere a tese tradicional do alinhamento automático com os Estados Unidos, houve diversas nuances, resistências e avanços táticos em direção à América do Sul, ao multilateralismo ou ao próprio Terceiro Mundo, em função da própria correlação de forças domésticas, sistêmicas-estruturais e burocráticas que interagiam no contexto da política externa. Naquela oportunidade, chamamos a resultante dessas transformações de americanismo mitigado, uma "uma inserção que zela pela autonomia do Brasil frente ao sistema internacional, mas cujo raio de ação está limitado pelos constrangimentos impostos tanto pelas transformações estruturais em marcha, quanto pelas novas circunstâncias domésticas - que, naturalmente, ressoam também sobre a diplomacia, embora com muito mais vagar"6.

A pesquisa anterior, contudo, deixa diversos elementos em aberto. A principal pergunta não respondida - e que nos servirá, aqui, como a principal questão de trabalho - é a seguinte: quais elementos condicionaram a formulação e a condução da política externa nos anos Collor? Em outras palavras: mesmo sendo a mudança visível (embora possa se discordar do grau, como dissemos), qual correlação de forças sustentou a condução da política externa até o final? Mais que isso, pode-se falar em uma única política externa ao longo do curto período daquele governo?

\section{A tese: autonomia pela modernização}

A tese aqui aventada se desdobra em duas respostas, portanto. A primeira delas é a de que na qualidade de potência média recém-industrializada, as forças estruturais ou sistêmicas direcionam mais a política externa brasileira do que as demandas domésticas. Em

\footnotetext{
${ }^{5}$ Casarões, Guilherme. "As três camadas da política externa do governo Collor: poder, legitimidade e dissonância”. Dissertação de mestrado (Programa San Tiago Dantas). São Paulo, 2011.

${ }^{6}$ Casarões, Guilherme. "O Papel do Itamaraty na definição da política externa do governo Collor de Mello".

Revista Brasileira de Política Internacional, vol. 55, no. 1, 2012.
} 
termos mais específicos: um país como o Brasil do início da década de 1990, no qual prevaleciam profundas vulnerabilidades sociais e econômicas, foi obrigado a adotar uma inserção internacional reativa, que se desenhava muito ao sabor dos interesses dos países com quem se tinham laços de dependência (como os países industrializados) e, sobretudo, dos Estados Unidos da América. O quadro tornava-se particularmente crítico diante da ausência, ao menos temporária, de pólos alternativos de poder com os quais o Brasil poderia interagir como forma de contrapeso às pressões vindas da potência hegemônica.

Isso não significa, no entanto, que a política externa tenha adotado o tão propugnado alinhamento automático. Ser reativa não é sinônimo de ser passiva. Foram dois anos e meio de tentativas de resistência às pressões sistêmicas, muitas das quais malfadadas - forçandonos a concessões controversas - e muitas outras positivas - reforçando a autonomia brasileira. Essa é a segunda resposta que essa tese oferece: a política externa do governo Collor possuiu quatro momentos distintos, cada qual com uma característica e uma ênfase, mas todos guiados por um princípio diplomático caríssimo ao Brasil, o da busca pela autonomia, e uma estratégia comum, a modernização.

Definida de maneira sumária, entendemos autonomia, na sua acepção política, como "uma condição do Estado-nação que lhe possibilita articular e alcançar objetivos políticos de forma independente" ${ }^{\text {7 }}$. Pensada de outra forma, como sugerem Tullo Vigevani e Gabriel Cepaluni, o conceito se relacionaria com a capacidade de um país em se proteger dos efeitos mais nocivos do sistema internacional e dos constrangimentos impostos pelas potências ${ }^{8}$. Modernização, por sua vez, pode ser compreendida a partir de duas noções paralelas, ambas representando uma síntese dos novos padrões de relacionamento entre Estado e mercado e Estado e sistema internacional: em primeiro lugar, a "integração, em um só processo, de eixos como a reestruturação industrial, a aceleração do progresso técnico-científico e uma nova inserção na economia internacional" ${ }^{9}$; em segundo lugar, a atualização da agenda internacional brasileira em direção aos "novos temas", sobretudo àqueles ligados aos anseios da sociedade civil global.

Dito de uma outra maneira, a modernização do Brasil - em suas facetas doméstica e internacional - foi a maneira que o governo Collor encontrou para manter a autonomia do país frente a um sistema internacional muito pouco permissivo a seus próprios interesses. Concessões, quando houve, foram fruto de pressões intensas, aplicadas muitas vezes de

\footnotetext{
${ }^{7}$ Russell, Roberto e Tokatlian, Juan Gabriel. "From Antagonistic Autonomy to Relational Autonomy: a theoretical reflection from the Southern Cone". Latin American Politics and Society, vol. 45, no. 1, 2003, p. 1.

${ }^{8}$ Vigevani e Cepaluni

${ }^{9}$ Reis Velloso, João Paulo dos. Inovação e Sociedade. Rio de Janeiro: José Olympio, 1994, p. 4.
} 
maneira descoordenada, as quais se buscou compensar com ganhos em outras frentes. A agenda do Brasil no mundo é, afinal, extremamente complexa dada a pluralidade de temas que abarca.

Mas a autonomia pela modernização, termo que utilizaremos para encapsular o sentido da tese, não se traduziu perfeitamente da concepção ideal à prática diária. Não queremos que o conceito ora proposto se confunda com mera retórica diplomática, que povoou a história da política exterior brasileira com chavões que, por mais que orientassem a prática internacional, às vezes lidavam com circunstâncias de profunda desconexão com a realidade social. Temos que olhar para dentro: a capacidade que o Brasil teve de resistir às forças que o arrastavam para a subserviência internacional - e não estamos negando que elas tenham existido vivamente - foi muitas vezes limitada não só pela posição do país no mundo, mas também pela constelação de atores e interesses políticos domésticos que nem sempre atuaram de maneira harmoniosa. O capítulo 1 será integralmente dedicado à construção de discussão de um modelo de análise que contemple essas supostas inconsistências da conduta internacional do Brasil.

No caso do governo Collor, aliás, o processo - entremeado pelas disputas setoriais, pelas clivagens políticas e pela perene crise econômica - foi bastante conflituoso, do começo ao fim. Num país que estava almejando se abrir para o mundo, seja pelas reformas estruturantes que buscavam reorganizar as relações entre Estado e sociedade, seja pelas forças (muitas vezes irresistíveis) da globalização econômica, a política externa tornou-se uma atividade que envolvia, direta ou indiretamente, um número crescente de interesses. Isso também soma à complexidade de nossa agenda internacional e não permite leituras dicotômicas que simplifiquem o argumento em demasia.

Outro elemento que se deve ressaltar é o papel do presidente da República neste processo. Não é preciso, aqui, ressuscitar os argumentos já discutidos pela literatura a respeito do "estilo Collor" de governar, tanto naquilo que se relaciona a suas características pessoais quanto no tocante às preferências ideológicas ${ }^{10}$. Isso, a rigor, influi muito pouco no resultado. Partimos, para fins analíticos, do pressuposto de que Fernando Collor nunca esteve plenamente livre para escolher os rumos internacionais do país, sempre o fazendo a partir de constrangimentos estruturais previamente dados (e.g. distribuição de poder - econômico, político ou militar - no sistema internacional e o interesse das grandes potências com relação ao Brasil) e de quadros conceituais ou paradigmáticos que também antecederam sua chegada

\footnotetext{
${ }^{10}$ Melo, Carlos. Collor: o ator e suas circunstâncias. São Paulo: Novo Conceito, 2007.
} 
ao poder (e.g. a integração competitiva, no caso das relações entre Estado e sociedade, ou a autonomia como corolário da política externa universalista herdada de San Tiago Dantas e Araújo Castro).

No entanto, sua decisão consciente de fazer uso sistemático da diplomacia presidencial, sobretudo por meio de viagens internacionais e discursos centrados em questões globais, teve impacto sobre a política externa. No entendimento de Collor, o que estava em jogo na política externa brasileira era, antes de tudo, a credibilidade do país. Essa era a sina do governo Sarney, que ficou para a história como o quinquênio dos mais graves entreveros com os Estados Unidos (que chegaram a nos sancionar em retaliação a contenciosos comerciais), com a comunidade financeira internacional (contra a qual decretamos uma moratória da dívida externa) e com aquelas lideranças que abraçavam, paulatinamente, temáticas como meio ambiente e direitos humanos - a ponto de nos vermos transformados em párias ambientais ou no tratamento das populações indígenas. Somando-se isso a um presidente que, ao fim de seu mandato, não gozava mais de prestígio nem doméstico nem externo, pode-se dizer que o problema mais crítico do Brasil, em matéria de política exterior, era sua imagem internacional. Embora não fosse propriamente de uma questão de poder em sua acepção material, a credibilidade pode ser um mecanismo importante, principalmente para potências médias, para aliviar os constrangimentos estruturais ou, alternativamente, para ampliar a margem de autonomia em algumas questões internacionais.

Não se tratava de uma percepção exclusiva de Collor. As eleições de 1989 foram caracterizadas por uma particularidade, como demonstraremos no capítulo 2 desta tese: virtualmente todos os principais candidatos realizaram viagens ao exterior como parte da agenda de campanha. Ora, num quadro de disputa acirrada, em que a composição do segundo turno foi decidida no olho mecânico, qual o sentido de desperdiçar dias (até mesmo semanas) fora do país, com um eleitorado que não é o seu? Existem várias explicações possíveis. Uma delas tem a ver com a necessidade de reforçar alinhamentos ideológicos a partir de lideranças estrangeiras. Os roteiros dos candidatos, em geral, foram escolhidos com isso em mente: Brizola foi a Paris encontrar-se com François Mitterrand, uma das maiores figuras do socialismo europeu; Lula, além de Paris, foi à União Soviética, à China e aos Estados Unidos, onde se encontrou com líderes do movimento sindical norte-americano; Maluf também foi aos EUA, mas de olho no apoio do ex-presidente Reagan. Havia também uma questão política mais imediata, que se relacionava com a necessidade de suporte de atores internacionais importantes caso qualquer um deles ganhasse a eleição, bem como o desejo pelo apoio doméstico. Diante de um numeroso eleitorado católico, por exemplo, todos os candidatos que 
embarcaram ao exterior realizaram uma parada obrigatória no Vaticano - divulgando, em seguida, uma foto com o popular papa João Paulo II.

Collor, que realizou a mais longa viagem de campanha - três semanas e seis países europeus -, beneficiou-se duplamente desse movimento de "internacionalização" da corrida presidencial. Como não possuía plataforma política clara, muito menos vínculos partidários sólidos, o candidato do PRN pôde moldar sua proposta de inserção internacional de maneira muito mais livre que os demais. Não seria exagero dizer que suas ideias sobre a política externa brasileira foram, ao contrário dos demais concorrentes, plenamente condicionadas pelo sistema internacional, uma vez que buscavam atender às cobranças que o mundo fazia do Brasil. Não à toa, Collor elegeu três prioridades externas na campanha - dívida externa, ecologia e integração regional - que soavam bem, respectivamente, aos credores privados, às potências industrializadas e aos vizinhos latino-americanos, muitos dos quais passando por guinadas liberalizantes semelhantes à brasileira mas, via de regra, bem mais radicais. Embora as propostas de Collor apresentassem um fundo autonomista (na medida em que, obviamente, não estava em jogo a internacionalização da Amazônia ou o pagamento incondicional da dívida), havia uma mudança retórica importante em direção ao Primeiro Mundo, situando o candidato na crista da onda de uma tendência global, por um lado, e latino-americana, por outro. Ao mesmo tempo, no plano doméstico a viagem de Collor à Europa permitiu-lhe construir e reconstruir sua própria identidade política de acordo com as conveniências eleitorais - ora um liberal convicto, ora um social-democrata, ora um socialista moderno.

Foi também no decurso da campanha que Collor cunhou seu próprio conceito de modernização. Dadas as fragilidades de seu discurso, não fica claro se o processo a que o candidato se referia estava mais ligado ao Estado-mínimo de Thatcher e Reagan ou ao Estadoeficiente $^{11}$ da social-democracia europeia. Bandeira eleitoral eficaz, que lhe serviu para traçar uma clara linha entre sua candidatura e a de Lula, no segundo turno, a estratégia da modernização ganha contornos mais específicos após a eleição. A partir dali, o jogo político já demandava a adequação da retórica de campanha aos quadros conceituais já existentes nas burocracias econômica e diplomática - permitindo, no máximo, adaptações pontuais.

É durante as viagens de presidente-eleito que a estratégia de autonomia pela modernização é concebida, embora ainda numa formulação incipiente, que será objeto de análise do capítulo 3. A visita de Collor aos três principais vizinhos sul-americanos (com

\footnotetext{
${ }^{11}$ A esses modelos de relacionamento entre Estado e sociedade, Amado Cervo e Clodoaldo Bueno chamam de "Estado normal", vinculado à matriz de pensamento neoliberal, e "Estado logístico", próprio dos europeus continentais. Ver Cervo, Amado e Bueno, Clodoaldo. História da Política Exterior do Brasil. Brasília: UnB, 2002.
} 
quem formaríamos, mais tarde, o Mercado Comum do Sul) e a nada menos que nove das maiores economias mundiais foi a maneira que o presidente-eleito encontrou de sedimentar a nova imagem do Brasil no mundo, em profundo contraste com aquela legada por José Sarney, bem como de sentir a receptividade de suas propostas em nível global. De manifestações relativamente ingênuas sobre a política externa brasileira que marcaram a campanha, Collor passa a definir, com mais clareza, (1) qual a agenda do Brasil no mundo; e (2) qual a retórica que sustentará essa nova agenda. A ideia de inserção no Primeiro Mundo surge nesse contexto com particular força e agrada aos ouvidos dos interlocutores estrangeiros, a quem são também apresentadas as linhas básicas do plano de estabilização da economia. Os pontos de conflito bilateral são, estrategicamente, deixados em suspenso, mascarados pelo discurso assertivo do novo presidente. Em todo caso, pode-se dizer que, além da questão da credibilidade, outro movimento surge neste período (que, a rigor, é o primeiro período da política externa do governo Collor): ainda sem uma equipe bem definida e cercado de poucos assessores, Collor transfere, intencionalmente, o peso das pressões internacionais - e as responsabilidades da construção da imagem brasileira - para si próprio, o que representa um descolamento do padrão de política externa observado desde 1964, centralizado prioritariamente no Itamaraty.

O segundo período da política externa "collorida", que será coberto ao longo do capítulo 4, compreende o início do governo, da posse em março de 1990 à queda da ministra Zélia Cardoso de Mello, em maio de 1991. Esse interregno, a que Bresser-Pereira chama de tempos heroicos, são aqueles em que o presidente jogou todo seu capital político, acumulado ao longo da campanha e das viagens como eleito, para definir a agenda internacional brasileira de acordo com os interesses nacionais. Ainda mantendo em si a característica de fiador último dos rumos da inserção internacional do país, aumentando o tom da retórica e marcando o período com incontáveis viagens ao exterior, Collor realizou três movimentos importantes que nos ajudam a pensar a ideia de autonomia pela modernização: em primeiro lugar, cercou-se de diplomatas como assessores palacianos, que lhe conferiam credibilidade pessoal e às suas propostas e, no limite, enquadravam-nas nos quadros conceituais da tradição diplomática brasileira; segundo, inflamou o discurso da modernização, que tão bem soava aos parceiros do Primeiro Mundo, mas sempre condicionando-o ao sucesso do programa de estabilização econômica que foi lançado no primeiro dia de governo; por fim, autorizou os dois agentes burocráticos diretamente envolvidos nos entraves da política externa - o Ministério das Relações Exteriores e o Ministério da Economia, sobretudo nas questões de dívida e abertura comercial - a resistir, ao máximo, às pressões sistêmicas contrárias à autonomia brasileira. Modernização na retórica, autonomia na prática. 
O terceiro período da política externa, destacado no capítulo 5, diz respeito ao momento em que ocorre a primeira troca ministerial no coração do processo decisório da política externa: saem Zélia e seus ideais de integração competitiva, com resquícios desenvolvimentistas, entra Marcílio Marques Moreira, ex-embaixador em Washington e um liberal convicto. Sem entrar, aqui, nas múltiplas razões que conduziram ao ocaso da ministra, pode-se dizer que sua queda se deve parcialmente ao fracasso do Brasil em resistir às pressões sobre a dívida externa vindas, sobretudo, dos bancos credores. Um dos sustentáculos que ainda permitiam ao Brasil postergar as negociações da dívida - o apoio político conferido pelo governo norte-americano - havia se esvaído por uma série de motivos ligados à prática autonomista brasileira: da insistência no fortalecimento do Mercosul à recusa do envio de tropas à Guerra do Golfo, da demora na aprovação da liberalização da informática à indecisão quanto ao Tratado de Não-Proliferação, a modernização retórica perdeu rapidamente sua utilidade.

Neste momento, as concessões começam a aparecer: cede-se na questão da dívida, o que abre flancos para derrotas parciais na questão nuclear e também na questão da integração sul-americana, com a assinatura do acordo $4+1$ com os Estados Unidos. O projeto inicial de integração competitiva condicionada à resolução dos problemas econômicos começa a ruir, dando espaço a uma política de viés neoliberal, de abertura muitas vezes incondicional. Como forma de compensar as perdas nas negociações, o presidente - olhando, muito provavelmente, para alguns interlocutores domésticos - passa a abraçar forte retórica terceiro-mundista, crítica e muitas vezes confrontacionista, resgatando uma postura digna do legado universalista de Geisel e seus sucessores. Autonomia na retórica, modernização-forçada - na prática.

Todo esse processo caminha em paralelo à sina de um presidente cada vez mais isolado, sem qualquer apoio político e fracassado nas tentativas de entendimento nacional. A retórica confrontacionista, que atende a alguns anseios domésticos e acaba por prover certo grau (ainda que tênue) de união nacional, vai aos poucos sendo minada pela contínua pressão internacional. A síntese disso, ao longo do terceiro momento, é a tentativa de Collor de propor um novo conceito das relações Estado-sociedade, a que ele próprio chama, inspirado nos trabalhos do diplomata e filósofo José Guilherme Merquior, de social-liberalismo. Digamos que o novo marco conceitual proposto pelo presidente foi a última tentativa, já num quadro de esgarçamento social e político, de realinhar discurso e prática. Para Collor, provou-se tarde demais.

A opção encontrada pelo presidente, que se aplicou não somente ao Itamaraty mas a outras burocracias de Estado, foi a transferência de sua credibilidade pessoal (que já havia 
desaparecido) a figuras de reputação ilibada que assumiram, nos primeiros meses de 1992, alguns postos-chave de primeiro escalão. Em algum sentido, isso havia começado com Marcílio, no ano anterior, embora os propósitos fossem diferentes. Estabeleceu-se, assim, o chamado "ministério dos notáveis", que contou com a substituição de Francisco Rezek, desgastado pelos movimentos da política exterior, por Celso Lafer. Ao fazê-lo, Collor realinha os interesses do governo - que havia intencionalmente descolado a presidência das burocracias - com os do Itamaraty. Naquilo que ainda se poderia resistir, coube aos diplomatas reaver a credibilidade do Brasil e aprofundar a autonomia da política externa brasileira. No auge dos chamados "novos temas" - democracia, direitos humanos, ecologia e dos regimes internacionais erguidos em seu entorno, a política externa brasileira centrou-se no multilateralismo e no aprofundamento da integração sul-americana como forma de projeção internacional. A partir de uma leitura menos rígida de autonomia do que aquela, marcadamente soberanista, que prevalecera até então, autonomia e modernização se fundem numa nova estratégia internacional ${ }^{12}$ por meio da qual o Brasil busca se posicionar na vanguarda da nova agenda global ainda em construção. Autonomia pela modernização será, portanto, o tema do capítulo 6.

\section{Metodologia}

Ao oferecer uma releitura histórica teoricamente orientada, o trabalho aqui empreendido busca identificar "histórias causais relevantes e verificáveis que se sustentem em distintas cadeias de relações causa-efeito, cuja eficácia pode ser demonstrada independentemente de tais histórias" ${ }^{\prime 13}$. Dito de uma outra forma, sequência de fatos e eventos trazida à luz ao longo da tese não sugere a criação de uma relação teórica em si, mas orientase por um conjunto de hipóteses anteriores discutido na literatura sobre política externa brasileira - e ao qual recorreremos, de maneira específica, no próximo capítulo. No limite, quer-se compreender como variáveis causais interagem entre si (forças sistêmicas/apoio societário/rotinas burocráticas/preferências individuais) condicionando a resultante da política externa. Embora, por força de hipótese, coloque-se particular ênfase nas causas estruturais em detrimento da vontade dos agentes, não podemos deixar de sublinhar a complexa interação

\footnotetext{
${ }^{12}$ De que são tributárias as noções posteriores de autonomia pela integração e autonomia pela participação. Ver Fonseca Júnior, Gelson. A Legitimidade e Outras Questões Internacionais. São Paulo: Paz e Terra, 1998; Cepaluni, Gabriel e Vigevani, Tullo. A Política Externa Brasileira: a busca da autonomia, de Sarney a Lula. São Paulo: UNESP, 2011.

${ }^{13}$ Tilly, Charles. "Means and Ends of Comparison in Macrosociology". Comparative Social Research, vol. 16, 1997, p. 48.
} 
que elas estabelecem, levando a resultados distintos ao longo do tempo e em temáticas diferentes.

Além do corte analítico, deve-se chamar a atenção para o substrato empírico que foi trazido à baila para a realização deste trabalho. O texto foi construído a partir de quatro elementos principais: (1) informações obtidas de jornais e revistas da época; (2) documentos diplomáticos oficiais, de distintos graus de confidencialidade; (3) entrevistas com os principais atores da política externa brasileira do período; (4) análises conjunturais, de inclinação acadêmica, publicadas no decurso dos fatos e eventos.

Com relação ao primeiro elemento, buscou-se fazer um levantamento exaustivo das publicações jornalísticas que cobrissem todo o período de 1989, do início da primeira campanha presidencial direta após o regime militar, até fins de 1992, quando do afastamento do presidente da República em função do processo de impedimento a que foi submetido. Dentre os periódicos nacionais, demos preferência àqueles cujo acervo digital está aberto a consultas (pagas ou gratuitas): Folha de São Paulo, O Estado de São Paulo e O Globo. Sempre que possível, também se consultou o Jornal do Brasil, a despeito de uma limitação nos mecanismos digitais de pesquisa. Foram também utilizados alguns jornais estrangeiros, especialmente o The New York Times e algumas edições específicas do Clarín argentino, disponíveis eletronicamente. Além dos fatos extraídos da pesquisa hemerográfica, houve a intenção de aproveitar os comentários de opinião, seja de editoriais ou de articulistas, como forma de situar o debate em seu próprio momento histórico. Ainda que algumas opiniões sejam meramente ilustrativas do tipo de questionamentos que se fazia sobre o Brasil ou o mundo da época, outras dão importantes pistas sobre os rumos da política externa e seus principais constrangimentos domésticos ou internacionais. Por fim, alguns semanários foram utilizados de forma mais pontual, como Veja ou Isto É/Senhor, para complementar informações que se encontravam muitas vezes fragmentadas nos jornais.

Com relação aos documentos oficiais, eles derivam de duas fontes básicas: os arquivos diplomáticos do Ministério das Relações Exteriores, em Brasília, e o acervo disponível na base digital da George Bush Presidential Library and Museum. Os documentos obtidos no Itamaraty, principalmente telegramas (documentos dirigidos de uma representação no exterior para o MRE) e despachos telegráficos (documentos dirigidos do MRE aos postos diplomáticos no exterior), mostraram-se de serventia ambígua: enquanto alguns deles continham informações sensíveis e relevantes à interpretação do período, sua enorme maioria era constituída por documentos "ostensivos", isto é, informações de cunho jornalístico repassadas às embaixadas no exterior, solicitações burocráticas de remoção e promoção, 
realizações de orçamento para eventos ou reformas na estrutura física das embaixadas, etc. Por restrições de tempo e orçamento, não se fez um levantamento exaustivo de toda a documentação, limitando-nos à coleção de telegramas e despachos de 1990 a 1992 de/para as seguintes embaixadas: Washington, Cidade do México, Buenos Aires, Tóquio, Tel Aviv, Moscou. Já os documentos norte-americanos nos permitiram a reconstrução detalhada de encontros e conversas entre Collor, Bush e seus assessores, jogando luz sobre as barganhas e as pressões que orientavam esta relação bilateral em particular.

Para as entrevistas, foram selecionados os personagens mais importantes do período, da perspectiva da política externa brasileira. Todas elas foram estruturadas em torno de questões-chave para o entendimento do período e perguntas mais específicas relativas a episódios pontuais ou ao seu papel na condução do processo. Algumas delas ocorreram em 2011, quando o desenho da tese ainda não havia tomado seu formato atual, de modo que muitas questões levantadas ao longo do texto não foram abordadas nas conversas. Nas demais entrevistas, testou-se mais claramente a tese do trabalho, além de ter-se coletado um conjunto amplo de informações importantes. Por solicitação de alguns, não se transcreveram textualmente passagens de seus depoimentos, de modo que ou se utilizou a citação desidentificada (com a devida concordância do entrevistado) ou se aproveitou o depoimento para a busca de novas informações, para a consolidação de argumentos específicos, sem que isso demandasse comprovação textual. A lista de entrevistados foi a seguinte (por ordem cronológica):

- José Francisco Rezek (Ministro das Relações Exteriores, 1990-1992), 04/05/2011;

- João Santana (Secretário da Administração Federal, 1990-1992), 04/05/2011;

- Marcos Azambuja (Secretário Geral de Política Exterior, 1990-1992), 18/05/2011;

- Gelson Fonseca Júnior (Embaixador, Assessor da Presidência, 1990-1992), 18/05/2011;

- Paulo Tarso Flecha de Lima (Secretário Geral do MRE, 1985-1990), 19/05/2011;

- Fernando Collor de Mello (Presidente da República, 1990-1992), 13/06/2011;

- Celso Lafer (Ministro das Relações Exteriores, 1992), 03/12/2013;

- José Francisco Rezek, entrevistas concedidas ao CPDOC-FGV e conduzidas pelo autor, 24/06 e 02/10/2014;

- Clodoaldo Hugueney (Chefe da Assessoria Internacional do Ministério da Economia, 1990-1991; Chefe do Departamento Econômico do MRE, 1991-1992), 06/10/2014;

- Zélia Cardoso de Mello (Ministra da Economia, 1990-1991), 18/10/2014; 
- Rubens Ricupero (Embaixador do GATT, 1986-1991; Embaixador em Washington, 1991-1994), 30/10/2014.

Além disso, valeu-se de uma série de depoimentos que alguns destes atores (e outras autoridades relevantes) concederam ao Centro de Documentação e Pesquisa da Fundação Getúlio Vargas (CPDOC-FGV), mencionadas ao longo do trabalho e nas referências bibliográficas.

Por fim, o trabalho buscou fazer uso da maior quantidade possível de análises acadêmicas de natureza conjuntural, de modo a compreender não somente as decisões tomadas no período, mas também o seu contexto. Fez-se necessário recorrer a esse expediente para evitar interpretações anacrônicas e leituras retrospectivas em que o conhecimento de todo o processo comprometesse o entendimento das limitações da racionalidade dos atores políticos. Os textos consagrados sobre o período foram, naturalmente, explorados em sua plenitude. 


\section{CAPÍTULO 1}

\section{A “economia política da política externa brasileira": pressupostos e desdobramentos}

Tendo a política externa do governo Collor como objeto de investigação, e diante das interpretações correntes a respeito do período, enunciadas brevemente na introdução, o problema central que este trabalho busca enfrentar é a questão da mudança na política externa de um determinado país, a partir de uma abordagem de escolha racional. Propõe-se, para tanto, uma síntese analítica entre os trabalhos de Charles Hermann ${ }^{14}$, que lida de maneira específica com as mudanças de percurso na política externa, e de Maria Regina Soares de Lima, que explora as possibilidades da política externa brasileira na década de 1980 sob a ótica da ação coletiva. A união de ambas as perspectivas faz-se necessária na medida em que, muito embora Lima seja razoavelmente bem-sucedida em divisar um esquema analítico acerca das estratégias internacionais da semiperiferia à luz do caso brasileiro, sua tipificação não nos parece exaustiva ${ }^{15}$. A discussão realizada por Hermann, nesse sentido, traz um conjunto de instrumentos que, adicionados às categorias propostas por Lima, abre novos caminhos na compreensão das transformações brasileiras na passagem da década de 1980.

$\mathrm{O}$ artigo de Lima, fruto de tese de doutoramento defendida em $1986^{16}$, enuncia uma proposta de análise do que a própria autora denomina "economia política da política externa brasileira". O ponto de partida de seu argumento passa pela constatação de que a ampliação do espaço de expansão capitalista, ao longo da década de 1970, conduziu à emergência de países semi-industrializados na periferia do capitalismo. Tais nações, ao apresentarem um "alto grau de integração comercial, industrial e financeira à economia mundial", atuariam no âmbito da política internacional a partir de parâmetros próprios de ação. Entre os rótulos mais costumeiros usados para identificar este grupo de países, destacam-se potência média e potência emergente ${ }^{17}$, que empregaremos de maneira intercambiável ao longo de todo o texto.

Três foram as perspectivas que buscaram dar conta da inserção internacional das potências emergentes. A primeira delas destaca a existência de países industrializados no Terceiro Mundo como fruto da inserção semiperiférica na divisão internacional do trabalho,

\footnotetext{
${ }^{14}$ Hermann, Charles. "Changing Course: when governments choose to redirect foreign policy”. International Studies Quarterly, 34, 1990.

${ }^{15}$ Esta percepção decorre de um intercâmbio de ideias entre o autor e o Prof. Amâncio Jorge de Oliveira, a quem agradeço nominalmente.

${ }^{16}$ Recentemente publicada pela Fundação Alexandre de Gusmão. Lima, Maria Regina Soares de. The Political Economy of Brazilian Foreign Policy. Brasília: FUNAG, 2014.

17 Lima, Maria Regina Soares de. “A Economia Política da Política Externa Brasileira”. Contexto Internacional, vol. 12, ano 6, 1990, p. 7.
} 
na esteira dos argumentos de Galtung e Wallerstein ${ }^{18}$. Nessa ótica, os atores semiperiféricos, ou emergentes, operariam como centros de hegemonia regional - portando-se, assim, como "intermediários" dos interesses estratégicos, políticos e econômicos das potências centrais numa determinada região. Exercem, pois, uma espécie de subimperialismo regional, arranjo no qual os Estados centrais pagariam recompensas materais - de natureza econômico-militar - em troca dessa transferência de custos no exercício da dominação descentralizada. Dentro dessa lógica, os países semiperiféricos apresentam duas características centrais: estabelecem com os vizinhos uma relação imperialista, mas ligam-se por simbiose com os centros capitalistas e suas elites. Elas condicionariam, desta forma, uma espécie de padrão uniforme do comportamento internacional das potências emergentes ${ }^{19}$.

Se a perspectiva do subimperialismo pode ser entendida, como sustenta Galtung, no contexto do declínio da potência hegemônica - que precisaria, a partir daí, partilhar custos e responsabilidade na periferia -, o segundo esquema disposto pela autora, chamado neorrealismo complexo, inverte essa relação. De acordo com essa ótica, o ocaso dos Estados Unidos não estaria relacionado ao surgimento de um grupo de mediadores (ou “atravessadores") na periferia, mas sim à emergência de pólos autônomos de poder de médio porte. Países semiperiféricos, dotados de ampla base industrial e recursos materiais de poder, como o Brasil e a Índia desde a década de 1970, seriam capazes de perseguir interesses próprios no contexto regional, ou mesmo, eventualmente, no plano global. Nações centrais mas não-hegemônicas, como o Japão e a Alemanha Ocidental, também ampliariam suas possibilidades de iniciativa externa autônoma. Em ambos os casos, os países de médio porte apresentariam comportamento competitivo, muitas vezes unilateral e desalinhado dos centros de poder, no contexto de um sistema internacional flexível e permissível à ascensão hierárquica dos Estados $^{20}$.

Por fim, a perspectiva do carona destaca os conflitos comerciais entre os países recém-industrializados (newly industrialized countries, NICs) e aqueles industrializados, no tocante à participação de ambos os grupos na exportação mundial de manufaturados. Como os NICs adotaram, historicamente, uma estratégia de crescimento baseada nas exportações, sua emergência (que coincidiu com um período de baixa atividade econômica e alta do petróleo, após a crise de 1973) acarretou um desequilíbrio na estrutura do comércio internacional, originalmente centrada nos centros capitalistas avançados. Ainda assim, os países recém-

\footnotetext{
${ }^{18}$ Galtung e Wallerstein apud Lima, 1990, p. 7.

${ }^{19}$ Lima, 1990, p. 8.

${ }^{20}$ Lima, 1990, pp. 8-9.
} 
industrializados foram capazes de beneficiar-se passivamente das vantagens tarifárias derivadas do regime de livre comércio, sem arcar com os altos custos de mantê-lo - pegando carona, portanto, no movimento ascendente de interdependência da economia mundial. Destarte, os NICs situam-se numa espécie de "área cinzenta" da clivagem Norte-Sul, não alinhados aos interesses dos países do norte (visto que são, no limite, concorrentes), mas tampouco desejosos de alterações profundas na ordem econômica internacional, como almeja, de forma geral, o Terceiro Mundo ${ }^{21}$.

Do ponto de vista metodológico, as três perspectivas resenhadas pela autora oferecem um aspecto particularmente promissor, o de "livrar o analista dos constrangimentos da geografia, permitindo-lhe focalizar comportamentos peculiares dos Estados semiindustrializados, quais sejam, aliado especial, potência emergente e carona predatório" ${ }^{22}$. Por outro lado, cada uma delas atribui um tipo específico (e fixo) de conduta àqueles países, mutuamente excludentes entre si, posto que partem de concepções distintas a respeito dos indicadores de poder real no sistema internacional. Ao oferecerem esquemas explicativos estanques, mostram-se particularmente deficientes diante de condutas ambíguas dos países recém-industrializados, que ora se alinham aos interesses da potência hegemônica (como foi o caso, por exemplo, do Brasil de Costa e Silva e Juracy Magalhães), ora perseguem o caminho da autonomia (como bem demonstrado pelo pragmatismo responsável e ecumênico de Geisel e Azeredo da Silveira), variando estratégias de inserção internacional em diferentes áreas temáticas e em distintos momentos no tempo. Com efeito,

\footnotetext{
"[a] evolução da política externa e do papel internacional do Brasil em anos recentes tratou de desmentir as implicações políticas derivadas quer do esquema subimperialista, quer do modelo de potência emergente. Uma de suas fragilidades reside na antinomia que estabelecem entre subordinação/dependência, por um lado, e autonomia, por outro, vistos como fenômenos excludentes, constitutivos da natureza da política externa" ${ }^{\text {23 }}$.
}

A autora oferece, assim, um esquema de análise que parte da ideia de que as relações internacionais dos países semiperiféricos são marcadas tanto por autonomia quanto por dependência. Afinal, se considerarmos que tal categoria de Estados, por encontrarem-se em um estágio mais avançado do seu processo de industrialização e de integração à economia internacional, possuem um leque mais amplo de objetivos estratégicos e escopo de interesses, não podemos deixar de considerar que seus padrões de comportamento sejam igualmente

\footnotetext{
${ }^{21}$ Lima, 1990, p. 9.

${ }^{22}$ Lima, 1990, p. 10.

${ }^{23}$ Lima, 1990, p 10.
} 
diversos. Isso se torna visível, sobretudo, diante da observação de uma característica singular às economias da semiperiferia: são poderosas, de um lado, se levarmos em conta a distribuição, em termos abrangentes, de recursos internacionais de poder; ao mesmo tempo, padecem das distorções que caracterizam todo o processo de industrialização periférica, apresentando um alto grau de heterogeneidade estrutural, que se traduz, por exemplo, em desequilíbrios de produtividade e desenvolvimento tecnológico. Desta forma, a perspectiva que se teria em termos agregados do poder - apropriada pelos teóricos neorrealistas como uma vantagem sistêmica dos emergentes - não se concretiza ao desaglutinarmos os indicadores de poder, o que pode revelar vulnerabilidades em determinadas áreas temáticas. Por isso mesmo, "é necessário que a avaliação das capacidades leve em conta questões de escopo, peso e âmbito do poder",24.

Pois bem, diante do quadro apresentado acima, o próximo passo dado por Lima é oferecer um esquema analítico que busque dar conta, de maneira mais nuançada, do comportamento internacional das nações emergentes. Seu pano de fundo é o dilema da ação coletiva - que pressupõe a racionalidade dos atores - aplicado à política internacional. $\mathrm{O}$ argumento pode ser disposto da seguinte maneira: para qualquer Estado, há dois padrões básicos de ação, o unilateral, "em que o país está disposto a arcar com todas as suas possíveis consequências, ainda que estas possam afetar negativamente outros países", ou o multilateral, que se refere "a ações empreendidas para a consecução de objetivos comuns a um grupo de países" ${ }^{25}$. Na busca de bens coletivos, seguindo a lógica da abordagem da estabilidade hegemônica, a expectativa é que os países grandes optem pela estratégia da provisão do bem público - unilateralmente ou por meio da criação de um regime internacional - enquanto os pequenos, por outro lado, adotariam o comportamento do "carona" com vistas a beneficiar-se com os menores custos. Como forma de lidar com os caronas, o país com maiores recursos (país A) poderá ou conceder incentivos seletivos positivos, como bens privados, ao menor (país B) ou coagi-lo a participar do regime, sob ameaça de privá-lo do acesso a certos mercados, produtos estratégicos ou ajuda externa. Quando a natureza do bem público ofertado por A torne inviável a exclusão dos não-contribuintes do benefício produzido, a estratégia do “carona" por parte do país B prevalecerá ${ }^{26}$. Esquematicamente, a gama de padrões de ação de países A e B, numa determinada área temática, pode ser estruturada da seguinte maneira:

\footnotetext{
${ }^{24}$ Lima, 1990, p. 11.

${ }^{25}$ Ibid, p. 16)

${ }^{26}$ Idem.
} 
I

País A

IV

País B
II

Incentivos Positivos

(oferece)

$\mathrm{V}$

Incentivos Positivos

(recebe)
III

Coerção

(exerce)

VI

Coerção

(sofre)

Fonte: Lima,1990, p. 16

Diante de um contexto de multipolaridade emergente em certos temas, no qual o bem público não mais pode ser provido por uma só potência, surge um terceiro grupo de países (de tipo C) - justamente os semiperiféricos ou "potências médias" - que exibem, simultaneamente, os padrões de comportamento típicos de A e B. Desta forma, seria possível atribuir cinco modalidades de estratégias externas às nações semiperiféricas, considerando-se a tipificação exposta acima: (a) a ação unilateral, "na qual são desconsiderados eventuais custos advindos dos efeitos desta sobre terceiros países"; (b) comportamento de "carona", em que se opta por não arcar com os custos da provisão do bem público; (c) estratégia de hegemonia, na qual o país utiliza-se de incentivos positivos e negativos com relação a terceiros para beneficiar-se; (d) ação de liderança, em que o país busca organizar a ação coletiva (em geral pela via multilateral) com vistas a benefícios que podem ser apropriados individualmente; (e) reação, em que, "por força de instrumentos coercitivos manipulados por outros Estados, o país adere às regras do jogo em uma determinada área temática" ${ }^{\text {27 }}$.

Já se exaltou aqui o sucesso obtido pela autora em analisar determinados aspectos do que ela própria chama de "economia política da política externa brasileira". Não obstante, acreditamos ser possível expandir sua tipificação, somando a ela determinados padrões de comportamento que não foram contemplados, e também aprofundando-a em alguns aspectos. Preocupa-nos, em particular, três questões, a partir das quais as críticas serão tecidas e que servirão como base para uma proposta ampliada. A primeira delas é a questão da mudança. Muito embora o trabalho contemple as oscilações no comportamento brasileiro em certas áreas temáticas, como por exemplo em sua análise a respeito da questão da Bacia do Prata, a autora não se dedica a explicar por que as estratégias mudam ao longo do tempo. Nesse sentido, falar em transformações no balanço entre custos e benefícios de uma ação soa demasiadamente simplificador, caso não se jogue luz sobre a geratriz dessas transformações, que certamente podem ser encontradas na dimensão estrutural do sistema internacional, mas não se limitam a ela. Em outras palavras, uma limitação observada do trabalho em tela reside

\footnotetext{
${ }^{27}$ Lima, 1990, pp. 17-18.
} 
em não tornar endógena ao modelo analítico a questão da mudança, relacionando-a sempre a fatores exógenos, sistêmicos, sem buscar nos diversos elementos do plano doméstico variáveis explicativas.

Em segundo lugar, o texto de Lima evidencia uma opção consciente de não tratar de relações simétricas entre Estados, ou seja, de circunstâncias em que interagem dois ou mais países com capacidades similares de poder, sejam elas econômicas ou militares. Parte-se, nesse sentido, da ideia de que toda interação entre dois Estados (ou grupos deles) envolve uma parte mais poderosa e outra mais frágil, dentro de uma área temática ${ }^{28}$. Essa assertiva é problemática por duas razões. A primeira delas é que, ao passo que o modelo analítico proposto mostra-se útil para explicar relações patentemente assimétricas (como Brasil e Paraguai, ou Estados Unidos e Brasil), a clareza se perde quando se fala da relação entre dois semiperiféricos, como entre nosso país e a Índia ou, em algumas conjunturas singulares, a Argentina. A inclusão de tipos que contemplem relações simétricas nos parece particularmente útil no caso brasileiro, iluminando processos pelos quais passa o Brasil na década de oitenta, como a integração regional. Esse ponto nos leva à segunda constatação a respeito da fragilidade de postular relações permanentemente assimétricas: como observado no esquema apresentado pela autora, não há espaço para relações genuinamente cooperativas - nem mesmo aquelas em que a cooperação atenda a um interesse estratégico patente, como no caso de uma aliança em defesa de um bem coletivo. Em situações de assimetria, a cooperação sempre está condicionada a algum tipo de oferta intra-aliança, seja de incentivos positivos ou ameaças críveis, para além dos benefícios engendrados pela formação da aliança per se. Não é o caso de cooperação horizontal, simétrica, que se aproxima de um jogo de soma positiva.

Finalmente, muito embora o texto de Lima convide a uma formalização da análise, nos termos da teoria dos jogos, ela é tratada de maneira muito rudimentar e não consta de maneira expressa no argumento. Não há, contudo, qualquer problematização das preferências dos atores, sendo elas tomadas como exógenas ao modelo, o que aproxima o empreendimento da autora das análises neorrealistas mais refinadas, capazes de capturar, mesmo sob a ótica do realismo, a ambiguidade comportamental dos atores diante de instituições ou regimes internacionais. É necessário notar, por outro lado, que a opção por um empreendimento intelectual que se distancia da análise de política externa no seu sentido estrito, isto é, que não

\footnotetext{
${ }^{28}$ Lima (1990) diz querer estabelecer "a gama de padrões prováveis de comportamento para dois tipos de países hipotéticos $\mathrm{A}$ e $\mathrm{B}$, quando A detém uma preponderância de recursos econômicos em face de B", (p. 16, grifo nosso).
} 
avance na consideração da diversidade de interesses estratégicos (no plano doméstico ou na interação entre os níveis analíticos) para além da clássica rubrica "maximização de preferências" obscurece certas dimensões cruciais para se compreender, por exemplo, a mudança de orientação internacional.

Ora, se a autora parte da premissa de que os atores são racionais e de que suas preferências são condicionadas - e não somente constrangidas - pela distribuição de recursos de poder no sistema internacional, ainda que variem de acordo com a issue-area e as arenas de interação, duas considerações estariam em ordem. Primeiro: o Estado tem que ser pensado como um bloco monolítico de interesses, cujas ações no plano internacional são perfeitamente coerentes ao longo do tempo (mesmo que as estratégias mudem face aos distintos espaços de interação $^{29}$ ) se não houver movimentos estruturais significativos no sistema internacional. Quer dizer, salvo em períodos nos quais se observa uma transformação na ordem internacional - como foi o caso da "multipolarização"/“oligopolização" das relações econômicas internacionais no início da década de 1970 -, as preferências se conservam no tempo. Mudanças na conduta de um determinado Estado, portanto, ocorreriam ou quando ele se vê constrangido pela emergência de uma nova ordem (o que, em política internacional, costuma ocorrer em ciclos de longue durée, nos termos braudelianos) ou quando ele mesmo altera suas condições de recursos de poder a ponto de promover uma alteração da ordem vigente. Em nenhum dos casos, trata-se de algo facilmente capturável em recortes curtos, obrigando o analista a debruçar-se sobre o quadro mais amplo de acontecimentos dentro do qual se insere o Estado em questão.

Há, adicionalmente, o problema da formação das preferências. Não acreditamos que o interesse do Estado seja exclusivamente fruto da distribuição de poder no sistema, como sugere a literatura de corte neorrealista ${ }^{30}$, sendo também informado (ou ao menos mitigado) por constrangimentos domésticos. A esse respeito, a autora adota uma posição ambígua. Ao construir um modelo inspirado pelas teses da estabilidade hegemônica e do realismo político, parte da ideia (à qual a sub-área de APE é infensa) do Estado como "caixa preta". De fato, todo o argumento que conduz à categorização dos padrões de ação dos países semiperiféricos parece sustentar-se em cima desse pressuposto. A própria análise da economia política da PEB, empreendida por Lima, não problematiza o nível doméstico, seja na dimensão societária

\footnotetext{
${ }^{29}$ Para uma explicação detalhada sobre a diferença entre preferências e estratégias, ver Frieden, Jeffry. "Actors And Preferences In International Relations". In: LAKE, David A e POWELL, Robert. Strategic Choice And International Relations. NY: Princeton University Press, 1999..

${ }^{30}$ (cf. Waltz, Kenneth. Theory of International Politics. New York: McGraw Hill, 1979; Mearsheimer, John J. The False Promise of International Institutions. International Security, vol. 19, no. 3, 1995.
} 
ou burocrática. Ao mesmo tempo, a autora assume como objetivo manifesto de seu trabalho sugerir, para fins analíticos, “diferentes padrões de ação externa ou estratégias resultantes da estrutura de incentivos em determinadas áreas temáticas, dos recursos específicos de poder nessas áreas e dos constrangimentos domésticos" ${ }^{31}$, sobre os quais não tece quaisquer comentários adicionais.

A crítica realizada nas páginas anteriores nos servirá de base para a proposição de um modelo alternativo de análise, que conserve os elementos básicos propostos por Lima (1990) e expanda, ao mesmo tempo, as possibilidades de ação dos Estados semiperiféricos. Também será dada uma palavra sobre a formação de preferências, com vistas a incorporar algumas questões do plano doméstico. Para isso, a contribuição de Hermann (1990) será fundamental. Discutiremos os principais elementos do modelo na próxima seção.

\subsection{Uma nova proposta para a análise da política externa brasileira}

A construção analítica proposta por Maria Regina Soares de Lima é extremamente frutífera, como foi dito anteriormente, mas carece de alguns elementos adicionais, tanto em termos de sua abrangência (os tipos de padrão de comportamento que contempla) quanto de sua profundidade (os fatores causais que conduzem à formação de preferências e a eventuais mudanças de posicionamento internacional). A questão da abrangência parece ser mais simples, e pode ser resolvida com o acréscimo de duas novas dimensões. A primeira delas é a credibilidade, especialmente no que se refere à disposição de ameaças de coerção por parte do país A sobre o país B. Quando a credibilidade de uma ameaça é baixa, a ação do Estado dominante pode não surtir o efeito desejado sobre sua contraparte mais fraca. Embora a autora toque no assunto, ela só o faz de maneira tópica, e não explora o tipo de resultado em que incorre uma coerção pouco crível. Adicionaríamos, portanto, uma quarta categoria aos padrões de comportamento dispostos, em que a ação coercitiva de A não interfere sobre B de maneira a mudar seu comportamento:

$\begin{array}{ccccc} & \text { I } & \text { II } & \text { III } & \text { IV } \\ \text { País A } & \text { Ação Unilateral } & \text { Incentivos Positivos } & \text { Coerção } & \text { Coerção (s/credibilidade) } \\ & & \text { (oferece) } & \text { (exerce) } & \text { VIII } \\ \text { País B } & \text { V } & \text { VI } & \text { VII } & \text { VIII } \\ & \text { Carona } & \text { Incentivos Positivos } & \text { Coerção } & \text { Sem efeito } \\ & & \text { (recebe) } & \text { (sofre) } & \end{array}$

${ }^{31}$ Lima, 1990, p. 10, grifo nosso. 
Quais os fatores que determinam o grau de credibilidade, por assim dizer, de uma determinada ameaça? Oportunamente, tomaremos emprestado da análise de Odell ${ }^{32}$, que trata das relações Brasil-Estados Unidos na questão da informática, duas variáveis que parecem ser satisfatórias para o modelo proposto: a especificidade da ameaça, isto é, se a forma como o país A busca exercer seus instrumentos coercitivos é exposta ao país-alvo B em seus detalhes ou se é apresentada de maneira vaga ou inespecífica. Pode-se dizer, seguramente, que quanto maior a especificidade de uma ação coercitiva, mais crível ela se torna. Este, no entanto, é somente um lado da questão. Outro fator que impacta sobre a credibilidade da ameaça, nesse sentido, é a unidade dos atores no nível doméstico (de ambos os lados, mas em particular no país A) em torno das medidas a serem tomadas. Isto é, se estivermos lidando com países democráticos e/ou nos quais há instâncias de veto ${ }^{33}$ ou necessidade de ratificação no nível congressual $^{34}$, a ausência de consenso entre os atores políticos que participam do processo decisório torna a ameaça menos crível, num jogo de informação completa ou no qual os atores tenham relativo acesso ao que se passa do outro lado.

$\mathrm{O}$ argumento de Odell, inclusive, traz uma análise comparada entre as pressões comerciais exercidas pelos Estados Unidos sobre o Brasil e a Comunidade Europeia, à mesma época, para ilustrar a ideia de credibilidade da ameaça. De acordo com o autor, embora o governo brasileiro tivesse, a princípio, muito menos condições de resistir à coerção exercida pela administração Reagan que o bloco dos países europeus, a ameaça norte-americana surtiu efeito sobre os últimos, gerando a mudança de comportamento desejada, ao passo que não afetou a reserva de informática brasileira, objeto do contencioso bilateral. A resposta, segundo Odell, está justamente nas duas variáveis descritas acima: a coerção sobre o bloco europeu foi bem-definida, no tocante às retaliações que seriam dispostas, e consensual, no sentido de que Executivo e Legislativo acordavam quanto aos termos das medidas e ao teor da retórica. No caso da Lei da Informática, as ameaças foram inespecíficas e sabidamente não contavam com o apoio irrestrito nem do Congresso, nem mesmo das grandes empresas de informática, algumas das quais poderiam ver sua situação deteriorada no mercado brasileiro após a aplicação de sanções. Este ponto será explorado adiante, quando também faremos uma discussão mais aprofundada sobre o papel dos atores domésticos na determinação das estratégias e dos payoffs.

\footnotetext{
${ }^{32}$ Odell, John. "International Threats and Internal Politics: Brazil, the European Community, and the United States, 1985-1987”. In: Putnam, Robert et al. (org.). Double-Edged Diplomacy. Berkeley: University of California Press, 1993.

${ }^{33}$ Tsebelis, George. Veto Players: How Political Institutions Work. NY: Russell Sage, 2002.

${ }^{34}$ Putnam, Robert. "Diplomacy and Domestic Politics: the logic of two-level games". International Organization, vol. 42, no. 3, 1988.
} 
Uma última palavra sobre credibilidade das ameaças. Mesmo que se tenha falado em grau de credibilidade, na categorização realizada acima a variável é tratada como binária, quer dizer, ou há credibilidade (neste caso, trata-se da coerção normalmente aplicada por A e sofrida por B) ou não há, no caso da qual não haverá efeito sobre o país B. Trata-se de uma questão de difícil operacionalização, pois bem se sabe que mesmo as ameaças com baixa credibilidade podem causar fissuras no consenso doméstico do país $\mathrm{B}$, minando, ao longo do tempo (mas num prazo desconhecido), sua capacidade de resistir à coerção. Para fins analíticos, contudo, acreditamos que a simplificação das categorias dispostas não compromete o argumento.

Um segundo ponto no que diz respeito à abrangência das categorias tem a ver com quem é o first-mover no jogo estratégico. O modelo de Lima somente contempla situações em que o país $\mathrm{A}$, mais poderoso, atua sobre o $\mathrm{B}$, mais frágil, no contexto da provisão de um bem público. Dito de outra maneira, A sempre faria o primeiro movimento sobre B, cabendo ao lado fraco, nessa interação estratégica, capacidade exclusivamente reativa. A própria autora chega a um paradoxo no decorrer de sua análise, quando explora as implicações da política nuclear brasileira:

\footnotetext{
“A decisão brasileira de alcançar auto-suficiência na área nuclear, por meio do acordo com a República Federal da Alemanha, em 1975, enquadra-se na definição aqui adotada de comportamento unilateral, no sentido de que o país está disposto a arcar com as consequiências de uma iniciativa sua no plano externo, ainda que esta possa afetar negativamente um país mais poderoso" 35 .
}

Ora, se no modelo por ela proposto o país A sempre é o primeiro a jogar, como enquadrar, então, a gama de circunstâncias em que, nos termos da própria autora, o país semiperiférico inclina o pêndulo em direção à sua autonomia? Este tipo de jogo estratégico sempre é iniciado com uma ação por parte de $\mathrm{B}$, que é ao mesmo tempo o país emergente e a parte mais frágil da interação. A jogada pode ser unilateral, quando se decide arcar integralmente com os custos e benefícios da decisão, ou multilateral, quando o país B decide recorrer a seus pares (formando coalizões) ou a espaços multilaterais (como a Assembleia Geral das Nações Unidas ou a Organização Mundial do Comércio) para alcançar seus objetivos. Para fins de análise, trataremos somente das ações unilaterais dos países semiperiféricos com relação a alguma potência. Trata-se, naturalmente, de um jogo de soma zero, em que, no contexto da distribuição de recursos de poder internacionais, o crescimento relativo de B implica a perda de espaços de atuação por parte de A. As outras possíveis 
jogadas (oferecer incentivos seletivos positivos ou fazer uso de ameaças) não fazem sentido, a princípio, diante do fato de que o país $B$, no caso, não oferta o bem coletivo e não necessitaria, a rigor, coibir o comportamento de "carona".

Pois bem, feita a jogada inicial, o país mais forte A pode reagir de três diferentes maneiras: (1) quando os custos de uma eventual reação superam as perdas esperadas, a jogada de B não surte efeito sobre A. Com o perdão da aproximação histórica, é possível considerar as relações entre a Alemanha e as potências europeias (Inglaterra e França) entre 1933 e 1937 dentro deste quadro. Mesmo diante de ações unilaterais de uma potência emergente que aparentavam mudar o equilíbrio de poder continental, os grandes da Europa optaram por não reagir às investidas de Hitler, concedendo-lhe importantes ganhos estratégicos ao realizarem a política do appeasement; (2) quando a assimetria de poder é grande o bastante para sustentar uma ameaça crível dentro de uma determinada área temática, o país A exerce a coerção/retaliação como forma de impedir a ação unilateral de B. As sanções econômicas impostas pelos Estados Unidos sobre o Irã, diante das tentativas do regime islâmico em perseguir uma política nuclear alegadamente ofensiva, podem ser compreendidas nesse prisma $^{36}$; (3) quando o custo da ameaça é alto, mas também o é o custo da inação, seja porque as perdas ocasionadas pela ação unilateral de B são altas e/ou porque a retaliação tem baixa credibilidade ou eficácia, o país A pode optar pela estratégia de barganha. Essa foi a conduta do governo Reagan com relação ao Brasil no tocante à reserva de mercado da informática, de fins da década de 1970 até setembro de 1985, quando os Estados Unidos, diante da recusa brasileira em negociar, adotaram as sanções comerciais como forma de penalizar as práticas do governo brasileiro. Podemos dispor esquematicamente os três padrões de ação de A e B (mantidas as denominações originais), em que o país semiperiférico B é o first-mover com relação à potência $\mathrm{A}$.

I

País B

País A
Unilateral/Multilateral

IV

Sem efeito
II

Unilateral

$\mathrm{V}$

Retaliação
III

Unilateral/Multilateral

VI

Barganha

Deve-se, igualmente, conferir uma dimensão de profundidade ao esquema analítico. Faremos, para tanto, uma discussão sobre preferências. Torná-las endógenas ao modelo,

\footnotetext{
${ }^{36}$ A coerção, é importante frisar, pode transformar-se numa ação violenta por parte de A, como foram os casos, por exemplo, da Guerra das Malvinas, em que a Inglaterra valeu-se da guerra como instrumento de força, ou da Guerra do Golfo, em 1990, diante da violação, por parte de Saddam Hussein, da soberania kuwaitiana.
} 
incorporando variáveis de cunho doméstico, não é necessariamente incompatível com os princípios da escolha racional. O Estado, para fins analíticos, continua detendo o monopólio da ação internacional, e interage com seus pares em busca da maximização de seu poder. Ressalta-se, contudo, que (1) os recursos de poder são situacionalmente específicos ${ }^{37}$, isto é, as capacidades e vulnerabilidades de um país podem variar em função da área temática na qual a interação ocorre; (2) a forma como o Estado dispõe suas preferências ou, melhor dizendo, atribui valor aos resultados (outcomes) de uma interação, pode variar ao longo do tempo. Eis uma diferença fundamental com relação ao modelo já exposto: enquanto Lima (1990) argumenta que as estratégias de um país semiperiférico podem mudar com vistas a maximizar seu benefício numa dada relação, postulamos aqui que, além das estratégias, o próprio payoff relativo às preferências é variável.

A variação no valor do payoff significa que, em dois pontos distintos no tempo, o ganho atribuído a uma escolha estratégica dentro de um determinado jogo pode mudar. Esse ponto é central para entendermos, por exemplo, situações em que se mudam os objetivos da política externa, e não somente os caminhos perseguidos na consecução daqueles. Note-se que trabalhamos com um conceito maleável de interesse nacional: ainda que não abandone a premissa da racionalidade do Estado, imputa a ele percepções mutáveis ao longo do tempo. Qualquer análise de política externa, portanto, deve definir com clareza as preferências do(s) Estado(s) e seu payoff no recorte em questão.

Um passo adicional é compreender as causas da mudança de preferências no tempo, no contexto de uma interação estratégica. Aqui, faz-se necessário avançar naquilo que Lima deixa para trás: a consideração sobre as variáveis domésticas e a forma como elas constrangem ou impactam a ação de um Estado no plano internacional. Para tanto, a contribuição de Charles Hermann mostra-se útil, não só porque se debruça sobre o problema da mudança de maneira específica, mas também ao oferecer uma análise detalhada a respeito dos diversos níveis de análise que impactam sobre a produção de política externa. De acordo com o autor, pode-se pensar em quatro diferentes graus de mudança que acometem a política exterior de um país, a saber:

(1) Mudanças de ajuste: são aquelas que ocorrem no nível do esforço (se maior ou menor) e/ou no escopo dos recipientes da ação (quando se refina, por exemplo, o grupo de alvos de determinada política);

\footnotetext{
${ }^{37}$ Cf. Lima, 1990, p. 11.
} 
(2) Mudanças programáticas: ocorrem nos métodos ou meios pelos quais se aborda o objetivo ou problema. Se compararmo-nas às mudanças de ajuste, que tendem a ser quantitativas, as variações programáticas são qualitativas e geralmente envolvem novos instrumentos de gestão (se a negociação der lugar à coerção militar, por exemplo). Nos termos utilizados neste trabalho, podem ser pensadas como mudanças de estratégia;

(3) Mudanças de problema/objetivo: há a substituição ou abandono do problema ou objetivo inicial com o qual lidava o país [em uma determinada área temática]. Equivale a uma mudança de preferências, caso a alteração nos payoffs conduza a um novo ordenamento de interesses;

(4) Mudanças de orientação internacional: envolve um redirecionamento sensível da posição do país com relação às relações internacionais em geral. Impacta, assim, sobre um amplo conjunto de preferências, temas e estratégias. Trata-se da modalidade mais extrema de mudança de política externa ${ }^{38}$.

Além da categorização dos tipos de mudanças, o valor da contribuição de Hermann está em identificar as condições nas quais as transformações ocorrem. $\mathrm{O}$ autor trabalha com quatro fontes de mudança, a saber: a liderança, a burocracia, as reestruturações domésticas e os choques externos. No caso brasileiro, todas essas variáveis interagem entre si, embora de maneiras distintas no tempo e com diferentes intensidades. As formas como as variáveis domésticas (liderança/sociedade/burocracia) podem afetar a inserção internacional de um país merecem um comentário. Em linhas sumárias, pode-se dizer que o impacto doméstico sobre a política externa possui três dimensões: (1) o grau de institucionalização, ou o grau de engajamento do governo com uma determinada política ou ação; (2) o grau de apoio, ou a medida na qual os atores domésticos apoiam, são indiferentes, ou opõem-se à política; (3) o grau de saliência, ou a importância do tema em questão na disputa por poder doméstico ${ }^{39}$. A busca pela autonomia na política externa, tema que trataremos adiante, pode ser entendida como um comportamento altamente institucionalizado por parte do Ministério das Relações Exteriores, encontrando ressonância nos setores domésticos. Temas centrais à agenda

\footnotetext{
${ }^{38}$ Hermann, 1990, p. 5.

${ }^{39}$ Idem, p. 7.
} 
internacional brasileira na virada da década de 1980 acabaram sofrendo mudanças em função de graus distintos de apoio societário. A reserva de mercado da informática, por exemplo, perdeu institucionalização ao longo do tempo, em grande medida em função da redução de seu apoio por parte dos diversos agentes econômicos ao fim da década de 1980. A liberalização comercial, apesar da baixa institucionalização, contava com crescente apoio societário e tornou-se mais saliente na medida em que a crise brasileira cindia o interesse dos empresários e governo a respeito das medidas protecionistas. Ao cabo do mandato de Sarney, o próprio governo viu-se impelido a adotar medidas liberalizantes no plano econômico, em função das transformações observadas no seio da sociedade nos anos anteriores.

\subsection{Teses sobre a politica externa do governo Collor ${ }^{40}$}

Nada se compara, contudo, com o grau de mudança observado com a chegada de Fernando Collor de Mello ao poder. O governo Collor de Mello marcou a evolução da política externa brasileira por representar, antes de tudo, a ruptura de um consenso "nacionaldesenvolvimentista” iniciado a partir dos anos 1970, durante o governo Geisel ${ }^{41}$. A principal característica desta ruptura seria a adoção do neoliberalismo como modelo de gestão macroeconômica, bem como um realinhamento internacional que permitisse levar a cabo o Consenso de Washington. Nesse sentido, a agenda internacional brasileira que emergia com a eleição do presidente Collor construíra-se em torno de três grandes linhas de ação, quais sejam, (1) a adequação do país aos novos temas e dinâmicas da "nova" ordem internacional; (2) a construção de uma agenda positiva com os Estados Unidos, em contrapartida às tensas relações observadas ao longo dos últimos governos; (3) um esforço de descaracterização do Brasil como país terceiro-mundista ${ }^{42}$.

Por trás destes pontos, encontrava-se a noção, amplamente difundida por Collor durante sua campanha e após sua eleição, de que o Brasil deveria ser submetido a um profundo movimento de modernização. Se modernização, na acepção do novo governo, era entendida como a abertura do país às forças de mercado, em consonância com o receituário neoliberal difundido pelo governo Bush, seria necessário adaptar políticas domésticas e externa de forma concomitante. Azambuja, por exemplo, atesta que o primeiro traço distintivo

\footnotetext{
${ }^{40}$ Esta seção foi adaptada de Casarões, 2011.

${ }^{41}$ Hirst, Monica e Pinheiro, Letícia. "A Política Externa do Brasil em dois tempos". Revista Brasileira de Política Internacional, vol. 38, no. 1, 1995; Cervo, Amado Luiz. "Política de Comércio Exterior e Desenvolvimento: a experiência brasileira”. Revista Brasileira de Política Internacional, vol. 40, no. 2, 1997.

${ }^{42}$ Hirst e Pinheiro, 1995, p. 6.
} 
da política externa de Collor foi a tentativa de ampliação da competitividade internacional do Brasil, garantindo melhores condições de acesso a mercados, créditos e tecnologia ${ }^{43}$. Na mesma linha, Pereira argumenta que a adoção de um modelo de desenvolvimento orientado para o mercado buscou, a um só tempo, empreender uma inserção internacional mais "competitiva" do país, eliminar áreas de atrito com os países desenvolvidos, além de estreitar relações "com atores internacionais que passaram a ganhar espaço significativo nos negócios internacionais, a exemplo dos diferentes organismos internacionais" ${ }^{\prime 4}$.

Esses movimentos dos quais se ocupava a nova política externa não rompiam, contudo, com as diretrizes básicas que haviam guiado a diplomacia brasileira ao longo das últimas três décadas. $\mathrm{Na}$ avaliação de Cruz Jr., Cavalcante e Pedone, o governo Collor reafirmaria, tanto em atos como em palavras, compromissos tradicionais do país com respeito à soberania nacional, desenvolvimento econômico, cooperação internacional, multilateralismo e devoção da paz $^{45}$. Para os autores, a mudança da política externa durante o período ocorreu mais no plano da forma do que da essência: diante do esgotamento do modelo de substituição de importações, o governo viu-se obrigado a revisar sua política externa comercial, o tratamento do capital estrangeiro e o papel do Estado na economia sob uma ótica liberalpragmática, sem no entanto descurar das aspirações mais gerais da política externa brasileira $^{46}$.

Além disso, duas macro-transformações informaram a mudança no projeto de inserção internacional do Brasil. Em primeiro lugar, o fim da Guerra Fria acabou por destituir das relações internacionais seu forte componente ideológico, e desorientou, em alguma medida, as possibilidades de alinhamento dos países semi-periféricos, ou "potências médias" 47 . Por isso mesmo, a despeito da tentativa brasileira em resgatar o alinhamento com os Estados Unidos, ainda se notavam posturas afinadas com o discurso terceiro-mundista característico do Pragmatismo Responsável ${ }^{48}$. Em segundo lugar, a consolidação do processo de redemocratização do país abriu diversos canais de participação da sociedade civil e de grupos

\footnotetext{
${ }^{43}$ Azambuja, Marcos Castrioto de. "A Política Externa do Governo Collor”. São Paulo: Instituto de Estudos Avançados, 1991.

44 Pereira, 2005, p. 305.

${ }^{45}$ Cruz, Cavalcante e Pedone, 1993 p. 119.

${ }^{46}$ Ibid., p. 120

${ }^{47}$ Idem.

48 "Por exemplo, as visitas presidenciais e ministeriais ao Japão, Estados Unidos e Europa, que ocorreram entre o fim de 1990 e em 1991, claramente assinalaram o abandono de uma retórica terceiro-mundista e de confrontação. Não obstante, durante a reunião de cúpula de Guadalajara (julho de 1991) e a viagem presidencial ao sul da África (em setembro do mesmo ano), Collor atacou veementemente os países industrializados por sua intransigência e falta de sensibilidade com relação ao mundo não-industrializado, particularmente em relação à dívida externa e marginalização de seus produtos no mercado mundial”. Cruz Jr., Cavalcante e Pedone, 1993, p. 122.
} 
de interesse organizados nas definições da política externa, principalmente por meio da opinião pública. É natural, portanto, que a chancelaria brasileira tivesse que lidar com novas demandas que se encontravam latentes no seio da sociedade ${ }^{49}$. Por fim, concluem os autores que o governo Collor

\begin{abstract}
“caracterizou-se pela adoção de várias 'políticas externas', em vez da aplicação de um padrão de comportamento uniforme, direto ou consensual. Na medida em que o modelo bipolar das relações internacionais, tão simplista quanto maniqueísta, desaparecera, junto às políticas que ele pressupunha, o Brasil adentrou um período de espera, que talvez ainda perdure, no qual a política externa buscou acomodar-se, ou adaptar-se, aos novos tempos",50
\end{abstract}

Uma leitura mais crítica sobre o mesmo processo, realizada por Cervo e Bueno, assume que o pensamento brasileiro de política exterior guiou-se pelo abandono, ou pela “demolição instantânea”, do Estado desenvolvimentista, que reforçava a autonomia da política externa com feições nacionalistas, e a incorporação do Estado normal, invenção latinoamericana do início dos anos 1990 que visava ao estabelecimento incondicional dos ditames de Washington nos planos econômico e externo ${ }^{51}$. Para além das pressões externas, contudo, a emergência do paradigma do Estado normal, responsável pela relativa inconsistência e heterogeneidade da política externa brasileira do período Collor ${ }^{52}$, relaciona-se com a chegada ao poder, ao redor da América Latina, de grupos sobreviventes ao esmagador consenso cepalino que vigorava desde os anos 1950 no continente. Ademais, "[i]rrompeu com tamanha força, coerência e convergência regional entre os países, que nada se lhe compara em outras partes do mundo" $" 53$.

Três são as faces do Estado normal, observadas ao longo da década de 1990 em grande parte dos países latino-americanos: a do Estado subserviente, cuja principal característica seria a submissão às coerções do centro hegemônico do capitalismo; a do Estado destrutivo, que coloca fim ao núcleo duro da economia nacional e transfere renda ao exterior; por fim, a do Estado regressivo, que reserva para a nação as funções da infância social $^{54}$. Essas características justificariam, de alguma forma, a visível guinada ao americanismo por parte das elites neoliberais latino-americanas, em busca da renovação de uma aliança especial, esquecida, por exemplo, durante o governo Reagan. O exemplo mais

\footnotetext{
${ }^{49}$ Idem, pp. 121-2.

${ }^{50}$ Idem, p. 121.

${ }^{51}$ Cervo e Bueno, 2002; Cervo 1997.

${ }^{52}$ Cf. Batista, 1993; Hirst e Pinheiro, 1995.

${ }^{53}$ Cervo, 2003, p. 15.

${ }^{54}$ Cervo e Bueno, 2002, p. 457.
} 
sintomático, neste sentido, seria o alinhamento da Argentina aos Estados Unidos no fim dos anos 1980 e o estabelecimento de "relações carnais", segundo o então chanceler daquele país, Guido di Tella, que se estenderam ao longo da próxima década.

À semelhança da adoção incondicional do paradigma americanista por parte de nossos vizinhos, o Brasil também se rendera, na opinião de Cervo e Bueno, às relações especiais com os Estados Unidos, motivado pela "normalização" do Estado 55 . Mais do que isso, na opinião de Moniz Bandeira, a adesão ao receituário do Consenso de Washington e o alinhamento ideológico e político aos Estados Unidos representaram, no período, condição fundamental para que os países latino-americanos pudessem renegociar a dívida e receber recursos das agências financeiras internacionais. Ao mesmo tempo, prossegue o autor,

\footnotetext{
“a liberalização do comércio exterior, promovida unilateralmente pelos países latino-americanos, permitiria que os Estados Unidos, sem mais privilegiar os interesses do setor bancário na questão da dívida externa, atendessem à pressão dos exportadores norte-americanos e transformassem em superávit seu déficit comercial com a região",56.
}

Se é correto falar de um pêndulo paradigmático que guia a inserção internacional do Brasil republicano ${ }^{57}$, cujos extremos são o americanismo, no qual as relações beiram a subserviência à potência hemisférica, e o globalismo, que se traduziria na busca pela autonomia externa por meio da diversificação de parceiros internacionais, a política externa brasileira vivenciou, com a eleição de Collor, uma mudança brusca de extremidades, da segunda para a primeira. Na opinião de Maria Regina Soares de Lima, tal transformação estaria relacionada com uma estratégia chamada "modernização via internacionalização",58, nos termos cunhados por Przeworski, que implica a adoção de padrões políticos, econômicos e culturais do mundo capitalista avançado, mas que aceita, em contrapartida, uma submissão parcial da soberania nacional nessas áreas ${ }^{59}$.

É importante ressaltar que a estratégia de aproximação do Primeiro Mundo, mais especificamente de reconstruir a aliança especial com os Estados Unidos, passou ao largo dos interesses tradicionais do Itamaraty ${ }^{60}$. Esse movimento teve duas causas principais, elencadas

\footnotetext{
${ }^{55}$ Cervo e Bueno, 2002.

${ }^{56}$ Moniz Bandeira, Luiz Alberto. Relações Brasil-EUA no Contexto da Globalização. São Paulo: Ed. SENAC, 1999, p. 159.

${ }^{57}$ Como sugere, por exemplo, Pinheiro (2000).

${ }^{58}$ Lima, Maria Regina Soares de. "Ejes Analíticos y Conflicto de Paradigmas en la Política Exterior Brasileña". America Latina/Internacional, vol. 1, no. 2, 1994.

59 (Lima, 1994, pp. 40-1)

60 (Lima, 1994; Batista, 1993)
} 
por Leticia Pinheiro ${ }^{61}$. A mais notável delas seria, seguindo o argumento de Lima, uma dissociação entre os valores e razões pragmáticas do Executivo, alinhados aos interesses norte-americanos, e aqueles das forças políticas e sociais mais relevantes, que se opunham a essa alternativa $^{62}$. Além disso, as rápidas transformações internacionais observadas com o fim da Guerra Fria obsolesciam, no mesmo passo, o discurso terceiro-mundista que representava uma das principais marcas do globalismo ${ }^{63}$.

Essa busca por modernização via alinhamento aos EUA seria não somente destrutiva, como notaram Cervo e Bueno, mas também excessivamente ingênua. Desde a campanha presidencial até assumir a presidência, Collor adotou um discurso de levar o Brasil rumo ao Primeiro Mundo que parecia desconhecer, nas palavras de Miyamoto, os mecanismos de poder que constituem a realidade internacional. Segundo o autor, o presidente cometia, na direção que conferia à política externa brasileira, um duplo pecado: em primeiro lugar, acreditava que as vontades individuais poderiam sobrepor-se às premissas que orientam o sistema internacional, confiando numa ruptura da ordem vigente a partir da periferia, sem qualquer resistência dos centros de poder. Ademais, "apresentava-se igualmente despreparado para elaborar projetos amplos como a inserção do País no sistema global de poder, ignorando os próprios indicadores nacionais e as dificuldades existentes para melhorá-los"64.

Tais questões detectadas na literatura seriam responsáveis, no plano das ações, por posicionamentos contraditórios, incapazes de garantir ao Brasil os benefícios de uma relação mais próxima com o grande pólo de poder pós-Guerra Fria, por um lado, tampouco as vantagens da busca pela autonomia pelo não-alinhamento, por outro. Além disso, como afirmam Hirst e Pinheiro ${ }^{65}$, a crise política deflagrada no primeiro ano do governo, em função da deterioração dos indicadores macroeconômicos (inflação e dívida externa, em particular) e da incapacidade de Collor em construir uma coalizão legislativa estável, impediu a concretização de uma agenda econômica inicialmente ampla. Do pacote de reformas previsto no início do mandato, somente as novas determinações no campo do comércio exterior foram mantidas, no que tange à inserção internacional do Brasil. As autoras prosseguem afirmando que, frente às reviravoltas internas, "foi impossível evitar a deterioração da imagem do Brasil na comunidade internacional”, em particular junto às nações industrializadas e aos grupos

\footnotetext{
${ }^{61}$ Pinheiro 2000

${ }^{62}$ Lima 1994 p. 42

63 (Fonseca Júnior, 1998; Pinheiro, 2000, p. 311)

64 (Miyamoto, 1991, pp. 9-10)

${ }^{65}$ Hirst e Pinheiro 1995
} 
financeiros, seja em função da atitude errática do governo brasileiro frente à Guerra do Golfo ou a forma "pouco dócil" com que lidou, no princípio, com as negociações da dívida ${ }^{66}$.

As características mais gerais apontadas pela literatura sobre a política externa do governo Collor fizeram com que esta se tratasse, fundamentalmente, de um "projeto de voo curto" ${ }^{67}$. O agravamento da crise política, que transpôs as fronteiras das relações entre Executivo e Legislativo e corroeu a legitimidade do próprio governo interna e externamente, minou qualquer possibilidade de inserção internacional baseada no neoliberalismo. Com a suspensão do presidente da República em função da abertura do processo de impeachment, em setembro de 1992, vê-se recrudescer, no seio da sociedade, posturas neodesenvolvimentistas e a politização da agenda externa em torno de temas como meioambiente e direitos humanos. Ademais, ampliou-se a capacidade parlamentar de influir sobre a política externa, bem como diversificou-se o número de atores atentos às questões exteriores do Brasil, em função da crescente mobilização de setores da sociedade civil em torno de organizações não-governamentais ${ }^{68}$. A soma destes fatores garantiria ao governo Itamar uma inserção internacional centrada no multilateralismo, na posição de "sócio privilegiado" na integração continental e na condição de global trader ${ }^{69}$, construindo um paradigma que seria levado adiante pelo próximo governo.

O conjunto de teses apresentado nesta seção pode ser entendido como uma espécie de consenso sobre o que representou a política externa do governo Collor. Resumidamente, pode-se dizer que se tratou de uma política de ruptura com o corolário nacionaldesenvolvimentista adotado por duas décadas, em que o presidente chamou para si o protagonismo na definição da agenda internacional de maneira sem paralelos na história da política externa republicana. Marginalizou-se, por um lado, o tradicional papel do Itamaraty e ignorou-se de forma sistemática, por outro, os interesses dos setores econômicos dominantes, contrários às medidas de abertura comercial e aumento (quase predatório) da competitividade externa da indústria. Imprimiu-se uma guinada tão brusca em termos paradigmáticos à política externa brasileira que a correção de rumos era simplesmente uma questão de tempo, reafirmando a ideia do "voo curto".

\subsection{Uma interpretação alternativa: a autonomia pela modernização}

\footnotetext{
${ }^{66}$ Hirst e Pinheiro, 1995, p. 7.

${ }^{67}$ Idem.

${ }^{68}$ Idem, p. 8.

${ }^{69}$ Idem, p. 11.
} 
Com base na exposição das interpretações sobre as transformações empreendidas pelo governo Collor no campo da política externa, é possível agruparmos as visões descritas em três grandes grupos, pensados em termos da sua posição paradigmática, sua formulação e sua implementação. De acordo com uma linha interpretativa, a forma como Collor buscou a inserção internacional do Brasil foi incoerente, ao apresentar posições tanto de alinhamento com os Estados Unidos quanto de conservação da retórica terceiro-mundista, muito embora essa incoerência tenha sido fruto não necessariamente de uma vontade pessoal do presidente, mas de constrangimentos impostos pela mudança da estrutura internacional.

Uma segunda interpretação atribui a Collor protagonismo na redefinição da orientação internacional do país. O presidente, de maneira deliberada, teria alijado o Itamaraty do processo decisório da política externa brasileira, imprimindo um voluntarismo bastante característico em direção à subserviência aos centros capitalistas de poder e inaugurando um período no país caracterizado pelo Estado normal. A guinada paradigmática teria sido completa, de uma tradição globalista, que perdurou até o governo Sarney, a uma postura de alinhamento automático com os Estados Unidos, não havendo, ao contrário do que sugere a primeira interpretação, qualquer tipo de incoerência. Aliás, a coerência, neste caso, teria sido produzida justamente pela retirada do componente burocrático como vetor de resistência às mudanças desejadas - e empreendidas - pelo presidente Collor enquanto esteve no poder.

Uma terceira interpretação, por fim, sugere que a estratégia de modernização adotada pelo governo Collor tinha sua razão de ser, em face às transformações estruturais pelas quais passavam as economias latino-americanas, sendo que seu rumo natural seria, de fato, o neoliberalismo. Contudo, a adesão unilateral ao Consenso de Washington enfraqueceria a posição dos países semiperiféricos, uma vez que se observou um movimento predatório contra as bases industriais, os recursos básicos de poder e, no limite, contra a própria soberania nacional.

\section{Quadro 1 - Interpretações sobre a política externa do governo Collor}

\begin{tabular}{|l|l|l|l|}
\hline & Orientação internacional & \multicolumn{1}{|c|}{ Agente da mudança } & \multicolumn{1}{c|}{ Resultados } \\
\hline "Ambiguidade estrutural" & $\begin{array}{l}\text { Posições ambíguas entre } \\
\text { o americanismo e o } \\
\text { globalismo }\end{array}$ & $\begin{array}{l}\text { Transformações na } \\
\text { estrutura do SI }\end{array}$ & $\begin{array}{l}\text { Incoerência na conduta } \\
\text { externa }\end{array}$ \\
\hline "Voluntarismo predatório" & $\begin{array}{l}\text { Americanismo } \\
\text { ideológico; Estado } \\
\text { normal }\end{array}$ & $\begin{array}{l}\text { Presidente Collor de } \\
\text { Mello }\end{array}$ & $\begin{array}{l}\text { Política externa coerente, } \\
\text { mas predatória e } \\
\text { subserviente }\end{array}$ \\
\hline "Adesão unilateral" & Neoliberalismo & $\begin{array}{l}\text { Fragilidades econômicas } \\
\text { da semiperiferia }\end{array}$ & $\begin{array}{l}\text { Corrosão dos elementos } \\
\text { de poder nacional }\end{array}$ \\
\hline
\end{tabular}

Fonte: elaboração própria. 
Uma releitura da transição da política externa observada com a ascensão de Fernando Collor de Mello ao poder, à luz do modelo analítico proposto, permite-nos delinear uma interpretação alternativa. Em primeiro lugar, contestamos a noção básica de que a inserção internacional do Brasil foi incoerente, oscilando entre posições terceiro-mundistas e próEstados Unidos. Incoerência, nesse sentido, implicaria a desconsideração do pressuposto analítico básico da racionalidade, transferindo a causalidade para o ator individual, motivado ideologicamente. Havia, é fato, a permanência de uma dicotomia entre autonomia e subordinação em algumas áreas, de acordo com o poder relativo do Brasil em cada uma delas. Isso não quer dizer, contudo, que o país assumisse posições distintas a respeito dos mesmos temas, tampouco sugere que se tenha abandonado, como preferência básica, a maximização dos ganhos internacionais.

Por isso mesmo, é necessário abrirmos um parêntese sobre uma distinção realizada anteriormente, entre preferências e estratégias. Quais seriam, em termos gerais, as preferências do Brasil como ator internacional? Fala-se muito em busca pela autonomia ${ }^{70}$ como um elemento central dos movimentos recentes da política externa brasileira. Destarte, a busca pela autonomia, mesmo que em alguns momentos tenha sido coibida (em particular por pressões estruturais), nunca deixou de constar no topo das preferências do Brasil no contexto de sua inserção internacional. Isso é verdade pelo menos desde fins da década de 1950, quando o país começa a lançar as raízes daquilo que, pensado num conjunto coerente, seria chamado de política externa independente nos governos Jânio Quadros e João Goulart ${ }^{71}$. Em termos mais gerais, pode-se afirmar que, desde que o Brasil atingiu o estatuto de potência recém-industralizada (ou semiperiférica), sua sobrevivência - que, segundo a tradição waltziana, é o objetivo de qualquer Estado na política internacional ${ }^{72}$ - deixou de estar atrelada à noção de alinhamento automático, ou bandwagoning. Daí em diante, pôde-se falar em autonomia como sinônimo de interesse nacional, embora essa postura autônoma tenha assumido várias facetas ao longo do tempo ${ }^{73}$.

Nesse sentido, a dualidade autonomia/subordinação, fio condutor do argumento de Lima e reproduzido por nosso modelo, adquire novo significado. Subordinação, nos moldes das abordagens subimperialistas, assume um caráter estático no tempo na medida em que não

\footnotetext{
${ }^{70}$ Este ponto é extensivamente tratado em Vigevani e Cepaluni, 2010.

${ }^{71}$ Muito embora Moura já utilizasse o termo para se referir à política externa do Estado Novo, quando o Brasil adotou um padrão muito singular de conduta externa, a chamada "diplomacia pendular" entre os Estados Unidos e a Alemanha nazista, como forma de garantir a autonomia internacional mesmo em condições adversas, ao promover a eqüidistância. Moura, Gerson. Autonomia na Dependência. Rio de Janeiro: Nova Fronteira, 1980. 72 Waltz, 1979.

${ }^{73}$ Fonseca Júnior, 1998.
} 
é possível superá-la, em função da estrutura e das dinâmicas do capitalismo. Quer dizer, sob a lente marxista, os países semiperiféricos aceitam sua condição de dependência diante da constatação de que não há como mudar a ordem vigente em seu favor para além do ponto em que já se encontram, a semiperiferia. Enfatiza-se aqui, por outro lado, que a noção de subordinação deve ser encarada, do ponto de vista da potência média, como um resultado subótimo de um jogo estratégico no qual ela é a parte mais fraca. Ou seja, tal condição seria transitória, posto que o acúmulo de recursos materiais de poder pode reverter o resultado do jogo em seu favor (em situações em que, naturalmente, não se trate de uma rodada só), e indesejável, visto que o valor atribuído a ela é inferior ao de outras opções, que não foram contempladas no equilíbrio.

O desejo pela autonomia, entretanto, não significa que ela assumirá o mesmo formato em todos os momentos. Isto é, as estratégias referentes à busca pela autonomia variam ao longo do tempo, condicionadas por um cálculo de custo-benefício que contempla variáveis no plano sistêmico e doméstico. Na literatura sobre política externa do Brasil já se identificaram distintas qualificações ao termo: autonomia na dependência ${ }^{74}$, a respeito da diplomacia pendular da política externa do Estado Novo; autonomia pelo distanciamento (Fonseca Júnior, 1998), na caracterização do pragmatismo responsável de Geisel à diplomacia da Nova República; autonomia pela participação ${ }^{75}$, ao descrever a política externa da década de 1990 , ansiosa por amplificar seu perfil internacional por meio da participação nos foros multilaterais; autonomia pela integração ${ }^{76}$, uma releitura do papel da integração regional como pilar da busca pela independência externa durante o governo Fernando Henrique Cardoso; autonomia pela diversificação ${ }^{77}$, definindo a estratégia da política externa do governo Lula. Em cada um dos casos, ainda que a autonomia seja a preferência, as variações nos termos representam as distintas estratégias às quais o Brasil recorreu ao longo do tempo, para aproximar-se de seu ganho máximo.

É neste contexto que propomos a ideia de autonomia pela modernização. Toma-se como pressuposto a ideia de que a busca pela autonomia tornou-se corolário da política externa brasileira nos últimos cinqüenta anos, não tendo sido abandonada em nenhum dos governos ou regimes que sucederam no país. Ou seja, descarta-se de antemão a possibilidade de que Collor, em seus arroubos voluntaristas, tenha sido capaz de mudar as preferências atreladas à política externa brasileira. Estamos tratando, afinal, o Estado como ator provido de

\footnotetext{
${ }^{74}$ Moura, 1980.

${ }^{75}$ Fonseca Júnior, 1998; Vigevani et al., 2003.

${ }^{76}$ Lampreia, 1999.

${ }^{77}$ Vigevani e Cepaluni, 2007.
} 
racionalidade. Rejeita-se também a ideia de que a modernização tenha sido produto ideológico do novo presidente, seja em função de preferências individuais, seja para meramente adequar-se ao discurso corrente no início da década de 1990. Ao contrário, a modernização foi uma estratégia adotada pelo governo Collor, diante de transformações estruturais e reacomodações domésticas, de continuar maximizando os benefícios do país, em direção à autonomia.

A “autonomia pela modernização" possui algumas características que a singularizam, se comparada com outras estratégias elencadas pela literatura. Em primeiro lugar, procura adequar o Brasil a uma profunda transformação estrutural, que impactou sobre a dimensão militar (com o fim da bipolaridade), econômica (com a emergência do neoliberalismo, em particular na periferia) e política (com a aparente universalização dos princípios democráticos). Segundo, utiliza as componentes da participação e integração como acessórias ao processo de modernização, na esteira do surgimento de novos temas internacionais e da formação de blocos econômicos como forma de se integrar à nova realidade da economia internacional. Por fim, mas não menos importante, a ideia de modernização encerra em si um processo de reacomodação societária, ou seja, acompanha um movimento em direção a um novo tipo de relação entre Estado e sociedade - tanto no campo político, com o aprofundamento do processo de transição democrática, quanto no econômico, com as pressões de diversos setores sociais em favor da liberalização comercial.

Diante deste pano de fundo podemos entender, por exemplo, a tentativa imediata de aparar as arestas das relações Brasil-Estados Unidos. Como se sabe, elas haviam atingido, durante a década de 1980, níveis de tensão bastante elevados, em função dos contenciosos bilaterais abertos acerca da reserva de mercado de informática, que o Brasil tratava como instrumento inabalável de desenvolvimento industrial, e a respeito também das patentes no âmbito da OMC. A questão da informática, inclusive, havia gerado o anúncio inédito, por parte do governo Reagan, de sanções comerciais contra o Brasil, no despertar do governo Sarney. A moratória da dívida externa, anunciada pelo ministro Dílson Funaro em fevereiro de 1987, contribuíra, adicionalmente, para a deterioração das relações bilaterais. Essas relações, por mais que ambos os governos ensaiassem um retorno à normalidade ainda em fins da década de 1980, somente seriam recompostas, em sua plenitude, com a chegada de Collor ao poder, em 1990.

A afirmação das relações com os Estados Unidos, contudo, não representaram nem um alinhamento automático àquela potência, tampouco o abandono da autonomia em favor da subserviência. A estratégia do distanciamento, que caracterizara a política externa brasileira 
de Geisel e Figueiredo e adentrara, embora de maneira relutante, a Nova República, perdeu fôlego ao longo da década de 1980. Trata-se de uma fórmula relativamente simples: o resgate da hegemonia americana, que havia se intensificado no decurso do governo Reagan, e a simultânea decomposição da União Soviética, cujo modelo econômico tornava-se progressivamente irrelevante, impuseram ao mundo uma espécie de crise da ordem internacional. Crise, que fique claro, no sentido de que se abalaram as fundações da estrutura global do pós-Segunda Guerra, de uma forma muito mais brusca e profunda do que haviam sido os "movimentos tectônicos" das duas décadas anteriores, que ainda assim impeliram vários analistas a falar em nova multipolaridade, declínio da supremacia estadunidense, etc. Agora, pelo contrário, a crise se dava em direção à instauração de um momento unipolar, em que os Estados Unidos se afirmavam como o único pólo de poder com contornos definidos.

Como segundo elemento desta fórmula, tem-se a crise do Terceiro Mundo. Este é, a bem dizer, um subcapítulo das transformações estruturais em marcha. Afinal, a derrocada do terceiro-mundismo, seja como bloco alternativo de poder ou mero "estado de espírito", já vinha sendo desenhada desde fins da década de 1970, diante da vulnerabilidade estrutural dos países periféricos (e semiperiféricos) aos choques do petróleo. O desgaste intensificou-se com a crise da dívida, produto direto do resgate da hegemonia norte-americana pelo governo Reagan, que representou, possivelmente, o mais duro golpe desferido sobre a unidade das nações em desenvolvimento. Ao final da década, a dívida externa, que em alguns casos converteu-se também em surtos hiperinflacionários, havia corroído as economias nacionais e reduzido, de maneira brusca, o intercâmbio comercial na periferia. No caso do Brasil, as relações com a África, entre 1985 e 1990, viram cair pela metade as exportações para o continente, e reduzir para menos de um terço as importações ${ }^{78}$. Com a América Latina, donde se destaca a relação com a Argentina, o processo foi menos intenso, em função da proximidade geográfica, mas também foi marcado pelo declínio, a despeito da retórica de integração observada na esteira da transição democrática de ambos os lados do Prata $^{79}$ (Plá, 1992).

Um elemento adicional a se considerar é a crise do modelo do Estado desenvolvimentista pela qual passava o Brasil. Os revezes econômicos que o país enfrentou, desde a primeira crise do petróleo, foram minando aos poucos o consenso nacionaldesenvolvimentista que se formara desde a década de 1930. No contexto de uma crise

\footnotetext{
${ }^{78}$ Ribeiro, Cláudio Oliveira. "Adjustment Changes: a política africana do Brasil no pós-Guerra Fria”. Revista de Sociologia e Política, vol. 18, no. 35, 2010, pp. 55-79.

${ }^{79}$ Plá,
} 
internacional aguda como a da década de 1980, multidimensional no sentido de ter impactado, como já se disse, sobre as relações políticas, militares e econômicas, observa-se a aceleração da corrosão do desenvolvimentismo, primeiro em suas bases societárias - as elites econômicas foram progressivamente abraçando a retórica neoliberal como forma de solucionar a crise brasileira - e, algum tempo depois (quando já se nota reflexo no debate constituinte, entre 1987 e 1988), na esfera propriamente política. Ao cabo do processo, já se tinham lançado as bases para a abertura econômica ${ }^{80}$, sob o signo do neoliberalismo e os parâmetros do Consenso de Washington, que no caso brasileiro não havia acompanhado a abertura democrática dos anos anteriores.

É possível asseverar que houve, nos termos do modelo proposto, uma mudança nos payoffs atribuídos a cada uma das estratégias. O distanciamento como forma de alcançar a autonomia perdera seu valor fundamental, na medida em que os sustentáculos da política externa brasileira desde o pragmatismo responsável - haviam também perdido a capacidade de intercâmbio e peso político em função das múltiplas crises. Nesse sentido, a aproximação dos centros de poder econômico, em particular dos Estados Unidos, serviria a três propósitos simultâneos: (1) criaria novas vias de inserção internacional para o Brasil, num cenário de pós-Guerra Fria; (2) amenizaria, ao menos parcialmente, possivelmente a principal vulnerabilidade estrutural da economia brasileira, a dívida externa; (3) atenderia, por meio da adesão (seletiva, em nossa opinião) dos princípios delineados pelo Consenso de Washington, a uma demanda societária em favor da abertura econômica e da construção de um novo modelo de Estado.

Com relação ao primeiro propósito, cumpre destacarmos as transformações qualitativas que se impunham ao final da Guerra Fria. Relativizou-se a centralidade do poder militar diante do primado da liberalização econômica e dos movimentos de globalização, num cenário de crescente interdependência. Novos temas, como a democracia, os direitos humanos, o meio-ambiente e a não-proliferação nuclear, assumem o coração da agenda internacional. Sem nos estendermos individualmente em cada um destes assuntos, vale dizer que, em geral, o Brasil buscou adaptar-se a essa nova realidade dispondo dos recursos que possuía.

À luz desta percepção, devemos entender, por exemplo, as mudanças empreendidas no campo da informática. Desde fins da década de 1970, a questão das tecnologias sensíveis colocava-se como um dos temas de maior zelo por parte do regime militar. A reserva de

\footnotetext{
${ }^{80}$ Cuja inflexão mais importante talvez tenha sido a Nova Política Industrial de Sarney, datada de 1987.
} 
mercado para o incipiente campo da informática, acreditavam tanto governo como setores societários envolvidos (sobretudo militares e empresários), seria uma espécie de salvaguarda à soberania nacional em áreas de importância estratégica. Por isso mesmo, observa-se a ação unilateral por parte do Brasil, ainda no governo Geisel, contrariando os interesses das empresas transnacionais de informática, grande parte das quais sediadas nos Estados Unidos. Na passagem do governo Carter para Reagan, em 1981, as escolhas brasileiras no campo da informática, muito embora comprometessem setores econômicos norte-americanos, não afetavam as relações bilaterais de tal maneira a justificar medidas coercitivas. Esforços consistentes não eram nem mesmo feitos no sentido da negociação.

O quadro começa a mudar em 1984, quando o governo brasileiro aprova a Lei da Informática, endurecendo os termos da reserva de mercado. Além disso, o resgate da hegemonia norte-americana por parte da administração Reagan, à mesma época, impôs um aumento das pressões sobre práticas infensas ao livre-comércio por parte de seus parceiros comerciais. Em discurso com forte simbolismo, aos 7 de setembro de 1985, o presidente dos Estados Unidos declarava abertura de processos contra Brasil, Coreia do Sul, Japão e Comunidade Europeia, alegando práticas comerciais injustas, com base na legislação comercial norte-americana. Nota-se que as relações entre o Brasil e os EUA invertem de sentido, com ameaças recorrentes de coerção por parte do governo Reagan, que foram assumindo forma ao longo dos anos de 1985 e 1986.

Num primeiro momento, as ameaças norte-americanas eram de baixa credibilidade. Como já sugerimos, na esteira da análise de Odell, os termos com que o governo Reagan tratou a questão da informática brasileira eram ao mesmo tempo vagos, pois não havia se determinado que tipo de sanções seriam aplicadas contra o Brasil, e relutantes, já que nem o Congresso norte-americano, nem mesmo parcelas significativas do setor de informática daquele país subscreviam à atitude do presidente em levar o caso brasileiro ao United States Trade Representative. Isso facilitou a resistência brasileira, que não se moveu de maneira significativa diante das pressões do vizinho mais forte, muito embora algumas cisões internas - até mesmo entre ministros ${ }^{81}$ - já se firmassem a respeito da continuidade da reserva de mercado.

O valor atribuído pelo Brasil à reserva de mercado, no contexto de sua inserção internacional, modificou-se ao longo do tempo. Não se trata, contudo, de uma mudança

\footnotetext{
${ }^{81}$ Destaca-se, por exemplo, a disputa entre Abreu Sodré, então chanceler, opositor da reserva de mercado e defensor de uma abordagem de competitividade para a indústria nacional, e os ministros militares, ao longo do ano de 1986 Cf. Tapia, 1995.
} 
brusca, mas sim de um processo que culmina com o fim oficial da Lei da Informática, em 1991. Do ponto de vista doméstico, diversos segmentos econômicos, outrora apoiadores da reserva de mercado como um instrumento de proteção industrial, foram progressivamente alterando seu discurso, que assumia contornos liberais. Em termos políticos, a retórica desenvolvimentista foi dando lugar a declarações contrárias a práticas protecionistas e à própria reserva de mercado, donde se destacam as opiniões do próprio presidente Sarney, em meados de 1987.

Não obstante, as transformações domésticas não seriam capazes, per se, de alterar de maneira derradeira a dinâmica do jogo estratégico envolvendo a questão da informática. Dois movimentos no plano sistêmico devem ser igualmente destacados. O primeiro deles diz respeito à credibilidade da ameaça norte-americana, que aumenta na medida em que a agenda se torna mais específica (concentrando-se, no caso, nas questões de software) e as sanções se tornam mais bem direcionadas (e o Brasil passa a dimensionar, com mais clareza, os custos e os benefícios da resistência). Além disso, e de igual relevo, a relativa obsolescência do poder militar vis à vis a capacidade econômica dos Estados faz com que a importância atribuída à proteção do mercado de informática como setor militarmente estratégico, como forma de garantir a autonomia nacional, seja também minimizada ao longo do tempo. Claro que a sensível perda de importância do estrato militar no contexto da Nova República, intencionalmente sublinhada pelo novo presidente, é um fator agravante neste contexto. Em todo caso, nota-se que, diante desse conjunto de transformações, a estratégia brasileira de resistir às pressões norte-americanas perdeu sustentação, não porque o Brasil passa à posição de subordinação aos Estados Unidos, mas porque os payoffs de cada uma das estratégias transformam-se, de maneira profunda, neste período.

A mudança de comportamento a respeito da informática nos ajuda a entender outro tópico central da agenda internacional brasileira ao final da década de 1980: a dívida externa. Num contexto de issue-linkage, isto é, em que os temas da pauta bilateral se entrecruzam (cf. Kahler, 1985), o Brasil passa a usar a questão da informática em particular, no contexto da liberalização econômica em geral, para favorecer sua própria posição no tocante à negociação da dívida. De fato, desde a deflagração da crise da dívida, em meados de 1982, que interrompera as concessões de empréstimos voluntários ao Brasil, o país somente recebia recursos condicionados ao processo de renegociação da dívida. O cenário mudaria em 1990, quando o país contou com desembolso de empréstimos volumosos, na casa dos US\$900 milhões. Como forma de aumentar a captação de recursos externos, o governo Collor estimulou a entrada de capitais, relaxando os mecanismos de entrada e saída de investimentos 
por meio de uma expressiva desregulamentação e liberalização financeira, sobretudo após a troca de comando da política econômica, em maio de 1991.

Assim, diante de uma situação de vulnerabilidade estrutural provocada pela dívida, a promoção de medidas liberais atendia ao duplo propósito de renovar a capacidade econômica do país (mesmo que se possa condenar sua eficácia no médio prazo) e, ao mesmo tempo, permitir que o Brasil criasse condições mais favoráveis para a negociação da dívida, nos termos sugeridos pelos Estados Unidos no chamado Plano Brady ${ }^{82}$. Neste caso, bem como na questão da informática, a adesão aos princípios liberais não parece ter representado qualquer ensaio de subordinação ou alinhamento automático (que seriam, portanto, escolhas subótimas), mas sim um reflexo de transformações da própria matriz de ganhos da política externa brasileira, na qual a estratégia do protecionismo e do distanciamento dos Estados Unidos tornam-se, em termos do payoff atribuído, menos atrativas que a estratégia da abertura econômica.

O aprofundamento do Mercosul, por fim, representa uma estratégia multilateral destinada, a um só tempo, a promover a liberalização dos mercados do Cone Sul (modernização) e fortalecer a capacidade econômica de seus membros (integração). Neste movimento encontram-se, portanto, as duas vertentes da estratégia brasileira na busca pela autonomia em sua inserção internacional. A América Latina, a esse respeito, já se configurava como espaço preferencial de relações econômicas e políticas desde o governo Figueiredo (especialmente após a resolução do controvérsia Itaipu-Corpus, em 1979) e, mais intensamente, na esteira dos processos de democratização. As relações com a Argentina, nesse sentido, assumem enorme importância para a política externa brasileira. No início, a (re)construção das relações regionais foi impulsionada pela deterioração das relações com os Estados Unidos, em meados da década de 1980. Além disso, cumpre assinalarmos a emergência da integração regional como uma opção estratégica dos países em desenvolvimento, à semelhança da experiência européia (e, em menor grau, asiática). Analúcia Pereira resume o processo da seguinte forma:

“A percepção de que a América Latina, principalmente o sul do continente,
constituía um 'espaço vazio' [nas palavras do próprio presidente Sarney], em nível
mundial, onde ainda não havia sido iniciado um processo de criação de uma área
política e econômica, fez com que o Brasil procurasse romper o isolamento e

\footnotetext{
${ }^{82}$ Plano de reestruturação da dívida externa dos países latino-americanos, lançado pelo então Secretário do Tesouro, Nicholas Brady, em 1989. Implicava a renovação e renegociação da dívida externa e exigia, em contrapartida, a adoção, por parte dos países devedores, de reformas de mercado.
} 
aproveitasse o espaço geográfico na tentativa de maximizar as possibilidades de ação no sistema internacional" $" 83$

Politicamente, o Brasil buscou valer-se das novas vias de cooperação com os países da região, especialmente com o vizinho argentino, como forma de potencializar suas posições internacionais. "A coincidência de interesses levaram os dois países a orientarem-se por políticas que promovessem as condições necessárias para um posicionamento mais incisivo no plano internacional", anota Pereira ${ }^{84}$. Esta relação fez-se observar, com particular vigor, na questão da dívida externa, à qual o Brasil insistiu em conferir um caráter político, buscando unir vozes críticas ao receituário recessivo do Fundo Monetário Internacional e criando, com isso, uma espécie de "linha de solidariedade" com os países devedores ${ }^{85}$. A formação do Mecanismo Permanente de Consulta e Concertação Política (Grupo do Rio), em fins de 1986, buscou amplificar a capacidade de Brasil, Argentina, Colômbia, México, Panamá, Peru, Venezuela e Uruguai de questionar as políticas comerciais e macroeconômicas de Washington, e barganhar por seus interesses no âmbito da dívida externa de do GATT.

Do ponto de vista econômico, o Brasil atuou de forma a atenuar as discrepâncias comerciais com seus vizinhos. A primeira iniciativa do governo Sarney, nesse sentido, foi ordenar a importação de trigo e petróleo da Argentina, com vistas a aliviar o déficit comercial do país vizinho, firmando-se em seguida um acordo segundo o qual sempre que um dos parceiros apresentasse saldo negativo superior a US\$ 50 milhões, o outro prontamente aumentaria suas compras de forma a restabelecer o equilíbrio de intercâmbio (Bandeira, 1993 apud Pereira, 2003, p. 49). As relações aprofundar-se-iam a passos largos, dando azo a um processo real de integração, que inicialmente envolvia somente Brasil e Argentina, mas ao qual foram somados, em pouco tempo, Uruguai e Paraguai. Seixas Corrêa identifica quatro princípios basilares consagrados neste processo:

(1) a integração é fruto não somente da vontade política dos governos, estando também condicionada aos interesses dos agentes econômicos de cada uma das sociedades;

(2) a integração deve partir necessariamente de fluxos comerciais já existentes e com um certo grau de abrangência e complexidade;

\footnotetext{
${ }^{83}$ Pereira, 2003, p. 45.

${ }^{84}$ Idem, p. 49.

85 "Sabemos, contudo, que a solução definitiva [ao encaminhamento do problema da dívida] só virá quando, em resposta a nosso apelo conjunto, a economia internacional deixar de desfazer, através dos juros ou da deterioração do comércio, o que conseguimos com nosso ajustamento interno", sustentava Sarney, em discurso na fronteira entre o Brasil e a Argentina em novembro de 1985. Cf Sarney, 2008, p. 38.
} 
(3) a integração deve transcender a liberalização comercial, alcançando o setor produtivo, como forma de gerar escala, atrair investimentos e maximizar os recursos de produção, sobretudo em sua dimensão tecnológica;

(4) a integração de todo o continente partirá da escala sub-regional, mas irá além, superando até mesmo os esquemas previstos na $\mathrm{ALADI}^{86}$.

Prossegue o autor notando que o impacto do lançamento do processo de integração sobre a balança comercial de ambos os países não se fez esperar. Brasil e Argentina voltaram a ser parceiros de primeira importância recíproca, "com um volume de comércio que alcançou os dois bilhões de dólares nos dois sentidos e com uma crescente familiaridade dos consumidores de um mercado com os produtos oriundos do outro" ${ }^{\text {} 87}$.

Dessa forma, é possível anotar que o processo de integração do Cone Sul, que o governo Collor fez concretizar a partir da assinatura do Ata de Buenos Aires com a Argentina (1990) e do Tratado de Assunção, com Argentina, Paraguai e Uruguai (1991), tornou-se um elemento fundamental na estratégia de recomposição econômica dos atores regionais. Neste caso, observa-se o abandono da estratégia de hegêmona regional, já desgastada em função da rivalidade entre Brasil e Argentina em função da utilização energética da Bacia do Prata, e a adoção, por parte do governo brasileiro, de um comportamento de liderança. Com efeito, nos termos da autora, o Brasil buscou orientar a provisão do bem coletivo com vistas a benefícios que podem ser apropriados individualmente, sendo a consolidação do processo de integração regional fruto desse esforço.

Finalmente, é importante sublinharmos os fatores de inflexão nas relações do Brasil com o subcontinente. Novamente, a mudança de estratégia deve-se a um forte componente sistêmico: a fragilidade das economias latino-americanas é certamente um indutor à cooperação, sobretudo num momento de interdependência econômica em que a formação de blocos passa a ser uma alternativa viável para reduzir as vulnerabilidades estruturais dos países. Ademais, a perda de relevância do poder militar, como já notado, facilita a construção de confiança entre antigos rivais, como é o caso do Brasil e da Argentina, que desde meados da década de 1980 sinalizavam, por meio de acordos bilaterais, o abandono do projeto nuclear por ambas as partes. Não obstante, voltamos a um fator doméstico que operou como variável interveniente neste caso: a abertura política na região, e especialmente na relação com os argentinos. Pode-se dizer que a democratização reduziu os custos de transação, de um lado, e

\footnotetext{
${ }^{86}$ Seixas-Corrêa, 2006, p. 486.

${ }^{87}$ Idem, p. 487.
} 
aumentou o fluxo de informação, por outro. Percebe-se, com isso, a centralidade de uma dimensão doméstica na atribuição dos resultados das ações de política externa. 


\section{CAPÍtULO 2}

\section{A corrida presidencial de 1989 a partir das questões internacionais}

Embora, em geral, discuta-se a política externa de um determinado presidente/governo circunscrita ao período de seu mandato, muitas vezes as ideias, programas ou visões de mundo são moldadas a partir de eventos anteriores. Trata-se de algo particularmente visível no caso da política exterior de Fernando Collor de Mello, um político sem tradições partidárias ou convicções públicas anteriores que pudessem jogar luz sobre aquilo que viria a ser governo em questões internacionais. Por isso mesmo, deve-se atentar para a maneira como Collor utilizou a corrida presidencial de 1989, que se desenrolava contra um pano de fundo de grandes transformações mundiais, como uma espécie de "laboratório" no qual temáticas internacionais foram levantadas e que, no limite, inspiraram as propostas de política externa oficializadas em seu discurso de campanha, em junho daquele ano.

Neste capítulo, parte-se do entendimento de que as viagens internacionais realizadas pelos principais candidatos à presidência serviram-lhes de importante plataforma eleitoral, nas quais buscavam construir ou afirmar identidades políticas, articular alianças internacionais, ou simplesmente pegar carona na imagem de algumas lideranças globais de grande prestígio, como o presidente francês, François Mitterrand, ou o Papa João Paulo II. No caso específico de Collor, pode-se argumentar, em consonância com a leitura de que os efeitos estruturais impactaram diretamente sobre os temas e estratégias posteriores da política externa, que sua agenda de campanha em questões internacionais foi inteiramente moldada pelos "ventos do mundo". Em outras palavras, tudo o que o candidato do PRN apresentou ao longo da campanha representava reações - em geral, pouco elaboradas - ao que o mundo demandava do Brasil e que eram, em certo sentido, pontos críticos à credibilidade internacional brasileira.

No caso da longa viagem de Collor à Europa, descrita a seguir, estes três elementos faziam-se presentes: (1) como se tratava de um político relativamente desconhecido e sem grande lastro partidário ou eleitoral em plano nacional - característica muitas vezes

estimulada pelo próprio candidato, de modo a apresentar-se como uma novidade -, os contatos internacionais serviram-lhe para constituir sua própria identidade política, para além do chavão "caçador de marajás". Ora apresentando-se com um social-democrata europeu, ora vestindo a túnica do neoliberalismo britânico, Collor apropriava-se de imagens - mais do que de ideias - para fins exclusivamente eleitorais; (2) mesmo que nunca tenha admitido ir ao exterior buscar apoio político, ao contrário do que fizeram Brizola ou Lula em seus contatos entre os socialistas europeus, o candidato do PRN apresentou-se, às lideranças mundiais, 
como aquele que poderia conduzir o Brasil no caminho da modernidade - oferecendo-lhes, para tanto, propostas relativamente ousadas (embora ingênuas, por vezes) em temas que estavam na crista do debate internacional, como ecologia ou integração regional; (3) mais do que simplesmente uma questão de identidades políticas, parece ter havido, no decurso da campanha de 1989, uma espécie de disputa por prestígio, isto é, uma corrida entre os principais candidatos para ver quem era mais bem aceito entre os grandes nomes das relações internacionais.

As consequências da campanha presidencial, é claro, serão sentidas na formação do governo Collor, uma vez eleito. Internacionalmente, esperava-se que o novo presidente, que tanto havia agradado (ou buscado agradar) as lideranças europeias e merecido manchetes internacionais enquanto ainda era candidato, pudesse cumprir com a promessa de levar o Brasil ao Primeiro Mundo. Não se tratava de tarefa fácil, especialmente porque as condições políticas e econômicas do período de transição presidencial, além de delicadas já na origem, deterioravam-se a passos largos. O objetivo deste capítulo é reconstruir a narrativa da corrida presidencial de 1989, a partir das questões internacionais, e mostrar como os compromissos assumidos por Collor no percurso contribuíram para moldar a política externa de seu governo.

\subsection{O candidato Collor vai à Europa em busca de identidade política}

"Preciso sair uns dias do centro do tiroteio nacional". O pré-candidato à presidência da República, Fernando Collor, justificava, assim, sua viagem à Europa, a ser realizada em algumas semanas. Era maio de 1989 e Collor, que havia se apresentado como uma alternativa na corrida presidencial um mês antes, já abria 13 pontos de vantagem nas pesquisas eleitorais com relação ao segundo colocado, Leonel Brizola ${ }^{88}$. Os ataques ao candidato do PRN subiam na mesma proporção.

Não eram poucos que encaravam com estranheza a ascensão meteórica de Collor. Pelos resultados do Ibope, o candidato do PRN passara de 5\% das intenções de voto, em 5 de fevereiro, para nada menos que $32 \%$ no início de maio ${ }^{89}$. No dia da divulgação do resultado da pesquisa Datafolha, 28 de maio, em que o desconhecido governador de Alagoas aparecia com 30\% das intenções de voto, dois colunistas da Folha de São Paulo atacaram sua candidatura a partir de críticas semelhantes. Clóvis Rossi sugeria que o "fenômeno Collor" era produto da combinação de dois fatores básicos, a “desinformação de uma parcela

\footnotetext{
${ }^{88}$ FSP, 28 de maio de 1989, p. 6.

${ }^{89}$ Veja, 17 de maio de 1989, p. 40.
} 
substancial da sociedade brasileira" e o "desencontro profundo e generalizado para com os políticos" " Carlos Eduardo Lins da Silva, por sua vez, tratava Collor como "o candidato de plástico" no contexto de uma corrida presidencial marcada pela "disputa para ver quem consegue ser mais vazio de conteúdo" ${ }^{91}$.

Havia certo fundamento no que diziam. Apresentando-se como candidato jovem e renovador, Collor conseguiu granjear apoios e popularidade pelo fato de expressar o anseio generalizado de combate à corrupção e aos desmandos da máquina pública. Seus esforços de autopromoção eram estudados e, por vezes, estridentes, o que só reforçava a impressão de que havia pouca substância por trás do tom combativo de seus discursos. Mas o candidato soube, como poucos, adaptar-se às transformações pelas quais passava o mundo, ao fim da década de 1980. A longa viagem que faria à Europa, mais do que simplesmente uma decisão de esquivar-se dos ataques políticos que vinha sofrendo, também corporificava um cosmopolitismo que, no entendimento de Collor, estava em sintonia com os anseios por um Brasil moderno.

Abraçar precocemente o "thatcherismo", uma alternativa privatista e modernizante em ascensão ao redor do mundo, foi a maneira que o governador alagoano encontrou de distinguir-se, pela direita, da "geleia geral" - termo habilidosamente empregado por André Singer - que se tornara o debate da sucessão presidencial e, ao mesmo tempo, conectar-se às tendências internacionais da era da globalização ${ }^{92}$. Pela esquerda, buscava aproximar-se dos socialistas espanhóis - que haviam empreendido a mais bem-sucedida experiência de pacto social - e costurar um "Pacto de Moncloa" à brasileira ${ }^{93}$.

Enquanto os outros candidatos construíam ou consolidavam suas identidades políticas a partir de referências do passado, herdadas dos tempos de Getúlio ou dos militares, Collor proponente de uma espécie de antipolítica que lhe serviu como impulso eleitoral - valeu-se dos vínculos internacionais que costurava como seu cartão de visitas. Por isso mesmo, aproveitou os dias que passaria fora do país para colecionar oportunidades fotográficas e apresentar-se, tanto para o público doméstico quanto para os espectadores externos, como a "nova cara" do Brasil.

Fernando Collor não foi o único a realizar viagens internacionais como parte da campanha à sucessão, mas talvez tenha sido o que lhes conferiu maior importância, uma vez que faziam parte da construção de seu discurso modernizante. A agenda dos demais

\footnotetext{
${ }^{90}$ Rossi, Clóvis. "Collor, visto de perto”. FSP, 28 de maio de 1989, p. A-2.

${ }^{91}$ Lins da Silva, Carlos Eduardo. "O candidato de plástico". FSP, 28 de maio de 1989, p. A-2.

${ }^{92}$ Singer, André. “Acabou a geléia”. FSP, 23 de julho de 1989, p. A-2.

93 O Globo, "Collor: 'Pacto de Moncloa' à brasileira", 1 de junho de 1989, p. 3.
} 
candidatos, em contraste, era eminentemente defensiva. Na viagem de Lula à Europa, em março de 1989, a principal pauta trazida na conversa com políticos socialistas na França e na Itália $^{94}$ girava em torno do temor que o candidato tinha da possibilidade de, caso eleito, ocorrer uma manobra para impedir sua posse. O candidato do PT defendeu a formação de uma "frente democrática" de governos e partidos europeus para preservar o processo democrático no Brasil ${ }^{95}$. No início de julho, o candidato do PDS, Paulo Maluf, passou três dias na Bolívia reunindo-se com diversos grupos políticos e representantes da sociedade civil $^{96}$. Seu intuito principal era conhecer, em detalhes, a concepção e implementação do plano econômico do ministro Gonzalo Sánchez de Lozada, responsável por conter a hiperinflação do país, avaliada em $28.000 \%$ entre 1983 e $1985^{97}$.

O principal candidato da esquerda, Leonel Brizola, também realizou viagem à Europa. Passou por Portugal, França e Suécia, encontrando-se com os presidentes Mário Soares, em Lisboa, e François Mitterrand, em Paris. Tratou, com ambos, de temas caros à política brasileira, como a questão da dívida externa e do meio ambiente - assunto particularmente sensível às autoridades francesas, que vinham aumentando o tom contra a depredação ambiental no Terceiro Mundo ${ }^{98}$. Com relação aos juros da dívida, Brizola apoiou iniciativa francesa de redução das taxas de juros sobre os empréstimos à Polônia e sugeriu que esse modelo poderia ser aplicado no caso brasileiro. No tocante à ecologia, o candidato do PDT prometeu criar uma secretaria exclusiva para assuntos ambientais, recebendo garantias do presidente francês de que a soberania dos países não seria colocada em risco em função das preocupações ambientais globais. Em Estocolmo, participou do Congresso da Internacional Socialista (IS), do qual se elegeu vice-presidente. Conduzindo o PDT a membro efetivo da IS, Brizola ampliaria suas possibilidades de discutir problemas em nível global, como dívida externa e ecologia ${ }^{99}$.

\footnotetext{
${ }^{94} \mathrm{O}$ giro de Lula ficou circunscrito a Itália, Vaticano e França. O candidato foi recebido pelo Papa João Paulo II, no dia 2 de março, mas o contato limitou-se a um rápido aperto de mão - que refletiu o momento delicado pelo qual passavam as relações entre o Vaticano e a Igreja progressista do Brasil, identificada com o PT. Na Itália, Lula encontrou-se com representantes da Confederação Geral dos Trabalhadores Italianos, de linha comunista. Em Paris, Lula encontrou-se com o ex-primeiro ministro e presidente da Assembleia Nacional, o socialista Laurent Fabius, além do primeiro-ministro francês, Michel Rocard, o secretário-geral da Confederação Francesa Democrática do Trabalho (CFDT), Jean Kaspar,

${ }^{95}$ OESP, "Papa evita contato prolongado com Lula", 3 de março de 1989, p. 6; "Lula procura garantia para a posse", 4 de março de 1989, p. 4.

${ }_{97}$ OESP, "Maluf elogia plano da Bolívia e pede orações", 13 de julho de 1989, p. 7.

97 Para mais detalhes, ver http://www.earthinstitute.columbia.edu/sitefiles/file/about/director/documents/AERBolivia87.pdf

${ }^{98}$ FSP, "Brizola vê Mitterrand e reclama dos juros da dívida externa", 20 de junho de 1989, p. A-4.

99 FSP, "Brizola é eleito vice da Internacional Socialista", 22 de junho de 1989, p. A-6.
} 
Embora a turnê europeia de Brizola tenha sido propositiva, sua motivação para cruzar o Atlântico estava diretamente ligada a Collor, seu principal concorrente. Com viagens marcadas para a mesma semana, ambos envolveram-se numa espécie de "disputa de prestígio" entre os mais importantes líderes social-democratas ${ }^{100}$. Antecipando-se ao exgovernador de Alagoas, Brizola apressou-se para marcar audiências de alto nível, valendo-se da ampla rede de lideranças socialistas que havia construído nos tempos de exílio, para ofuscar a passagem de seu rival pela Europa. A propósito dessa disputa, escreveu Tales Faria que "Brizola deve ter marcado pontos esta semana na corrida [presidencial] (...). Conseguiu dividir com Collor igual espaço no noticiário [e] abafou, até agora, todo o trabalho de marketing que a assessoria de Collor havia preparado para sua turnê pela Europa"101.

A queda de braço com Brizola não impediu que o candidato do PRN colhesse dividendos em solo europeu. Tratava-se, afinal, de viagem muito mais ambiciosa e longa, em que seriam cobertos sete países em quase vinte dias. Durante seu período no exterior, fez da política externa um dos pilares de seu discurso, apresentando-se como contraponto a um governo que havia contribuído, no entendimento de alguns, para uma corrosão (quase terminal) da imagem internacional do país. Seu diagnóstico convergia com aquilo que William Waack havia escrito à época:

\footnotetext{
"Ninguém mais, dentro ou fora do Brasil, atribui a Sarney qualquer capacidade (e alguns nem sequer a intenção) de levar o país a resolver com a comunidade internacional alguns de seus problemas: o financeiro, o comercial e o ecológico. E por melhor que sejam redigidos os discursos de experientes diplomatas brasileiros como os representantes em Nova York ou Genebra, Moscou ou Washington - tornase difícil escapar à convicção geral de que nem sequer o Itamaraty conseguiu preservar sua imagem intocada",102
}

Foram exatamente os problemas econômico, financeiro e ecológico que Collor buscou atacar em seus encontros de alto nível na Europa, iniciados no dia 19 de junho. Preocupava-o, em particular, como o Brasil se tornaria uma economia competitiva e aberta, após a derrocada do modelo nacional-desenvolvimentista que prevalecera até o fim daquela década; como o país poderia renegociar sua dívida externa e abrir caminho para a retomada do crescimento; como se poderiam superar as críticas internacionais com relação à preservação ambiental e à questão amazônica, mais especificamente.

\footnotetext{
${ }^{100}$ OESP, "Brizola e Collor buscam apoio na Europa”, 20 de junho de 1989, p. 6.

${ }^{101}$ Faria, Tales. "Raposas à solta". FSP, 21 de junho de 1989, p. A-2.

102 Waack, William. "De Paris a Mombaça, tudo é festa". OESP, 25 de julho de 1989, p. 2.
} 
Tratava-se, contudo, de esboços de ideias, muitas das quais refletiam não somente voluntarismo como, também, certa ingenuidade. Collor buscava blindar-se de possíveis derrapadas confessando ser "um homem do Nordeste, com uma visão pouco aprofundada da realidade internacional". Aparentemente, tinha menos interesse em granjear apoios e mais vontade de estabelecer contatos com as lideranças europeias, em busca de um ponto de sustentação ideológica que pudesse ser incorporado à sua identidade política. Mas não havia clareza sobre que orientação tomaria Collor, quando voltasse ao Brasil. Questionado, na viagem, se suas ideias convergiam com a social-democracia, o candidato negou e se autodenominou um "reformista de centro" - interessado tanto nos socialistas franceses e portugueses quanto nos liberais britânicos. Chegou até a elogiar o modelo econômico de Gorbachev, dizendo que ele "se compatibiliza com minha base programática"103.

Na primeira parada, em Lisboa, Collor reuniu-se com o primeiro-ministro português, Cavaco Silva. Ambos debateram, no encontro, o papel que Portugal poderia desempenhar como eixo fundamental da necessária aproximação entre os países da América Latina e a Comunidade Econômica Europeia. O candidato, que tentava vender domesticamente a reputação de "caçador de marajás", também sugeriu que criaria, se eleito, uma procuradoria especial para combater crimes de corrupção ${ }^{104}$. Collor também almoçou com o presidente português, Mário Soares. À ocasião, propôs a criação de um "imposto sobre poluição", para taxar os países que poluem o meio ambiente. Baseada na tese do professor Samuel Isaac Benchimol $^{105}$, a proposta sugeria que um organismo designado pelas Nações Unidas cobrasse esse imposto dos países de acordo com a carga de poluição jogada nos rios, mares ou ar. Os fundos arrecadados deveriam ser revertidos para países que tivessem projetos consistentes de combate à poluição. Confrontado com a afirmação de que a ONU não é um governo e que não pode, por conseguinte, impor multas ou impostos, Collor tergiversou: "se houvesse algum órgão com poder para isso, seria exatamente a ONU"106.

No dia 21 de junho, o ex-governador rumou para Paris, onde desembarcou ainda sem saber se seria recebido por François Mitterrand. Collor foi o quarto candidato a visitar a capital francesa no contexto da sucessão presidencial, sendo precedido por Ulysses, Lula e Brizola. Foi o primeiro, contudo, a ser criticado pela imprensa local antes mesmo de chegar à França: numa reportagem sobre o "fenômeno Collor", o periódico Le Monde chamou o

\footnotetext{
103 OESP, "Em Portugal, espaço na imprensa”, 20 de junho de 1989, p. 7.

${ }^{104}$ FSP, "Collor quer criar procuradoria para corrupção", 20 de junho de 1989, p. A-5.

105 Entrevista de Collor ao programa Roda Viva, agosto de 1989. Disponível em http://www.rodaviva.fapesp.br/materia busca/829/collor/entrevistados/fernando_collor_de_mello_1989.htm

${ }^{106}$ FSP, “Collor quer taxar países poluidores", 21 de junho de 1989, p. A-6.
} 
candidato de "vazio", "vago de ideias", "filho dourado da oligarquia" e uma reprodução de um "fenômeno acontecido há 30 anos", em referência à eleição de Jânio Quadros ${ }^{107}$. Sem agenda por praticamente dois dias - o primeiro-ministro Rocard não poderia encontrá-lo imediatamente, já que o candidato havia antecipado a viagem possivelmente em função das movimentações de Brizola - Collor aproveitou parte de seu tempo livre para conversar com jornalistas sobre seus projetos de política externa e dirimir a imagem negativa com a qual pousara em solo francês. Não à toa, o primeiro encontro foi com o diretor do Le Monde, André Fontaine. Mas Collor também falou com diversos correspondentes brasileiros que cobriam sua viagem.

Nas conversas, buscou explicar em detalhes sua proposta sobre a renegociação da dívida externa, na qual tiraria o aval do governo sobre os débitos contraídos por estados e municípios. Além disso, revelou que uma de suas sugestões aos líderes europeus seria um "perdão substancial" da dívida. Esmiuçou, por fim, seu plano do imposto internacional aos países poluidores, segundo o qual seria calculada uma tarifa de US\$ 100 por tonelada/ano de emissão poluente a ser cobrada das nações, com mediação da ONU. A Folha de São Paulo desqualificou a ideia como uma proposta inviável: somente de Estados Unidos, União Soviética e China seriam cobrados, respectivamente, US\$ 120 bilhões, US\$ 75 bilhões e US\$ 50 bilhões anuais. "Precisa ser muito ingênuo para imaginar que pelo menos estes três países - membros do Conselho de Segurança da ONU, com direito a veto - estejam prontos a entregar essa soma, anualmente!", ironizou o periódico ${ }^{108}$.

Não foi a única gafe que Collor cometeu. Após encontro com Valéry Giscard d'Éstaing, o candidato fez referência ao ex-presidente francês (de centro-direita) como um "social-democrata", categoria em que também incluiu a primeira-ministra britânica, Margaret Thatcher. Collor também exaltou as privatizações realizadas pelo socialista Mitterrand, sendo que o então presidente não só havia interrompido as vendas de estatais, como nacionalizara alguns setores da economia em seu mandato. Ao ser perguntado sobre as razões que o levaram a buscar apoio junto aos líderes europeus, Collor foi taxativo: "só me interessa o apoio da sociedade civil brasileira" ${ }^{109}$. Tudo indicava que, a despeito da determinação em se apresentar como um candidato cosmopolita, as propostas levadas à Europa eram balizadas pelo mesmo voluntarismo que caracterizava sua campanha desde o princípio.

\footnotetext{
${ }^{107}$ FSP, "Collor chega a Paris criticado pelo 'Le Monde"”, 21 de junho de 1989, p. A-6.

${ }^{108}$ FSP, "Collor faz proposta inviável para ecologia", 23 de junho de 1989, p. A-6.

109 Watkins, Thayer. "Privatization in France", $\quad$ disponível em http://www.sjsu.edu/faculty/watkins/privFrance.htm
} 
A única reunião de alto nível que Collor conseguiu na França foi com o primeiroministro Rocard, no dia 23 de junho. Levou à ao Palácio Matignon uma versão traduzida de sua proposta do imposto sobre poluição, mesmo tendo sido alertado por jornalistas, poucos minutos antes da audiência, que os valores sugeridos originalmente eram impraticáveis, sobretudo aos grandes poluidores globais. Collor admitiu que não havia realizado os cálculos dos montantes finais, mas que o valor proposto de US\$ 100 por tonelada/ano serviria apenas como um "elemento de partida". Ao sair da reunião com Rocard, o candidato disse que o primeiro-ministro havia recebido a proposta "com simpatia", embora não pudesse aceitá-la prontamente porque precisaria, antes de tudo, submetê-la a setores da sociedade francesa ${ }^{110}$.

Outro tema central abordado na conversa com Rocard dizia respeito à dívida externa brasileira. Ao contrário das expectativas, o candidato do PRN não apresentou a proposta da retirada do aval das dívidas setoriais, sobre a qual comentara longamente aos jornalistas no dia anterior. Ainda assim, Collor disse haver "aprofundado" a discussão sobre a dívida externa, sobretudo no tocante a suas implicações sociais, e obtido o apoio do primeiroministro na busca do reescalonamento da dívida e no repúdio às teses "monetaristas", de alto custo social, que prevaleciam entre os operadores do Fundo Monetário Internacional até a eleição do francês Michel Camdessus, em 1987. O máximo que o candidato conseguiu extrair de Rocard, entretanto, foi uma vaga manifestação de simpatia ao "terceiro-mundismo" "111.

As preocupações de Collor começavam a mudar após a passagem pela França. A viagem estava sendo conturbada, em função das questões de agenda, e a exposição nos meios de comunicação haviam revelado diversas incongruências nas propostas "modernas" do candidato. Do outro lado do oceano, brigas internas corroíam a já frágil base partidária do PRN, que acabava de perder algumas lideranças importantes em Santa Catarina e no Mato Grosso do Sul. Ao mesmo tempo, eclodia um escândalo potencialmente destrutivo à sua candidatura: descobriu-se que Collor havia contratado, na última semana de seu mandato como prefeito de Maceió, nada menos que 1.463 novos servidores, sem concurso, para a Secretaria de Educação.

Por fim, rumores de uma candidatura "surpresa" poderia colocar a vantagem de Collor em xeque. Aos 72 anos, especulações de que Jânio Quadros sairia candidato à presidência traziam um componente adicional de ansiedade à (já pulverizada) corrida eleitoral do fim do ano. Esse foi o foco da primeira entrevista concedida pelo candidato ao desembarcar na Itália. Demonstrando confiança em sua candidatura, Collor negou a jornalistas que acreditasse no

\footnotetext{
${ }^{110}$ FSP, "Collor diz que Rocard simpatiza com imposto", 24 de junho de 1989, p. A-11.

${ }^{111}$ OESP, “Collor discute dívida com Rocard”, 24 de junho de 1989, p. 5.
} 
retorno de Jânio e arrematou: "a candidatura Collor tem uma dimensão que não é a mesma das demais, que pertencem ao sistema e já foram metabolizadas e desmetabolizadas pelo próprio sistema. A minha candidatura é anti este sistema que está aí"112.

Em Roma, o ex-governador alagoano encontrou-se com Amintore Fanfani, ministro do Orçamento e da Programação Econômica. Também teve uma audiência com o vice-presidente do Conselho de Ministros, Gianni de Michelis, e com o ministro dos Negócios Estrangeiros, Giulio Andreotti. Pela primeira vez, Collor não expôs aos jornalistas a pauta das conversas e de suas propostas junto às lideranças italianas. Preferiu, em vez disso, frisar que seu único objetivo era o de conhecer as opiniões dos políticos europeus. A única menção à conversa com Andreotti, por exemplo, foi feita pelo próprio ministro, que disse a correspondentes brasileiros que apoiava a ideia de Collor de "tornar o pagamento do débito do Brasil mais leve" e que o candidato tinha "ideias claras" sobre ecologia ${ }^{113}$. Collor tampouco reagiu às acusações que haviam sido feitas sobre as contratações em Maceió, deixando para seu assessor de imprensa, Cláudio Humberto Rosa e Silva, a explicação aos jornalistas. Além de dizer que as listas de contratações excessivas foram "enxertadas" pelos vereadores da capital alagoana, Cláudio Humberto fez questão de frisar que "Alagoas é um capítulo encerrado", como forma de evitar novos desgastes e não tirar o foco da viagem de Collor ${ }^{114}$.

No dia 26 de junho, o candidato do PRN dirigiu-se ao Vaticano para um encontro com o papa João Paulo II. O sumo pontífice já tinha recebido Lula alguns meses antes, mas sem dar-lhe tratamento especial. Collor, ao contrário, conseguiu uma audiência privada articulada, mesmo fora do prazo, pelo embaixador brasileiro no Vaticano, Arinos Filho, com a devida intercedência do cunhado de Collor, Marcos Coimbra, então embaixador em Atenas ${ }^{115}$. Como estava em seu segundo casamento, o ex-governador não contou com a companhia sua mulher, Rosane, aconselhada por diplomatas brasileiros a não acompanhá-lo ${ }^{116}$. Apesar disso, o encontro em si - "a audiência mais importante desta viagem", segundo Collor - foi um sucesso, sobretudo após a negativa de Mitterrand em recebê-lo em Paris, dias depois de uma

\footnotetext{
${ }^{112}$ FSP, "Nada abalará a candidatura", 24 de junho de 1989, p. A-11.

${ }^{113}$ FSP, "Collor vai encontrar o Papa", 25 de junho de 1989, p. A-8.

${ }^{114}$ FSP, "Fernando Collor contesta contratação na Femac", 25 de junho de 1989, p. A-8.

${ }^{115}$ Veja, 05 de julho de 1989, p. 36.

${ }^{116}$ Inicialmente, Collor havia dito que Rosane o havia acompanhado. Na coluna "Painel", da FSP, lia-se uma nota com informação divergente daquela oferecida pelo candidato no dia anterior. "À audiência, entretanto, não pôde comparecer a mulher de Collor, Rosane. O casamento deles, feito uma certa Igreja Católica Brasileira, já que Collor é divorciado, não é reconhecido pela Igreja Apostólica Romana. Rosane já havia se preparado, comprando um véu preto em uma loja romana no dia anterior, quando foi avisada pelo Itamaraty que sua presença poderia trazer constrangimento" (28 de junho de 1989, p. A-4). As informações foram confirmadas na Revista Veja, dias depois (5 de julho de 1989, p. 36). Meses mais tarde, circulou uma foto do encontro entre Collor e o papa em que Rosane aparecia.
} 
longa conversa com Brizola. Na queda de braço simbólica das viagens internacionais, o candidato do PRN ganhava a dianteira: afinal, muito mais gente sabia quem era João Paulo II do que o presidente da França. Aos jornalistas, o candidato relatou que trataram dos problemas atuais do Brasil, como a "excessiva concentração de renda e o estado de miséria absoluta" e que pedira uma bênção para o Brasil e a América Latina. Seguiu-se à conversa com o papa um encontro com o diretor da FAO, Eduard Sauma, em que falaram sobre projetos de irrigação no Nordeste brasileiro ${ }^{117}$.

Em seu retorno à Itália, no dia seguinte, Collor encontrou-se com o secretário-geral do Partido Socialista Italiano, Bettino Craxi, e com o representante de relações exteriores do Partido Comunista Italiano, Giorgio Napolitano. Tratou, com o primeiro, dos temas ecológicos e financeiros que preocupavam o Brasil, conquistando a solidariedade do socialista. Após o encontro, considerado o "ponto alto" de sua passagem pela capital italiana, Collor reiterou a afinidade entre seu próprio partido, o PRN, e os partidos socialistas europeus: "O socialismo europeu busca a eficiência da máquina do Estado, busca sempre as necessidades básicas, o bem-estar social e, nesse ponto, estamos de acordo". Com Napolitano, fez uma reunião mais protocolar, em que o comunista declarou que o entendimento de seu partido era com o candidato Lula ${ }^{118}$.

Enquanto Collor rumava a Bonn, capital da Alemanha Ocidental, o jogo doméstico ficava cada vez mais intenso. Se, por um lado, as acusações contra suas contratações incomuns na prefeitura de Maceió foram parcialmente ofuscadas pela descoberta de problemas mais graves em contratações no Rio de Janeiro, no governo Brizola, outros candidatos passam a ameaçar diretamente Collor naquilo que ele tinha de mais singular: seu discurso modernizante. Ao longo daquela semana, Maluf havia repetido diversas vezes que o Brasil precisava de uma "Thatcher de calças", oferecendo-se a desempenhar este papel ${ }^{119}$. Mas o candidato com maior potencial de neutralizar a retórica "collorida" era Mário Covas. Depois de quase uma semana de expectativa, ele finalmente fez seu discurso de lançamento de campanha no dia 28 de junho, saudado pelos colegas tucanos como "discurso de estadista". Abandonando a retórica estatista e nacionalista que havia caracterizado, em algum sentido, sua trajetória política, Covas atacou Collor ("não me submeterei (...) a qualquer jogo de aparência ou a truques de persuasão publicitária. Apresento-me ao povo brasileiro sem maquiagem, como sempre fiz"), reiterou a necessidade da política para a democracia e, mais

\footnotetext{
${ }^{117}$ FSP, "Collor desafia adversários a se unirem contra ele", 27 de junho de 1989, p. A-6.

${ }^{118}$ FSP, "Collor vê o PRN próximo do socialismo europeu", 28 de junho de 1989, p. A-7.

${ }^{119}$ FSP, "Persistente, Maluf insiste em chegar à Presidência”, 30 de junho de 1989, p. A-6.
} 
importante, abraçou as teses modernizantes que prevaleciam à época - e que, até então, eram identificadas com o adversário do PRN: “o Brasil não precisa apenas de um choque fiscal. Precisa, também, de um choque de capitalismo, um choque de livre iniciativa, sujeita a riscos e não apenas a prêmios"120. Em relação à política externa, Covas ressaltou que "o país deve participar da nova ordem econômica internacional" ${ }^{\text {121 }}$, em referência às forças da globalização que, aparentemente, se tornavam irresistíveis.

Em meio aos rápidos encontros com o chanceler alemão, Helmut Kohl, e o ministro das Relações Exteriores, Hans Dietrich Genscher, analistas políticos e correligionários do PRN já discutiam a efetividade de uma viagem ao exterior tão longa. O encontro com os líderes germânicos não foi capaz de atrair a atenção do público como os anteriores. A jornalistas, Collor disse que esses contatos lhe dariam mais força para defender os interesses brasileiros com os europeus ${ }^{122}$, mas a agenda do candidato na Europa já se tornara repetitiva: meio ambiente e dívida externa dos países do Terceiro Mundo, sem nenhum acréscimo ou novidade. A coluna de Newton Rodrigues, contudo, faz um balanço favorável da viagem até aquele momento:

\footnotetext{
"Tecnicamente, no esporte, como na política, é desaconselhável chegar ao máximo de desempenho antes do momento decisivo. Collor estava correndo esse risco e, desse ponto de vista, a folga lhe foi benéfica. Quanto ao chamado fracasso de entrevistas resume-se, até agora, a não ter sido recebido por Mitterrand e pelo primeiro-ministro da Itália. A lista de encontros inclui, entretanto, Mário Soares, Cavaco, Rocard, Bettino Craxi, Kohl e o papa (...). Nenhum desses personagens vota no Brasil, é verdade, o que vale para todos os casos e todos os candidatos. Por outro lado, no Brasil, algumas adesões importantes ocorreram no mesmo período" ${ }^{\text {"123 }}$
}

De volta da rápida passagem pela Alemanha, a última parada oficial de Collor em solo italiano foi em Bologna, onde se reuniu com Romano Prodi, presidente do Instituto da Reconstrução Industrial. Um dos maiores conglomerados estatais do mundo, o IRI foi responsável pela recuperação econômica de empresas italianas e por sua posterior privatização, sendo um dos pilares do "milagre econômico" do país nas décadas de 1950 e $1960^{124}$. O candidato, acompanhado de sua assessora econômica, Zélia Cardoso de Mello, tratou de um aspecto importante de seu futuro programa de governo, as privatizações de estatais brasileiras. Queria ouvir de Prodi a melhor maneira de vender estatais deficitárias sem

\footnotetext{
${ }^{120}$ OESP, "Discurso de Covas empolga Senado", 29 de junho de 1989, p. 4.

${ }^{121}$ FSP, "Covas abandona discurso nacionalista e estatizante", 30 de junho de 1989, p. A-10.

122 OESP, "Collor toma aula de privatização", 30 de junho de 1989, p. 5.

${ }^{123}$ Rodrigues, Newton. "Viagem de candidato", FSP, $1^{\circ}$ de julho de 1989, p. A-2.

${ }^{124}$ Araujo, Motta. "A história do Istituto per la Riconstruzione Industriale", 15 de maio de 2014. Disponível em http://jornalggn.com.br/noticia/a-historia-do-istituto-per-la-ricostruzione-industriale
} 
prejudicar o patrimônio público. "A modernização e o reaparelhamento do Estado é muito importante para nossa política econômica”, disse Collor, na saída do encontro. Sua ideia era continuar debatendo o tema com empresários e economistas de outros países europeus ${ }^{125}$.

A próxima parada de Collor era Madri, onde se encontrou, numa apertada agenda de um só dia, com o rei Juan Carlos, com o ex-primeiro-ministro Adolfo Suárez e com o atual, Felipe González. Na pauta das conversas, além da dívida externa e da questão ecológica, o candidato retomou uma discussão que havia iniciado em Portugal: a integração da América Latina com os países europeus. As nações ibéricas eram consideradas portas de entrada para o aprofundamento das relações latino-americanas com o velho continente ${ }^{126}$. Collor sugeriu uma possível explicação em entrevista ao programa Roda Viva, um mês mais tarde, ao ponderar que a integração era necessária "já que somos um reflexo do continente europeu"127. Por trás de uma formulação primária, pode-se depreender uma interpretação de fundo de que, a despeito das enormes diferenças que nos separavam das nações mais desenvolvidas da Europa, o Brasil guardava mais semelhanças com os ibéricos, de quem éramos reflexo, do que com países do Terceiro Mundo - dos quais Collor ainda não havia manifestado o desejo de se distanciar, mas que passaria a negar, em termos mais contundentes, a partir de sua eleição.

Em Londres, último destino de Collor antes de retornar ao Brasil, ele se encontrou com a primeira-ministra britânica, Margaret Thatcher, em sua residência oficial na Downing Street 10 - naquilo que foi qualificado como uma "reunião de cortesia" pelo porta-voz do governo britânico. "Concordamos em quase tudo, menos na questão da dívida externa", disse o candidato a jornalistas. Segundo ele, Thatcher permaneceu irredutível quanto à necessidade de pagamento integral da dívida externa, não aceitando o pedido de Collor para que a primeira-ministra utilizasse sua influência na busca de apoio dos países ricos a iniciativas para reduzir o encargo dos débitos das nações em desenvolvimento. Por outro lado, o candidato reportou que Thatcher elogiou a proposta de ampla desestatização da economia brasileira que lhe foi descrita, além de considerar a ideia do Imposto Mundial sobre a Poluição Ambiental oportuna, prometendo seu apoio aos esforços para viabilizá-la no âmbito das Nações Unidas $^{128}$.

Após a reunião de meia-hora com a "dama de ferro", Collor participou de almoço oferecido, em sua homenagem, pela Câmara Brasileira de Comércio na Grã-Bretanha, que contou com representantes do Ministério do Comércio e da Indústria, das grandes companhias

\footnotetext{
${ }^{125}$ OESP, "Collor toma aula de privatização", 30 de junho de 1989, p. 5.

${ }^{126}$ OESP, “Collor se reúne com Juan Carlos", 04 de julho de 1989, p. 4.

${ }^{127} \mathrm{http}$ ://www.rodaviva.fapesp.br/materia/829/entrevistados/fernando_collor_de mello_1989.htm

128 FSP, "Collor encontra Thatcher e diverge sobre dívida", 05 de julho de 1989, p. A-7.
} 
e de quase todos os bancos britânicos, além de gerentes de empresas brasileiras com escritórios em Londres. Em seu discurso, em inglês, Collor afirmou que o "Brasil não pretende o isolacionismo", mas sim "integrar-se à economia mundial de modo soberano e compatível com o necessário progresso econômico e o desejável desenvolvimento social" "129. Ao ser saudado por sir William Harding, presidente da Câmara de Comércio, como o "galã latino-americano que derreteu o coração da Dama de Ferro", Collor fixava, diante de um público europeu, a imagem de estadista que queria construir no exterior ${ }^{130}$.

Os dezoito dias de ausência dividiram assessores. Na opinião de Cleto Falcão (PRNAL), chefe da assessoria política do candidato, apesar dos bons contatos políticos mantidos ao redor da Europa, abriu-se um flanco na candidatura, uma vez que pouco espaço midiático lhe foi garantido durante o período. "Só o candidato consegue criar fatos para a imprensa", completou Paulo Octávio, também dirigente do PRN nacional. O jornalista Carlos Eduardo Lins da Silva faz uma avaliação mais ponderada sobre a viagem, considerando-a bem sucedida, seja na contribuição para a formação de uma imagem de estadista, seja como válvula de escape diante das fortes pressões que se colocavam a um candidato que "estava tão por cima que o desgaste era inevitável na sequência”. O terreno perdido, para ele, era menor do que se ele tivesse ficado no Brasil, sendo bombardeado por perguntas constrangedoras e movimentações igualmente problemáticas, como o desmantelamento de algumas bases regionais do PRN. Conclui Lins da Silva:

\begin{abstract}
"De longe, Collor se exibiu com papa, rei, primeiros-ministros (...). [C]onseguiu se reunir com mais chefes de Estado do que qualquer um de seus concorrentes. Alguns, como João Paulo $2^{\circ}$ e Juan Carlos, podem até render algum dividendo eleitoral num país tão fascinado por igreja e nobreza, como é o Brasil. O encontro com Thatcher serviu para consolidar a falsa imagem de que Collor é o representante do liberalismo extremado (...), reforça a impressão de que ele é o Thatcher brasileiro" ${ }^{\text {"131. }}$.
\end{abstract}

\title{
2.1.1. A disputa pelo centro
}

De volta ao Brasil, Collor encontrou uma situação doméstica conturbada. Sua base partidária não deslanchava, os empresários permaneciam céticos em relação ao candidato, e seus concorrentes já se posicionavam com mais clareza no contexto da corrida presidencial. $\mathrm{O}$ discurso de Covas ao senado foi visto como um divisor de águas em sua campanha, pois representou um movimento para ocupar o centro do espectro político - falando, por exemplo,

\footnotetext{
${ }^{129}$ OESP, “Collor vê Thatcher e tem boa recepção em Londres”, 05 de julho de 1989, p. 4.

${ }^{130}$ FSP, "Collor encontra Thatcher...".

${ }^{131}$ Lins da Silva, Carlos Eduardo. "Ausência veio na hora certa”, FSP, 04 de julho de 1989, p. A-4.
} 
em "choque de capitalismo" - sem perder espaço entre os eleitores de uma esquerda mais moderada. Aureliano Chaves, do PFL, também oficializou sua candidatura poucos dias antes da volta de seu adversário do PRN, dirimindo as inseguranças quanto a um potencial retorno de Jânio Quadros, mas consolidando-se como uma alternativa à direita. Não parece coincidência que, desde a chegada a Madri, Collor tenha se definido, reiteradas vezes, como um "reformista de centro"132 - como fizera em Portugal -, na esperança de não deixar o centro político ser ocupado por alguma outra candidatura. No entanto, com o centro já preenchido por variadas forças mais à esquerda - como Brizola e Lula - e com um discurso "moderno", como Covas, o candidato do PRN seria forçado a caminhar para a direita como forma de se distinguir daqueles que poderiam minar sua liderança na campanha.

Poucos dias depois do retorno ao Brasil, Collor ainda arriscou uma alternativa: venderse como herdeiro político de Juscelino Kubitschek, na esteira do apoio de sua filha, a deputada federal do PMDB Márcia Kubitschek. Em vão: depois de Collor declarar, em Belo Horizonte, que estava "reconquistando o sentimento de mineiridade que a herdeira direta de JK me transfere", a própria Márcia foi rápida em rebater as declarações do candidato: "Não vamos confundir as coisas: o Juscelino foi Juscelino, e o Collor é o Collor (...). Eu o apoio em meu nome, não no nome do meu pai" ${ }^{133}$. Restava ao ex-governador de Alagoas, portanto, continuar buscando sua identidade política em algum lugar entre Madri e Londres.

Collor tampouco poderia deixar de travar a batalha política no centro. Foi pego de surpresa, assim que voltou ao país, pela manobra em curso por parte de líderes moderados do PMDB e empresários expressivos do eixo Rio-São Paulo, que se dispunham a apoiar a candidatura de Covas como uma alternativa à dele para barrar uma possível eleição de um candidato de esquerda. Escreve Ricardo Noblat que, diante do risco de perder apoios que já tinha como certos, Collor foi ao encontro de Roberto Marinho, no Rio, e ameaçou renunciar à candidatura, sugerindo que "ele e os demais empresários que escolhessem outro candidato para derrotar Brizola e Lula" ${ }^{\prime 34}$. Em todo caso, o candidato do PRN deveria sofisticar seu discurso, buscando equiparar-se, em termos de consistência e profissionalismo, ao caminho que a candidatura do PSDB vinha trilhando. E Collor sabia que seu principal adversário ao centro, mesmo com o apoio de setores empresariais, teria alguma dificuldade em apresentarse como alternativa palatável ao grande público ${ }^{135}$.

\footnotetext{
132 OESP, "Collor se reúne com Juan Carlos”, 04 de julho de 1989, p. 4.

133 OESP, "Collor, em Diamantina, se diz herdeiro de Juscelino", 08 de julho de 1989, p. 5.

${ }^{134}$ Noblat, Ricardo. O Céu dos Favoritos: o Brasil de Sarney a Collor. Rio de Janeiro: Rio Fundo, 1990, p. 247.

135 “O senador Mário Covas, candidato dos 'tucanos' à Presidência, é um caso curioso de comunicação. Ele empolga os chamados formadores de opinião, mas, até aqui, não emociona a opinião pública, que o deixa mal
} 
É bem possível que essa comparação com Covas - que rendeu até mesmo uma brincadeira por parte de Delfim Netto, então deputado, que se referia a Collor como "o Covas de Alagoas" e ao candidato tucano como "o Collor de São Paulo"136 - tenha forçado do exgovernador alagoano a apresentar um programa consistente de governo, a respeito do qual havia se mantido estrategicamente em silêncio até então. E ele o fez no dia 12 de julho, exatamente uma semana após seu retorno ao país. Tratava-se não de um documento escrito, mas de um discurso de quase duas horas, proferido em ocasião da Convenção Nacional do PRN na qual se oficializou sua candidatura. Collor abriu sua fala declarando "guerra permanente aos piores males que infelicitam a nação: a inflação e a corrupção". Dividindo o discurso em vinte capítulos, passou - entre propostas mais concretas e generalidades - por praticamente todos os assuntos que os institutos de pesquisa identificavam como preocupações e anseios do eleitorado brasileiro ${ }^{137}$.

\subsection{A consolidação do programa de governo}

Os temas de política externa permearam o discurso que lançava a candidatura de Fernando Collor. Conforme argumentamos anteriormente, é possível identificar um forte componente sistêmico no teor das propostas, ou seja, elas mais representavam reações a pressões que nos eram colocadas vindas de fora (e devidamente assimiladas, de maneira habilidosa, pelo candidato do PRN) do que demandas societárias, derivadas da opinião pública ou de grupos de interesse particulares. Apesar disso, havia certo refinamento nas proposições que destoavam daquelas que marcaram a viagem à Europa. Parte da explicação deve-se ao fato de que, ao longo da viagem, Collor foi naturalmente amadurecendo suas posições, a partir das conversas com autoridades europeias.

Por outro lado, pode-se supor que, nos dias entre o retorno da viagem e o lançamento da candidatura, o candidato tenha sido assessorado, na formulação das propostas, por alguém do próprio Itamaraty. É o que sugere, por exemplo, matéria da Folha de São Paulo, de 18 de agosto de 1989, segundo a qual se cotava o então embaixador brasileiro no GATT, Rubens Ricupero, para ser chanceler de seu eventual governo. A ele, Collor dedicara "expressões

\footnotetext{
(...). O discurso de Covas na semana passada por um belo exemplar de ideias modernas, limpas, numa ofensiva contra as mamatas, subsídios, incentivos, pregando o que chamou de choque de capitalismo. Também defendeu a privatização e, ainda por cima, facilidades para o capital estrangeiro. É justamente desse tipo de proposta que o Brasil precisa. Mas o discurso só tem um problema: o próprio Covas". Dimenstein, Gilberto. "Covas versus Covas", FSP, 04 de julho de 1989, p. A-2.

${ }^{136}$ Dimenstein, Gilberto. "Delfim ironiza Covas", FSP, 05 de julho de 1989, p. A-2.

${ }^{137}$ FSP, "Collor apresenta suas propostas para governar", FSP, 13 de julho de 1989, p. A-8.
} 
generosas" ao longo da viagem a Europa. Quem o instruía em assuntos internacionais, até então, era sua assessora econômica, Zélia Cardoso de Mello, cujos conceitos "não chegaram a impressionar", trazendo "muito 'economês' e pouca intimidade com os conceitos das relações internacionais" $" 138$. Essa leitura foi confirmada em entrevista ao embaixador Ricupero, na qual afirma que, por intermédio de Marcos Coimbra, o candidato havia lhe solicitado um briefing sobre a política externa brasileira. O texto, entregue a Collor no contexto da viagem a Europa $^{139}$, foi publicado em compilação de artigos do embaixador Ricupero alguns anos mais tarde. Nele - que compararemos com as propostas enunciadas por Collor - lê-se o seguinte:

\begin{abstract}
“Qual poderia, então, ser uma plataforma para uma política externa moderna e atualizada?

A resposta é que esse tipo de política deveria estar dirigida a facilitar a inserção do Brasil num contexto internacional marcado por profundas mudanças econômicas e políticas, de maneira a permitir superar nossos estrangulamentos econômicos e retomar o desenvolvimento.

É claro que essa política não poderia ser feita no vácuo, isoladamente, sob pena de faltar-lhe toda credibilidade interna e externa. Ela teria de ser uma das pernas de um tripé, do qual as outras duas bases de sustentação seriam um vasto programa de reconstrução e reestruturação econômica e uma ação eficaz no âmbito da proteção ambiental, dos índios e dos direitos humanos"140
\end{abstract}

Todos esses elementos se faziam presentes no longo discurso de campanha ${ }^{141}$, cuja maior inovação estava ligada à dívida externa. $\mathrm{O}$ candidato propunha que a União retirasse seu aval dos débitos contraídos pela iniciativa privada e pelos governos e empresas estatais de âmbito estadual ou municipal junto aos credores internacionais. A medida subdividiria a dívida total - avaliada, naquele momento, em US\$ 110 bilhões - em fatias a serem renegociadas separadamente. Enquanto a proposta, em si, enquadrava-se sem dificuldades numa atitude nacionalista, interessada em maximizar a margem de manobra no árduo processo de renegociação da dívida - e aparentemente desinteressante aos credores - a postura do candidato o colocava, em termos retóricos, em campo bastante diverso das posições à esquerda. "Não quero, não pretendo nem desejo brigar com o FMI. Estou disposto,

\footnotetext{
${ }^{138}$ FSP, "Ricupero é favorito de Collor para chanceler", 18 de agosto de 1989, p. A-7.

${ }^{139}$ Embora, aparentemente, Collor e Ricupero não tenham se encontrado pessoalmente àquela ocasião.

${ }^{140}$ Ricupero, Rubens. "Um projeto de política externa para o Brasil”. In: Ricupero, Rubens. Visões do Brasil. Rio de Janeiro: Record, 1995, p. 189.

141 "Não é que eu pretenda que isso tenha influído, mas eu achei curioso porque, na pior das hipóteses, se ele não seu ou não se ligou, pelo menos mostra que era uma ideia que estava no ar, que eu tinha, que ele tinha, bem como outras pessoas (...). Você está, assim, num certo "comprimento de onda" (...), todo mundo sente mais ou menos a mesma coisa, apenas uns são mais capazes de exprimir isso mais claramente do que outros". Ricupero, Rubens. Entrevista ao autor, 30 de outubro de 2014.
} 
sim, a brigar dentro do FMI"142, disse Collor, para espanto de boa parte da plateia que o ouvia, especialmente de Zélia Cardoso de Mello, sua principal auxiliar econômica. No texto original do capítulo sobre a dívida, redigido por Zélia, não havia menção ao Fundo Monetário Internacional - entidade demonizada por amplos setores da sociedade e pelo próprio governo Sarney, que havia acabado de acusar os credores internacionais de colocarem o Brasil em "quarentena" financeira ${ }^{143}$. O trecho havia sido inserido por Collor, de próprio punho, momentos antes do discurso ${ }^{144}$.

Havia uma razão para tal. Se as viagens haviam lhe servido de lição, Collor sabia que, se eleito, não encontraria interlocutores dispostos a aceitar a proposta da retirada do aval sem que o Brasil se apresentasse como um país crível. A questão da credibilidade havia se tornado ponto crítico nos estertores do governo Sarney. "O Brasil de Sarney carrega uma fama mundial de trambiqueiro e incendiário de florestas", ironizava Paulo Francis ${ }^{145}$. Na semana que antecedeu o discurso de lançamento da candidatura, o Brasil deixara de honrar o pagamento de US\$ 800 milhões em juros ao Clube de Paris, e mais US\$ 30 milhões, além de decretar a centralização das operações de câmbio. Tudo indicava que o país rumava para uma situação de moratória, ainda que não declarada.

O que o governo Sarney talvez compreendesse, mas não apresentasse condições de contornar, é que mais do que simplesmente os rumos da economia, era a imagem do país que estava em jogo. México e Venezuela encontravam-se em meio a duras negociações das suas próprias dívidas, que envolviam um embate entre o Tesouro americano - disposto a aliviar parte dos devidos, no espírito do Plano Brady - e os bancos privados dos EUA, muito menos flexíveis ${ }^{146}$. Se estes países estavam logrando algum avanço no encaminhamento de seus próprios problemas junto ao governo Bush, isso se devia à credibilidade que haviam construído diante dos olhos americanos. E isso tinha muito menos a ver com estabilidade das instituições democráticas ou com a lisura do processo político, e mais com quão confiáveis eram os devedores em cumprir com as regras impostas por quem emprestava, nos marcos do Consenso de Washington.

Ao tratar do problema econômico em seu briefing entregue ao candidato, Ricupero aborda a questão da dívida da seguinte forma:

\footnotetext{
${ }^{142}$ Collor de Mello, Fernando. "Projeto Brasil Novo". In: Claret, Martin. O Fenômeno Collor. São Paulo: Martin Claret, 1989, p. 107.

${ }^{143}$ FSP, "Para Sarney, credores externos colocaram Brasil de "quarentena", 13 de julho de 1989, p. A-4.

${ }^{144}$ Veja, "Folgado em primeiro", 19 de julho de 1989, p. 34.

${ }^{145}$ Francis, Paulo. "George Bush intercede pelo México, mas não pelo Brasil”, 08 de julho de 1989, p. B-4.

146 “O presidente George Bush telefonou pessoalmente ao diretor-presidente do Citibank, John Reed, e pediu-lhe que fizesse um 'esforço extra' para ajudar o México, e Reed convocou, desde quarta-feira passada, uma reunião com os 15 diretores-presidentes dos principais bancos dos EUA”. Francis, op. cit.
} 


\begin{abstract}
"Um programa [de reestruturação econômica], do qual o plano anti-inflacionário, de saneamento de déficit e outras medidas, constituirá o ingrediente central, terá de ser vendido lá fora, aos governos dos principais países industrializados e às agências internacionais como o FMI e o Banco Mundial.
\end{abstract}

Nessa ação externa, estreitamente coordenada com a interna, se visará, em primeiro lugar, a obter uma redução substancial do serviço da dívida (...). É preciso trabalhar a partir daí, procurando primeiro qualificar o país como beneficiário potencial do Plano [Brady] mediante o ajuste interno da economia para, em seguida, ter legitimidade para exigir dos bancos um acordo satisfatório (...).

Para obter o acordo recente, o México, além da credibilidade conquistada pela redução do déficit e da inflação, precisou mobilizar a decidida e incessante pressão do Governo dos EUA sobre os bancos e sobre governos relutantes (...).

Para isso, a solução terá de ser buscada dentro do sistema e não contra ele, por negociação $e$ persuasão $e$ não por confronto, dadas as condições adversas da correlação de forças"147

Além da semelhança nas ideias defendidas por Collor e Ricupero em questões ligadas à dívida, havia também uma preocupação ambiental bastante cara a ambos. A conclusão do embaixador sobre a necessidade de uma "estratégia internacional integrada" passa, exatamente, por uma política efetiva de proteção ambiental e de defesa dos direitos humanos, aí incluídas as questões indígenas e os conflitos agrários.

\footnotetext{
"Esses temas, cada vez mais entrelaçados, vêm desencadeando contra o Brasil uma onda perigosa de hostilidade que penetra os mais diversos setores da opinião pública internacional e está na raiz de crescentes estrangulamentos para atrair não só empréstimos do Banco Mundial e do BID mas até de investimentos privados" ${ }^{\text {"148. }}$
}

Cumpre ressaltarmos que a questão ecológica já vinha se transformando há algum tempo na agenda brasileira. O país encontrava-se, nos idos de 1988, no epicentro da "segunda onda do meio ambiente" que informava o debate global sobre ecologia. Alguns acontecimentos tornaram o Brasil não somente exposto ao escrutínio internacional, como também vulnerável às pressões vindas das potências industrializadas, para as quais o tema da preservação ambiental havia ganhado novo significado. O primeiro deles relacionava-se à ampla divulgação do Relatório Brundtland ("Nosso Futuro Comum"), documento publicado em 1987 no âmbito das Nações Unidas e que refletia as preocupações ambientais de uma nova geração dos países desenvolvidos, principalmente europeus ${ }^{149}$. A poluição - tema presente nos debates ambientais desde a Conferência de Estocolmo, em 1972 - havia dado lugar,

\footnotetext{
${ }^{147}$ Ricupero, 1995, p. 190.

148 Idem, p. 192.

${ }^{149}$ United Nations. "Report of the World Commission on Environment and Development: our common future", 1987. Disponível em http://conspect.nl/pdf/Our_Common_Future-Brundtland_Report_1987.pdf
} 
dentre as preocupações da opinião pública, a temas como mudança do clima e perda de biodiversidade ${ }^{150}$.

Com efeito, o aumento das queimadas na Amazônia recebeu particular destaque na mídia internacional, uma vez que se relacionava com os novos temores dos ambientalistas. Alguns artigos na imprensa internacional contribuíam para o cenário aparentemente catastrófico, como aquele publicado no The New York Times, em agosto de 1988: “A destruição e a queima de florestas aqui [no Brasil] é tão vasta, dizem os cientistas, que ela pode ser responsável por pelo menos um décimo da emissão antrópica de dióxido de carbono, que se acredita estar causando um aquecimento da terra por meio do efeito estufa" ${ }^{\text {"151 }}$. Outros chegavam imputar responsabilidade sobre o governo brasileiro. A despeito de todos os problemas internos - das negociações da Assembleia Constituinte à crise econômica pósCruzado - o presidente José Sarney decide tomar medidas que fossem capazes de apaziguar, interna e externamente, a animosidade da opinião pública, sinalizando o compromisso do país com a questão ecológica ${ }^{152}$.

A resposta brasileira também se manifestou no campo diplomático. O Itamaraty vinha acompanhando, ao longo do ano de 1988, o crescimento das críticas de grupos ambientalistas e da imprensa internacional quanto aos problemas ambientais brasileiros. Aliados às dificuldades financeiras e à desaceleração da economia, tais problemas "constituíam importantes barreiras para que aspectos mais positivos da sociedade brasileira, como a redemocratização e o processo de elaboração da nova Constituição, pudessem ser percebidos no exterior" ${ }^{\prime 153}$. Foi, portanto, do Ministério das Relações Exteriores que partiu a ideia de sediar a Conferência de 1992 no Brasil, manifestada pelo então embaixador junto às Nações

\footnotetext{
${ }^{150}$ Corrêa do Lago, 2006, p. 147.

${ }^{151}$ NYT, "Vast Amazon Fires, Man Made, linked to Global Warming", 12 de Agosto de 1988. Disponível em http://www.nytimes.com/1988/08/12/world/vast-amazon-fires-man-made-linked-to-global-warming.html

152 "O Presidente lançou, em outubro de 1988, no mesmo mês em que foi adotada a nova Constituição, o Programa Nossa Natureza, que envolvia sete Ministérios e que tinha como objetivos: a) conter a ação predatória do meio ambiente e dos recursos naturais renováveis; b) fortalecer o sistema de proteção ambiental na região amazônica; c) desenvolver o processo de educação ambiental e de conscientização pública para a conservação do ambiente; d) disciplinar a ocupação e exploração racional da Amazônia Legal, fundamentadas no ordenamento territorial; e) regenerar o complexo de ecossistemas afetados pela ação antrópica; e f) proteger as comunidades indígenas e as populações envolvidas nos processos extrativistas. O Governo anunciou, também, a suspensão dos incentivos fiscais a projetos agropecuários nas áreas de floresta tropical densa (...). Poucos meses depois, para complementar as medidas anunciadas pelo Governo, foi decidida a criação do Instituto Brasileiro de Meio Ambiente e dos Recursos Naturais Renováveis (IBAMA), que assumiria as funções de quatro órgãos a serem extintos: o Instituto Brasileiro de Desenvolvimento Florestal (IBDF), a Secretaria Especial do Meio Ambiente (SEMA), a Superintendência de Desenvolvimento da Pesca e a Superintendência do Desenvolvimento da Heveicultura. Para presidir o IBAMA, é nomeado o então porta-voz da Presidência, Fernando César de Mesquita, que tinha acesso direto ao Presidente Sarney, em mais uma indicação da prioridade do tema ambiental para o Governo". Corrêa do Lago, 2006, p. 150. Deve-se mencionar também o artigo sobre meio ambiente da CF-88 (Capítulo VI, Art. 255, "Do Meio Ambiente"), redigido pelo deputado Fábio Feldmann (PSDB-SP).

${ }^{153}$ Corrêa do Lago, 2006, p. 151.
} 
Unidas, Paulo Nogueira Batista, em discurso na Segunda Comissão da Assembleia Geral, em 6 de dezembro de 1988. Do ponto de vista político, sobretudo em relação à credibilidade internacional do Brasil, o governo tinha consciência de que tinha mais a ganhar do que a perder ao tomar essa decisão - cujo risco mais evidente era ampliar a exposição brasileira às preocupações ecológicas $^{154}$.

Mas era claro para os diplomatas que articularam a candidatura brasileira em 1988 entre os quais Nogueira Batista e o Secretário-Geral do Itamaraty, Paulo Tarso Flecha de Lima - que o Brasil não queria assumir, com a decisão de sediar a Conferência, uma posição de alinhamento às prioridades dos países desenvolvidos. Continuava, portanto, a defender os corolários diplomáticos do desenvolvimento econômico e da soberania inalienável sobre seus recursos naturais. O que não se esperava era que, com o assassinato de Chico Mendes seringueiro e ambientalista de prestígio internacional - duas semanas após a decisão brasileira de realizar a Conferência, o tom das críticas ambientais internacionais aumentaria. Trazia-se à tona o entendimento (que já ganhava espaço em alguns círculos no hemisfério Norte) de que a floresta amazônica, por se tratar de um bem público global, deveria ser transferida para controle internacional. Era o conceito do direito de ingerência, outrora aplicado a questões humanitárias, agora sendo estendido a "massacres ambientais"155.

A pressão internacional manifestava-se de diversas maneiras: de protestos de ambientalistas destinados ao governo brasileiro a declarações de lideranças mundiais, a credibilidade brasileira estava sendo colocada em xeque. Em janeiro de 1989, uma delegação de vinte norte-americanos - dentre os quais os senadores Timothy Wirth, Albert Gore e John Heinz, os deputados John Bryant e Gerry Silkorski e o biólogo Thomas Lovejoy, do Smithsonian Institute - veio ao Brasil, reunindo-se com o presidente Sarney e com autoridades e ativistas locais na região amazônica. Ao fim da viagem, Wirth declarou que o governo brasileiro subestima a questão ambiental, que o problema ecológico no país é "extremamente complicado" e que o salvamento da Amazônia é "absolutamente crucial"156. Al Gore - que mais tarde transformou-se num defensor vocal da causa ecológica - chegou a ponto de declarar que "ao contrário do que creem os brasileiros, a Amazônia não é sua propriedade, ela pertence a todos nós"157.

\footnotetext{
154 Idem

${ }^{155}$ Idem, p. 153. A doutrina, criada pelo jurista Bernard Kouchner em 1987, desafiava abertamente o conceito de soberania no alvorecer de uma era não mais marcada pela bipolaridade, ao impor o "droit d'ingerence" ou “devoir d'assistance à peuple en danger" (dever de assistência a povo em perigo) em situações de crise humanitária, mesmo sem a devida autorização de intervenção por parte do governo-alvo.

${ }^{156}$ FSP, "Brasil subestima meio ambiente, diz Wirth", 20 de janeiro de 1989, p. C-4.

${ }^{157}$ NYT, "Whose Rain Forest is This, Anyway?", 18 de maio de 2008.
} 
Dois meses mais tarde, na Conferência Internacional sobre Proteção da Atmosfera do Globo, na Haia, os representantes brasileiros, Flecha de Lima e Bernardo Pericás, ouviram diretamente do primeiro-ministro da França, Michel Rocard, que o Brasil não era capaz de cuidar da Amazônia ${ }^{158}$. O presidente francês, François Mitterrand - um dos proponentes da Conferência, junto com os chefes de Estado de Holanda e Noruega - foi mais longe, acrescentando que achava natural que alguns países de Terceiro Mundo renunciassem "a parte de suas soberanias" em questões ambientais. O Itamaraty trabalhou para evitar, na reunião multilateral, que se criasse - como era a vontade dos proponentes - uma "polícia ecológica internacional", ou um "ministério público ecológico"159.

As crescentes pressões internacionais nas questões ambientais, que compreendemos como um atributo das dinâmicas próprias de um sistema internacional em transformação, inspiraram um capítulo inteiro da proposta de governo lançada por Collor. Intitulada " $\mathrm{O}$ Desenvolvimento Não-Predatório", o trecho faz referências gerais à situação do debate ambiental, tece críticas à incapacidade do governo Sarney em proteger os ecossistemas locais, e propõe soluções multilaterais para a crise ecológica - como o Imposto Internacional sobre Poluição, já apresentado em sua viagem à Europa. Mais importante, contudo, é a afirmação de que "o controle ambiental, a manutenção dos ecossistemas e o problema de poluição têm que ser tratados soberanamente pelas nações". Prossegue o candidato do PRN, a título conclusivo, que "o planejamento de um desenvolvimento não-predatório faz parte, consequentemente, de nossas responsabilidades para com o resto da humanidade e, fundamentalmente, para com o nosso próprio futuro como nação soberana"160.

\subsection{Questões internacionais e a reta final da campanha}

Desde a apresentação do programa de governo e a definição da corrida eleitoral, os temas internacionais passaram a ocupar lugar menor nas campanhas, inclusive na de Fernando Collor. Agosto, no entanto, começou com uma declaração polêmica que o perseguiu pelo restante do mês - sem grandes implicações eleitorais, mas com o potencial de criar um malestar de maiores proporções. No dia 2, durante debate no clube "A Hebraica”, em São Paulo, Collor emitiu uma série de opiniões "nitidamente pró-semitas", em seus próprios termos. Disse ser contra a criação de um Estado palestino nos territórios árabes ocupados por Israel e

\footnotetext{
${ }^{158}$ Corrêa do Lago, 2006, p. 153.

${ }^{159}$ FSP, "Por ambiente, países devem abrir mão da soberania, diz Mitterrand", 12 de março de 1990, p. C-3.

${ }^{160}$ Collor de Mello, 1989, p. 124-5.
} 
discordou da devolução de Gaza e da Cisjordânia para esses fins. "Israel vem lutando muito, por tantos anos. Que não mexam com os territórios que já foram ganhos”. Aplaudido com entusiasmo pelas quase mil pessoas que lotavam o auditório do clube, o candidato também deu pistas de como seria sua política externa com relação ao conflito israelo-palestino. Em primeiro lugar, manifestou-se contrário ao voto dado pelo Brasil nas Nações Unidas, em 1975, equiparando o sionismo ao racismo. Disse, ademais, não concordar com o estabelecimento, no Brasil, de um escritório de representação da Organização para a Libertação da Palestina (OLP) - que qualificou como uma entidade "terrorista". Se eleito, não receberia seu líder, Yasser Arafat, com honras de chefe de Estado ${ }^{161}$.

Se suas posições certamente soaram bem aos ouvidos da comunidade judaica, elas causaram espanto não somente entre os árabes, mas entre os apoiadores da causa palestina em geral. Nos dias que se seguiram imediatamente às declarações, a Federação das Entidades Árabe-Palestinas Brasileiras e a Federação das Associações Muçulmanas do Brasil enviaram telegramas de protesto ao comitê de Collor. Algumas lideranças tentaram contemporizar, como o representante da Liga Árabe no Brasil, Mohamed Adnan Baghdady, ao afirmar que o candidato "fez esta declaração num momento inadequado". Outros, como Tawfiq Awad, da Confederação Palestina Latino-Americana, foram mais longe ao dizer que Collor "revelou sua face racista". O Itamaraty também recebeu uma série de queixas de diplomatas árabes, temerosos de que, com a eleição de Collor, a posição histórica do governo brasileiro - que reconhecia a OLP como "única e legítima representante do povo palestino" - fosse colocada em risco. Na Câmara Municipal de São Paulo, cidade de grande população descendente de árabes, uma frente suprapartidária - composta pelos líderes de PT, PDS, PCB, PCdoB e PDT - assinou manifesto em repúdio às declarações de Collor ${ }^{162}$. Em Foz do Iguaçu, o presidente do Centro Cultural Árabe-Brasileiro, Mohamed Barakat, organizou um protesto de cerca de 400 pessoas e bloqueou parte da estrada que dá acesso à cidade quando o candidato foi visitá$1 a^{163}$.

As manifestações obrigaram Collor a retroceder. Na semana seguinte, o candidato publicou uma nota oficial em que pregava o entendimento entre árabes e judeus, de uma perspectiva de equidistância. Recebeu elogios, embora com certo tom de condescendência ("este é o problema de quem tenta agradar a todos, acaba ganhando a desconfiança dos dois lados"), por parte de Gilberto Dimenstein, que escreveu em sua coluna:

\footnotetext{
${ }^{161}$ FSP, "Candidato se diz "pró-semita", 04 de agosto de 1989, p. A-5.

${ }^{162}$ FSP, "Entidades árabes protestam", 05 de agosto de 1989, p. A-6.

${ }^{163}$ FSP, "Sionismo - 3", 27 de janeiro de 1990, p. A-7.
} 


\begin{abstract}
"A nota mostra que, se Collor ainda está imaturo politicamente, incapaz de medir o efeito de suas palavras, vem aprendendo alguma coisa. Tanto que melhorou os termos de sua posição em relação ao conflito do Oriente Médio, certamente acalmando o ambiente que iniciava uma radicalização (...). A eterna crise no Oriente Médio serve como exemplo de que o destempero não compensa" ${ }^{\text {"164 }}$.
\end{abstract}

No dia 15 de agosto, o candidato do PRN almoçou na casa do embaixador da Arábia Saudita como forma de dirimir o mal-estar das declarações realizadas no começo do mês. No evento, doze embaixadores e o novo representante da OLP no Brasil, Ahmad Sobeh, ouviram uma promessa de Collor de Mello: caso eleito presidente, trabalharia para estreitar as relações diplomáticas e ampliar o comércio e os investimentos com o mundo árabe. $\mathrm{O}$ candidato também falou em favor da paz no Oriente Médio e em favor da autodeterminação dos povos. Ao final, tanto Collor quanto o embaixador saudita, Abdullah Saleh Hababi, declararam que as divergências estavam resolvidas ${ }^{165}$.

A querela, contudo, durou por mais alguns dias. Em primeiro lugar, nem alguns membros da comunidade judaica nem dos árabes aceitaram, pelo valor de face, as declarações mais recentes do candidato. O presidente da Confederação Israelita do Brasil e do Congresso Judaico Latino-Americano, Benno Milnitzky, afirmou que Collor "se precipitou por duas vezes", lamentando sua inconstância de posições e alegando que ela poderia acirrar ainda mais o estado de ânimo entre as duas comunidades. Hussein Mohamed El Zoghbi, presidente da Federação das Associações Muçulmanas do Brasil, qualificou as declarações do exgovernador de Alagoas "um atentado à inteligência" e completou: "nós resistiremos a essa candidatura durante toda a campanha". As reações mais exaltadas vieram de Abdo Nassif, presidente do Centro Cultural Árabe-Brasileiro, para quem a reunião de Collor com os embaixadores não fará com que a comunidade esqueça suas graves declarações. "Nem o presidente mais conservador dos EUA faria tais declarações. Eu gostaria de saber quanto custou o seu discurso na Hebraica, porque só pode ter sido pago" ${ }^{\text {"166. }}$.

Além disso, os demais candidatos buscaram capitalizar as polêmicas declarações de Collor. Maluf e Brizola rapidamente demarcaram suas posições, surpreendentemente semelhantes, de apoio à criação de um Estado palestino, com a permanência e a segurança de Israel, bem como a manutenção do escritório da OLP no Brasil. Em entrevista a jornalistas estrangeiros, na Confederação Nacional do Comércio, no Rio, Paulo Maluf disse que a criação da Palestina é uma forma de acabar com a crise do Oriente Médio. No debate da TV

\footnotetext{
${ }^{164}$ Dimenstein, Gilberto. “A OLP e as eleições”, FSP, 15 de agosto de 1989, p. A-2.

165 OESP, “Collor almoça com árabes e faz as pazes”, 16 de agosto de 1989, p. 7.

${ }^{166}$ FSP, "Candidato deixa judeus e árabes insatisfeitos", 18 de agosto de 1989, p. B-5.
} 
Bandeirantes, o candidato do PDT disse ser "contra qualquer tipo de repressão" ${ }^{\text {"167 }}$. Dias mais tarde, em almoço semelhante àquele do qual havia participado Collor, na residência oficial do embaixador saudita, disse que trabalharia, se eleito, pelo reconhecimento soberano da Organização para a Libertação da Palestina ${ }^{168}$. O próprio Jânio Quadros, que quase foi candidato, disse que seu apoio ao alagoano estaria condicionada a ele "não cometer mais besteiras", como suas posições hesitantes sobre o conflito israelo-palestino ${ }^{169}$.

Com a poeira mais baixa, na segunda metade de agosto, Collor cogitou fazer outra viagem ao exterior, dessa vez ao México e aos Estados Unidos. Internacionalmente, o momento era auspicioso. No início daquele mês, em participação no $7^{\circ}$ Encontro da Comissão Binacional Estados Unidos-México, secretário Baker anunciou: “os Estados Unidos não têm amigo mais importante do que o México"170. A declaração, claramente destinada a selar o início de uma nova era nas relações entre os dois países, era entendida como reflexo da mudança de comportamento do governo mexicano, sob o comando de Salinas de Gortari, com relação ao seu vizinho do norte. O México, que já vinha ganhando tratamento diferenciado na condução do problema da dívida, agora era elevado à condição de parceiro preferencial. A Collor interessava conhecer os detalhes do acordo firmado pelos mexicanos com os bancos credores - ainda que houvesse certo ceticismo, por parte dos principais assessores econômicos do candidato, quanto às vantagens do acordo ${ }^{171}$.

Para Collor, atrelar sua imagem à do presidente que havia causado uma reviravolta positiva nas relações com os EUA e na situação da dívida poderia ser uma boa alternativa ao duelo de campanha que se acirrava. No roteiro, também estava incluído um jantar na residência oficial do embaixador em Washington, Marcílio Marques Moreira, para o dia 7 de setembro, além de encontros com o presidente da Câmara dos EUA, Tom Fowley, com empresários do Council of America e com os secretários de Estado, James Baker, e do Tesouro, Nicholas Brady ${ }^{172}$. Se conseguisse uma reunião com Bush, aliás, Collor seria um dos raros casos em que um candidato era recebido, antes das eleições, pelo presidente norteamericano - exceção que havia sido aberta, recentemente, pelo próprio Salinas de Gortari ${ }^{173}$.

Os dias se passaram e não se falou mais da turnê de Collor de Mello pela América do Norte, por mais avançadas que estivessem as tratativas para os encontros de alto nível. O

\footnotetext{
${ }^{167}$ OESP, “Candidatos querem árabes e judeus”, 16 de agosto de 1989, p. 7.

${ }^{168}$ FSP, "Pedetista defende soberania dos palestinos", 24 de agosto de 1989, p. B-3.

${ }^{169}$ FSP, "Jânio Quadros estuda apoio à candidatura Collor", 17 de agosto de 1989, p. B-4.

${ }^{170}$ Veja, "Caso de boa vizinhança", 16 de agosto de 1989, p. 55.

${ }^{171}$ O Globo, "Candidato vai se avistar com Presidente do México”, 15 de agosto de 1989, p. 3.

172 O Globo, "Candidato...", p. 3.

${ }^{173}$ FSP, “Candidato visitará o México", 18 de agosto de 1989, p. B-5.
} 
cancelamento da viagem convida a pelo menos três explicações. Em primeiro lugar, pode ser que não se tenha conseguido a audiência com Bush, o que reduziria drasticamente os benefícios relativos dos dez dias de ausência - os demais encontros, por relevantes que fossem, não causariam o mesmo impacto eleitoral. É também possível que a desistência estivesse ligada à tendência de estagnação em que o candidato se encontrava nas pesquisas. A sondagem do Datafolha realizada entre 19 e 20 de agosto, bem como a do Ibope, do dia 25 de agosto, mostrava que Collor atingira o teto das intenções de voto - estacionando em 41\%, no primeiro caso, e em 44\%, no segundo, o que o mantinha distante dos demais candidatos, mas não garantia a vitória no primeiro turno ${ }^{174}$. Por fim, pode-se conjecturar que o candidato do PRN decidiu cancelar sua ida ao exterior em função de outro candidato que, à semelhança do que fizera Brizola em junho, tomou a dianteira e embarcou primeiro rumo aos Estados Unidos: Paulo Maluf.

Maluf havia resolvido viajar "furtivamente" aos EUA no dia 3 de setembro - data originalmente aventada para o início da excursão de Collor - ao fim de uma semana de conquistas eleitorais importantes. Depois de muito esforço, o pedessista conseguira polarizar o debate com Brizola, ameaçando-lhe a segunda colocação e criando embaraços ao exgovernador do Rio ${ }^{175}$. Causou certa estranheza, portanto, a decisão do candidato do PDS de desaparecer por cinco dias em vez de prosseguir ocupando os espaços abertos por Brizola. Percebendo, por outro lado, que dificilmente tiraria votos de seu principal oponente, Maluf decidiu atuar numa seara na qual Collor havia se saído bem: as viagens internacionais, vinculando seu nome ao de um estadista estrangeiro. O escolhido era Ronald Reagan, considerado o "político do século" dos EUA e de quem Maluf, segundo ele próprio, era amigo pessoal $^{176}$.

O plano, contudo, não saiu como o esperado, e Reagan não permitiu que fossem veiculadas imagens do encontro. Não bastasse isso, ao chegar em Nova York, o candidato do PDS foi vaiado por brasileiros residentes na cidade, ao participar de uma missa em comemoração ao dia da independência do Brasil. Diante do fiasco da viagem, Maluf tentou se esquivar de várias maneiras. Disse, por exemplo, que não tinha interesse de usar fotos de

\footnotetext{
${ }^{174}$ Veja, "Últimos números", 18 de outubro de 1989, p. 46-47.

175 "Embora Brizola tenha passado uma descompostura em Maluf - por este ter dito que o Brizola não seria seu ministro porque ele não teria ministério do jogo do bicho - o candidato pedessista conseguiu o que queria. $\mathrm{Ou}$ seja, ser notado por Brizola. 'Ele demonstrou que eu estou incomodando', disse Maluf depois do incidente. No dia seguinte a este tento malufista, Brizola colaborou mais uma vez com o concorrente. Agrediu verbalmente uma repórter de televisão, referindo-se a uma peça íntima do vestuário da moça. A deselegância foi rapidamente apontada por Maluf como 'desequilíbrio de quem não está preparado para ser presidente"'. FSP, "Viagem aos EUA prejudica campanha de Maluf", 10 de setembro de 1989, p. B-3.

${ }^{176}$ FSP, "Viagem aos EUA...", p. B-3.
} 
dirigentes estrangeiros na campanha e que seus objetivos na viagem eram muito maiores do que uma foto com o ex-presidente norte-americano. "Posso garantir que não é turismo que estou fazendo por aqui", afirmou Maluf a jornalistas, ainda em sua primeira parada, Los Angeles ${ }^{177}$. Quanto às vaias, o candidato acusou ter sido um caso isolado, tendo partido de uma única mulher, que "sofre das faculdades mentais". O episódio, segundo ele, serviria para comprovar a "péssima" imagem do país no exterior ${ }^{178}$. A experiência de Maluf, avaliada pelo próprio comitê de campanha como um fracasso, era símbolo claro dos perigos de tentar-se atrelar a candidatura a alguma figura no exterior. Na medida em que a batalha eleitoral se acirrava, os custos de uma viagem internacional aumentavam dramaticamente.

Leonel Brizola foi o último a tentar capitalizar uma ida ao exterior antes do início da campanha na televisão, aproveitando um momento em que o pedetista estava em ascensão e sofrendo ataques de Collor, candidato em queda relativa nas intenções de voto ${ }^{179}$. A estratégia, semelhante àquela que ele próprio e seu adversário haviam utilizado alguns meses antes, era a de se vincular a figuras importantes do cenário político europeu como forma de, a um só tempo, assegurar uma aura de credibilidade à candidatura e distinguir-se dos adversários à esquerda - já que Lula não tinha a mesma entrada nos círculos socialistas europeus - e à direita - já que Collor havia tentado se aproximar de alguns líderes da socialdemocracia do velho continente, mas sem sucesso. Na véspera do embarque para a Europa, Brizola participou do programa Palanque Eletrônico, na Globo, e deu a seguinte declaração:

\begin{abstract}
"Os partidos socialistas, sociais democratas e trabalhistas na Europa, aos quais somos ligados - (...) [têm] os governos mais avançados, as propostas mais modernas de governo. O Brizola caudilho, o Brizola que é tão desprezado pelas elites aqui foi acolhido lá. Imaginem que se me honraram escolhendo meu nome para VicePresidente da Internacional Socialista, alguma coisa viram no Leonel Brizola (...). Os nossos vínculos no mundo são com aquela constelação de nações e com aqueles estadistas: Mitterrand, Mário Soares, Felipe González, Craxi e com aquele homem extraordinário, cheio de carisma, que até hoje a sua corrente não encontrou outro que o substituísse, que é o Willy Brandt. Enfim, nós nos colocamos aí, ${ }^{\prime 180}$.
\end{abstract}

Em solo europeu, Brizola e sua esposa, Neuza Goulart, foram recebidos pelo papa João Paulo II no Vaticano. Apesar de não ser católico praticante, o candidato do PDT prometeu comportar-se como o Sumo Pontífice, se eleito presidente, dedicando um dia da

\footnotetext{
${ }^{177}$ OESP, “O segredo de um 'encontro"”, 05 de setembro de 1989, p. 4.

${ }^{178}$ FSP, "Maluf tenta amenizar fiasco da viagem aos EUA", 10 de setembro de 1989, p. B-3.

${ }^{179}$ No dia 10 de setembro, Collor de Mello admitiu, pela primeira vez, a possibilidade de participar de debates antes do primeiro turno das eleições. Em meio a um périplo pelo país, em que realizou gravações para o horário eleitoral gratuito, via sua candidatura cair em junto aos eleitores mais ricos e educados. Ver FSP, "Collor admite debate antes do primeiro turno", 11 de setembro de 1989, p. B-1.

${ }^{180}$ O Globo, "O Leonel Brizola caudilho foi acolhido na Europa", 10 de setembro de 1989, p. 16.
} 
semana a atender pessoalmente à população, a "todos aqueles que se sentirem desprezados pelos poderosos". A decisão de visitar a Santa Sé foi criticada pelos adversários que disputavam o segundo lugar nas pesquisas com Brizola: em entrevista com os candidatos à sucessão, Lula e Covas, que participaram juntos do programa de rádio, condenaram a atitude do pedetista. Para o tucano, "Igreja não deve ter candidato nem partido". O petista preferiu a ironia: "Brizola deve ter muitos pecados"181. Questionado por jornalistas se a audiência com o Papa tinha alguma ligação com o processo eleitoral no Brasil, Brizola disfarçou: "Não tem ligação direta, mas é natural que se divulgue o comportamento pessoal de Leonel Brizola de reverência, de respeito, de apreço pelos sentimentos religiosos de nosso povo" ${ }^{\text {182 }}$. Ao falar sobre o momento político atual, aproveitou para criticar Collor: "há certas candidaturas que se apresentam como uma bandeira de mudança e não passam de uma farsa, simples continuidade de tudo que levou o país ao atoleiro" ${ }^{183}$. Além do papa, o candidato do PDT encontrou-se com o primeiro-ministro italiano, Bettino Craxi, e com seu contraparte espanhol, Felipe González.

A estratégia de Brizola teve impacto eleitoral pífio. O Datafolha dos dias 23 e 24 de setembro indicava $33 \%$ para Collor (contra $41 \%$ do mês anterior), 15\% para Brizola (contra 14\%) e 7\% para Lula (contra 5\%). Da mesma forma, o Ibope de 22 de setembro apontava $39 \%$ para Collor (contra $44 \%$ da pesquisa do dia 8 de setembro), 14\% para Brizola (contra os mesmos $14 \%$ ) e $7 \%$ para Lula (contra $6 \%)^{184}$. A tendência de queda de Collor relacionava-se pouco com Brizola, que seguia estagnado ${ }^{185}$.

Nos meses seguintes, até a data do primeiro turno das eleições - 15 de novembro - os temas internacionais não voltaram a balizar as campanhas. Àquela altura, as identidades políticas dos candidatos já estavam relativamente consolidadas e não houve nenhum evento político de nível global que canalizasse as atenções políticas no Brasil. O único episódio que merece destaque no contexto da campanha ocorreu em fins de outubro, quando os embaixadores dos sete países mais industrializados do mundo, reunidos no Grupo dos Sete (G-7), promoveram encontros com cada um dos candidatos à presidência, com o objetivo de clarificar suas posições quanto a temas internacionais, em particular o tratamento à dívida

\footnotetext{
${ }^{181}$ OESP, "Lula e Covas atacam Brizola pelo rádio", 13 de setembro de 1989, p. 4.

182 OESP, "Em Roma, Brizola promete imitar o papa", 14 de setembro de 1989, p. 5.

${ }^{183}$ FSP, "Brizola vê o papa e faz ataque indireto contra Collor", 14 de setembro de 1989, p. B-3.

${ }^{184}$ Veja, "Últimos números", 18 de outubro de 1989, p. 57-8.

${ }^{185}$ De acordo com Newton Rodrigues, comentando as pesquisas que haviam saído naquela semana: "Há várias explicações para [a queda de Collor], e a mais importante talvez se encontre nos erros verificados na campanha (...). Em contrapartida, não surgiu outro pólo de aglutinação. O foguetório sobre Guilherme Afif está mais inspirado nos desejos de integrantes de camadas de renda mais alta que em dados reais (...). $\mathrm{O}$ fato mais destacável, depois de nova descida de Collor, é, em termos ibopeanos, a reversão de Lula, que voltou a subir. Sua presença deve estar contribuindo para o estacionamento de Brizola". Rodrigues, Newton. "Pesquisas e abusos", Folha de São Paulo, 29 de setembro de 1989, p. A-2.
} 
externa e ao capital estrangeiro. Preocupava aos embaixadores, em particular, a radicalização dos discursos dos políticos que disputavam a presidência.

Dos sete principais candidatos, o único com quem os representantes do G-7 não conseguiram conversar foi Collor - que havia, recentemente, despertado a indignação dos países industrializados ao chamar os credores de "safados". Segundo um assessor do candidato do PRN, "o Fernando não tem tempo disponível em sua agenda. Estamos na reta final da campanha. Nossa preocupação agora é interna"186. A estratégia deu certo, e Collor sagrou-se o candidato mais votado no primeiro turno das eleições de 1989 , com quase $29 \%$ dos votos válidos.

\subsection{O segundo turno das eleições e a construção do discurso de modernização competitiva}

No mês transcorrido entre os dois turnos eleitorais, os candidatos não se debruçaram especificamente sobre temas internacionais, embora a campanha de Collor e Lula tenha ocorrido no contexto das repercussões da queda do muro de Berlim, iniciada na noite de 9 de novembro. Com ela, a dicotomia ideológica que pautara as décadas de Guerra Fria, bem como a retórica socialista, baliza de diversas campanhas que participaram da corrida presidencial, começavam a causar uma estranheza que seria impensável alguns meses antes. Ao passo que se dissolviam as fronteiras da cortina de ferro soviética, os projetos oferecidos pelo candidato Luiz Inácio Lula da Silva, do Partido dos Trabalhadores (PT), outrora progressistas, revestiam-se de incômodo anacronismo.

Isso serviu à campanha de Collor, que se esforçou em traçar uma linha muito clara entre o moderno, representado por ele, e o arcaísmo da frente de esquerda. A pouco mais de uma semana do pleito decisivo, o programa do candidato Fernando Collor de Mello anunciava, com uma voz em off, uma das virtudes que haviam permeado a imagem e o discurso daquela campanha nos intensos meses que precederam ao pleito: a modernidade. "Para fazer o programa mais moderno dos candidatos, Collor viajou muito, pelo Brasil e pelo exterior; único estadista que pode por o Brasil ao lado das nações mais desenvolvidas do mundo". Às vésperas da eleição, no último debate entre os contendores - que deixou sua marca na história pela edição tendenciosa ao candidato da direita, que o impulsionou na reta final -, Collor demarcava, apropriando-se do espírito do tempo, as diferenças profundas entre ele próprio e Lula:

\footnotetext{
${ }^{186}$ O Globo, "Embaixadores das grandes nações checam radicalismo de candidatos", 20 de outubro de 1989, p. 2. Grifo nosso.
} 
"De um lado está a candidatura do centro democrático, por mim representada, do outro lado está uma candidatura que esposa teses estranhas ao nosso meio, teses marxistas, teses estatizantes, teses que não primam pelos princípios democráticos consagrados na nova carta constitucional"187

Aos 17 de dezembro de 1989, Fernando Collor de Mello sagrava-se vitorioso nas urnas, com mais de 35 milhões de votos. O primeiro presidente eleito pela via direta após três décadas de turbulências e exceções políticas havia chegado ao cargo máximo da República com a promessa de levá-la rumo à modernidade, colocando o Brasil no rol das nações desenvolvidas. Restava-lhe saber por onde começar.

Sabia-se, por um lado, que o desenvolvimento do país em direção à modernização envolvia um imbricado jogo entre pactos domésticos, decisões econômicas e barganhas internacionais. O modelo que havia pautado as relações entre Estado e sociedade ao longo das décadas anteriores, o chamado nacional-desenvolvimentismo, chegava a um trágico fim ${ }^{188}$. Legou ao país, em função de seu esgotamento, um processo de endividamento externo que se transformara, no decurso da década anterior, em um ciclo hiperinflacionário. As circunstâncias globais eram, igualmente, pouco auspiciosas: diante do fim do confronto bipolar, os Estados Unidos emergiam, solitários, como a única potência mundial. Sem o esteio da estabilidade assegurada pelo equilíbrio de poder entre americanos e soviéticos, e diante do colapso das economias do Terceiro Mundo, o Brasil perdia capacidade de manobrar entre os conflitos cardeais como fizera nas duas décadas anteriores. Vinha, além disso, de longos anos de confrontações e desencontros no campo econômico com os EUA, de quem o país era um dos grandes devedores.

Por outro lado, tinha-se consciência de que a solução prometida por Collor não conseguiria atacar, simultaneamente, todos os gargalos de uma sociedade polarizada e de uma economia em frangalhos. As alternativas de choque, tão propaladas pelo candidato em plena campanha - como na famigerada metáfora da bala de prata para matar o "tigre da inflação" seriam, no máximo, medidas para estancar a corrosão econômica, provocada pela escalada inflacionária e pela dívida externa, para que ajustes mais profundos fossem realizados posteriormente. Se o agora presidente eleito - "um político que vive com a ideia fixa de obter resultados, obtê-los logo e obtê-los de maneira visível para o público em geral" ${ }^{189}$ necessitava empreender melhorias tangíveis para o país que o elegera, seria necessária uma

\footnotetext{
${ }^{187} \mathrm{http} / / / \mathrm{www} 1$. folha.uol.com.br/fsp/ilustrad/fq1112199907.htm

188 Sallum Jr., Brasilio. Labirintos: dos generais à Nova República. São Paulo: Hucitec, 1995.

189 Veja, "Collor chega à praia", 24 de dezembro de 1989, p. 14.
} 
boa dose de tempo. Um paradoxo, claro, tanto para alguém que havia se demonstrado tão imediatista em suas aspirações, tanto para o povo que, do alto de seus desencantos com os rumos da Nova República, não tardava em decretar o fracasso do governo em que depositara todas suas esperanças.

Conduzir o Brasil ao Primeiro Mundo era uma ambição muito maior do que debelar a inflação. Envolvia, a um só tempo, recompor a economia do país e adequá-la a um mundo em transformação, marcado pelo aprofundamento da interdependência financeiro-comercial e pelo rearranjo das forças políticas e econômicas. As velhas soluções protecionistas que legaram ao país sucessivos anos de crescimento não mais se aplicavam ao chamado "mundo globalizado", passando a ser compreendidas como antitéticas à prosperidade das sociedades abertas, guiadas pela democracia liberal e pela economia de mercado. Nos centros intelectuais das nações desenvolvidas, os diagnósticos sobre as relações internacionais da virada da década de 1990 apresentavam variações destes temas, abarcando desde perspectivas otimistas quanto ao "fím da História" e ao triunfo dos regimes democráticos ${ }^{190}$ até leituras, de forte tom revisionista, que preconizavam o ocaso das fronteiras nacionais e, no limite, do Estadonação ${ }^{191}$.

A democracia não parecia ser mais um problema à sociedade brasileira. Faltava ao país, contudo, integrar-se ao fenômeno da globalização. A liberalização econômica observada na América Latina ao longo da década de 1980, a despeito das idas e vindas que a caracterizaram nos diferentes contextos nacionais, foi compreendida como "um processo de expansão do capitalismo a partir de seu núcleo em direção à periferia do sistema"192. A partir disso, os rumos do Estado pareciam organizar-se em torno de diferentes utopias econômicas. Uma delas, proposta por diversos candidatos na corrida presidencial de 1989, envolvia a reafirmação e a racionalização do estatismo desenvolvimentista, a partir de uma lógica distributiva $^{193}$.

As outras utopias econômicas eram o neoliberalismo, de inspiração anglo-saxã (thatcheriana ou reaganista) e defensora do Estado mínimo ${ }^{194}$, e a chamada "integração

\footnotetext{
${ }^{190}$ Fukuyama

${ }^{191}$ Ohmae

192 (Sallum Jr, 2011, p. 259)

${ }^{193}$ Curiosamente, tratava-se de leitura oferecida tanto à direita, por presidenciáveis como Paulo Maluf (PDS), quanto nas distintas colorações à esquerda, de Lula a Leonel Brizola (PDT), passando pelo socialista Roberto Freire (PCB) ou pelo social-democrata Mário Covas (PSDB).

194 “Os governos da primeira-ministra Margaret Thatcher na Inglaterra e, depois, do presidente Ronald Reagan nos EUA adotaram uma gestão econômica de orientação monetarista, priorizando o combate à inflação em relação à preservação do emprego e dos rendimentos do trabalho, abandonando as diretrizes keynesianas. Aos poucos a política monetarista foi associada a outras propostas, como as da desregulação dos mercados, da redução dos gastos sociais e do intervencionismo do Estado, do equilíbrio das finanças públicas, do livre fluxo
} 
competitiva", projeto igualmente liberalizante que "diferenciava-se do neoliberalismo também por ser, ao contrário dele, uma forma de nacionalismo não defensivo, mas de afirmação nacional no plano internacional" ${ }^{\text {"195 }}$. Tratava-se, portanto, de um ideário defensor do Estado forte - não em suas funções empresariais, mas naquelas de coordenação e reestruturação do sistema produtivo brasileiro de forma a torná-lo competitivo no exterior, por meio de políticas industriais consistentes. Aquilo que, no plano econômico, pensou-se como integração competitiva, não será muito diferente, como veremos adiante, do conceito de autonomia pela modernização ligado à política externa, com a ressalva de que, no segundo caso, trata-se de uma modernização mais ampla, relacionada à toda a agenda internacional do país, não somente em seu aspecto de comércio exterior, finanças ou investimentos.

de capitais e de mercadorias, compondo - ou melhor, dando força política - ao neoliberalismo, doutrina existente, mas de pouca expressão, desde o após Segunda Guerra Mundial” (Sallum Jr., 2011, p. 264).

195 (Sallum Jr., 2011, p. 265) 


\section{CAPÍTULO 3}

\section{As viagens do presidente-eleito}

Uma vez confirmado o resultado das urnas, Collor programou duas viagens ao exterior. A primeira seria de cunho particular, composta por três etapas: passaria o Réveillon nas Ilhas Seychelles, na costa oriental africana, e visitaria Roma e Paris. A segunda, mais longa e em caráter oficial, teria quase um mês de duração, durante o qual o presidente eleito percorreria o Cone Sul, os Estados Unidos, o Japão, a União Soviética e diversos países europeus.

Debruçar-se sobre uma viagem de férias e descanso seria despropositado para os fins dessa tese, não houvesse um importante precedente histórico: Epitácio Pessoa, em 1919, estendeu sua permanência na Europa, onde se encontrava na condição de chefe da delegação brasileira à Conferência de Paz de Versalhes. Apesar de ser uma viagem de descanso, ela serviu ao presidente-eleito como um exercício de relações públicas, estabelecendo um padrão de comportamento da diplomacia presidencial brasileira, como bem demonstra Sérgio Danese $^{196}$. No caso de Collor, a despeito de se tratar de uma viagem de "férias" - bastante criticada domesticamente como uma "viagem de marajá"197 -decidiu-se realizar algumas reuniões de trabalho, encontrar-se com autoridades diplomáticas brasileiras e estrangeiras, talvez para minimizar os questionamentos sobre o luxuoso descanso no exterior.

\subsection{A viagem de férias}

Até o dia do embarque, o roteiro do presidente-eleito encontrava-se guardado a sete chaves, para evitar qualquer tipo de cobertura e especulação jornalística. Quem desfez o mistério sobre o paradeiro de Collor foi o embaixador do Brasil no Gabão, Jaime Villa-Lobos, que confirmou o destino a Seychelles após parada técnica na capital gabonesa, Libreville, no dia 30 de dezembro. Com essa escala, o Gabão tornou-se o primeiro país visitado pelo presidente após sua diplomação. Inadvertidamente, o embaixador brasileiro havia lhe preparado uma grande recepção, que pegara Collor de surpresa, às 4 da manhã no horário local, com todas as honrarias de chefe de Estado. "Teve até tapete vermelho", afirmou Villa-

\footnotetext{
${ }^{196}$ Danese, Sérgio. Diplomacia Presidencial. Rio de Janeiro: Topbooks, 1999, p. 260.

${ }^{197}$ De acordo com a coluna Painel, da Folha, do dia 02 de janeiro de 1990: "Segundo as más línguas de Brasília, Collor foi para Seychelles a fim de conhecer melhor o sistema de governo local. Lá, o presidente da República acumula as funções de ministro do Planejamento e das Relações Exteriores".
} 
$\operatorname{Lobos}^{198}$. De acordo com Cláudio Humberto Rosa e Silva, "na pista o aguardavam centenas de pessoas, desde tropas de soldados prontos para revista até grupos que representavam, vestidos - ou despidos - a caráter, com lanças, escudos, arcos e flechas nas mãos, as tribos bantu (...), fang, echira, aduma e ochandê, que formam a complicada composição étnica gabonesa" 199 . Sem registrar sua "imensa irritação" - nas palavras de Rosa e Silva - pela festa indesejada, o presidente eleito reuniu-se com grande comitiva de autoridades locais, chefiada pelo ministro das Relações Exteriores, Ali Bongo, filho de Omar Bongo, presidente do país. Para Villa-Lobos, o encontro havia sido "muito cordial", no qual se tratou de temas referentes à relação bilateral entre Brasil e Gabão ${ }^{200}$.

Depois de dois dias em Seychelles, o presidente e sua comitiva rumaram à Europa, com uma escala de cinco horas no Egito. Como sua viagem não era mais secreta, a exposição do roteiro do presidente eleito tornou-se ostensiva, e Collor buscou capitalizar a situação mostrando que se tratava de uma viagem de trabalho. Ao chegar a Roma, convocou seus dois economistas mais próximos, Zélia Cardoso de Mello e Daniel Dantas - este, indicado pelo excunhado de Collor, o empresário Olavo Monteiro de Carvalho, e referendado pelo ex-ministro Mário Henrique Simonsen - para uma rodada de conversas sobre o programa econômico do novo governo. A avaliação de Laurentino Gomes, no Estadão, era a de que as reuniões marcadas por Collor na capital italiana "agravaram as divergências" entre os dois principais conselheiros da área econômica. "Levados ao novo presidente por mãos diferentes, os dois disputam o tamanho da fatia de poder que devem ocupar no governo a partir do dia 15 de março e também imaginam soluções diferentes para os problemas enfrentados pela economia brasileira"201. Enquanto Dantas defendia um "choque violento" na economia para derrubar a inflação, Zélia acreditava que o remédio contra a escalada inflacionária deveria ser ministrado com rapidez, mas em doses mais homeopáticas.

Como já havia ocorrido na viagem à Europa como candidato, Collor aproveitou-se do palanque internacional para dar contornos à sua estratégia política. Confrontar e expor seus assessores - e, ao mesmo tempo, confundir analistas e espectadores, ansiosos como estavam por saber os rumos de uma economia em crise - atendia a duas necessidades: jogava uma cortina de fumaça sobre as reais intenções de ajuste do novo governo e impedia que qualquer figura ganhasse proeminência política. A declaração do presidente eleito, em Roma, era

\footnotetext{
198 OESP, “Collor passa réveillon no Oceano Índico”, 02 de janeiro de 1990, p. 4.

${ }^{199}$ Rosa e Silva, Cláudio Humberto. Mil Dias de Solidão: Collor bateu e levou. São Paulo: Geração Editorial, 1993, p. 257.

${ }^{200}$ FSP, "Collor passa final do ano nas ilhas Seychelles, leste da África”, 02 de janeiro de 1990, p. A-4.

201 OESP, "Planos de emergência dividem a equipe", 06 de janeiro de 1990, p. 5.
} 
bastante sintomática: "O ministro da Economia tem que se chamar Fernando Collor de Mello". Ao mesmo tempo, assumir todos os riscos (e potenciais benefícios) de chamar exclusivamente para si a responsabilidade do combate à inflação já criava problemas internos para o presidente eleito, poucas semanas após o fechamento das urnas.

Enquanto Collor voava para Paris, na terceira etapa de sua viagem de férias, o líder do PMDB no Senado, Ronan Tito, disparava que o novo mandatário estava fazendo "terrorismo econômico" ao manter sigilo sobre as medidas, e que a indefinição na política econômica não teria aval do legislativo: “o Congresso está aí para segurar qualquer besteira, qualquer estupidez que ele fizer". O senador aproveitou para criticar a viagem de Collor, de custo estimado entre US\$ 300 mil e US\$ $600 \mathrm{mil}^{202}$ : “Ele começou bem, indo para o Oceano Índico caçar marajás" "203. Impressão semelhante era compartilhada pelo líder do PMDB na Câmara, Ibsen Pinheiro, que criticou duramente a viagem "num momento em que o país está tenso"204. O desconforto encontrava eco nas páginas dos jornais: em editorial, a Folha de São Paulo declarava: "o presidente eleito cultiva a indefinição e o mistério, enquanto prolonga sua espetacular viagem de descanso (...). Tomadas isoladamente e sem maiores detalhes, [as medidas econômicas] apenas prolongam, no entrechoque das informações e dos rumores, a sensação generalizada de incerteza e obscuridade"205.

Ao passo que a viagem foi útil para manter certos políticos "adesistas" distantes do novo presidente logo após a vitória, ela começava a trazer custos políticos muito altos. As saídas de Collor ao exterior, até então símbolos de uma figura política cosmopolita, deixavam de ser úteis para os objetivos domésticos que buscava atingir ${ }^{206}$. Não deixa de ser simbólico, entretanto, a recepção dada a Collor pelo corpo diplomático brasileiro local: quando a comitiva desembarcou na capital francesa, foi recebida pelo embaixador na França, João Hermes Pereira de Araújo, pelo embaixador brasileiro na UNESCO, José Guilherme Merquior (ambos viriam a ser "ministeriáveis" nas semanas seguintes), Ruy Vasconcelos, cônsul-geral do Brasil, além de um representante do Quai d’Orsay, Philippe Franc ${ }^{207}$. Em

\footnotetext{
${ }^{202}$ Ver, também, FSP, "Quanto custa a viagem", 06 de janeiro de 1990, p. A-4.

${ }^{203}$ FSP, "Sigilo é terrorismo, diz Tito", 09 de janeiro de 1990, p. A-6.

${ }^{204}$ FSP, "Viagem ajuda a manter os políticos à distância", 07 de janeiro de 1990, p. A-7.

${ }^{205}$ FSP, “Ainda a indefinição”, 12 de janeiro de 1990, p. A-2.

${ }^{206}$ Nos dias que lhe restavam na Itália, o máximo que conseguiu foi cortejar autoridades católicas em Assis, cidade em que realizou um passeio turístico-religioso. "O momento mais solene foi diante da tumba de São Francisco, na basílica inferior do subsolo, Collor se ajoelhou e permaneceu imóvel e cabisbaixo durante alguns minutos. Depois fez o sinal da cruz e continuou o passeio". Em Paris, não houve nenhum encontro entre Collor e qualquer político local, tendo o presidente eleito se limitado a jantar com alguns assessores, como Cláudio Humberto, Renan Calheiros, presidente do PRN, e o deputado alagoano Cleto Falcão. FSP, "Collor descarta a antecipação da posse e promete crescimento", 06 de janeiro de 1990, p. A-4.

${ }^{207}$ OESP, "O reencontro com os filhos em Paris", 07 de janeiro de 1990, p. 4.
} 
Roma, Collor e seus acompanhantes haviam se hospedado na sede oficial da representação brasileira, Palazzo Pamphilj, a convite do embaixador Carlos Alberto Leite Barbosa. O Itamaraty passava a ostensivamente apoiar a transição presidencial, mesmo no contexto de uma viagem particular do presidente eleito.

A posição do Ministério das Relações Exteriores causava certa polêmica. O escritório de transição do novo governo já havia sido instalado no prédio do Anexo 2 do Itamaraty, o "bolo de noiva". Confrontado com um questionamento sobre o papel de diplomatas e funcionários do ministério nas viagens do presidente eleito, um diplomata tentou justificar: "Nós apenas auxiliamos na preparação da viagem", sem mencionar a mobilização em torno da viagem de férias de Collor à Europa. O embaixador Ruy Nogueira, porta-voz do MRE, explicou que todas as solicitações do novo presidente e de sua equipe seriam atendidas: "a diplomacia trabalha para o Estado e não para governos", afirmou. Além disso, o Itamaraty estava se articulando para a "operação gigantesca" da posse presidencial, que requeria o trabalho de todo o ministério e, em particular, de seu cerimonial ${ }^{208}$.

Aos poucos, Collor também foi se cercando de diplomatas de carreira. Se na longa turnê europeia durante a candidatura ele quis apresentar-se como independente, dispensando qualquer assessoramento técnico que não fosse o de sua conselheira econômica, Zélia Cardoso de Mello, nas viagens que faria oficialmente como presidente eleito - um périplo regional e um mundial - já entravam para sua comitiva, em caráter definitivo, dois servidores do Itamaraty: seu cunhado, embaixador Marcos Coimbra, coordenador da equipe de transição, e o ministro Gelson Fonseca Jr., que passaria a exercer o papel de assessor diplomático (e eventual ghostwriter) do presidente. Uma vez eleito, Collor buscava credibilidade ao flertar com o profissionalismo da burocracia do MRE, esquivando-se das recorrentes críticas quanto à falta de base partidária ou de sustentação política para empreender as reformas necessárias.

\subsection{A construção da agenda internacional}

A segunda viagem de Collor, em caráter oficial, dividia-se em duas etapas: uma viagem ao Cone Sul e outra aos centros de poder globais. Essa modalidade de viagem de presidente-eleito também possuía precedente histórico: Campos Sales havia sido o primeiro a fazê-lo, em 1898, sendo reproduzida por diversos outros presidentes ao longo do século

\footnotetext{
${ }^{208}$ OESP, "Novo governo mobiliza Itamaraty", 11 de janeiro de 1990, p. 4.
} 
$\mathrm{XX}^{209}$. Dois casos são emblemáticos do padrão conceitual da "diplomacia de transição". O primeiro é o de Juscelino Kubitschek, cuja viagem - em meio a uma crise política representou "a busca de alavancagem política internacional para o projeto econômico do governo que se iniciaria, fazendo o marketing externo do novo governo, e a evasão das pressões políticas pós-eleição" ${ }^{210}$. No caso de Tancredo Neves, trinta anos mais tarde, a ideia da turnê presidencial era a de "marcar, no plano internacional, o significado das transformações internas ocorridas em nosso país com o advento da Nova República"211.

Collor inaugurava um terceiro propósito da diplomacia de transição, que era a recomposição da credibilidade do Brasil no exterior - menos nas questões substantivas (democracia ou projetos econômicos) mas, sobretudo, no impacto positivo que sua imagem pessoal trazia. Era necessário descolar-se completamente daquilo que o governo Sarney se tornara. O curto intervalo entre as férias e o início das viagens internacionais foi marcado pelo aprofundamento da crise econômica e institucional no Brasil. Discutia-se seriamente a hipótese de se antecipar a posse, como forma de estancar a derrocada da popularidade de Sarney, cujo governo já beirava a ingovernabilidade. Não era a vontade de Collor $^{212}$, uma vez que a transição mal começara, não havia equipe e não se sabia exatamente como lidar com o quadro hiperinflacionário que se desenhava ${ }^{213}$. Ao mesmo tempo, a equipe do novo governo julgou por bem reduzir a duração da saída ao exterior, antes programada para 32 dias, para pouco mais de vinte ${ }^{214}$.

Havia questões práticas ligadas à economia, por exemplo, que não podiam esperar: mesmo após o prazo de dez dias dado por Collor a Zélia em Roma, e equipe econômica não

\footnotetext{
${ }^{209}$ Juscelino Kubitschek, Jânio Quadros, Costa e Silva e Tancredo Neves haviam também viajado na qualidade de presidentes-eleitos. A viagem de Tancredo Neves, em particular, mereceu detalhados relatos e análises. Ver, nesse sentido, Lafer, Celso. "O legado diplomático da viagem presidencial de Tancredo Neves". Contexto Internacional, vol. 2, no. 1, 1985; Ricupero, Rubens. Diário de Bordo: a viagem presidencial de Tancredo. São Paulo: Imprensa Oficial, 2010. Mais recentemente, publicou-se detalhada avaliação sobre a transição presidencial entre Fernando Henrique Cardoso e Luiz Inácio Lula da Silva. Ver Spektor, Matias. 18 Dias. Rio de Janeiro: Record, 2014.

${ }^{210}$ Danese, 1999, p. 318.

${ }^{211}$ Lafer, 1985, p. 13.

${ }^{212}$ FSP, "Collor descarta a antecipação da posse e promete crescimento", 06 de janeiro de 1990, p. A-4.

${ }^{213}$ O comentário de Dimenstein é ilustrativo: "Num tom descontraído e bem humorado, o presidente José Sarney tem feito uma aposta com amigos e auxiliares: 'Em três meses muita gente que me detestava vai sentir minha falta'. Diz mais: 'eles vão ficar chateados porque reduzi meu mandato de seis para cinco anos'. Ele imagina tempos difíceis para Fernando Collor, nublado por conflitos econômicos e políticos, duvidando que o sucessor será tão tolerante. Sarney está certo? Difícil saber (...). Não é fácil aplicar choques ortodoxos em regimes democráticos. Exigem sustentação política, força partidária, patronal e, sobretudo, congressual. Exige uma equipe ministerial sólida, experiente e competente para administrar o dia-a-dia de um choque. Até aqui, Collor não mostrou força partidária, congressual ou prestígio empresarial ou equipe ministerial. O que ajuda, por enquanto, a aposta de Sarney". Dimenstein, Gilberto. "A aposta de Sarney", Folha de São Paulo, 06 de janeiro de 1990, p. A-2.

${ }^{214}$ FSP, "Viagem ajuda manter...", p. A-7.
} 
havia conseguido chegar a um consenso em torno de um projeto - nem mesmo nas suas medidas básicas e mais urgentes. Se a indefinição quanto a esse plano econômico havia sido instrumental nos primeiros dias após a eleição, ela começava a pesar sobre os ombros do presidente eleito, gerando incertezas entre críticos e, até mesmo, entre simpatizantes. A poucos dias de embarcar para a primeira parada internacional, no próprio Cone Sul, Jânio de Freitas comentava: “O problema, posto cruamente, é que o objeto central das desconfianças é o próprio Collor. Ninguém sabe o que, a que e a quem representará no exercício da Presidência (...). É até curioso como as desconfianças em relação a Collor estão difundidas, são um ponto de comunhão imprevista dos seus adversários e dos seus apoiadores eleitorais" 215 .

Explica-se, assim, a decisão de abreviar o roteiro sul-americano a uma "viagem relâmpago" de pouco mais de 24 horas, iniciada no dia 21 de janeiro. Era a única maneira de atender aos convites oficiais de Carlos Menem, presidente argentino, Luís Alberto Lacalle, do Uruguai, e Andrés Rodríguez, presidente eleito do Paraguai. Nos três casos, Collor de Mello tinha uma agenda muito semelhante, que envolvia a discussão sobre a dívida externa e os altos índices de inflação na região, bem como a necessidade de se aprofundar a integração latino-americana, embora houvesse, também, particularidades bilaterais a serem abordadas nas conversas.

O café da manhã com Menem, por conseguinte, refletiu o estado de espírito dos dois países - dois gigantes sul-americanos mergulhados em crise ${ }^{216}$. Empossado em julho de 1989, o presidente argentino já havia realizado duas "cirurgias sem anestesia" para conter a febre hiperinflacionária que castigou a economia do país, sem sucesso. Na primeira delas, procedeu à maxidesvalorização do Austral, tarifazo e congelamento de preços. Na segunda, confiscou depósitos bancários a prazo fixo, de modo a enxugar os meios circulantes, e deu calote da dívida pública interna, convertendo-a em Bonos da Dívida Externa (Bonex), a serem pagos em 10 anos. $\mathrm{O}$ fracasso das medidas obrigou Menem a mudar o ministro da Economia duas vezes no curto período de seis meses. Logo depois da visita de Collor, o atual chefe da pasta econômica, Antonio Ernan González, empossava o quarto presidente do Banco Central $\operatorname{argentino~}^{217}$. O país estava à beira de uma crise de confiança e do retorno da hiperinflação ${ }^{218}$.

Por isso mesmo, era tão crucial para a Argentina manter o caminho da integração política e econômica iniciada por Sarney e Raúl Alfonsín, poucos anos antes. Em frangalhos,

\footnotetext{
${ }^{215}$ De Freitas, Jânio. “Ainda é uma esfinge”, Folha de São Paulo, 17 de janeiro de 1990, p. A-5.

${ }^{216}$ Ver Rossi, Clóvis. "Menem, o tênis e Collor”, Folha de São Paulo, 17 de janeiro de 1990, p. A-2.

${ }^{217}$ FSP, "Folcini é o quarto presidente do BC argentino do governo Menem", 24 de janeiro de 1990, p. B-6.

${ }^{218}$ Beting, Joelmir, "O choque do engodo", Folha de São Paulo, 23 de janeiro de 1990, p. B-2.
} 
a economia argentina dependia da aproximação com o Brasil como forma de restabelecer-se nos trilhos. Mais que isso: a convergência programática entre Menem e Collor poderia ser um importante mote na coordenação de políticas econômicas entre ambos os países ${ }^{219}$. A mensagem de Humberto Toledo, porta-voz da presidência argentina, deve ser lida neste contexto: "o projeto do presidente Menem é seguir a passos largos com protocolos que estimulem a aproximação" ${ }^{, 220}$. Collor parecia compactuar da mesma ideia. Defendendo que a integração não ficasse somente no plano retórico, o presidente eleito defendeu, junto a Menem, o rápido estabelecimento de um mercado comum latino-americano, "fundamental para que possamos fortalecer o processo democrático na solução de nossos problemas" ${ }^{221}$.

Para Collor, tratava-se de muito mais do que somente uma questão de princípios. Havia um temor real de que o Brasil fosse acometido pelo "efeito Orloff", termo do anedotário econômico segundo o qual o país viveria, com certo atraso, as experiências argentinas. Talvez o ponto mais importante da rápida passagem de Collor por Buenos Aires tenha sido, portanto, o conselho dado a ele por Menem: na visão do presidente argentino, a preocupação com a popularidade deveria ser secundária no início do governo. Collor deveria tomar de imediato as medidas necessárias para o combate à inflação, mesmo que fossem amargas e, caso trouxessem impopularidade, o restante do mandato poderia ser utilizado para se recuperar o prestígio ${ }^{222}$.

A próxima parada do presidente eleito era Montevidéu, capital uruguaia, onde se encontrou rapidamente com o presidente Julio María Sanguinetti no palácio presidencial. Sem uma pauta concreta para tratar - Sanguinetti entregaria o cargo a seu sucessor, Luís Alberto Lacalle, em poucos meses -, ambos discutiram questões protocolares, sendo que Collor aproveitou para reiterar sua defesa da formação de um mercado comum latino-americano, aproveitando-se de estruturas logísticas já existentes, como a hidrovia Paraguai-Paraná223. Após uma rápida passagem pela sede da Associação Latino-Americana de Desenvolvimento e Integração (ALADI), o presidente eleito rumou a Punta del Este, ao encontro de Lacalle. No almoço com seu contraparte - que declarara, dias antes, que tinha "várias afinidades em

\footnotetext{
219 Domingo Cavallo, ministro das Relações Exteriores e peça-chave na formulação das políticas macroeconômicas argentinas, apontou semelhanças entre o plano exposto por Collor e as diretrizes econômicas de seu país: políticas fiscais que eliminem os déficits, abertura das economias ao exterior para aumentar a competitividade industrial, integração aprofundada até a formação de mercado comum, economia onde a iniciativa privada seja protagonista -essas coincidências, segundo o ministro, ajudariam a colocar em prática o protocolo 24 assinado por Brasil e Argentina, que prevê a coordenação das políticas macroeconômicas. Ver FSP, "Chanceler vê pontos comuns nos dois planos", 22 de janeiro de 1990, p. A-5.

${ }^{220}$ FSP, "Menem pedirá que Collor continue a integração iniciada por Sarney", 18 de janeiro de 1990, p. A-10.

${ }^{221} \mathrm{JB}, 22$ de janeiro de 1990.

${ }^{222}$ FSP, "Para Menem, Collor deve adotar medidas amargas", 22 de janeiro de 1990, p. A-5.

${ }^{223}$ FSP, "No Uruguai, união da AL é tema central”, 22 de janeiro de 1990, p. A-4.
} 
diferentes áreas" com Collor ${ }^{224}$ - também foram discutidas questões ligadas à integração latino-americana. Naquela oportunidade, destacou-se a necessidade de adaptar o arcabouço jurídico da ALADI - um "mecanismo idôneo para que a integração deixe de ser uma retórica, para converter-se em uma realidade", nas palavras do presidente eleito uruguaio - para aprofundar a aproximação entre os países.

A pauta com o presidente paraguaio, Andrés Rodríguez, foi mais específica do que com as demais autoridades visitadas por Collor. Não se falou de democracia ou integração latino-americana, uma vez que o Paraguai ainda vivia um governo provisório, após o golpe de Estado comandado pelo general Rodríguez que depôs o ditador Alfredo Stroessner. O tema que marcou a conversa bilateral foi a questão dos brasiguaios - colonos brasileiros atraídos ao Paraguai pelo governo Stroessner, nos anos 1970, quando se pretendia aumentar a produção de grãos, sobretudo soja, para exportação. Com o fim da ditadura, em 1989, os movimentos sociais paraguaios, em particular o movimento campesino, começam a organizarse e a pressionar o novo governo a frear o movimento de expansão de investimentos e fluxos migratórios para a fronteira "movediça" do Paraguai ${ }^{225}$. Naquele mesmo ano, o senado aprovou o projeto de lei do senador Rodolfo González Garabelli, estabelecendo uma "faixa de segurança" de 50 quilômetros ao longo da fronteira paraguaia como "zona exclusiva" para nacionais. Essa medida era particularmente problemática ao Brasil, pois envolvia a expropriação de terras arrendadas por brasileiros no Paraguai, bem como a expulsão de praticamente 350 mil brasiguaios da região, o que potencialmente causaria problemas econômicos e sociais. Decidido a manter boas relações com o Brasil, país de quem o Paraguai dependia em grande parte de suas atividades econômicas, Rodríguez prometeu a Collor articular a derrubada do projeto de lei, caso ele não fosse vetado pela Câmara ${ }^{226}$.

Desde o princípio, sabia-se que a visita de Collor aos países vizinhos era muito mais um ato simbólico do que um encontro pragmático, com pautas extensas e projetos conjuntos. Em geral, as conversas foram limitadas a platitudes, gentilezas e à reafirmação de um processo de integração econômica que parecia fundamental às nações do Cone Sul, até mesmo como maneira de se contrapor ao fortalecimento dos grandes blocos econômicos que se organizavam na Europa, na Ásia e na América do Norte. A avaliação de Newton Rodrigues nos parece correta e adequada:

\footnotetext{
${ }^{224}$ FSP, "Lacalle diz ter 'afinidades' com Collor", 20 de janeiro de 1990, p. A-5.

${ }^{225}$ Albuquerque, José L. C. "Campesinos paraguayos y 'brasiguayos' em la frontera este del Paraguay". In: Fogel, Ramon e Riquelme, Marcial. Enclave sojero, merma de soberania y pobreza. Assunção: CERI, 2005, p. 158.

${ }^{226}$ FSP, "Presidente paraguaio promete vetar expulsão", 23 de janeiro de 1990, p. A-7.
} 


\begin{abstract}
"Um gesto de boa vontade. Assim pode ser classificada a viagem de Fernando Collor aos países do Cone Sul, uma vez que dela nada de mais concreto se poderia esperar (...). Como afirmação política, entretanto, a excursão foi um êxito, indicando interesse por uma política de entendimento continental, mais necessário depois da invasão norte-americana no Panamá e da abertura ao Leste, que não terá consequências favoráveis aos investimentos no Brasil",227
\end{abstract}

Antes de embarcar para a próxima etapa da viagem oficial, Collor concedeu sua segunda entrevista coletiva. Muitas das perguntas giraram em torno da conjuntura internacional que seria enfrentada pelo novo governo. A dívida externa foi objeto da primeira pergunta, motivada pela decisão do Eximbank de colocar o Brasil na lista de altíssimo risco, no mercado financeiro internacional, dada a situação de virtual moratória brasileira. $\mathrm{O}$ presidente eleito foi taxativo:

\begin{abstract}
"Ontem, em contato mantido com o Sr. David Mulford, subsecretário do Tesouro americano, eu desse a ele que nessa viagem que nós estaremos iniciando hoje, eu desejo conhecer as pessoas com as quais nós iremos renegociar, de uma forma ampla, a nossa dívida externa. Não estaremos levando nenhuma proposta objetiva (...). Disse ao Sr. Mulford que na primeira semana depois da nossa posse nós estaríamos em Washington, levando a nossa proposta (...) [que] obedeceria fundamentalmente a um parâmetro: nós não podemos abrir mão do nosso crescimento econômico. Não se trata, portanto, de saber quanto nós poderemos crescer, depois de pagar a nossa dívida externa, mas sim de quanto poderemos pagar depois de garantido o nosso crescimento econômico",228
\end{abstract}

A próxima pergunta sobre política externa dizia respeito ao Panamá. O jornalista da Associated Press recordou a posição de Collor, na primeira coletiva, extremamente crítica à invasão norte-americana. Diante da ofensiva diplomática dos EUA para minimizar os danos entre os aliados da América Latina, questionou-se se o presidente eleito continuaria "como crítico ou já começa a atuar como presidente do Brasil, necessitado da ajuda financeira americana". Nessa resposta, o candidato tergiversou:

\footnotetext{
"Eu costumo tomar as minhas atitudes observando única e exclusivamente as questões filosóficas que envolvem um acontecimento, como esse ocorrido agora no Panamá. E a minha crítica, no momento em que se realizou essa invasão, não foi aos Estados Unidos da América. Foi a qualquer país de nosso continente. Seria a qualquer entidade que estivesse ferindo um dispositivo fundamental da boa convivência entre as nações, entre os nossos povos, que é a autodeterminação de cada um dos países (...). Fundamentalmente, isso foi ferido com essa invasão do Panamá, sem outras considerações quaisquer".
}

\footnotetext{
${ }^{227}$ Rodrigues, Newton. "Um quisto a extirpar". Folha de São Paulo, 23 de janeiro de 1990, p. A-2.

${ }^{228}$ OESP,"Veja íntegra da coletiva de imprensa", 25 de janeiro de 1990, p. 7.
} 
Integração latino-americana e a formação dos grandes blocos econômicos foram o tema da terceira pergunta sobre política externa. O correspondente da France Presse quis saber como o Brasil conseguiria captar investimentos, diante do quadro de ascensão da Europa do Leste. Collor apostou na integração competitiva para sustentar a viabilidade da economia brasileira no longo prazo:

“A unificação do mercado ou dos nossos mercados, sem dúvida fortalecerá a
democracia no continente e agilizará o desenvolvimento econômico e social de toda
essa nossa região (...). Mas, se de um lado nós brasileiros e nós latino-americanos,
temos que receber com esse entusiasmo e com aplauso o que vem acontecendo lá no
Leste Europeu (...), isso nos traz uma certa apreensão do ponto de vista econômico,
porque, é claro, o nosso continente deixa de ser o único captador de investimentos e
capitais externos (...). É por isso que, mesmo no decorrer da campanha (...) eu já
dizia que nós tínhamos que fazer do Brasil um país competitivo. Que nós tínhamos
que nos integrar competitivamente à economia mundial”.

A posição sobre ecologia manteve-se rigorosamente igual àquela defendida ao longo da campanha, repetindo-se, inclusive, as mesmas frases de efeito utilizadas ao longo dos meses anteriores. Ao ser perguntado sobre a polêmica proposta do imposto sobre poluição, Collor respondeu:

\footnotetext{
"Naturalmente, essa proposta foi bem vista por países que não poluem tanto e não foi bem vista por países que poluem muito, porque isso retira a máscara, até certo ponto cínica, da maneira como vêm conduzindo essa questão ecológica aí fora (...). Os países industrializados têm uma grande parcela de culpa nesse transtorno ambiental que vem sendo causado ao nosso planeta (...). Eu acho que todos nós temos que nos sentar numa mesa, conversarmos clara e abertamente, sem acusações mútuas e recíprocas e encontrarmos modos, maneiras de nos ajudarmos mutuamente. Os países industrializados, naturalmente, por disporem de maior tecnologia, de maior técnica, oferecendo aos países menos desenvolvidos estas mesmas tecnologias para preservação ambiental, sem a cobrança, naturalmente, de "royalties", já que isso é do interesse de toda humanidade, de todo o planeta"
}

\subsection{A longa viagem de presidente-eleito}

A primeira parada de Collor em seu segundo périplo internacional foi nos Estados Unidos, no dia 25 de janeiro. Embora as relações viessem melhorando desde o início do governo Bush, restavam importantes divergências bilaterais, tanto ligadas à dívida externa quanto às questões de propriedade intelectual - das quais se destacavam as patentes farmacêuticas e a legislação de informática. $\mathrm{Na}$ viagem, contudo, o presidente eleito queria dar-lhes contornos políticos, para além das questões técnicas que haviam orientado a agenda bilateral até então. Por isso mesmo, não interessava a Collor levar aos Estados Unidos propostas objetivas sobre os contenciosos. "Não tenho nenhum interesse de descer a detalhes 
nessa viagem", declarou o presidente eleito, no dia anterior ao embarque ${ }^{229}$. Além destes temas, entrariam para a pauta os investimentos norte-americanos na América Latina e no Brasil, principalmente diante do contexto de abertura do Leste Europeu, como também a questão ecológica, da qual Collor havia feito sua bandeira de campanha.

Tratava-se, claramente, de uma viagem mais importante para o convidado do que para o anfitrião. Desde o princípio, a Casa Branca caracterizou a visita de Collor de Mello ao país como "um encontro preliminar, uma cortesia" 230 , marcado pela compreensão de que não era possível encaminhar nenhuma questão substantiva até que o presidente eleito fosse empossado. De todo modo, a administração Bush guardava certa expectativa, por saber que a recuperação das boas relações bilaterais com o Brasil fazia parte do plano mais amplo do presidente norte-americano de reposicionar a América Latina como região estratégica para os Estados Unidos. Não era o bastante, contudo, para despertar interesses maiores na opinião pública local: a imprensa norte-americana ignorou a visita do presidente eleito ontem a Nova York, sendo que nem os principais jornais nem as maiores redes de TV noticiaram a chegada de Collor e sua comitiva na cidade ${ }^{231}$.

A agenda de Collor no coração financeiro dos EUA envolveu dois encontros importantes. O primeiro deles foi com a comunidade judaica norte-americana. Em reunião com o presidente e o secretário-geral do Congresso Mundial Judaico (World Jewish Congress), Edgar Bronfman e Israel Singer, além do presidente da Confederação Israelita do Brasil (CONIB), Benno Milnitzky e o rabino Henry Sobel, da Congregação Israelita Paulista (CIP), o presidente Fernando Collor afirmou que o Brasil cometeu um erro ao votar nas Nações Unidas, em 1975, a favor da Resolução 3379, que considerava o sionismo uma forma de racismo - ajudar a revoga-la teria sido uma promessa de Tancredo Neves, que não viveu para cumpri-la, de acordo com Sobel. No encontro, Bronfman ressaltou a posição do Congresso Judaico de defender os interesses da América Latina e do Brasil, valendo-se do lobby judaico para evitar qualquer desvio de investimentos da região para o Leste Europeu, como se vinha discutindo nos Estados Unidos ${ }^{232}$.

Ao fim, Sobel lembrou o compromisso de Collor, assumido em campanha, de não conceder status diplomático ao atual escritório da OLP no Brasil. Para o rabino, a imagem de moderação que a OLP tentava projetar naquele momento escondia as facções que ainda defendiam a eliminação do Estado de Israel. A gafe diplomática cometida por Collor alguns

\footnotetext{
${ }^{229}$ FSP, "Eleito não leva propostas sobre dívida", 25 de janeiro de 1990, p. A-6.

${ }^{230}$ FSP, "Para Casa Branca, reunião é só uma "cortesia"”, 24 de janeiro de 1990, p. A-6.

${ }^{231}$ FSP, "Jornais dos EUA ignoram a visita de Collor ao país", 26 de janeiro de 1990, p. A-7.

${ }^{232}$ FSP, "Para Collor, Brasil errou a votar contra o sionismo", 26 de janeiro de 1990, p. A-7.
} 
meses antes ainda cobrava seu preço. No dia seguinte, o representante no Brasil da OLP, Ahmad Sobeh, disse que não pretendia criar polêmica com o governo brasileiro, e que o assunto seria tratado "respeitosamente, sem qualquer tipo de pressão" após a posse, "pois estamos num país amigo",233.

O segundo encontro de Collor em Nova York foi com representantes dos maiores empresários norte-americanos, com quem o presidente eleito estava disposto a dialogar. A reunião-almoço foi patrocinada pela Sociedade das Américas (Americas Society), presidida por David Rockefeller (ex-presidente do Conselho Diretor do Chase Manhattan) e pela Brazilian-American Chamber of Commerce, duas organizações mantidas por grandes empresas com interesses da América Latina ${ }^{234}$. O discurso de Collor, redigido por Zélia e Gelson Fonseca Jr., propunha uma retórica moderada com relação à dívida externa, mas mantendo as tradicionais posições de manutenção do interesse nacional e de retomada das negociações somente quando se criassem condições econômicas para tal.

Para o presidente eleito, seria fundamental enfrentar o problema da dívida, estabelecendo-se condições de negociação que incorporassem a "necessidade impostergável" do desenvolvimento econômico. "Não temos a ilusão de poder impor unilateralmente um caminho de negociação, mas não podemos aceitar imposições, acordos que se assemelhem a contratos de adesão e que, impedindo nosso crescimento econômico, nos condenem ao atraso e à miséria”. Collor aproveitou para denunciar a negligência dos países desenvolvidos com relação à América Latina, onde o problema da dívida externa continuava a "gerar efeitos econômicos devastadores e a elevar a níveis críticos os riscos de inquietação social”. Fazia referência direta, além do Brasil, às críticas situações da Argentina e da Venezuela. "É responsabilidade tanto dos devedores, como dos credores, encontrar uma saída sensata, balanceada e construtiva" para a questão. Por fim, o presidente eleito conclama a comunidade internacional a encarar as nações latino-americanas sob uma nova ótica:

\footnotetext{
"não mais como uma vaga aglutinação de realidades nacionais mal diferenciadas, e sim como uma região que, apesar da enorme diversidade de cada um dos Estados que a compõem, está se transformando num espaço humano e geográfico cada vez mais integrado política e economicamente, sob a égide da democracia conquistada",235.
}

\footnotetext{
${ }^{233}$ FSP, "Sionismo - 2", 27 de janeiro de 1990, p. A-7.

${ }^{234}$ FSP, "Collor faz sucesso com empresários em NY", 26 de janeiro de 1990, p. A-5.

235 Discurso de Fernando Collor de Mello em encontro promovido por David Rockefeller, em Nova York, 25 de janeiro de 1990. FSP, "Nossos indicadores sociais não mais ensejam qualquer otimismo", 26 de janeiro de 1990 , p. A-6.
} 
Da reunião com o empresariado norte-americano - que causou "muito boa impressão", nas palavras de Rockefeller ${ }^{236}$-, Collor embarcou para Washington, onde se reuniu, na manhã do dia 26, com o presidente Bush e seus principais assessores ${ }^{237}$. A secretaria de imprensa da Casa Branca emitiu comunicado, após o encontro, dizendo que Bush "reconheceu o importante papel do Brasil nos assuntos hemisféricos", "manifestou seu forte apoio aos planos do presidente eleito Collor para reformar e revitalizar a economia brasileira", e "afirmou que os Estados Unidos trabalharão próximos ao Brasil em direção a esse objetivo" ${ }^{238}$. A jornalistas, o porta-voz adjunto do governo Bush, Roman Popadiuk, disse que o presidente norte-americano havia ficado impressionado com Collor e disse que faria de tudo para incluir o Brasil no Plano Brady, que passaria a se chamar Plano Bush. O embaixador em Washington, Marcílio Marques Moreira, revelou que Collor reagiu positivamente à proposta, e que a sintonia entre os dois presidentes levou o americano a mudar seus planos e convidar a comitiva brasileira para um jantar não-programado na Casa Branca ${ }^{239}$.

À saída da reunião, o secretário Baker disse que Collor havia se mostrado "vigoroso e decidido" em sua agenda liberalizante e modernizadora. Opinião semelhante foi dada por Bernard Aronson, subscretário de Estado para América Latina, que foi além: "parece-me que [Collor] realmente vai cumprir sua plataforma apresentada na campanha presidencial. Pareceme também que, por isso, vai se encaixar na categoria dos melhores presidentes da América Latina, ao lado de Oscar Arias, da Costa Rica, e Salinas de Gortari, do México"240. A estratégia de construção da credibilidade presidencial estava, pelo visto, surtindo o efeito desejado. A esse respeito escreveu o professor da UFRJ, Arnoldo Wald:

"No momento em que parecia que a América Latina tinha perdido qualquer
possibilidade de retomar um lugar na formação dos grandes blocos multinacionais
que está ocorrendo nos últimos anos, o Brasil afirmou sua presença e sua
importância política, num discurso novo, que sensibilizou as mais altas autoridades
americanas (...). Com a nova sensibilidade que orienta agora as entidades
internacionais, com uma decisão política dos principais governos estrangeiros de
rever a posição brasileira, com a credibilidade que nosso país pode alcançar no
exterior, tomando as medidas institucionais que se impõem e dando-lhes

${ }^{236}$ FSP, "Collor faz sucesso..."; FSP, "Banqueiro chama Collor de "caçador de marijuana", 26 de janeiro de 1990 , p. A-6.

${ }^{237}$ Do lado brasileiro, estavam, além do presidente eleito, Zélia Cardoso de Mello e os embaixadores Marcos Coimbra, chefe do gabinete de transição, e Marcílio Marques Moreira, embaixador em Washington. Do lado norte-americano, acompanhavam o presidente Bush o secretário de Estado, James Baker, Marlin Fitzwater, porta-voz da Casa Branca, e John Sununu, chefe de gabinete.

${ }^{238}$ The Bush Presidential Library, "Statement by Press Secretary Fitzwater on President Bush's Meeting With President-Elect Fernando Collor de Mello of Brazil”, 26 January 1990. Disponível em http://bushlibrary.tamu.edu/research/public _papers.php?id=1477\&year=1990\&month=01

${ }^{239}$ FSP, "Bush propõe plano para reduzir dívida do Brasil e recebe casal Collor em jantar na Casa Branca", 27 de janeiro de 1990, p. A-5.

${ }^{240}$ FSP, “Discurso agrada funcionários dos EUA", 27 de janeiro de 1990, p. A-7. 
continuidade, é possível que, no futuro, o Plano Brady renegociado, ampliado e transformado em Plano Bush provoque, para o Brasil, uma reversão de expectativas análoga à que ensejou o Plano Marshall para os países europeus logo após a Segunda Guerra Mundial"241.

No dia 28 de janeiro, Collor chegou a Tóquio, capital daquela que era, à época, a segunda economia do mundo. Com uma balança comercial fortemente superavitária e um produto interno bruto correspondente a mais da metade do norte-americano, os japoneses transformavam suas enormes reservas cambiais em maciços investimentos em vários pontos do planeta. "Nenhum país carente de recursos pode pensar hoje em atrair capitais externos sem colocar o Japão no topo da lista de prioridades", afirmava editorial d'O Globo, no contexto da viagem de Collor ${ }^{242}$. O relacionamento com os nipônicos, contudo, não vinha de uma década próspera:

\begin{abstract}
O fenômeno da dívida externa, os problemas internos causados pelas altas taxas de inflação, somados a instabilidade econômica, esfriaram o relacionamento entre os dois países. Além disso, os interesses das empresas japonesas passaram por mudanças, deslocando a prioridade para a defesa de mercado para os seus produtos. A atenção japonesa voltou-se para os países desenvolvidos - principais mercados às exportações japonesas - que ameaçavam impor medidas protecionistas contra importações. Por causa dessa nova preocupação os países supridores de matériasprimas e recursos naturais, como o Brasil, passaram para um segundo plano ${ }^{243}$.
\end{abstract}

Com efeito, o Brasil - que recebia, no começo dos anos 1980, algo em torno de $10 \%$ dos investimentos japoneses no exterior - fechou a "década perdida" com menos de $1 \%$ destas inversões. O Panamá, por suas características de paraíso fiscal apto a abrigar as frotas mercantes japonesas e facilitar a internacionalização dos bancos japoneses, passou a concentrar mais da metade das aplicações nipônicas, ao fim do período. O desafio do Brasil, portanto, era "conseguir fazer-se integrar ao processo de globalização da economia japonesa" ${ }^{244}$. Aos olhos do Japão, havia um problema de credibilidade: o governo Sarney havia sido o grande responsável pela degeneração da imagem brasileira, transformando o Brasil "no país mais ocidental da África", contraindo dívidas sem o compromisso de pagá-las. Nos idos de 1989, o Japão concentrava nada menos que $17 \%$ da dívida brasileira, sendo o segundo maior credor do Brasil, atrás dos Estados Unidos. Assim, reconquistar a credibilidade

\footnotetext{
${ }^{241}$ Wald, Arnoldo. "O Plano Bush”. O Globo, 3 de fevereiro de 1990, p. 4.

242 “Laços com o Japão”. O Globo, 3 de fevereiro de 1990, p. 4.

${ }^{243}$ Uehara, Alexandre Ratsuo. "Relações Brasil-Japão: aproximações e distanciamentos”. Carta Asiática, 1999.

${ }^{244}$ Schwartz, Gilson. “O Brasil que sabe dizer sim: caminhos em direção ao Japão”. São Paulo em Perspectiva, vol. 4, no. 3, 1991, p. 24.
} 
do país perante empresários e políticos japoneses deveria ser, segundo o deputado Delfim Neto (PDS-SP), a prioridade do novo governo ${ }^{245}$.

A estratégia de Collor passava, à semelhança do que havia empreendido nos EUA, pelo restabelecimento da confiança no governo brasileiro. No caso japonês havia, além da questão da dívida e das dificuldades econômicas que se acumulavam, um contencioso específico, ligado à Usiminas. Através de mudanças no capital da estatal de siderurgia, a participação dos sócios japoneses da Nippon Steel foi reduzida, o que gerou reações negativas entre os empresários nipônicos. Era de se esperar, por conseguinte, que o presidente eleito se envolvesse numa agenda intensa. Nos dois dias em que ficou no país, encontrou-se com o primeiro-ministro, Toshiki Kaifu, e visitou o imperador Akihito no Palácio Imperial - uma deferência a Collor, já que era praxe que o chefe de Estado japonês só recebesse líderes empossados. Além disso, sentou-se com representantes governamentais, como Takashi Tanaka, do Eximbank japonês, e Mitsuhide Yamaguchi, do Fundo Econômico de Cooperação Internacional, com os quais negociou a liberação de US\$ 1,4 bilhão destinados a projetos de infra-estrutura no Brasil. Reuniu-se, por fim, com empresários japoneses no Keidanren - a Federação das Organizações Econômicas do Japão - e, na sede do Banco de Tóquio, com representantes dos dez bancos credores do Brasil, cujo montante de empréstimos somava, à época, nada menos que US\$ 12 bilhões $^{246}$.

Aos representantes do setor industrial nipônico, Collor fez um discurso incisivo em defesa da economia de mercado e dos privilégios cartoriais para alguns setores. O presidente eleito defendeu a privatização das empresas estatais, sugerindo o estabelecimento de mecanismos de conversão da dívida externa em investimentos. Sinalizou, também, para a abertura do mercado brasileiro para a indústria automobilística japonesa, que se encontrava em franca expansão. Aos banqueiros, Collor afirmou o que havia dito em Nova York, alguns dias antes: seu governo não se nega a pagar a dívida, mas condiciona a quitação dos atrasados e dos juros às necessidades de implantação de um programa que assegure níveis razoáveis de crescimento $^{247}$. Em discurso mais geral realizado no National Press Club japonês, além da reafirmação da necessidade de reforma do Estado, o presidente eleito voltou a insistir na tese da responsabilidade coletiva sobre o subdesenvolvimento:

"Quem se limitasse ao acompanhamento dessas grandes notícias [ligadas ao fim da Guerra Fria] poderia até acreditar que a História agora caminha numa direção única

\footnotetext{
${ }^{245}$ FSP, “Japoneses desconfiam do Brasil, diz Delfim”, 28 de janeiro de 1990, p. A-8.

${ }^{246}$ FSP, "Collor tentará atrair investimentos do Japão", 28 de janeiro de 1990, p. A-8.

${ }^{247}$ OESP, “Collor abre país para carros japoneses", 30 de janeiro de 1990, p. 4.
} 
e positiva, ou até mesmo se deixar levar pela euforia e pedir que fiquemos onde estamos, num imaginado fim da História. No universo da realidade, as condições em que vive a maioria dos seres humanos deixa muito a desejar. Se a capacidade de resolver problemas aumentou, também aumentaram a diversidade e a dimensão desses mesmos problemas. A comunidade internacional tem diante de si a necessidade imperiosa de encontrar uma saída para o impasse do subdesenvolvimento" 248 .

$\mathrm{Na}$ entrevista que concedeu logo depois, Collor tocou na questão ambiental, uma das tônicas de sua agenda externa. Voltou a frisar que o Brasil desejava discutir o tema de maneira "ampla, franca e aberta", contando com o envolvimento da comunidade internacional para promover a transferência de tecnologia no combate às emissões de gases tóxicos e qualificar o debate global ecológico. "Nós contamos firmemente com o apoio dos países industrializados como o Japão, país amigo, país que vem sendo solidário em todos os instantes com o Brasil e que poderá em muito ajudar esse projeto de preservação ambiental do nosso planeta" 249 .

Ainda que simbólicos, alguns resultados foram observados imediatamente. O primeiro-ministro Kaifu prometeu, ao fim de seu encontro com o presidente eleito, a liberação de US\$ 480 ao Brasil logo depois da posse, destinados ao financiamento de projetos de irrigação no Nordeste. O empresariado nipônico, pela figura do presidente da Sony, Akio Morita, também mostrou-se entusiasmado com a "juventude e a firmeza" do próximo presidente brasileiro, levando os japoneses a acreditar que o futuro governo dará boa oportunidade para os investimentos privados vindos do Japão. Otimistas também ficaram os representantes dos credores privados, que consideraram a possibilidade de uma renovada contribuição japonesa para o desenvolvimento brasileiro "se os acordos com o FMI e o Banco Mundial avançarem"250.

O próximo destino do novo presidente era a União Soviética - um país em crise, acumulando problemas financeiros e políticos desde a invasão do Afeganistão, uma década antes, e intensificados pela queda do muro de Berlim, havia poucos meses. Gorbachev, o reformista que mudara radicalmente a maneira como os soviéticos eram encarados pelo mundo ocidental, estava vendo suas reformas tomarem rumos imprevisíveis e desconhecidos. Muitas delas, em vez de apaziguar a população, suscitaram manifestações nacionalistas em diversas repúblicas soviéticas, do Azerbaijão aos países do Báltico e exigiram do governo respostas violentas. Ao contrário de outros tempos, os soviéticos precisavam de apoio político

\footnotetext{
${ }^{248}$ OESP, "Vamos reexaminar as funções do Estado", 30 de janeiro de 1990, p. 5.

249 OESP, "Meio ambiente nos preocupa", 30 de janeiro de 1990, p. 5.

${ }^{250}$ OESP, “Japão emprestará US\$ 480 milhões”, 30 de janeiro de 1990, p. 5.
} 
e econômico internacional - e, na relação com o Brasil, o pragmatismo dava lugar à ideologia, fator que impedira aproximações maiores nos governos anteriores. Noenio Spinola dava a dimensão da importância do Brasil nesse contexto:

\begin{abstract}
"Collor de Mello certamente ouvirá de Gorbachev seu interesse em um ponto: a URSS quer o apoio político do Brasil (e, neste caso, o Brasil pesa) para promover o desarmamento e suas ofensivas nos teatros de guerra europeus. A resposta ocidental tem sido lenta aos olhos de Moscou, onde há pressa para trocar canhões por manteiga",251.
\end{abstract}

A expectativa, por isso mesmo, era grande. A despeito do protocolo austero e formal com que os meios de comunicação oficiais tratavam visitas estrangeiras, Moscou dava todos os sinais de que atribuía uma importância excepcional à visita do presidente eleito do Brasil. Tanto a Rádio Moscou quanto os diários governamentais Izvestia e Pravda descreveram Collor como um político jovem, dinâmico e com um programa de governo que teria, para o Brasil, o mesmo significado que a perestroika para a URSS. A agência oficial Tass, por sua vez, dava informes diários sobre as etapas da viagem de Collor ${ }^{252}$. Além disso, noticiou-se, com incomum ênfase, a concessão de credenciais ao novo embaixador do Brasil em Moscou, Sebastião do Rego Barros ${ }^{253}$.

No Brasil, também havia entusiasmo com relação à visita do presidente eleito a terras soviéticas. A normalização política já vinha se construindo desde 1985, quando o então chanceler Olavo Setúbal visitou a URSS - e foi reciprocado por seu contraparte, Eduard Shevardnaze, em 1987 e, no ano seguinte, deu-se a visita oficial de Sarney a Moscou e Leningrado $^{254}$. Diplomatas e empresários brasileiros viam a necessidade de aprofundamento de relações econômicas com a União Soviética, um parceiro até então distante, mas com grandes potenciais de complementaridade. Algumas joint ventures, em setores tão diversos como suco de laranja, confecção têxtil e informática, já haviam sido estabelecidas. Falava-se, inclusive, da abertura de um escritório de representação do Banco do Estado de São Paulo (Banespa) em Moscou, tornando-se a primeira instituição financeira latino-americana a instalar-se no país ${ }^{255}$.

Além disso, uma questão pessoal tornava o encontro particularmente interessante a Collor de Mello: por algumas vezes em sua campanha, ele havia buscado criar algum tipo de

\footnotetext{
${ }^{251}$ Spinola, Noenio. "Rússia para Collor ver”. O Estado de São Paulo, 30 de janeiro de 1990, p. 2.

${ }^{252}$ FSP, "URSS espera de Collor a "perestroika brasileira"”, 31 de janeiro de 1990, p. A-8.

${ }^{253}$ FSP, “Imprensa soviética dá destaque a visita de Collor que começa hoje”, 30 de janeiro de 1990, p. A-10.

${ }^{254}$ Ver Pereira, 2003.

${ }^{255}$ FSP, “Itamaraty espera relações melhores", 30 de janeiro de 1990, p. A-10.
} 
identificação entre si próprio e Gorbachev ${ }^{256}$. Nos últimos anos, o líder soviético fora alçado, nas palavras de Sebastião do Rego Barros, à condição do superstar mundial. "Se você pegar a partir da posse do Gorbachev em [19]85, o mundo, de certa maneira, passa a viver em torno do Gorbachev" 257 . Chama a atenção, ademais, O que chamava a atenção do presidente eleito do Brasil era não só a imagem de grande reformista do fim do século, que Gorbachev havia habilidosamente construído, mas também seu engajamento veemente com a causa ambiental, à qual propunha uma "perestroika de 180 graus" 258 .

Ao desembarcar em Moscou, Collor foi recebido com honras de estadista pelo primeiro vice-presidente do Soviete Supremo, Anatoli Lukianov, e Viktor Komplektov, viceministro das Relações Exteriores. No dia 31 de janeiro, Collor reuniu-se com o premiê soviético, Mikhail Gorbachev, que elogiou o presidente eleito por ter aproveitado este momento, antes da posse, para viajar pelo mundo. "Depois não dará tempo", observou. Na conversa, ambos defenderam a necessidade de aumentar o intercâmbio comercial entre o Brasil e a União Soviética e promover maior cooperação nas áreas científica e tecnológica ${ }^{259}$. Trataram, também, de problemas ligados à América Central e ao Caribe, de interesse comum entre os dois países. Collor aproveitou para transmitir a Gorbachev uma mensagem de Bush sobre as dificuldades que o líder da URSS enfrentava no Azerbaijão - o que, segundo o chanceler Shevardnadze, criou condições para um telefonema posterior entre os presidentes americano e soviético ${ }^{260}$. A imprensa mundial deu, no dia seguinte, bastante destaque à alegada mediação russo-americana feita pelo presidente eleito do Brasil ${ }^{261}$.

O último compromisso político de Collor de Mello em Moscou foi uma cerimônia na Academia de Ciências, entidade de grande importância científico-tecnológica e política ao país $^{262}$. Em seu pronunciamento, o presidente eleito frisou a necessidade de se definir e

\footnotetext{
${ }^{256}$ FSP, "Eleito elogiou o líder soviético", 31 de janeiro de 1990, p. A-8.

${ }^{257}$ Barros, Sebastião do Rego. Sebastião do Rego Barros II. (depoimento, 2009). Rio de Janeiro: CPDOC, 2011, p. 22.

258 "Com sua extraordinária capacidade de transformar desafios em surpresas, Gorbachev associa a perestroika à ideia ambientalista. A motivação imediata residirá talvez nos dois grandes desastres ecológicos do regime soviético: o acidente de Chernobyl e a dessecação do Lago Aral. Habilmente, Gorbachev transformou a retificação de erros no apostolado de uma nova causa. Suas propostas são ousadas. Primeiro, é necessário ecologizar a política. Segundo, o direito ao meio ambiente sadio passa a ser um direito humano fundamental. Terceiro, é necessária a formulação de um código internacional de ética ecológica. Quarto, cumpre-se criar uma Cruz Verde internacional para socorrer os locais atingidos por catástrofes ecológicas, através da formação na ONU de esquadrões de capacetes verdes disponíveis para auxiliar em emergências ecológicas. Quinto, e mais controversamente, estabelecer-se-iam mecanismos de controle internacional, que permitissem inspeções em territórios de outros países para monitoramento da politica ecológica". Campos, Roberto. "Moscou revisitada". O Estado de São Paulo, 30 de janeiro de 1990, p. 2.

${ }^{259}$ OESP, "Gorbachev elogia eleições brasileiras", 01 de fevereiro de 1990, p. 5.

${ }^{260}$ O Globo, "Carta gera contato entre EUA e URSS", 02 de fevereiro de 1990, p. 3.

261 Rego Barros, 2011, p. 23.

${ }^{262}$ FSP, “Academia tem influência", 02 de fevereiro de 1990, p. A-5.
} 
explorar um novo diálogo Leste-Sul, entre os países do bloco soviético e os subdesenvolvidos. “A corrida pelo Leste não pode ser a corrida para longe da América Latina. Ao contrário, é hora de evitar divisões. Impõe-se reunir todos os países com superior necessidade de desenvolvimento acelerado num esforço conjunto de cooperação e de coordenação de interesses" ${ }^{263}$. Collor também exaltou as transformações promovidas por Gorbachev e traçou um paralelo entre as situações vividas pelos dois países:

\footnotetext{
"Feitas as ressalvas necessárias, identifico minha luta e a luta do povo brasileiro com a luta do presidente Gorbachev e do povo soviético. Talvez hoje as ideologias não tenham o valor de outras épocas, não sejam mais orientadoras rígidas da gerência da sociedade. Hoje, o fundamental é a busca, por meios eficientes e adequados, do bem-estar social" ${ }^{264}$.
}

Ainda durante a reunião, o presidente eleito abordou temas ligados à dívida externa e à ecologia - neste caso, propôs-se o estabelecimento de um acordo bilateral para o desenvolvimento de tecnologia que proteja as matas daqueles que eram considerados "os dois maiores reservatórios de oxigênio do planeta" ${ }^{265}$. Por fim, o Brasil foi convidado pelos membros da Academia de Ciências a integrar um projeto internacional para a construção de um reator termonuclear, chamado Takamak. Até então, só participavam do projeto, além da URSS, os EUA, os países europeus-ocidentais e o Japão. Para Collor, o convite foi, em si, uma importante vitória política, já que seus esforços pessoais concentravam-se em criar espaços de diálogo com interlocutores importantes no plano mundial ${ }^{266}$.

Em Bonn, próximo destino do presidente-eleito, Collor encontrou-se com o presidente alemão, Richard von Weizsaecker. Um tema, em particular, preocupava o brasileiro: o risco da debandada de investimentos da América Latina em direção ao Leste Europeu. Quanto a isso, Weizsaecker garantiu-lhe - como havia afirmado, também, ao presidente mexicano, Carlos Salinas de Gortari, que visitara a RFA dois dias antes de Collor - que não haveria risco, pois os interesses alemães nas economias latino-americanas eram de longo prazo ${ }^{267}$.

$\mathrm{Na}$ reunião que teve com o chanceler Helmut Kohl e outros ministros alemães, no dia seguinte, 3 de fevereiro, dois temas foram prioritários: dívida externa e ecologia. Após a apresentação do plano de estabilização econômica, os membros do governo alemão disseram estar entusiasmados com a possibilidade de ajudar o Brasil a encontrar uma "solução

\footnotetext{
${ }^{263}$ O Globo, "Collor propõe novo diálogo Leste-Sul”, 02 de fevereiro de 1990, p. 3.

${ }^{264}$ O Globo, "Collor propõe...".

${ }^{265}$ O Globo, “Acordo preservará Amazônia e Sibéria”, 02 de fevereiro de 1990, p. 3.

${ }^{266}$ FSP, "URSS convida Brasil a integrar projeto nuclear", 02 de fevereiro de 1990, p. A-5.

${ }^{267}$ FSP, "Presidente alemão diz que AL não será esquecida", 02 de fevereiro de 1990, p. A-6.
} 
duradoura" para o problema da dívida. No campo ambiental, Collor afirmou que "todos esses efeitos da poluição são ocasionados pelos países industrializados", condenando o gasto excessivo das potências com armamentos e que o total gasto, US\$ 800 milhões, poderia ser utilizado para "limpar nosso planeta em cinco anos". As palavras do presidente-eleito repercutiram positivamente, sobretudo entre os membros do Partido Verde alemão, interessados em assegurar o enfoque ambiental da política externa alemã ${ }^{268}$. No encontro que manteve com empresários e banqueiros, Collor agradou a seus interlocutores ao apresentarlhes suas ideias sobre a modernização do país, dívida externa e ecologia ${ }^{269}$. Naquela oportunidade, Collor chamou os carros nacionais de "verdadeiras carroças", declaração que ficaria marcada como um símbolo da necessidade da abertura do mercado automobilístico para a concorrência estrangeira ${ }^{270}$.

Em Berlim e Turim, Collor fez um roteiro de promoção pessoal, sem qualquer tipo de agenda política. Na primeira cidade, símbolo do fim da Guerra Fria, a ideia era somente ser visto próximo ao muro de Berlim já em pedaços, mas a viagem acabou sendo prejudicada por hostilidades de brasileiros que se manifestaram contra sua presença. Na cidade italiana, sede dos jogos da primeira fase da seleção brasileira na Copa de 1990, o presidente-eleito aproveitou a visita para reunir-se com o empresário Giovanni Agnelli, presidente da Fiat e de um conglomerado de mais de 500 empresas, considerado um dos maiores industriais da Itália $^{271}$. Em Roma, Collor participou de seis reuniões - inclusive com o primeiro-ministro, Giulio Andreotti e com o presidente, Francesco Cossiga -, todas de caráter protocolar.

Em Paris, no dia 6 de fevereiro, Collor encontrou-se com François Mitterrand. A conversa foi pautada pela questão da dívida externa e envolveu grandes comitivas de ambos os lados, em contraste com outras reuniões com autoridades, às quais não foi dada tanta importância substantiva. Embora não se tenha falado em ecologia - tema caro às relações bilaterais Brasil-França, em função de acontecimentos recentes -, a abordagem da temática da dívida, em si, pode ser considerada um grande êxito político. Collor recebeu a "forte solidariedade" de Mitterrand na negociação entre o futuro governo e o Clube de Paris, conseguindo apoio à sua tese de que o pagamento dos juros somente seria reiniciado depois de asseguradas condições para o desenvolvimento econômico do país ${ }^{272}$. Aos empresários

\footnotetext{
${ }^{268}$ Cf. Lohbauer, Christian. Brasil-Alemanha: fases de uma parceria 1964-1999. São Paulo: KAS/EDUSP, 2000.

${ }^{269}$ FSP, "Collor repete sucesso em reunião com empresários", 03 de fevereiro de 1990, p. A-7.

${ }^{270}$ OESP, "Comparação entre carro e carroça cria polêmica", 11 de fevereiro de 1990, p. 12.

${ }^{271}$ FSP, "Collor visita em Turim estádio da Copa do Mundo", 4 de fevereiro de 1990, p. A-6.

${ }^{272}$ FSP, "Mitterrand oferece apoio na negociação da dívida", 7 de fevereiro de 1990, p. A-5.
} 
franceses, o presidente-eleito causou boa impressão ao falar de suas reformas liberalizantes ${ }^{273}$. Com o primeiro-ministro Rocard, que já havia recebido Collor ainda candidato, no ano anterior, o tema ambiental voltou à pauta, lado a lado com a questão da dívida. De acordo com o assessor de imprensa do presidente-eleito, Rosa e Silva, embora a viagem não tivesse o intuito de fechar acordos, havia a decisão concreta, por parte do governo brasileiro, de "renegociar a dívida em termos que assegure (sic) a soberania nacional"274.

Em Londres, Collor reuniu-se com a primeira-ministra, Margaret Thatcher, com o príncipe Charles e com representantes dos bancos britânicos. Destes, recebeu o compromisso de que iriam retirar as pré-condições para a negociação da dívida com o Brasil - num voto de confiança às reformas modernizantes prometidas pelo presidente-eleito. Os banqueiros afirmaram que o primeiro passo para as conversas entre o governo brasileiro e os credores londrinos já havia sido dado quanto Collor afirmou que não entraria em confronto com a comunidade financeira internacional $^{275}$.

O momento mais difícil do presidente-eleito foi em Portugal. Collor gastou a maior parte de seu tempo buscando apagar a "péssima repercussão" que havia causado uma piada contada por ele a Carlos Menem, algumas semanas antes ${ }^{276}$. Nos encontros que manteve com Mário Soares e Cavaco Silva, o tema principal foi o comércio bilateral, com destaque para a operação de um crescente número de empresas brasileiras em terras lusitanas. A ideia do novo presidente era valer-se de Portugal como porta de entrada aos produtos brasileiros no continente europeu, a partir de $1992^{277}$. O crescente interesse mútuo justificou, após a passagem de Collor por Lisboa, o estabelecimento de uma "linha direta" entre Collor e o presidente Soares, bem como a manutenção de iniciativas lançadas pelo governo Sarney, como o Instituto Internacional da Língua Portuguesa ${ }^{278}$

A última etapa do périplo do presidente-eleito foi a Espanha. Os jornais destacaram a sintonia pessoal entre Collor e o primeiro-ministro espanhol, Felipe González, político de características muito semelhantes às do brasileiro - seja pela juventude, pelas alegadas

\footnotetext{
${ }^{273}$ FSP, "França estuda criação de fundo de investimento", 7 de fevereiro de 1990, p. A-6.

${ }^{274}$ FSP, "Collor discute dívida e ecologia com Rocard", 8 de fevereiro de 1990, p. A-4.

${ }^{275}$ FSP, "Collor obtém promessa de banqueiros britânicos", 9 de fevereiro de 1990, p. A-6.

${ }^{276}$ Ganhou ampla repercussão uma anedota contada por Collor a Menem, diante de jornalistas. Segundo o presidente eleito, seu maior concorrente nas eleições, Luiz Inácio Lula da Silva, ganhara popularidade em alguns países europeus, levando certas pessoas a imitar o estilo de Lula. Enquanto os franceses resolveram usar seu boné e os alemães deixaram crescer a barba, os portugueses resolveram cortar o dedo mínimo da mão esquerda. Transmitida a Lisboa por meio de agências internacionais de notícias, a piada chegou a provocar uma manchete indignada num dos maiores jornais do país, o Diário de Lisboa, que publicou reportagem intitulada "Collor insulta os portugueses". Ver Veja, "Perfil do presidente", 31 de janeiro de 1990, p. 36

${ }^{277}$ FSP, "Comércio domina conversa", 10 de fevereiro de 1990, p. A-7.

${ }^{278}$ FSP, "Soares vai manter consultas com Collor", 11 de fevereiro de 1990, p. A-8.
} 
convicções políticas, ou pelo estilo de vida ${ }^{279}$. De González, o presidente-eleito ouviu uma advertência: independentemente do Leste Europeu - fonte dos maiores temores do novo governo brasileiro, por representar um polo concorrente de atração de investimentos e comércio - caberia ao Brasil demonstrar à comunidade internacional "confiabilidade e credibilidade". Sem o reordenamento da economia, que se encontrava em aguda crise, não haveria possibilidade de ingressos expressivos de capital no país ${ }^{280}$.

Em balanço da viagem, o porta-voz do presidente-eleito, Cláudio Humberto Rosa e Silva, disse que Collor quer integrar o Brasil aos países do Primeiro Mundo. "Não interessa ao Brasil a posição de líder dos miseráveis. O presidente deseja inverter o processo estabelecido nos últimos anos por José Sarney, a opção de ser grande entre as nações subdesenvolvidas" 281 . Esse mesmo mote - o Brasil como último dos primeiros e não como primeiro dos últimos seria repetido por Collor em algumas oportunidades posteriores ${ }^{282}$. Exatamente por esse tipo de retórica, além da boa impressão pessoal que causou à maioria de seus interlocutores, o balanço da viagem de presidente-eleito foi bastante positivo. De acordo com editorial da Folha de São Paulo,

\begin{abstract}
"o presidente eleito apresentou, às principais autoridades econômicas e políticas do mundo desenvolvido, propósitos de integração efetiva do Brasil no cenário internacional; transmitiu para o público interno e externo, com incansável talento de marketing, a imagem de modernização e dinamismo que pretende atribuir a seu governo (...). É na prática de governo, contudo, que se irá comprovar ou não a consistência dos projetos do presidente eleito. Enunciou-os, apenas; mas é inegável que o fez com bastante talento".
\end{abstract}

As incertezas que permaneciam estavam ligadas à capacidade de Collor de realmente efetivar as promessas realizadas além-mar ${ }^{283}$. O primeiro passo no sentido de concretizar as promessas era montar uma equipe de governo compatível com seus objetivos políticos, e foi a isso que o presidente eleito se dedicou nos dias que se seguiram.

\title{
3.3. A definição do novo governo ${ }^{284}$
}

De volta ao Brasil, coube a Collor definir os nomes de seu governo no mês que lhe restava até a posse. O nome de Zélia Cardoso de Mello como ministra da Economia

\footnotetext{
${ }^{279}$ FSP, "Primeiro-ministro espanhol também cultua a aparência", 11 de fevereiro de 1990, p. A-7.

${ }^{280}$ FSP, "Brasil tem de mostrar confiabilidade, diz González", 11 de fevereiro de 1990, p. A-8.

${ }^{281}$ FSP, "Collor quer Brasil no Primeiro Mundo, diz assessor", 12 de fevereiro de 1990, p. A-5.

${ }^{282}$ NYT, "Brazil aspires to Big League in More than Soccer", 9 de fevereiro de 1990.

${ }^{283}$ FSP, "Europa gosta de discurso, mas prefere esperar", 18 de fevereiro de 1990.

${ }^{284}$ Parte desta seção foi adaptada de Casarões, 2012.
} 
(superministério que acumularia as funções da Fazenda, Planejamento e Indústria e Comércio) foi anunciado no dia $1^{\circ}$ de março, causando reações positivas entre empresários e opinião pública $^{285}$. Para espectadores externos, a nomeação de Zélia - assessora de Collor desde o início da campanha e caracterizada por sua lealdade ao presidente-eleito - era sinal de que o governo cumpriria as promessas a partir das propostas apresentadas nas viagens ao exterior. A partir daí, a composição da equipe vinculada à política externa tornava-se questão menos central - uma vez que os contenciosos mais graves eram de natureza financeira e comercial.

De todo modo, para um presidente-eleito sem lastro partidário ou equipe consolidada, era necessário transmitir uma mensagem de credibilidade - para consumo interno e para fora. Não nos parece trivial, portanto, a decisão de se cercar de diplomatas de carreira. No tocante à substância de sua agenda de política externa, Collor já vinha dando ouvidos a alguns "filhos de Rio Branco", a começar por seu próprio cunhado, o embaixador Marcos Coimbra, que já o vinha assessorando desde a campanha. Nomeado chefe do Gabinete Civil do Palácio do Planalto, em 31 de janeiro, Coimbra firmou-se como "o mais próximo e poderoso colaborador do presidente eleito" com a indicação ao gabinete, cargo que perderia status de ministério - e, portanto, contornos mais políticos - com a reforma administrativa proposta pelo novo governo, mas que ganharia, por outro lado, uma posição de aconselhamento e assessoramento direto ao presidente.

A experiência internacional de Coimbra era vasta. O embaixador já havia servido em Portugal, Paraguai, Itália, Turquia, Romênia, África do Sul, Costa do Marfim, Canadá, Egito, Japão, Grécia e $\mathrm{Cuba}^{286}$. O fato de não ter circulado nas embaixadas mais prestigiadas de Paris, Londres e Roma - o chamado circuito "Elizabeth Arden" - dava à carreira de Coimbra certa aura de "independência", uma das razões pelas quais o presidente eleito o havia escolhido para assessorá-lo. "Collor o respeita tanto que nas reuniões da assessoria pede silêncio quando o embaixador vai falar", reporta uma matéria da Veja ${ }^{287}$. Além do contato permanente com Collor, o que era privilégio de poucos a seu redor, o embaixador também funcionava como a porta de acesso ao presidente eleito: a maioria das figuras recebidas por Collor passavam primeiro pelo gabinete do embaixador. Havia sido Coimbra, aliás, a optar pelo "bolo de noiva" do MRE como sede da transição do governo.

\footnotetext{
${ }^{285}$ FSP, "Collor anuncia Zélia ministra da Economia", $1^{\circ}$ de março de 1990, p. A-5.

${ }^{286} \mathrm{Na}$ embaixada de Havana, atuando como segundo secretário e encarregado de negócios, esteve nos três primeiros anos da revolução cubana, entre 1959 e 1961. Atribui-se aos laços de Coimbra com Fidel Castro a disposição do líder cubano em comparecer à cerimônia de posse de Collor, que ocorreria pouco tempo depois. JB, "Collor escolhe Coimbra para o seu Gabinete Civil", 31 de janeiro de 1990, p. 3

${ }^{287}$ Veja, "O homem dos segredos", 31 de janeiro de 1990, p. 34.
} 
Outra figura importante na composição do governo foi o diplomata Gelson Fonseca Jr., ministro de segunda classe do Itamaraty e ex-chefe de gabinete do Secretário-Geral do MRE no governo Sarney, Paulo Tarso Flecha de Lima. O primeiro contato entre Collor e Fonseca Jr. deu-se ainda em campanha, por meio de briefings sobre política externa que os candidatos faziam com Flecha de Lima, dos quais participava. Após a eleição, Marcos Coimbra, já encarregado da transição de governo, convida o ministro Gelson para organizar as viagens de presidente-eleito e acompanhar Collor em seu tempo no exterior. Com a definição da equipe, Fonseca Jr. tornou-se, em caráter oficial, assessor presidencial para assuntos internacionais, incumbido de compatibilizar as ideias de Collor aos quadros conceituais da diplomacia brasileira - redigindo os discursos das viagens internacionais, bem como discurso de posse do presidente, cuja autoria dividiu com outro diplomata, o embaixador José Guilherme Merquior ${ }^{288}$.

Merquior também exerceu importante influência ideológica sobre Collor - menos como diplomata e mais como pensador liberal que era ${ }^{289}$. O ex-presidente relata que a primeira conversa que teve com Merquior, em que foram tratadas questões ideológicas e programáticas, foi na viagem que fez a Paris (onde servia o diplomata, na qualidade de Representante Permanente do Brasil junto à UNESCO) em fevereiro. Durante a troca de ideias, Merquior teria classificado Collor como "social-liberal", em função das visões de mundo que havia apresentado durante a campanha e até cogitaram, dada a afinidade de ideias, lançar um partido político juntos ${ }^{290}$. Inicialmente cotado para a chancelaria, Merquior acabou sendo sondado para ocupar o Ministério da Cultura, às vésperas da posse, mas não aceitou. Contribuiu, de todo modo, com a formulação conceitual do discurso de posse e, a despeito da morte prematura em 1991, viria a ressurgir no contexto do governo Collor quando o presidente, já no início de 1992, buscou lançar os conceitos que Merquior havia formulado

\footnotetext{
288 “O Merquior fez o discurso. Mas faltava a parte de política externa, e eu, então, acrescentei. Esse discurso tem uma coisa engraçada. O Roberto Campos, nas memórias dele, menciona esse discurso e diz: o Collor fez um bom discurso, mas a parte de política externa é muito ruim; e foi feita por um diplomata, que era aquele barbudinho... Que ele me identificava, não sei por que, com o Silveira. Então disse que o discurso era uma mistura de London School com Patrice Lumumba. [risos] Tinha o Merchior, que era a London School e tinha eu, que era a Universidade Patrice Lumumba". Fonseca Jr., Gelson. Gelson Fonseca Junior (depoimento, 2008). Rio de Janeiro, CPDOC, 2011.

${ }^{289}$ Entre as obras filosóficas de Merquior, destacam-se Merquior, José Guilherme. O Argumento Liberal. Rio de Janeiro: Nova Fronteira, 1983;

of Latin American Research, vol. 6, no. 2, 1987b; "Brazil's New Republic: the Social-Liberal Path". Bulletin de Janeiro: Nova Fronteira, 1991. De acordo com Ricupero, “O Zé Guilherme deu ao Collor um embasamento doutrinário e filosófico que faltava a ele (...). Procurou mostrar que o liberalismo poderia ser político, avançado e progressista - coisa que, depois de sua morte, nenhum outro pensador brasileiro conseguiu fazer". Ricupero, Rubens. Entrevista ao autor. São Paulo, 30 de outubro de 2014.

290 "Falamos até na formação de um partido, que seria o PSOL [Partido Social Liberal], era o partido que iríamos montar. Depois a Heloísa Helena pegou a sigla...” Entrevista concedida ao autor em 13 de junho de 2011.
} 
como seus próprios, sem dar-lhe o devido crédito.

Como já vimos, o embaixador brasileiro no GATT, Rubens Ricupero, também influenciou diretamente o pensamento de Collor, ainda candidato. Seu nome - que havia aparecido em agosto, em nota da Folha de São Paulo, como o favorito do ex-governador alagoano para assumir a pasta, se fosse eleito - volta a aparecer nas primeiras listagens de "ministeriáveis", lançadas pelos jornais após a eleição. O único senão de Ricupero era sua proximidade com o governo Sarney, a cujo presidente servira como assessor diplomático, logo após o falecimento de Tancredo Neves. Ademais, contribui para a impressão de que havia certa afinidade entre Ricupero e Collor uma entrevista dada pelo embaixador ao Estado de São Paulo, ainda em agosto de 1989, em que faz menção nominal a Collor e a seu favoritismo nas pesquisas eleitorais "justamente por representar o anseio da sociedade brasileira por uma regeneração total". O tom com que conclui a entrevista também é revelador:

\footnotetext{
"Estamos precisando de valores novos. O político que descobrir que a estabilidade é o desejo maior do brasileiro entrará para a História, como fez Campos Salles, ao recuperar o valor de nossa moeda, na República Velha. Como gosta de dizer o embaixador Marcílio Marques Moreira, quem não tem moeda não tem soberania. $\mathrm{O}$ Brasil precisa recuperar sua moeda. Aí, sim, reaverá sua soberania"291.
}

Com a oficialização de Coimbra na coordenação da candidatura, contudo, a aproximação com o embaixador brasileiro no GATT foi postergada. Questionado sobre seu futuro posto na administração federal logo após o resultado das eleições, Ricupero disse nutrir uma expectativa "positiva e simpática" sobre o novo governo ${ }^{292}$, embora não tivesse "sinal algum" de que seria convidado para a chancelaria ${ }^{293}$.

Por fim, outro nome cotado para assumir a chancelaria era o de Álvaro da Costa Franco Filho, embaixador em Bogotá 294 . O embaixador Costa Franco havia circulado por Paris e Washington na década de 1970, assumindo a chefia do gabinete do Gabinete Civil da Presidência durante o governo Figueiredo, entre 1981 e 1984. Passou quase um ano como encarregado de delegação permanente do Brasil junto à UNESCO, em Paris, antes de assumir a embaixada em Bogotá, em dezembro de $1985^{295}$. Tratava-se de cargo importante, pois o governo brasileiro possuía interesses diversos na Colômbia, coordenando interesses bilaterais

\footnotetext{
${ }^{291}$ OESP, "O Brasil precisa de uma perestroika”, 27 de agosto de 1989, p. 84.

292 OESP, "Ricupero nega convite do PRN", 22 de dezembro de 1989, p. 6.

${ }^{293}$ FSP, "Ministro da Economia deve ter o perfil de Ermírio", 19 de dezembro de 1989, p. B-3.

${ }^{294}$ FSP, 17 de janeiro de 1990, p. A-4.

${ }^{295}$ Curriculum Vitae do Servidor Álvaro da Costa Franco Filho, disponível nos arquivos do Ministério das Relações Exteriores. Acesso em agosto de 2014.
} 
em múltiplos níveis: do café ${ }^{296}$ à dívida externa (cujas discussões articulavam-se politicamente por meio do Consenso de Cartagena), das concertações políticas de ajuda aos vizinhos centro-americanos (grupos de Contadora e Apoio a Contadora) às tensões regionais $^{297}$. A Colômbia também seria parceira importante nos esforços de integração latinoamericana do governo Collor, aspecto que vinha sendo enfatizado desde o início da campanha presidencial. Além disso, lembra Ricupero, Costa Franco "era considerado, entre os diplomatas mais conservadores - que não eram ligados à linha da política externa independente - talvez o de maior renome (...). Intelectualmente, era o mais respeitado dos conservadores e relativamente próximos ao regime militar" ${ }^{298}$.

O nome do chanceler do governo Collor foi mantido em segredo até poucos dias antes da posse. Com as especulações em torno de nomes para ministérios mais críticos, que canalizaram o debate público sobre a composição do novo gabinete, os potenciais indicados para o Itamaraty apareciam de maneira esparsa nos noticiários. Pode-se aventar a hipótese de que, passada a euforia da eleição, Collor preferiu ganhar tempo para elaborar, ele próprio, uma agenda de política externa que fosse apresentada ao mundo como "autoral". Isso joga luz sobre a decisão de manter Coimbra como um assessor mais geral, sem necessariamente vinculá-lo à política externa ${ }^{299}$.

De todo modo, o fato de serem diplomatas de carreira os mais prováveis chanceleres ${ }^{300}$ rompia, em algum sentido, com as nomeações de caráter político do governo Sarney, que havia concedido o cargo, respectivamente, a Olavo Setúbal e a Roberto de Abreu Sodré, ambos filiados ao PFL. Por isso mesmo, surpreendeu a escolha, a dois dias da posse, do então ministro do Supremo Tribunal Federal - e presidente do Tribunal Superior Eleitoral durante as eleições presidenciais - José Francisco Rezek. A justificativa do presidente-eleito, transmitida pelo seu porta-voz, é que Collor nutria por Rezek "enorme admiração"301 . Não tardou, contudo, para que surgissem críticas à escolha, não pelas qualidades do jurista em si, mas pelas suspeições que ela levantava, dadas certas polêmicas do processo eleitoral que podem ter favorecido o presidente-eleito. Brizola foi um dos primeiros a reagir, chamando a

\footnotetext{
${ }^{296} \mathrm{O}$ Instituto Brasileiro do Café passava por uma crise financeira e havia, recentemente, enxugado seus escritórios ao redor do mundo, deixando os de Nova York e Bogotá.

${ }^{297}$ A Colômbia viveu um sangrento episódio em novembro de 1985, que ficou conhecido como a Tomada do Palácio de Justiça. Um comando de guerrilheiros do Movimento 19 de Abril (M-19) invadiu o Palácio do Judiciário colombiano, tomando centenas de reféns e levando a uma intervenção do Exército Nacional. O saldo, depois de um dia de combate, foi de 98 mortos. Ver http://www.semana.com/wf_InfoArticulo.aspx?idArt=82348 ${ }^{298}$ Rubens Ricupero, entrevista ao autor, 30 de outubro de 2014.

${ }^{299}$ FSP, “Collor define a $1^{\text {a }}$ viagem", 28 de dezembro de 1989, p. A-4.

${ }^{300} \mathrm{O}$ então senador Fernando Henrique Cardoso foi sondado para assumir a pasta, mas o acordo foi vetado pelas lideranças de seu partido, o PSDB.

${ }^{301}$ FSP, "Collor indica presidente do TSE para Itamaraty", 13 de março de 1990, p. 1.
} 
nomeação de Rezek "um fato insólito". Em sua coluna, Gilberto Dimenstein elabora a crítica em cima da reação do político do PDT:

\begin{abstract}
"Não se coloca em dúvida a integridade de Rezek nem as intenções de Collor em convidá-lo. Mas é inevitável que tal escolha provoque insinuações como as de Brizola (...). Rezek julgou questões de interesse direto de Collor de Mello, certamente baseado nos mais límpidos princípios jurídicos. Algumas dessas questões, entretanto, interessavam diretamente ao presidente eleito, como, por exemplo, a elegibilidade do empresário Silvio Santos, na qual Rezek fez questão de votar contra"302
\end{abstract}

O próprio ex-chanceler nega as suspeitas, embora compreenda as críticas realizadas à época. Garante que Collor, pela ausência de lastro partidário, precisou recorrer a nomes de boa reputação pública para compor sua equipe: "assim foi com o [Secretário de Ciência e Tecnologia] Goldemberg, assim foi com o [Secretário do Meio Ambiente] Lutzenberger, assim foi com o [Ministro da Infra-Estrutura] Ozires Silva, assim foi comigo... e, veja, a ideia era essa, ele tinha a intenção de governar, de fazer um bom governo e de redimir, enfim, aquilo que ainda restava de negativo na imagem brasileira",303.

De fato, a reputação de Rezek é uma boa hipótese para explicar sua nomeação à chancelaria. Além de sua trajetória como jurista e intelectual, em janeiro de 1990, o ministro havia ganhado o prêmio de Personality of the Year pela Associação dos Correspondentes da Imprensa Estrangeira. Poderia passar credibilidade para o público doméstico e internacional. Soma-se a isso o fato de que o nome de Rezek repercutiu bem no Itamaraty de imediato, uma vez que o novo ministro não pertencia a "grupos de influência de diplomatas"304. Mesmo não sendo considerado alguém com plena identificação com a Casa de Rio Branco, como lembra Celso Amorim ${ }^{305}$, o fato de ter sido professor do Instituto Rio Branco por uma década o credenciava como alguém a quem os diplomatas poderiam ter como aliado.

Outras duas hipóteses ligam-se a questões internas ao Ministério das Relações Exteriores. A primeira delas está relacionada a um problema interno pelo qual vinha passando o Itamaraty, ligado a denúncias de corrupção em um de seus órgãos, a Fundação Visconde de Cabo Frio. Desvios de verbas foram revelados - e, mais tarde, comprovados - pelo jornalista Gilberto Dimenstein, da Folha de São Paulo, deflagrando uma crise institucional que se arrastou ao longo do segundo semestre de $1989^{306}$. É possível - e não passa de suposição -

\footnotetext{
${ }^{302}$ Dimenstein, Gilberto. “A honra de Rezek”. Folha de São Paulo, 14 de março de 1990, p. A-2.

${ }^{303}$ Rezek, Francisco. Entrevista ao autor, 19 de maio de 2011.

${ }^{304}$ O Globo, "Escolha repercute bem no Itamaraty", 13 de março de 1990, p. 3.

305 Amorim, 1997.

${ }^{306}$ Dimenstein, Gilberto. Conexão Cabo Frio: escândalo no Itamaraty. São Paulo: Brasiliense, 1989.
} 
que Collor não quisesse dar muita autonomia a uma burocracia recentemente maculada por um escândalo de corrupção, até porque isso convergia com dois aspectos de sua própria trajetória recente: a alegada intolerância contra improbidades, por um lado, e o veio centralizador, por outro. Não surpreenderia se Collor, que já havia declarado querer ser seu próprio ministro da Economia, também quisesse ser seu próprio chanceler.

A segunda hipótese, vinculada à primeira, diz respeito a uma série de reformas que o presidente quis empreender no Itamaraty. Entre considerações - muitas não-cumpridas - de fechar e reestruturar embaixadas e postos no exterior, duas mudanças ficaram marcadas como o ponto negativo da relação de Collor com o Itamaraty: a famigerada "tripartição" da Secretaria-Geral do MRE e a mudança nas regras da carreira, com o estabelecimento da “expulsória". Pelo impacto que causaram, elas dificilmente teriam sido levadas a cabo por um diplomata de carreira ${ }^{307}$ à frente da chancelaria, o que reforça a nomeação de alguém de fora do corpo diplomático. Havia, além disso, um aspecto de caráter pessoal: o principal envolvido no "escândalo Cabo Frio" era Paulo Tarso Flecha de Lima, considerado o chanceler de fato do governo Sarney.

Era necessário limitar os poderes de um super Secretário-Geral. Essa impressão é compartilhada pelo embaixador Luiz Felipe Lampreia:

\footnotetext{
"E o Marcos Coimbra tinha como grande amigo no Itamaraty o embaixador Eduardo Hosana ( sic) (...), que tinha a obsessão de fazer com que houvesse uma mudança na estrutura da carreira. E ele criou então (...) um esquema anti Paulo Tarso. A (...) obsessão era... dos dois, tanto do Marcos Coimbra quanto do Hosana, não é? Então eles partiram a Secretaria-Geral em três" ${ }^{308}$
}

Rememorando o processo de mudança institucional, o ex-chanceler Rezek também subscreve a essa ideia, dizendo que foi concebida antes mesmo do início do governo:

\begin{abstract}
"E tem sim a ver com o Paulo Tarso Flecha de Lima e ao tempo do Chanceler Abreu Sodré, a grande eminência, o grande poder de mando do Paulo Tarso. Agora de fato ele tinha um sentido de absorção de poder que era incrível (...), é assim, ele gosta de participar de tudo! É uma absorção de poder em sentido horizontal e vertical. E isso fez dele (...) um dos dínamos mais impressionantes da diplomacia brasileira. E não há dúvidas, por ele também, digamos, o núcleo familiar do Presidente Collor não morria de amores"309
\end{abstract}

Com efeito, o Decreto $\mathrm{n}^{\circ}$ 99.261, de 23 de maio de 1990, instituía três diferentes Secretarias-Gerais: a de Política Exterior, responsável por todos os Departamentos e suas

\footnotetext{
${ }^{307} \mathrm{O}$ que foi confirmado, em entrevista ao autor, pelo embaixador Ricupero.

${ }^{308}$ Lampreia, 2010, p. 117.

${ }^{309}$ Entrevista concedida ao autor, São Paulo, 04 de maio de 2011
} 
respectivas Divisões, relacionados às áreas de política bilateral e multilateral, econômica, de promoção comercial e cooperação tecnológica, entre outras; a Secretaria-Geral Executiva, incumbida das questões administrativas da Casa, sob a qual também estava o Instituto Rio Branco; a Secretaria-Geral de Controle, à qual couberam todas as atribuições relacionadas à administração financeira, contabilidade e auditorias. Os três Secretários-Gerais, embaixadores Marcos Castrioto de Azambuja (SGPE), Eduardo Moreira Hosannah (SGE) e Sérgio de Queiroz Duarte (SGC), despachavam com o chanceler ${ }^{310}$.

A publicação do Decreto $\mathrm{n}^{\circ}$ 99.578, de 10 de outubro de 1990, consolidou as mudanças administrativas iniciais da gestão de Francisco Rezek. Pela primeira vez, um decreto presidencial dispunha sobre a estrutura do MRE até o nível de Departamento. A nova legislação criava o Departamento de Meio Ambiente (DMA), ao qual se vincularam a Divisão de Meio Ambiente (DEMA) e a Divisão do Mar, Antártica e do Espaço (DMAE). Castro e Castro anotam que essas transformações denotavam um esforço do Itamaraty em adaptar-se às transformações da agenda internacional, com a inclusão de novos assuntos, outrora secundários, como o meio-ambiente ou a integração regional ${ }^{311}$.

$\mathrm{Na}$ esteira das reformas institucionais, houve também uma alteração significativa nas regras da carreira, a chamada “expulsória”. De acordo com a nova regra (já utilizada nas Forças Armadas), embaixadores ou ministros, após 15 anos na mesma categoria funcional, sofreriam uma espécie de aposentadoria compulsória, a partir da qual comporiam um "quadro especial" até a aposentadoria efetiva, aos setenta anos de idade. De acordo com Manuel Mendes, tratava-se de uma "forma esdrúxula de aposentadoria (...), um curioso sistema de administração de pessoal que não existe em nenhum outro serviço diplomático do mundo. Os diplomatas nesta situação não exercem função alguma, nem no Brasil nem no exterior, embora estejam em serviço ativo", passando a integrar o quadro especial, "que alguns chamam, com sarcástico realismo, de limbo"312.

Por se tratar de uma norma muito específica da carreira, a "expulsória" não é frequentemente trazida à tona no rol de mudanças institucionais, embora os diplomatas de carreira se ressintam abertamente dela. Em depoimento ao CPDOC, o embaixador Luiz Felipe Lampreia faz menção a ela, tratando-se de uma "regra nova e terrível"313. Sebastião do Rego Barros, em depoimento semelhante, considera a nova legislação “[u]ma bobageira. E a coisa

\footnotetext{
${ }^{310}$ Castro e Castro, 2009, p. 121.

311 Idem, p. 125.

${ }^{312}$ Mendes, 1995, p. 128-9

${ }^{313}$ Lampreia, 2010, p. 117.
} 
muito malfeita. Não é nada respeitável” ${ }^{\text {314 }}$. Outro diplomata, próximo ao presidente Collor, alega que, caso a regra tivesse permanecido, "mudaria muito a dinâmica da Casa",315.

Há grande controvérsia, igualmente, no que se refere à tripartição do Itamaraty. Nas palavras de Celso Lafer, ao assumir a chancelaria, em maio de 1992, “o Itamarati (sic) estava, ponto de vista interno, afetado por uma reforma administrativa, conduzida no primeiro momento do governo Collor por João Santana, que causou muita polêmica e muito desastre" ${ }^{316}$. Por outro lado, o próprio Secretário da Administração Federal do governo Collor, João Santana, alega que as mudanças institucionais inscreviam-se em um amplo "projeto de nova arquitetura organizacional para a administração pública federal”, da qual o próprio presidente-eleito participou "nas etapas definitivas". Nesse contexto, a criação de três Secretarias-Gerais tinha como objetivo desconcentrar decisões políticas e administrativas das mãos de uma só figura, de forma a evitar "a personificação da administração pública, o que é inconveniente ao seu bom funcionamento". O ex-secretário resume a ideia da seguinte maneira:

\begin{abstract}
"A reforma da estrutura organizacional do Ministério das Relações Exteriores, o Itamaraty, foi mais ampla do que a simples 'tripartição' da Secretaria-Geral, aliás nomenclatura adotada anteriormente pela antiga estrutura e abolida na reforma, quando foram constituídas as secretarias executivas, contou com a alocação de outras estruturas e o aumento dos cargos de assessoramento superior, os DASs. Em verdade em nossa concepção, não é correta a concentração político-administrativa em uma só estrutura, que além de ser responsável por exemplo pela administração geral, compras gastos etc., também o era pela formulação da política externa, ou ao menos pelo seu encaminhamento, além da coordenação funcional interna do ministério e a das várias representações externas, embaixadas, consulados"317
\end{abstract}

Em todo caso, deve-se notar que poucas mudanças institucionais são tão unanimemente condenadas como foi a tripartição da Secretaria-Geral. Celso Amorim, em depoimento ao CPDOC, sintetiza: "Aquilo foi um grande erro que depois se consertou. Aliás, ainda no governo Collor, porque o próprio ministro Resek (sic) viu que era impossível operar daquela forma" ${ }^{\natural 18}$. A impressão de Amorim é confirmada por Rezek, que acrescenta o fato de que havia atritos constantes entre os Secretários-Gerais, gerando problemas dentro da própria estrutura: "Mas o embaixador Hosannah, da Administração, e o Marcos Azambuja, volta e

\footnotetext{
${ }^{314}$ Barros, 2011, p. 25.

${ }^{315}$ Entrevista concedida ao autor, Brasília, 19 de maio de 2011.

${ }^{316}$ Lafer, 1993, p. 274.

${ }^{317}$ Entrevista concedida ao autor por e-mail, 04 de maio de 2011.

318 Amorim, 2003, p. 18.
} 
meia eu tinha que apartá-los. Não é uma boa coisa, três vice-ministros"319. Por fim, o próprio ex-presidente faz o seu mea culpa a respeito daquela mudança institucional:

"Foi um erro. foi um erro. Não deveria ter feito isso. Eu fiz isso inspirado pelo Marcos Coimbra, que advogava exatamente essa questão de secretaria geral era a super-secretaria. Mas isso criou muita confusão. Porque são carreiras de estado, que para se mexer nisso, são carreiras centenárias... E as coisas caminham dentro daquele padrão, não adianta você querer reinventar as coisas. então aquilo foi um equívoco"320.

Devemos dizer, brevemente, o que essas mudanças significaram no momento e nas circunstâncias em que elas foram implementadas. Pode-se observar, pelos depoimentos e pela argumentação exposta acima, que várias alterações foram realizadas sem muita certeza dos efeitos que causaria - redundando em equívocos - mas inspiradas, de alguma forma, pelo desejo de promover uma inflexão ideológica que alinhasse o Itamaraty às visões de mundo advogadas pelo novo governo. Ao contrário do que reza a lenda, a diplomacia não foi marginalizada, mas reconfigurada - dentro dos limites de intervenção do presidente sobre uma estrutura burocrática bastante fechada. Por outro lado, as mudanças propostas por Collor, porquanto limitadas, não causaram, nem de longe, um abalo sísmico no seio do serviço diplomático. E a política externa do período, como se quer sugerir, representou uma síntese entre o desejo de modernização, de abertura econômica, e a busca pela autonomia de inserção internacional, fio condutor do Itamaraty e uma de suas mais importantes tradições.

\footnotetext{
${ }^{319}$ Collor de Mello, entrevista ao autor, 13 de junho de 2011.

${ }^{320}$ Entrevista ao autor, Brasília, 13 de junho de 2011.
} 


\section{CAPITULO 4}

\section{Modernização na retórica, autonomia na prática}

\subsection{O discurso de posse e o sentido das relações internacionais do Brasil}

Com o primeiro escalão definido e as linhas-mestras da inserção internacional do Brasil já delineadas, a posse do presidente Collor de Mello, no dia 15 de março de 1990, veio formalizar a política externa do novo governo. Sob o título O Projeto de Reconstrução Nacional, o discurso do novo mandatário - o mais longo e propositivo da história republicana $^{321}$ - construiu-se a partir da ideia de que o Brasil se renovava e, com isso, deveria passar a ocupar um novo lugar no mundo. A renovação brasileira ocorria, em primeiro lugar, no plano das liberdades democráticas. Por isso mesmo, Collor falava em "compromisso inalterável" com a democracia, princípio que conectava passado e futuro: havia, por um lado, a recuperação do "melhor de nossa tradição de direito, liberdade e justiça"; por outro lado, o aprofundamento democrático colocava o Brasil "na vanguarda de um processo histórico de escala inédita”. Comprava-se a tese do fim da história, de Francis Fukuyama, enunciada nas páginas da revista The National Interest do ano anterior e que sustentava o seguinte:

\footnotetext{
“O que talvez estejamos testemunhando não é somente o fim da Guerra Fria, ou o ocaso de um período específico da história do pós-guerra, mas o fim da história como tal: isto é, o ponto final da evolução ideológica da humanidade e a universalização da democracia liberal ocidental como a forma final de governo humano"322.
}

As palavras de Collor reproduziam, de maneira quase literal, o entendimento de que o caminho rumo às liberdades democráticas era inexorável e sugeriam que, nesse contexto, o Brasil deveria assumir um papel de protagonismo:

\footnotetext{
"Um a um, vão ruindo os autoritarismos; em toda parte, vão assomando as liberdades. O Brasil, uma das maiores democracias do mundo, não pode senão figurar à frente desse movimento universal de libertação da humanidade e de generalização da inestimável prática do autogoverno, do estado de direito e da estrita observância dos direitos humanos",323.
}

\footnotetext{
321 http://www2.camara.leg.br/camaranoticias/noticias/POLITICA/192177-DRAMATICIDADE-FOI-O-TOMDOS-DISCURSOS-DE-COLLOR-E-GOULART.html

${ }^{322}$ Fukuyama, Francis. "The End of History?", The National Interest, summer 1989, p. 2.

${ }^{323}$ Collor de Mello, Fernando. "O Projeto de Reconstrução Nacional”. Brasília: Biblioteca da Presidência da República, 1990, p. 11.
} 
Não seria possível exercer a plenitude democrática, contudo, caso o Brasil não sanasse duas deficiências críticas de seu sistema político. O primeiro deles é a inflação crônica, que "nos desorganiza e nos desmoraliza". O exercício da virtude republicana e do espírito de cidadania exigiam certo "capital de confiança a estabilidade", que inexiste em contexto inflacionário. Além disso, a desmoralização decorrente da inflação transcende as fronteiras nacionais, desgastando profundamente a imagem do Brasil no mundo. "Um país que admite conviver para sempre com a ciranda inflacionária pode ser respeitado pelo seu tamanho e potencial, nunca por seu desempenho efetivo". Por isso mesmo, Collor evocava a liquidação da inflação como a meta número um, o propósito imediato de seu governo ${ }^{324}$.

O outro problema urgente a ser superado relacionava-se ao papel do Estado e sua relação com a sociedade. Competia à livre iniciativa, e não ao governo, criar riqueza e dinamizar a economia, cabendo ao último "planejar sem dirigismo o desenvolvimento e assegurar a justiça, no sentido amplo e substantivo do termo". O Estado, para o novo presidente, não seria produtor, mas promotor do bem-estar coletivo. "Daí a certeza de que, no plano internacional, são as economias abertas as mais eficientes e competitivas, além de oferecerem bom nível de vida aos seus cidadãos, com melhor distribuição de renda". No caso brasileiro, seria fundamental concluir o ciclo de liberalização política, aberto com a transição democrática, com a modernização econômica, que seria instituída pela privatização e pela abertura de mercado. Com relação ao capital estrangeiro, temática sempre polarizadora no debate público brasileiro ${ }^{325}$, Collor alinhava-se às perspectivas liberais tornando o Brasil "hospitaleiro" em relação ao investimento externo, mas sem privilegiá-lo. "Não nos anima a ideia de discriminar nem contra nem a favor dos capitais externos, mas esperamos que não falte seu concurso para a diversificação da indústria, a ampliação do emprego e a transferência de tecnologia em proveito do Brasil" 326 .

Logo em sequência, Collor dedica parte expressiva de sua fala ao que chama de “imperativo ecológico", um dos limites fundamentais à economia de mercado. "Pertenço à geração que lançou um grito de alerta contra um modelo de crescimento que caminhava às cegas para o extermínio da vida sobre a Terra”, afirmou o presidente, em tons semelhantes àqueles dos alarmistas ambientais que tanto desconfiavam do Brasil. Fernando Collor segue no tema, narrando os pontos que havia levantado em sua viagem ao exterior, rejeitando a abordagem discriminatória do tema entre governos e reiterando o compromisso brasileiro pelo

\footnotetext{
${ }^{324}$ Collor de Mello, “O Projeto...”, p. 12-13.

${ }^{325}$ Ver, por exemplo, Cervo e Bueno, 2002.

${ }^{326}$ Collor de Mello, "O Projeto...", p. 16.
} 
esforço multilateral conjunto em prol do "desenvolvimento com preservação", da "defesa da soberania" com uma "atitude positiva e consequente".

Por fim, Collor debruça-se sobre a política externa, área marcada pelo dinamismo e pela ascensão de grandes espaços econômicos. Aponta a necessidade de "buscar fórmulas novas de inserção do País no mundo", de uma política exterior que, munida de "sensibilidade nova", sintonizada com os objetivos de reconstrução nacional e com a necessidade de modernização do Brasil, não se renda a "timidez e recuo" de tempos passados:

\begin{abstract}
"Uma das tônicas do Brasil moderno há de ser a participação ativa nas grandes decisões internacionais. Não por pretensão de hegemonia ou por vontade de poder, que a tradição brasileira repele. Mas porque, hoje, a interdependência exige que todo ato de governo seja uma permanente combinação de variáveis internas e externas. Para um país de nossas dimensões, com nossa determinação de desenvolvimento, não há opção melhor que a de ter parte ativa nas decisões internacionais" ${ }^{327}$.
\end{abstract}

Com efeito, a atuação multilateral do Brasil foi fortemente impactada pela retórica da modernização, que havia orientado o governo Collor desde o princípio. "Não-proliferação, direitos humanos, meio-ambiente foram alguns dos temas globais em que as postulações externas brasileiras, sob essa ótica, evoluíram de padrões excessivamente rígidos e protecionistas para atitudes mais transitivas de cooperação internacional”, destaca o embaixador Luiz Felipe Seixas-Corrêa ${ }^{328}$. Muitas das aberturas foram táticas e refletiam a necessidade de recuperar a credibilidade brasileira - como a questão indígena, que poderia colocar em jogo a soberania brasileira a partir de interpretações do direito de ingerência. Outras consolidaram-se como bandeira do governo ao longo de todo o processo, como foi a questão das crianças, consubstanciada no Estatuto da Criança e do Adolescente, de julho de $1990^{329}$.

Destaca-se, também, a questão mais ampla dos Direitos Humanos, marcada por uma importante mudança na metodologia de tratamento do tema em plano internacional - agora abarcando, de maneira inédita, o papel ativo da sociedade civil organizada, como nos mostra Rezek:

\footnotetext{
“A política brasileira no domínio dos direitos humanos caracteriza-se, hoje, pelo amplo diálogo com a comunidade internacional, governamental e nãogovernamental, motivado pela nossa convicção de que a proteção dos direitos humanos representa preocupação legítima de todos. O Brasil tem consciência de que dificuldades nesse campo ainda perduram, mas não poupará esforços no sentido de
}

\footnotetext{
${ }^{327}$ Collor de Mello, 1990, p. 19.

${ }^{328}$ Seixas-Corrêa, Luiz Felipe. A Palavra do Brasil nas Nações Unidas, p. 517.

${ }^{329}$ Ver a participação de Collor na Cúpula da Criança das Nações Unidas, em 1990.
} 
superá-las. Respeitar e fazer respeitar os direitos humanos é prioridade absoluta do Governo brasileiro" ${ }^{330}$.

No plano regional, afora as tratativas específicas de integração com a Argentina, também prevalecia a retórica modernizadora. Em seu primeiro discurso fora do Brasil, Collor sustenou que a "modernização" era um desafio crucial a ser cumprido pelos países em desenvolvimento, sendo a integração "um passo essencial para modernizar nossas economias e para ajustar seu potencial competitivo às novas configurações econômicas que despontam no cenário internacional" ${ }^{331}$. No plano bilateral, o roteiro de visitas presidenciais é expressivo da inflexão dada pelo governo em sua política externa:

\section{Tabela 2 - Viagens presidenciais na terceira fase do governo Collor (mai/91 a abr/92)}

\begin{tabular}{|c|c|c|}
\hline Data & Países & Motivo da viagem \\
\hline 4 de junho & Paraguai & Participação na Assembleia Geral da OEA \\
\hline 6 a 11 de junho & Itália e França & $\begin{array}{l}\text { Abertura da Copa do Mundo e encontro } \\
\text { com empresários }\end{array}$ \\
\hline 5 e 6 de julho & Argentina & $\begin{array}{l}\text { Assinatura da Ata de Buenos Aires sobre a } \\
\text { criação do Mercado Comum do Cone Sul }\end{array}$ \\
\hline 20 de julho & Venezuela & $\begin{array}{l}\text { Inauguração da Rodovia Gran Sabana (Boa } \\
\text { Vista-Caracas) }\end{array}$ \\
\hline $\begin{array}{l}22 \text { de setembro a } 2 \\
\text { de outubro }\end{array}$ & EUA e Europa & $\begin{array}{l}\text { Participação na Assembleia Geral das } \\
\text { Nações Unidas } \\
\text { Visita à República Checa e Eslováquia }\end{array}$ \\
\hline 11 a 13 de outubro & Venezuela & $\begin{array}{l}\text { Encontro com presidentes latino-americanos } \\
\text { no Grupo do Rio para discutir a proposta } \\
\text { dos EUA sobre dívida externa }\end{array}$ \\
\hline 20 a 28 de outubro & Portugal & $\begin{array}{l}\text { Reunião com o presidente e o primeiro- } \\
\text { ministro português }\end{array}$ \\
\hline $\begin{array}{l}9 \underset{ }{9} 15 \text { de } \\
\text { novembro }\end{array}$ & Japão & Entronização do Imperador Akihito \\
\hline $\begin{array}{l}20 \quad \text { a } 22 \text { de } \\
\text { fevereiro de } 1991\end{array}$ & Antártida & $\begin{array}{l}\text { Visita à estação brasileira Comandante } \\
\text { Ferraz }\end{array}$ \\
\hline $\begin{array}{l}11 \text { de março de } \\
1991\end{array}$ & Uruguai & Assinatura de atos de cooperação \\
\hline $\begin{array}{l}26 \text { e } 27 \text { de março } \\
\text { de } 1991\end{array}$ & Paraguai & $\begin{array}{l}\text { Assinatura do Tratado do Mercado Comum } \\
\text { do Cone Sul }\end{array}$ \\
\hline
\end{tabular}

Fonte: Adaptado de OESP, 10 de dezembro de 1991, p. 4

\footnotetext{
${ }^{330}$ RPEB, "Dia Internacional dos Direitos Humanos", out-dez 1990, p. 107.

${ }^{331}$ FSP, "Em discurso na OEA, Collor prega integração com $1^{\circ}$ mundo", 5 de junho de 1990, p. A-4.
} 


\subsection{Do discurso à prática: modernização e integração competitiva}

Além das questões normativas que se alteraram profundamente no início do governo, a chegada de Collor ao poder também representa uma importante mudança de comportamento político e econômico, com repercussões nos fronts doméstico e internacional. No campo político, tem-se o início de um embate entre Executivo e Legislativo, com a ascendência do primeiro sobre o segundo por meio do uso ostensivo de medidas provisórias (MPs). Muitas delas foram aprovadas não porque representavam o interesse do Congresso, mas devido às circunstâncias excepcionais das eleições de 1989 - os expressivos 35 milhões de votos garantiam a Collor, ao menos de saída, ampla legitimidade popular, enquanto a legislatura ainda era a mesma da Constituinte, de 1987 - e, acima de tudo, da situação econômica do país na virada da década ${ }^{332}$.

A nova política industrial e de comércio exterior desdobrou-se em duas medidas imediatas, parte integrante do Plano Brasil Novo - "pacote" de 22 medidas provisórias lançadas no dia seguinte à posse, 16 de março de $1990^{333}$. A primeira delas foi o fim, de maneira abrupta e drástica, das restrições não-tarifárias às importações e exportações. O novo presidente eliminou todo o poder discricionário do governo para autorizar exportações e licenciar importações; abandonou a lista de reserva de mercado, que proibia a importação de cerca de 1500 produtos; pôs fim às isenções e reduções de tarifas de importações, com algumas exceções aplicáveis à Zona Franca de Manaus.

Realizou-se, concomitantemente, uma ampla reforma das instituições de governo e simplificação das normas e procedimentos. A Câmara de Comércio Exterior (CACEX) e a Comissão de Política Aduaneira (CPA), órgãos que se incumbiam das restrições de importação e dos incentivos fiscais, tiveram suas atividades encerradas e suas funções - agora mais enxutas - transferidas ao Departamento de Comércio Exterior (DECEX), de orientação liberalizante e subordinado ao Ministério da Economia ${ }^{334}$. Com tais medidas, pondera Brasilio Sallum Jr., "transformava-se radicalmente a política de comércio exterior de 'substituição de

\footnotetext{
${ }^{332}$ Realizamos, em pesquisa anterior, discussão sobre as relações Executivo-Legislativo no contexto das MPs do governo Collor. Ver Casarões, Guilherme. "A Economia Política do Governo Collor: discutindo a viabilidade de governos minoritários sob o presidencialismo de coalizão" (Dissertação de mestrado, DCP-USP), 2008.

${ }^{333}$ Ver "Plano Collor". Revista de Economia Política, vol. 10, no. 3 (39), 1990. Além da descrição e do resumo das medidas, a edição da revista também traz análises conjunturais de diversos especialistas, que repercutiram na grande mídia nos dias imediatamente subsequentes ao lançamento do plano.

${ }^{334}$ Kingstone, Peter. Crafting Coalitions for Reform, p. 159.
} 
importações' do Estado Varguista; não se gerava uma nova política, mas se dava o primeiro passo para isso",335.

Três meses após o lançamento das primeiras medidas - e ainda se recompondo da perplexidade causada pelo Plano Collor - a ministra da Economia, Zélia Cardoso de Mello, anuncia as Diretrizes gerais para a política industrial e de comércio exterior. Tratou-se do "mais espetacular conjunto de medidas apresentado pelo governo em 1990, depois do plano de estabilização" ${ }^{336}$. A ideia da nova política, como já se vinha aventando desde a campanha eleitoral, era mexer em pontos sensíveis da vida produtiva, de modo a expor gradualmente a superprotegida indústria nacional à concorrência externa. Entre os anúncios do dia 26 de junho e que configuraram a Política Industrial e de Comércio Exterior (PICE) estavam:

- O estabelecimento da tarifa aduaneira como única barreira comercial, já a partir do segundo semestre de 1990;

- A definição de um cronograma destinado a reduzir as tarifas no quinquênio 19901994, da média de 35\% verificada em 1990 para 20\% em 1994;

- A reafirmação do fim da lista de 1200 produtos de importação proibida (Anexo C da extinta CACEX), que datava de 1975, e a eliminação dos controles quantitativos representados pelos programas de importação das empresas;

- A redução da média de $85 \%$ para um máximo de $70 \%$ o índice de nacionalização exigido nas operações com o governo;

- O estabelecimento de alíquota zero, a partir de $1^{\circ}$ de julho, para importação de máquinas, equipamentos, peças e componentes, assim como matérias-primas e produtos intermediários sem similar nacional;

- A utilização seletiva dos créditos oficiais, dirigidos exclusivamente para os investimentos necessários à reestruturação da indústria brasileira, ao desenvolvimento científico e tecnológico e à expansão do comércio exterior;

- A redução do Estado a uma função "articuladora" em matéria de financiamento, produção de bens e serviços básicos - redefinindo, portanto, “o ambiente econômico onde operam as estatais";

\footnotetext{
${ }^{335}$ Sallum Jr.,2011.

${ }^{336}$ Gouvêa, Leila Vilas Boas. Modernização ou Sucateamento? Política Industrial e de Comércio Exterior. São Paulo: Círculo do Livro, 1991, p. 21.
} 
- A recomendação de um "maior envolvimento" do capital estrangeiro no país, a partir da eliminação de "restrições setoriais anacrônicas" e de "preconceitos residuais" e do estímulo à pesquisa e desenvolvimento;

- A revisão do Código de Propriedade Industrial, instituído pela Lei 5.772/71, a fim de excluir "a extensão da produção patentária a processos e produtos farmacêuticos em prazos e condições adequados aos objetivos gerais da PICE"337.

Embora não restem dúvidas de que as medidas contidas no PICE (mais tarde complementadas por outros programas ${ }^{338}$ ) refletiam preocupações econômicas estruturais e conjunturais, há também um importante componente de política internacional atrelado às decisões descritas acima, para além das questões de investimento e comércio exterior. Não nos parece coincidência, por exemplo, que reações animadoras - até mais vocais que aquelas vindas dos setores empresariais - tenham partido das representações estrangeiras no Brasil. O chefe da Divisão de Macroeconomia, Finanças e Comércio Internacional do Departamento Brasil do Banco Mundial, Demetris Papageorgiou, declarou, com entusiasmo, que "o programa de liberalização comercial anunciado pelo governo brasileiro é o mais radical já adotado na América Latina, à exceção do Chile, além de constituir-se na decisão mais importante do governo Collor de Mello, depois do plano de estabilização da economia”339

Sinais positivos também vieram da embaixada dos Estados Unidos, com efeitos relativamente rápidos. Em 27 de junho de 1990 - um mês depois do lançamento do PICE - a Casa Branca suspendeu as sanções comerciais impostas contra o Brasil no final de 1988, em protesto à recusa do país de proteger propriedade intelectual de produtos e processos farmacêuticos. A decisão foi tomada após o anúncio da decisão de enviar ao Congresso, até o fim do ano, um projeto de lei estabelecendo ampla proteção às patentes farmacêuticas, conforme previsto nas Diretrizes. As sanções, que tomaram a forma de uma sobretaxa de 100\% aplicada a várias categorias de produtos, já representavam uma perda estimada de US\$ 300 milhões em receita de exportação. Para Paulo Sotero, do ponto de vista político, a resposta norte-americana abre caminho "para a resolução do último tema complicado do contencioso comercial entre Brasil e Estados Unidos e encerra um capítulo de confrontação na

\footnotetext{
${ }^{337}$ Gouvêa, 1991, p. 22-5.

${ }^{338}$ Como o Programa Brasileiro de Qualidade e Produtividade (PBQP), lançado em novembro de 1990, e o Programa de Competitividade Industrial (PCI), editado em fevereiro de 1991.

339 Gouvêa, 1991, p. 31.
} 
história das relações entre os dois países, aberto no dia 7 de setembro de 1985, quando o governo Reagan denunciou a política brasileira de informática"340.

\subsection{A relação com os Estados Unidos e o problema da dívida externa}

No plano das relações bilaterais, a mais absoluta prioridade da política externa brasileira foi conferida ao relacionamento com os Estados Unidos. Não acreditamos, contudo, que tenha se tratado de um alinhamento irresponsável ou subserviente. O senso de urgência decorria do fato de que, seja para atender a demandas domésticas de curto prazo, que envolviam a reforma do Estado ou o restabelecimento dos indicadores econômicos, ou para recuperar a credibilidade do Brasil perante os olhos da comunidade internacional, aproximarse do governo Bush parecia imperativo. Isso explica, entre outras coisas, a atenção dedicada por Collor, ainda como presidente eleito, à viagem aos Estados Unidos, durante a qual se tratou de uma extensa agenda bilateral junto às autoridades norte-americanas. Na posse, o presidente deixou clara a intenção de rever o relacionamento bilateral com os EUA, herdado em condições precárias do governo Sarney:

\footnotetext{
"Pretendo exercer (...) a melhor disposição para o diálogo e o entendimento. $\mathrm{Na}$ convivência entre duas democracias, deve prevalecer o reconhecimento das suas características próprias, o respeito por opiniões distintas ou mesmo divergentes. Tenho certeza de que diferenças de interesse e percepção, naturais em intercâmbio denso como o nosso, serão tratadas de forma construtiva, para benefício mútuo. O Brasil deseja sincera e fortemente que as relações com os Estados Unidos tenham sentido positivo. Entre parceiros de tão longa data, com afinidades passadas e presentes, são as coincidências e não as discrepâncias que devem dar o tom do diálogo",341
}

Embora o discurso de Collor tenha sido bem recebido em Washington, as medidas de choque impostas pelo pacote econômico lançado no dia seguinte deixaram uma aura de incerteza nas relações. Os elogios públicos vieram do presidente Bush e seus principais assessores, como o Secretário do Tesouro, Nicholas Brady, o presidente do Federal Reserve Board, Alan Greenspan, e a United States Trade Representative, Carla Hills ${ }^{342}$. Agradavalhes, em particular, as medidas liberalizantes do chamado Plano Collor, sintonizadas com o ideário liberal defendido pelo Consenso de Washington. A quebra de contratos envolvida no

\footnotetext{
${ }^{340}$ OESP, “EUA vão suspender sanções comerciais”, 27 de junho de 1990, p. 29.

${ }^{341}$ Collor de Mello, "O Projeto...", p. 16.

${ }^{342}$ Brooke, James. "A Swift and Hard Fall for Brazil", New York Times, 10 de abril de 1990.
} 
confisco dos ativos financeiros, por outro lado, gerava apreensão entre os interlocutores do Brasil nos Estados Unidos ${ }^{343}$, especialmente entre empresários e investidores.

Os dois temas mais prementes na agenda bilateral eram, segundo o embaixador Marcílio Marques Moreira, a dívida externa e a questão das patentes. Nenhum dos dois, por razões distintas, foi encaminhado imediatamente. No caso da dívida, foram seis meses - de março a outubro - de negociações até que o Brasil apresentasse uma proposta de renegociação. $\mathrm{O}$ argumento do governo brasileiro era absolutamente plausível: enquanto não se resolvessem os problemas domésticos, que o Plano Collor viera atacar, o país não retomaria o pagamento da dívida externa aos credores privados ${ }^{344}$.

Inicialmente, a posição brasileira foi encarada sem grandes sobressaltos entre as autoridades norte-americanas e mesmo entre representantes dos bancos privados. No dia 21 de março, menos de uma semana após a posse do governo Collor de Mello, realizou-se um painel de debates sobre um ano de existência da "Iniciativa Brady". Nele, o subsecretário do Tesouro, David Mulford, fez referência elogiosa ao novo elenco de medidas econômicas adotado recentemente pelo novo presidente. De acordo com Mulford, era de interesse geral que o Brasil pudesse, num futuro próximo, chegar a um acordo adequado com os bancos comerciais - esperando, para tanto, que as medidas econômicas adotadas pudessem capacitar o Brasil a participar da iniciativa norte-americana de redução do serviço da dívida. Um dos representantes do setor financeiro, William Rhodes, do Citicorp/Citibank, também revelou estar otimista com relação ao programa de ajustes do governo Collor, exortando as instituições multilaterais a permitir maior flexibilidade na alocação de recursos destinados ao alívio da dívida, bem como demandando dos bancos comerciais o seguimento, em circunstâncias apropriadas, do aporte de novos empréstimos aos "países que ora envidam esforços no sentido de reformular suas economias" ${ }^{\text {345. }}$.

A aura positiva permaneceu nas semanas que se seguiram. Em princípios de abril, Zélia fez sua primeira viagem a Washington desde a posse. Proveniente de Montreal, onde havia discursado perante a $31^{\mathrm{a}}$ Reunião Anual do BID, a ministra encontrou-se com todas as autoridades econômicas do país: Brady, Hills, Greenspan, além de Camdessus, do FMI. Todos ficaram bem impressionados, num primeiro momento, com o pragmatismo e a vontade política da ministra de levar adiante duras reformas econômicas. As palavras mais utilizadas para descrever a reação das autoridades com quem Zélia se encontrou na capital norte-

\footnotetext{
${ }^{343}$ Moreira, Marcílio Marques. Diplomacia, Política e Finanças. Rio de Janeiro: Objetiva, 2001, p. 233.

${ }^{344}$ Idem, p. 236

${ }^{345}$ Telegrama BRASEMB WASHINGTON para EXTERIORES, no. 0307, em 22/03/1990.
} 
americana foram "entusiasmo" e "fascinação" - no caso de Camdessus, a palavra que interlocutores utilizaram para descrever seu estado de ânimo após o almoço oferecido à ministra foi "ebuliente"346. Embora não se tratasse de um apoio incondicional às medidas do Plano Collor, a simpatia das autoridades era o endosso de que o novo governo precisava para legitimar, por um lado, a truculência das reformas e, por outro, a posição irredutível que o Brasil mantinha sobre a questão do pagamento da dívida aos credores privados.

Em coletiva, Zélia afirmou que o governo brasileiro não pretendia reiniciar tão cedo o pagamento da dívida externa aos bancos privados e que as negociações com o Fundo Monetário e com os bancos só poderiam ser retomadas a partir do dia 16 de abril, quando o Congresso terminasse de apreciar as medidas provisórias relativas ao pacote econômico do mês anterior. $\mathrm{O}$ debate sobre o pagamento do principal e dos juros - que o país havia deixado de honrar um ano antes - ficaria para uma segunda etapa. "Vamos realizar o ajuste interno, [por] quanto tempo for necessário. Assim, passaremos à fase de apresentar aos órgãos internacionais as nossas condições para renegociar a dívida"347.

Aos poucos, o ceticismo destes credores começou a aparecer. A posição da ministra, considerada intransigente por vários interlocutores nos EUA, dificultava a liberação de novos créditos para os próprios ajustes demandados pelo Plano Collor. Não agradava às autoridades americanas a moratória informal imposta pelo Brasil sobre os bancos privados. Tanto a política do Fundo Monetário de concessão de empréstimos de curto prazo quanto a estratégia do governo dos EUA de negociar a redução das dívidas do Terceiro Mundo, no contexto do Plano Brady, dependia essencialmente do diálogo entre credor e os bancos a respeito dos atrasados - que, no caso do Brasil, já somavam algo em torno de US\$ 5 bilhões. Mesmo México e Venezuela, que chegaram a acordos para reduzir suas dívidas, passaram por um calvário de negociações com os bancos privados e, mesmo nos tempos mais críticos, mantiveram o pagamento de seus vencimentos em dia $^{348}$.

O recado dado pelo governo Bush à ministra Zélia, na pessoa do secretário Brady, era taxativo: o Brasil deveria diminuir, até junho, o volume de atrasos com os bancos credores ${ }^{349}$. Embora os EUA compreendessem as dificuldades políticas de dar seguimento às discussões

\footnotetext{
${ }^{346}$ OESP, “Ainda há dúvidas sobre o Plano Collor nos EUA”, 06 de abril de 1990, p. 7.

${ }^{347}$ FSP, "Zélia descarta pagamento imediato da dívida", 04 de abril de 1990, p. B-11.

${ }^{348}$ FSP, “Zélia descarta...”, 04 de abril de 1990.

349 A despeito da proximidade da data, o prazo tinha razão de ser: em junho, as autoridades norte-americanas avaliariam a qualidade dos créditos brasileiros junto aos bancos, e o resultado poderia ser uma reclassificação para value impaired - o que seria equivalente a considerar o país inadimplente, como havia sido feito com a Argentina em 1985. Ver World Bank, Argentina: from insolvency to growth. Washington, D.C.: World Bank, 1993; Além disso, os atrasos complicariam a situação dos bancos, cujos balanços eram realizados trimestralmente.
} 
da dívida, sobretudo diante das expectativas quanto à aprovação legislativa ao Plano Collor e das reações da opinião pública brasileira ${ }^{350}$, a comunidade financeira parecia menos disposta a fazer concessões ao novo governo. Aparentemente, o sentimento que prevalecia entre os executivos era de que Zélia queria negociar sem ceder, ou seja, que o governo brasileiro desejava um acordo de redução da dívida, mas sem disposição de quitar os atrasados ou os $\operatorname{juros}^{351}$.

O setor privado norte-americano também tinha motivos para desconfiar dos rumos da economia brasileira. Enquanto a ministra da Economia encontrava-se nos EUA, uma matéria foi publicada no Wall Street Journal sustentando que as reformas econômicas implantadas por Collor colocariam em risco o lucro de grandes multinacionais com operações históricas no Brasil, como Union Carbide, General Motors, Ford, Alcoa e Champion International algumas podendo perder algo em torno de $10 \%$ de seus lucros globais em função da recessão em que o país entraria.

Ao mesmo tempo, continuavam as restrições às exportações norte-americanas. $\mathrm{O}$ Brasil figurava em sexto lugar dentre os países mais protecionistas com relação aos produtos vindos dos EUA, de acordo com a lista anual divulgada pelo Departamento do Comércio ${ }^{352}$. Isso não somente afetava o setor privado daquele país, mas mobilizava esforços governamentais expressivos para retaliar economias que fossem consideradas afeitas a práticas "injustas" de comércio. A política norte-americana de operar como a "polícia" do comércio mundial já vinha sendo criticada há algum tempo por analistas dentro dos próprios Estados Unidos, sobretudo porque colocava em risco as relações com o Japão (responsáveis por $44 \%$ de todo o déficit comercial americano) e tinha o potencial de frustrar as negociações da Rodada Uruguai do GATT, uma vez que estreitavam a margem de concessões multilaterais por parte dos países que estavam sendo achincalhados unilateralmente pelo governo Bush. De acordo com editorial do New York Times, de 17 de abril de 1990, tratava-se de uma "lei ruim", sendo que o momento era "particularmente ruim" para invocá-la novamente:

\footnotetext{
"Sim, outros países têm barreiras injustas. Assim como os Estados Unidos. Sim, alguma pressão é justificável, e sim, algumas ameaças funcionam. Mas o benefício é limitado e traz um custo alto. Outros países corretamente ressentem-se da petulância americana em arrogar, para si, o papel do policial do que é justo",353.
}

\footnotetext{
${ }^{350}$ FSP, "EUA cobram do Brasil juros atrasados", 05 de abril de 1990, p. B-11.

${ }^{351}$ FSP, "Bancos avaliam o plano", 05 de abril de 1990, p. B-11.

${ }^{352}$ Ficava somente atrás de Japão, Comunidade Europeia, Canadá, Coreia do Sul e Índia.

${ }^{353}$ NYT, "America, the arrogant trade cop", 17 de abril de 1990.
} 
Por isso mesmo, o encontro entre Zélia e Carla Hills - conhecida como a figura mais assertiva do gabinete do presidente Bush - foi particularmente sensível ao novo governo brasileiro. A sombra das retaliações impostas pelo governo Reagan, três anos antes, ainda pairava sobre as relações bilaterais ${ }^{354}$. Além disso, os temas de discórdia permaneciam os mesmos: o fim derradeiro da reserva de mercado de informática - cujas amarras já vinham sendo afrouxadas desde meados de 1988 - e a solução da questão das patentes, sobretudo nos setores farmacêutico e químico ${ }^{355}$. Não parece trivial, portanto, o interesse norte-americano em vincular, ainda que informalmente, o encaminhamento das questões comerciais à resolução dos problemas ligados à dívida. A credibilidade da imagem brasileira perante o governo dos EUA era fundamental para que a tão desejada "agenda positiva" pudesse ser, finalmente, colocada em marcha. Isso explica as promessas de Zélia - que declarou, ao fim da reunião, que a administração Collor, nos meses seguintes, derrubaria algumas tarifas alfandegárias, suspenderia subsídios a exportações brasileiras e acabaria com o privilégio das empresas brasileiras em copiar produtos estrangeiros sem o devido pagamento de royalties ${ }^{356}$.

Ainda que as conversas não tivessem sido completamente favoráveis aos interesses brasileiros e às circunstâncias econômicas do novo pacote, o diretor do Departamento de Assuntos Internacionais do Ministério da Economia, Clodoaldo Hugueney, considerou a viagem de Zélia bem-sucedida, na medida em que "cumpriu plenamente seu objetivo, de uma primeira exposição internacional do plano de estabilização". O diplomata informou que a expectativa do governo Collor era concluir a avaliação do cenário após os impactos das mudanças econômicas para que se pudesse dar continuidade às negociações da dívida. $\mathrm{O}$ próximo passo após fechado o ciclo inicial do plano Collor envolveria o recebimento de duas missões estrangeiras: do BID, chefiada pelo próprio presidente do banco, Enrique Iglesias, para a negociação de contratos e empréstimos da ordem de US\$ 1 bilhão, mais US\$ 2 bilhões do Banco Mundial, também destinados à capacitação tecnológica de empresas e projetos na área de ciência e tecnologia; mais tarde, uma missão técnica do FMI se responsabilizaria por levantar dados sobre a economia brasileira, de modo a iniciarem-se as negociações que viabilizassem o segundo ciclo do programa de estabilização, dando-lhe o devido respaldo internacional e permitindo, assim, que fossem retomadas as conversar com os bancos ${ }^{357}$.

Os efeitos positivos da turnê internacional da equipe econômica foram sentidos em poucas semanas. Como a preocupação do governo americano, na figura de Carla Hills, estava

\footnotetext{
${ }^{354}$ Ver Vigevani, op. cit, 1995.

${ }^{355}$ FSP, “Carla Hills vai criticar restrições às exportações norte-americanas”, 03 de abril de 1990, p. B-4.

${ }^{356}$ FSP, “Zélia promete ampliar reforma comercial”, 04 de abril de 1990, p. B-4.

${ }^{357}$ FSP, “Acordo com FMI antecede pagamento da dívida", 05 de abril de 1990, p. B-11.
} 
canalizada na Rodada Uruguai do GATT, entendida pela administração Bush como o palco vital para a promoção do livre comércio, decidiu-se aliviar a pressão sobre o governo Collor a despeito de forte oposição legislativa, sobretudo por parte da bancada democrata, que achava a decisão precoce e acreditava que a mudança de legislação poderia "envenenar" as futuras negociações ${ }^{358}$. Dos três maiores países que impunham barreiras aos produtos americanos, aliás, somente a Índia permanecia na lista de unfair trade, após concessões realizadas por Japão e Brasil. No caso brasileiro, em particular, Hills tratava as mudanças econômicas recentemente empreendidas como "fantásticas", que compunham o quadro de uma "história muito feliz" 359 .

Contou-se, para essa boa impressão, não somente a viagem de Zélia a Washington, como também um esforço diplomático empreendido pelo Itamaraty. Na segunda semana de abril, o Secretário Geral de Política Exterior, Marcos Azambuja, participou de um encontro informal com Hills em Puerto Vallarta, no México. Os limites e oportunidades das negociações brasileiras foram bem especificados no telegrama secreto enviado pela Embaixada em Washington para o MRE, datado do dia 11:

\begin{abstract}
"Como republicana ativa, comunga dos princípios básicos de seu partido, especialmente do liberalismo econômico (...). Como membro do Executivo, tem que lidar com pressões do Congresso, não só dos democratas, mas também do partido a que pertence. Assim, muitas vezes (...) 'joga para a plateia'. Exemplo dessa atitude são suas declarações públicas (...) sobre sua determinação de abrir mercados para produtos norte-americanos, com 'handshake' ou com 'crowbar'. Parece nutrir ambições políticas mais altas, e certos comentaristas da imprensa chegam a nela identificar uma candidata potencial a vice-presidente no 'ticket' republicano para 1996.
\end{abstract}

Quanto aos temas da Rodada Uruguai de maior interesse, parece-me que (...) a rodada em si é o assunto primordial da agenda de Carla Hills (...). Apesar de todo o arsenal de legislação de que dispõe para atuar bilateralmente e até pelo constrangimento multilateral que essa legislação (Seção 301, Seção 201, 'Super 301', 'Special 301') causa aos Estados Unidos, Carla Hills está convencida de que é essencial chegar a resultados concretos e abrangentes no GATT para se obter efetiva abertura do comércio internacional de bens e serviços.

Apesar do enorme interesse inicial demonstrado pelos Estados Unidos nos grupos de serviços, TRIPS e TRIMS, parece-me que, hoje, os três assuntos passaram para um plano, se não secundário, pelo menos não tão agressivamente proeminente. Talvez (...) a necessidade de contar com o apoio de países como o Brasil em questões mais

\footnotetext{
${ }^{358}$ FSP, "EUA podem tirar Brasil na lista de retaliação", 27 de abril de 1990, p. B-11. Ver também FSP, "EUA decidem retirar as ameaças de retaliação comercial ao Brasil", 28 de abril de 1990: "O recuo norte-americano (...) foi condenado veementemente no Congresso (...). Há informações de que a bancada do Partido Democrata, majoritário, vai, em represália, tentar vetar todas as futuras negociações comerciais propostas pelo governo federal" (p. B-11).

${ }^{359}$ NYT, "India is expected to remain on U.S. trade 'hit list"”, 27 de abril de 1990.
} 
essenciais (agricultura) (...) tenham feito com que a ênfase nessas questões se reduzisse ${ }^{, 360}$.

As negociações, no entanto, não eram realizadas somente com autoridades norteamericanas. No front europeu, o ministro da Infra-Estrutura, Ozires Silva, reuniu-se com empresários e banqueiros britânicos no dia 27 de abril, na sede do Lloyds Bank - um dos principais credores privados do Brasil - acompanhado do embaixador em Londres, Paulo Tarso Flecha de Lima. Ao final do encontro, o ministro declarou que seus interlocutores haviam apreciado a exposição que fez sobre o plano de estabilização brasileiro, mas deixaram claro que "quer[ia]m receber seu dinheiro de volta". Além do almoço com os credores, Ozires manteve reuniões com autoridades do governo britânico, nas quais discutiu as privatizações brasileiras e o interesse dos bancos britânicos em participar do financiamento das vendas de estatais $^{361}$.

Nota-se, a essa altura, as imbricadas relações entre temas e atores que balizavam a política externa brasileira nos movimentos iniciais do governo Collor. As negociações eram realizadas em três níveis - multilateral, com as instituições financeiras; bilateral, com os Estados Unidos, e não-estatal, com os bancos privados - e a respeito de múltiplos temas simultâneos - privatização e patentes, tendo a dívida externa como o epicentro dos problemas brasileiros. A estratégia do novo governo era resolver, inicialmente, os gargalos que o país possuía no plano bilateral, tendo encontrado na reconstrução da imagem a principal via de recuperação das relações com o chamado Primeiro Mundo. Aumentar o perfil brasileiro perante autoridades governamentais norte-americanas e europeias poderia conduzir, num segundo momento, a uma renovação dos empréstimos por parte das organizações financeiras, sobre as quais os países industrializados tinham ascendência. Ao mesmo tempo, buscava-se conter as pressões políticas que sistematicamente vinham dos grandes bancos privados. As promessas realizadas ao governo Bush, em particular, garantiam ao Brasil margem de manobra para continuar postergando o pagamento dos juros e dos atrasados aos credores. No limite, seguindo a máxima de Lampedusa ${ }^{362}$, a relação com os Estados Unidos precisava mudar dramaticamente para que a estratégia de negociação da dívida, autonomista em sua essência, permanecesse a mesma.

De fato, Zélia chegou a Washington obstinada a manter a posição de não voltar a pagar os atrasados e juros aos bancos sem que a economia estivesse recuperada. Para dar mais

\footnotetext{
${ }^{360}$ Telegrama SECRETO-URGENTE BRASEMB WASHINGTON para EXTERIORES, no. 0304, em $10 / 04 / 1990$

${ }^{361}$ FSP, "País leva plano ao FMI em maio, diz Ozires", 28 de abril de 1990, p. B-1.

362 "Everything must change so that everything can stay the same"
} 
respaldo à posição brasileira, sobretudo diante do recrudescimento das pressões políticas, o governo Collor nomeou, pouco tempo antes da viagem de Zélia, um diplomata de carreira para a negociação da dívida ${ }^{363}$. O embaixador Jório Dauster havia sido recentemente desligado do Instituto Brasileiro do Café ${ }^{364}$, que presidia desde 1987 e no qual conduzira diversas negociações internacionais. Era importante, naquele momento, evitar o desgaste de utilizar as autoridades máximas brasileiras nas tratativas diárias sobre a questão da dívida aquilo que o próprio Dauster chamaria, mais tarde, de "tática suicida" - e nomear um negociador desligado da máquina administrativa ${ }^{365}$. O caso mexicano era exemplar: ao assumir, o governo Salinas de Gortari nomeou Angel Gurría para a condução das negociações, na qualidade de subsecretário para Assuntos Financeiros Internacionais ${ }^{366}$, com resultados positivos nos primeiros anos de mandato ${ }^{367}$.

A nomeação de Jório Dauster não fugiu dos padrões de indicação do governo Collor. Segundo depoimento à revista Insight/Inteligência, embora lhe parecesse interessante a tarefa de conduzir as conversas sobre a dívida, ele foi surpreendido pelo convite:

\begin{abstract}
"Não conhecia ninguém no novo governo, não movi uma palha e, hoje, mais de duas décadas depois, com toda a sinceridade, não sei como chegaram ao meu nome, embora economistas ligados ao ministro Dílson Funaro conhecessem minha trajetória como negociador internacional (...).Ao aceitar, porém, eu disse que queria ser uma asa delta descartável ao final do voo (...). [E]xpliquei que, com minha longa experiência no setor público, estava claro que eu deveria ser um personagem com prazo de validade, com data certa para entrar e sair de cena, sem procurar criar espaços burocráticos que provocassem a resistência dos vários órgãos envolvidos na matéria" ${ }^{368}$.
\end{abstract}

O embaixador viajou com Zélia a Washington, já no contexto das preparações para as negociações que se iniciariam a seguir. Às margens da reunião anual do FMI e do Banco Mundial, a ministra discutiu com o diretor-gerente do Fundo, Michel Camdessus, a possibilidade do aporte de novos créditos sem que o Brasil quitasse parcialmente seus débitos com os bancos. A situação, para Camdessus, era delicada: os credores privados haviam levado uma mensagem ao Fundo Monetário solicitando que não se concedessem empréstimos ao

\footnotetext{
${ }^{363}$ A data exata da sua nomeação é incerta. A exoneração de Dauster do cargo de presidente do IBC data de 30 de abril de 1990, sendo que a publicação no DOU é de 2 de maio. Mas seu nome já era aventado como o de negociador da dívida externa desde 12 de abril, pelas informações da coluna Painel, da Folha de São Paulo. ${ }^{364}$ Extinto formalmente pelo Decreto no. 99.240, de 7 de maio de 1990.

365 "Ora, é claro que o general não pode ir para a trincheira!". Dauster, Jório. "Depoimento de Jório Dauster", Insight Inteligência, out-nov-dez 2013, p. 23.

366 Ver http://www.oecd.org/mexico/35147118.pdf

${ }^{367}$ Ver, por exemplo, Gurría, José Angel. La Política de la Deuda Externa. México, DF: Fondo de Cultura Económica, 1993.

${ }^{368}$ Dauster, "Depoimento...", p. 24.
} 
governo brasileiro nas condições por ele apresentadas. Segundo documento do Instituto Financeiro Internacional (IFI), órgão criado e ministrado pelos bancos comerciais, emprestar ao Brasil seria "legitimar a prática do calote". Os banqueiros aproveitaram para criticar, na mesma toada, o Plano Brady, uma vez que representava uma concessão do governo Bush a devedores que utilizavam, sistematicamente, "os atrasos como instrumento de negociação da dívida"369.

A posição dos bancos não mudou a orientação brasileira. O discurso de Zélia durante a reunião do FMI/BIRD manteve o tom duro que o governo já vinha defendendo, sobretudo com relação aos credores privados:

"O espírito de cooperação que nos move não deve obscurecer a ação política subjacente a esta sequência de ações: primeiro cuidamos de arrumar a casa, depois iniciamos os entendimentos com nossos parceiros. Isso significa que as decisões sobre a nossa política econômica antecedem e condicionam os acertos externos" ${ }^{\text {"370 }}$.

Em julho, a equipe econômica lança uma ofensiva diplomática em duas frentes. Antônio Kandir, secretário especial de Política Econômica, foi a Washington retomar formalmente as negociações com o FMI, estabelecendo com o diretor-presidente do Fundo, Michel Camdessus, o cronograma de negociação a ser iniciada com a chegada ao Brasil, no fim daquele mês, de uma missão técnica da instituição. A ministra Zélia, por sua vez, cumpriu uma intensa agenda na Europa, na qual buscou divulgar o plano de estabilização da economia e a nova política industrial. As viagens das autoridades econômicas brasileiras, destacava editorial do Estado de São Paulo,

\footnotetext{
"não visavam apenas a informar seus interlocutores acerca da evolução da economia brasileira: os dois emissários do governo de Brasília procuraram ouvir os representantes dos credores a fim de poderem dar início à parte mais atrasada do programa Brasil Novo, ou seja, o processo de renegociação de nossa dívida externa",371.
}

Os termos da negociação, da parte brasileira, estavam claros. O Brasil não pagaria nada além da sua capacidade, de modo a não colocar em risco o programa de estabilização em marcha. A estratégia utilizada por Zélia era a de anunciar, antecipadamente, que resistiria às pressões, limitando a margem para posteriores concessões que lhe seriam impostas. Na véspera do embarque, a ministra da Economia declarou à imprensa que o Brasil não poderia

\footnotetext{
${ }^{369}$ FSP, “Credores pedem que FMI não empreste ao país”, 04 de maio de 1990, p. B-3.

${ }^{370}$ FSP, "O discurso feito pela ministra Zélia", 08 de maio de 1990, p. B-14.

${ }^{371}$ OESP, "Dívida externa a caminho da normalidade", 24 de julho de 1990, p. 3.
} 
pagar mais de US\$ 1 bilhão em juros da dívida externa naquele ano, o que demonstrava, ao menos na retórica, a indisposição do governo em ceder às pressões dos credores privados. A declaração gerou reações ambíguas entre os bancos: enquanto alguns, sobretudo nos EUA, ficaram aliviados com a possibilidade de o Brasil retomar pagamentos, ainda que abaixo das expectativas, os credores europeus manifestaram seu descontentamento quanto à decisão ${ }^{372}$.

Quatro capitais - Londres, Bonn, Paris e Roma - em cinco dias compunham o roteiro de Zélia na Europa. A ministra manteve encontros com empresários, banqueiros e autoridades governamentais nos países por onde passou, dentre os quais se destacam o encontro com a primeira-ministra britânica, Margaret Thatcher, e seu secretário do Tesouro, John Major ${ }^{373}$; as reuniões com os ministros da Economia e da Cooperação Econômica alemães, Helmut Houssmann e Jürgen Warnke ${ }^{374}$; a conversa com o presidente do Clube de Paris e diretor do Tesouro francês, Jean-Claude Trichet. A expectativa era obter apoio das nações credoras a um acordo com o FMI, antes que o governo voltasse a negociar com os bancos. Voltava-se à equação de pressionar os governos dos países industrializados para que eles, por seu turno, pudessem abrir caminhos no Fundo Monetário e junto aos representantes dos bancos credores.

A despeito dos esforços pessoais de Zélia, complementados pelas negociações realizadas por Dauster em Nova York, houve pouco progresso ao longo do mês de julho. No início de agosto, uma missão do Fundo Monetário foi enviada ao Brasil, de modo a dar início às negociações para a concessão de créditos. Ao ser perguntada sobre um possível prazo para o fechamento do acordo com o FMI, a ministra ressaltou as dificuldades enfrentadas pelo Brasil no contexto das experiências recentes latino-americanas:

\begin{abstract}
"Não sei. Gostaríamos que fosse o mais rápido possível, mas essa não é uma questão simples. O Brasil entra em desvantagem nessa parada. A experiência do México traumatizou muito os credores, porque houve uma pressão muito grande do governo americano para uma redução da dívida. Hoje, a solidariedade que poderíamos ter de outros governos para melhorar a negociação junto aos bancos poderá não se refletir, como há três ou cinco anos. A mesma coisa acontece com o FMI, principalmente em função da Argentina. As negociações com a Argentina e também com a Costa Rica e a Venezuela deixaram uma série de marcas. Então, hoje, há uma posição mais prudente por parte dos bancos, dos governos e do FMI",375
\end{abstract}

Foram 25 dias de negociações, contados da chegada da missão do FMI ao Brasil, para que o governo conseguisse formular uma carta de intenções ao Fundo Monetário. O

\footnotetext{
372 OESP, "Promessa de pagar dívida alivia tensões"; "Credores consideram US\$ 1 bi muito pouco", 14 de julho de 1990, p. 40.

373 OESP, "Reunião com Thatcher entusiasma Zélia”, 17 de julho de 1990, p. 17.

374 OESP, "Bonn apoiará o Brasil no FMI", 18 de julho de 1990, p. 36.

375 OESP, "Ministra defende privatização total", 5 de agosto de 1990, p. 88.
} 
documento, contendo as principais metas para a economia brasileira em 1991, tinha como objetivo orientar a reunião da diretoria do órgão no fim de setembro, na qual seria discutido um acordo stand-by envolvendo US\$ 1,5 bilhão em créditos de curto prazo. Sem esse empréstimo, o Brasil não teria condições de dar sequência à negociação com os bancos credores, que se encontrava interrompida ${ }^{376}$. A estratégia da equipe econômica de Collor continuava sendo a de obter o aval do FMI antes de sentar-se à mesa com os Comitê de Bancos Credores, de modo a obter deles melhores condições na renegociação da dívida e dos juros atrasados. A dificuldade, como nota Sotero, é que o Fundo Monetário,

\begin{abstract}
“que é uma instituição dominada pelos governos dos países credores e tem por função zelar pela estabilidade do sistema financeiro internacional, não poderia dar aval ao programa brasileiro porque, além de a participação dos bancos no seu financiamento não estar assegurada, o Fundo estaria legitimando a moratória brasileira sobre o pagamento da dívida externa"377.
\end{abstract}

O cenário tornava-se ainda mais árido porque os bancos credores norte-americanos, em particular, vinham passando por sérias dificuldades financeiras, em decorrência de fatores domésticos e internacionais. Internamente, preocupavam o escândalo das instituições de poupança e a crise dos devedores do cinturão agrícola do meio-oeste estadunidense. A crise do Golfo, por sua vez, gerava uma situação de incertezas nos mercados mundiais. Isso fazia com que a dívida dos países em desenvolvimento voltasse a ter importância na defesa dos lucros esperados pelos acionistas, tornando os bancos privados mais intransigentes com atrasos no pagamento dos juros - postura que contava com a anuência do Fundo Monetário Internacional e com o endosso do governo dos $\mathrm{EUA}^{378}$. A estratégia adotada pelos negociadores da dívida externa brasileira foi finalmente frustrada em fins de setembro, no contexto da reunião do G-7, em que o diretor-gerente do FMI, Michel Camdessus, deixou claro que o fechamento de um acordo com o Brasil dependeria do retorno das negociações com os bancos. A situação foi bem sintetizada pelo Estado de São Paulo:

"O que se tem portanto é uma cascata de pressões. Os bancos norte-americanos
pressionaram ao mesmo tempo seu governo e o FMI; o subsecretário do Tesouro,
David Mulford, pressionou o FMI e o governo brasileiro; Michel Camdessus
finalmente jogou seu peso sobre o Brasil. Essa cascata reproduz o equilíbrio de
forças que há dentro do FMI: o diretor-gerente limitou-se a implementar uma

\footnotetext{
${ }^{376}$ OESP, "Carta ao FMI já está pronta”, 29 de agosto de 1990, p. 34.

377 OESP, "País volta a falar com o Comitê", 29 de agosto de 1990, p. 34.

${ }^{378}$ FSP, "Bancos credores fazem pressões e forçam mudanças do Fundo", 22 de setembro de 1990, p. C-4. Ver também OESP, "Declarações de Mulford não alteram negociação", 19 de setembro de 1990, p. 39. Argumentase que na viagem anterior de Mulford ao Brasil, em julho, não havia sido tratada a vinculação entre novos empréstimos do FMI e o pagamento dos atrasados aos bancos privados.
} 
decisão que corresponde à da maioria dos votos no board executivo, não por acaso composta de norte-americanos",379

À época, Zélia reagiu de maneira peremptória, descartando a possibilidade de o país aceitar "precondições" nas negociações com o Fundo ${ }^{380}$. A equipe econômica mantinha-se impassível, buscando resistir às pressões:

\begin{abstract}
"Nos últimos dias se tem notado um endurecimento de posições no tocante à questão da dívida externa brasileira. Primeiro foi o subsecretário do Tesouro norteamericano quem jogou o peso de sua função - e a maioria dos votos dos Estados Unidos no FMI - para levar o Brasil a acertar desde já suas contas com os bancos privados. Depois foi a vez do direitor-gerente do FMI insistir diplomaticamente na mesma tese, estabelecendo como condição para a apreciação da carta de intenção e do pedido de crédito stand by pelo Brasil o início de negociações sérias e honestamente indicativas da possibilidade de acordo entre credores e devedor. Em seguida coube ao Grupo dos Sete fazer ver ao Brasil que era necessário negociar com os bancos privados. A rodada da parte de lá se encerrou com o secretário do Tesouro dos Estados Unidos insistindo na mesma tecla. O governo brasileiro a tudo reage com o sorriso da ministra Zélia Cardoso de Mello"381.
\end{abstract}

O mal-estar entre a equipe econômica brasileira e a comunidade financeira internacional ficava escancarado. Em outubro, portanto, quando o Brasil apresentou sua proposta para a renegociação e o pagamento da dívida - de caráter "ousado e imaginativo" no entendimento editorial da Folha de São Paulo - a reação dos bancos credores foi de intransigência e inflexibilidade. O texto apontava o agravamento da crise do Golfo como um elemento de limitação à já estreita margem de manobra das autoridades brasileiras e exortava, tanto aos representantes do governo Collor quanto aos banqueiros internacionais, "o máximo de serenidade e equilíbrio" para que as negociações chegassem a bom termo ${ }^{382}$. Na coluna ao lado, assinada por Fernando Henrique Cardoso, a proposta brasileira era novamente elogiada como "inovadora e ambiciosa", que deveria servir de base para conversas positivas para o interesse nacional. O ponto levantado pelo senador, contudo, era o de que as negociações somente seriam benéficas se houvesse firmeza e, sobretudo, coesão por parte do Brasil. "No governo anterior dois ministros foram 'fritados' enquanto negociavam a dívida lá fora. Evitemos repetir o mesmo desatino (...). [O] decoro político (...) exige que, neste momento, haja sustentação de uma equipe que se dispôs a falar com clareza e fazer aos credores propostas realizáveis pelo país"383.

\footnotetext{
379 OESP, “As pressões do FMI", 22 de setembro de 1990, p. 3.

${ }^{380}$ FSP, “Zélia descarta aceitar precondições do FMI”, 22 de setembro de 1990, p. C-4.

381 OESP, "Posições cada dia mais duras", 25 de setembro de 1990, p. 3.

382 "Serenidade e equilíbrio", FSP, 18 de outubro de 1990, p. A-2.

${ }^{383}$ Cardoso, Fernando Henrique. "A coesão necessária”. FSP, 18 de outubro de 1990, p. A-2.
} 
Todas essas reações devem-se ao fato de que, no dia anterior, 17 de outubro, Zélia havia dado uma entrevista condenando os credores do Brasil pela "fuzilaria desatada" sobre ela. Incomodava-a, em particular, a postura dos bancos norte-americanos: "Eles já não estão muito bem das pernas, estão reduzindo pessoal, têm problemas com os junk bonds e o setor habitacional. Mas eu não tenho nada com isso" ${ }^{\text {384 }}$. Os supostos ataques desferidos contra a ministra vinham de Nova York, onde o embaixador Jório Dauster e o secretário Antônio Kandir tentavam convencer, sem sucesso, os bancos credores a respeito da proposta brasileira. A condição imposta pela comunidade financeira, que só aceitava financiar os juros atrasados se o Brasil tomasse um "empréstimo-ponte" do FMI e do Banco Mundial e se submetesse, portanto, a condicionalidades, não poderia ser aceita pelo governo brasileiro. Ao país não interessava nem submeter-se a monitoramento econômico internacional nem queimar reservas para complementar os empréstimos, somente aceitando o retorno do pagamento dos juros caso o financiamento multilateral viesse no mesmo montante do valor devido. O impasse não tardaria a chegar novamente ${ }^{385}$.

Nas semanas seguintes, os bancos credores trabalharam numa contraproposta ao governo brasileiro. O Brasil mantinha sua recusa em efetuar pagamentos de juros com recursos de suas reservas cambiais antes da conclusão do acordo, com um agravante: tramitava, no senado, o Projeto de Resolução do Senado $n^{\circ} 55$, apresentado por Fernando Henrique Cardoso no dia 25 de outubro, de acordo com o qual o Brasil não poderia acertar os atrasados com os bancos privados sem acordo prévio. Com o impasse adicional no legislativo, as negociações entraram em suspensão pelo resto do ano de 1990, o que contribuiu para o posterior desgaste da equipe econômica. O agravamento do quadro econômico - que obrigou o governo a lançar um novo plano anti-inflacionário no início de 1991 - também impedia que as conversas com os credores chegasse a um bom termo, mantidas as premissas da ministra de não negociar sem condições objetivas de pagamento.

Em fins de janeiro de 1991, o governo dos EUA voltou a advertir o Brasil sobre a "grave situação" de isolamento decorrente da falta de progresso nas negociações com os bancos credores. O impasse nas conversações, que já se arrastava por meses, levara Mulford a convocar o embaixador brasileiro no país, Marcílio Marques Moreira, para adverti-lo sobre as consequências da falta de cooperação por parte do governo brasileiro. Na conversa, sugeriu que o governo Collor havia se colocado, por suas próprias ações, "fora do radar" da comunidade financeira internacional.

\footnotetext{
${ }^{384}$ FSP, "Zélia diz que é alvo de uma trama orquestrada pelos bancos credores", 17 de outubro de 1990, p. B-1.

${ }^{385}$ FSP, "Bancos rejeitam financiar todos os atrasados", 17 de outubro de 1990, p. B-4.
} 
Por isso mesmo, a queda do time de Zélia era uma questão de tempo. Houve pressões de políticos, empresários e de credores internacionais para derrubar a ministra, que já havia colocado seu cargo à disposição de Collor desde janeiro, tendo sido mantida por determinação do presidente. O que precipitou a demissão foi, na avaliação do Delfim Netto (à época aliado de Collor, no PDS), uma série de brigas desnecessárias em horas erradas. “Ao brigar com os credores internacionais, com os empresários, com os sindicatos, ao mesmo tempo em que a inflação está descontrolada, Zélia colocou Collor em uma arapuca”, ponderou o deputado.

Em 21 de março de 1991, o embaixador em Washington, Marcílio Marques Moreira, envia telegrama secreto para o $\mathrm{MRE}^{386}$ relatando que havia mantido várias conversações telefônicas com o subsecretário Mulford, além de contato permanente com o Presidente do BID, Enrique Iglesias, com o diretor-executivo do Brasil naquela instituição, Pedro Malan, e com o embaixador Jório Dauster "a fim de assegurar ação concertada visando a superar o veto dos países do G-7 à aprovação pela diretoria do BID de projetos de empréstimos ao Brasil”. No curso daquela manhã, o "Committee of the Whole", composto por todos os diretores do Banco, aprovou por unanimidade a concessão de empréstimo para o setor de Ciência e Tecnologia, no montante de US\$ 102 milhões. Contudo, no momento da verificação do preenchimento de todos os pré-requisitos para encaminhamento do assunto à diretoria plena, o departamento legal do BID registrou que o Brasil encontrava-se em atraso de mais de trinta dias quanto aos pagamentos relativos a dois empréstimos, "o que automaticamente desqualifica o país para receber a aprovação formal que se vislumbrava como certa". Confrontados com essa realidade, Iglesias e Malan acordaram em anunciar a aprovação do projeto pelo comitê pleno sem referência à falta de formalização do que fora decidido.

A última briga "heroica" da ministra ocorreu em abril, diante de negociações travadas com credores privados a respeito do pagamento de atrasados que somavam US\$ 8 bilhões. $\mathrm{O}$ contexto mais amplo era o da interrupção dos pagamentos de juros aos bancos, ainda no governo Sarney, desde julho de 1989. Collor, desde a posse, decidira por não recomeçar a quitação dos juros alegando que seria necessário um acordo "amplo e definitivo" para a dívida. A despeito de pressões por parte dos governos credores, em particular dos Estados Unidos, a conversa somente foi retomada com os bancos em outubro de 1990 e se arrastou por mais seis meses, sem qualquer tipo de acordo. Em abril, com uma proposta consolidada para o

\footnotetext{
${ }^{386}$ BRASEMB Washington para EXTERIORES, 21/03/91
} 
pagamento dos atrasados ${ }^{387}$, o embaixador Jório Dauster - negociador oficial do Brasil - viu seus esforços em risco em decorrência da negativa de alguns bancos credores em aceitar os termos do governo brasileiro. Seria necessária, para o acordo, a aceitação unânime dos 22 bancos membros do Comitê Assessor, grupo composto pelos principais credores privados do Brasil.

Enquanto Dauster tentava persuadir os banqueiros em Nova York, Zélia chegava a Nagóia, no Japão, para a 32ª reunião do BID. Um grande empréstimo multilateral ao Brasil, de US\$ 350 milhões de dólares, destinados ao Ministério da Ação Social e prefeituras para obras de saneamento básico, havia acabado de ser embargado por pressão do G-7, especialmente dos Estados Unidos. De acordo com o governo brasileiro, o argumento técnico de que o Brasil não teria condições de honrar os créditos foi uma maneira de pressionar o país a fechar o acordo com os bancos credores privados em termos desfavoráveis. O cancelamento do empréstimo suscitou reações imediatas no governo. O chanceler Rezek, em viagem a Londres, atacou a decisão - associada, segundo ele próprio, ao sub-secretário do Tesouro norte-americano, David Mulford - chamando-a de "um gesto de brutal infelicidade", que degenera a credibilidade de um foro multilateral como o BID e "destrói o bom senso, agride o bom senso que deve preservar as relações internacionais" $" 388$.

Zélia já chegou ao Japão obstinada em criticar a negativa do BID. O tom da ministra em seu discurso seria compatível com o dissabor do governo em ver-lhe negados empréstimos para políticas sociais. Na noite que precedeu a fala de Zélia, houve uma tentativa, por parte de outras delegações nacionais, de demovê-la de utilizar uma retórica excessivamente crítica contra os EUA ${ }^{389}$. Não adiantou, e o recado foi desferido, no dia seguinte, com toda a força:

\footnotetext{
"Reconhecemos a necessidade de correção dos rumos de nossas economias e estamos implementando, apesar dos sacrifícios, reformas profundas de cunho liberalizante, em plena vigência da democracia. Necessitamos uma economia internacional que seja suporte e não entrave ao nosso desenvolvimento (...) e um apoio claro e sem condicionantes espúrios (...) a nossos planos de estabilização e a nossos projetos de desenvolvimento" 390
}

Com relação às exigências de que o governo brasileiro cedesse aos credores privados para que os empréstimos fossem liberados, a ministra também foi bastante dura. "Não tem

\footnotetext{
${ }^{387}$ A proposta previa o pagamento imediato de US\$ 1 bilhão, o parcelamento, até o fim do ano de 1991, de mais US\$ 1 bilhão, e os US\$ 6 bilhões restantes seriam transformados em bônus de dez anos (FSP, 6 de abril de 1991, p. 10).

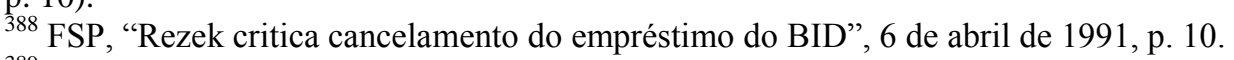

${ }^{389}$ Sabino, 1991, p. 218-219.

${ }^{390}$ FSP, 8 de abril de 1991, p. 10.
} 
qualquer base econômica o pedido de adiamento feito por alguns países. Na realidade, tal pedido visa estabelecer vinculação nova, ilegítima $e$ inaceitável entre a consideração de projetos de investimento pela diretoria do BID e as negociações com bancos privados", sustentou Zélia em seu discurso $^{391}$.

Imediatamente após o pronunciamento da ministra da Economia, Mulford frisou em entrevista coletiva que os EUA não estavam castigando o Brasil, nem pressionando para o país tomar posição com relação aos credores privados. Justificou o atraso na liberação da verba em função de problemas "técnicos e jurídicos" ligados à necessidade de uma licitação internacional para a aprovação de financiamentos, acrescentando que já havia um clima de desconfiança, por parte de outros países credores, com relação à ausência de progresso nas negociações brasileiras com os bancos internacionais. "Apoiamos o governo e o plano do presidente Collor. Queremos que o país melhore sua situação econômica, mas acreditamos ser essencial restabelecer boas relações com a comunidade financeira"392.

A incapacidade da ministra da Economia em nutrir esse relacionamento positivo com os credores, seja em função de suas convicções ou responsabilidades, levou à sua demissão, no dia 8 de maio de 1991. A data ficou registrada como o fim de um capítulo do governo Collor - a "fase heroica", nos termos de Bresser-Pereira -, período no qual os formuladores econômicos, e Zélia em particular, haviam partido de diagnósticos corretos sobre a economia brasileira - a crise fiscal do Estado e o esgotamento do modelo nacional-desenvolvimentista para tentar firmemente reduzir a dívida pública externa e enxugar o tamanho do Estado, por meio da liberalização do comércio internacional. Não se tratava, ao contrário do que se costuma dizer, do estabelecimento de uma lógica de laissez-faire mas, ao contrário, do saneamento e da reforma do Estado para que ele "pudesse voltar a intervir eficientemente, embora subsidiariamente ao mercado, em novos setores: política industrial e tecnológica, política social, política do meio ambiente" ${ }^{\text {393 }}$. Praticamente todos os assessores econômicos do primeiro escalão demitiram-se com Zélia, dando até mesmo a sensação de o Brasil estar vivendo uma espécie de parlamentarismo. A queda da - até então - mulher mais poderosa da República representou, portanto, uma inflexão no governo - que, de tão profunda, marcará um novo período da política externa brasileira.

\subsection{A autonomia em marcha: integração regional}

\footnotetext{
${ }^{391}$ Idem, grifo nosso.

${ }^{392}$ FSP, 8 de abril de 1991, p. 10.

${ }^{393}$ Bresser-Pereira, 1991, pp. 9-10.
} 
Um dos temas centrais levantados por Collor durante a campanha, e que ganhou especial atenção ao longo de todo seu mandato, foi a integração do Cone Sul. Do "impressionismo" das primeiras propostas aventadas pelo presidente ainda na corrida eleitoral (como eleições diretas para o Parlamento Latino como panaceia para as questões integracionistas), a ideia de estabelecer-se um mercado comum entre Brasil e Argentina, extensível aos demais países da América Latina (com prioridade, naturalmente, aos vizinhos platinos), ganhou contornos concretos e orientou, em algum sentido, os processos de abertura comercial e "integração competitiva" à economia mundial ${ }^{394}$. Em parte, as derrotas no front da dívida eram compensadas por importantes avanços na integração sub-regional - conduzida prioritariamente pelo Itamaraty e pelo presidente, mas com a participação da equipe econômica.

Embora as bases conceituais já tivessem sido estabelecidas ao longo do governo Sarney, formuladas pelas chancelarias brasileira e argentina e conduzidas, no plano diplomático, pelos presidentes dos dois países, a conjuntura internacional que se abria no alvorecer da década de 1990 apresentava elementos novos e potenciais oportunidades. Em primeiro lugar, como afirma Veiga, a formação de espaços econômicos supranacionais - a regionalização - tendia a se consolidar como a forma dominante de gestão da interdependência. Acordos preferenciais de comércio, zonas de livres comércio e uniões aduaneiras estabeleceram-se em todos os continentes (com graus variados de efetividade) como alternativa ao multilateralismo comercial, que vinha se desgastando na esteira do acirramento dos conflitos bilaterais de comércio. As dificuldades observadas nos extenuantes debates da Rodada Uruguai do GATT eram, talvez, o sintoma mais claro desse processo. Com a integração regional, evitavam-se "os inconvenientes do multilateralismo sem, no entanto, se impedir o funcionamento das instâncias multilaterais", podendo inclusive estabelecer-se como fenômenos complementares no horizonte: ao acelerar os processos de harmonização de legislações e políticas nacionais e garantir mecanismos de enforcement mais focalizados, a regionalização poderia funcionar como um fator de aceleração da liberalização multilateral ${ }^{395}$.

Em segundo lugar, o início da nova década marcava a consolidação de dois grandes eixos que comandavam a estruturação de espaços supranacionais e a difusão da regionalização. No eixo OCDE, no interior do qual os fluxos de comércio, investimento e tecnologia haviam se intensificado nos dez anos anteriores, ocorria um processo de

\footnotetext{
${ }^{394}$ Sallum Jr., 2010.

${ }^{395}$ Veiga, Pedro da Motta. "Sete hipóteses...” p. 20
} 
harmonização de políticas em direção ao estabelecimento de uma zona de livre comércio e investimento - que poderia, eventualmente, incluir os novos países industrializados da Ásia. O outro eixo dizia respeito aos três grandes pólos da economia mundial - CEE, América do Norte e Japão - e a redefinição das relações entre centro (núcleo econômico do pólo) e suas próprias periferias. Ao mesmo tempo, a perda de dinamismo dos fluxos Sul-Sul deixava as economias vulneráveis com poucas alternativas, cabendo-lhes gravitar estruturalmente em torno dos núcleos econômicos consolidados. Uma das consequências desse fenômeno é que cada um dos pólos passa a envolver não somente países com razoável grau de homogeneidade quanto a níveis de desenvolvimento, renda e capacidade de regulação macroeconômica, mas outros Estados mais frágeis, heterogêneos e menos estruturados.

No caso da América Latina, as transformações recentes no relacionamento dos Estados Unidos com o hemisfério, incentivadas pela chegada de George Bush ao poder, em 1989, colocaram o debate sobre integração (e seus modelos possíveis) como prioridade nas agendas de política econômica externa dos países da região. As negociações em torno do acordo de livre comércio entre os Estados Unidos e o México, em pauta desde o início dos novos governos em ambos os países - que tomaram posse com 50 dias de diferença -, acentuaram a necessidade de as maiores economias latino-americanas, dentre as quais Brasil e Argentina, buscarem alternativas à "influência assimétrica" que sempre pautou o relacionamento com os EUA. Caso contrário, já se antevia que a solução oferecida pela nação hegemônica era a reprodução de um receituário liberal do Consenso de Washington que contribuiria muito pouco para a redução das assimetrias entre economias centrais e periféricas no hemisfério.

Terceiro: os recentes desenvolvimentos na estrutura econômica global sugeriam que se alterassem de maneira expressiva os condicionantes externos ao processo de integração argentino-brasileiro, sobretudo quando comparados à situação vigente quando da assinatura dos acordos bilaterais de integração econômica. Nas palavras de Roberto Lavagna,

\footnotetext{
"Não estavam em curso nem o acordo EUA-Canadá, nem o EUA-México, nem o aprofundamento comunitário de 1992, nem a ainda hoje difusa associação comercial do Sudeste Asiático. Tampouco estavam em marcha as conversações multilaterais do Acordo Geral de Tarifas e Comércio (Gatt). Obviamente, também não se previa o ocorrido no Leste Europeu" ${ }^{396}$.
}

As circunstâncias domésticas também mudaram drasticamente em função de alterações políticas - a eleição de Carlos Menem e de Fernando Collor de Mello, em 1989 - e

${ }^{396}$ Lavagna, 1991, p. 34. 
do agravamento do quadro macroeconômico em ambos os países. Em adição a isso, as prioridades econômicas nos dois vizinhos convergiam para duas questões de extrema urgência: a estabilização da moeda, em primeiro lugar, bem como o aprofundamento da liberalização comercial e da abertura econômica com relação ao mundo. A rigor, a nova correlação de forças externas e domésticas tendia a reduzir a importância do processo integracionista per se, ou ao menos minimizar os incentivos à integração sub-regional como pré-condição à revitalização econômica de Argentina e Brasil. Ficava claro, assim, que o modelo de integração do Cone Sul propugnado pelos dois novos presidentes seria necessariamente mais "aberto ao mundo" em termos comerciais do que o esquema mentalizado meia década antes. Em outras palavras, para Pedro da Motta Veiga,

\footnotetext{
"o requisito de compatibilidade em relação ao movimento de liberalização externa [das economias] se impõe crescentemente ao processo de integração, mesmo se as diferenças no ritmo e no grau de abertura das duas grandes economias da sub-região sugerem que, neste quadro, dificilmente se desenvolverão interesses econômicos solidários dos dois lados da fronteira" ${ }^{\prime 397}$.
}

De fato, nos primeiros movimentos do governo Collor testemunhou-se uma deterioração das relações bilaterais com a Argentina, notadamente no campo econômico. Um mês após a posse do novo presidente, o abalo provocado pelo plano de estabilização econômica e a contínua crise inflacionária no país vizinho traziam perspectivas sombrias para o fluxo comercial. Com base nos dados de janeiro e fevereiro de 1990 (antes, portanto, do choque do Plano Collor), o intercâmbio bilateral estava projetado para algo em torno de US\$ 780 milhões, decréscimo sensível em relação aos US\$ 2 bilhões que o comércio BrasilArgentina atingiu em 1989. Ademais, dos 24 protocolos de integração mantidos desde 1986, grande parte não havia ultrapassado a etapa inicial, burocrática, do estabelecimento de grupos de trabalho e comissões bilaterais ${ }^{398}$. Para agravar a situação, o governo brasileiro foi informado de que o embaixador Héctor Subiza, em Brasília desde 1986, deixaria o cargo. Entusiasta da aproximação brasileiro-argentina, Subiza seria substituído por José Manuel de la Sota, importante político peronista mas sem qualquer vínculo com o Brasil - e, ainda mais

\footnotetext{
${ }^{397}$ Veiga, 1991, p. 13.

${ }^{398}$ FSP, "Protocolos não saem do papel”, 6 de julho de 1990, p. A-4. De acordo com a matéria, os protocolos que tiveram maior evolução foram aqueles relativos a alimentos $(2,3,22)$, principalmente por questões conjunturais. As metas do Protocolo no. 1, sobre bens de capital, não foram cumpridas - da previsão de um volume de negócios no valor de US\$ 400 milhões, em 1988, cumpriu-se US\$ 62 milhões. O protocolo no. 21, sobre indústria automobilística, representava a situação mais crítica: dos dez mil carros e US\$150 milhões em autopeças previstos, em 1989 - meta ampliada para 20 mil carros em 1990 - nenhum carro ou peça havia sido comercializado até a visita de Collor a Buenos Aires, em julho.
} 
grave, sem qualquer instrução de Menem para aprofundar ou mesmo preservar a integração econômica entre os dois países ${ }^{399}$.

\subsubsection{O "choque sistêmico": a Iniciativa para as Américas}

Foi necessário um choque externo para que a política integracionista de ambos os países fosse alterada. O lançamento da Iniciativa para as Américas, em fins de junho de 1990, representou esse novo elemento estrutural nas relações econômicas internacionais de Brasil e Argentina. Anteriormente ao Plano Bush, os países encontravam-se diante do reconhecimento da marginalização da América Latina - representada, de maneira visível, pelo processo de unificação europeia. O resgate de uma Alemanha unida e as transformações do Leste Europeu jogaram por terra, no entendimento de Reis Velloso, "a ilusão latino-americana" de uma relação especial com a CEE. Diante dessa realidade, o Brasil poderia manter uma postura "ecumênica" diante dos três grandes blocos que se estruturavam - Europa, América do Norte ou Ásia -, buscando desenvolver alianças formais com países e empresas multinacionais dentro de cada um dos núcleos dinâmicos dos pólos econômicos (por meio de tratados de livre comércio) ou, alternativamente, estabelecer arranjos informais, de efeito mais limitado, mas que "nos permitissem maior relacionamento de comércio, tecnologia, investimentos e financiamentos" com os agentes econômicos dentro dos mesmos blocos ${ }^{400}$.

A proposta norte-americana, conquanto embrionária e suscetível a desconfianças de saída por parte do Brasil ${ }^{401}$, oferecia uma oportunidade de estabelecer-se, no longo prazo, uma zona de livre comércio pan-americana. Isso interessava aos Estados Unidos, por diversas razões: de headache zone que a América Latina representava, no transcurso dos anos 1980 (em torno das temáticas de drogas, dívida e democracia), almejava-se restabelecer vínculos positivos com o hemisfério, a partir da importância do comércio e dos investimentos norteamericanos na região; o declínio econômico da América Latina, em decorrência da crise da dívida, havia sido responsável pela expressiva redução das exportações norte-americanas para a região e pela elevação do desemprego interno. Além disso, a continuidade geográfica do hemisfério e a penetração cultural norte-americana sobre seus vizinhos ao sul em termos de cultura, língua ou religião (associada a traços culturais ocidentais), tornava a região

\footnotetext{
${ }^{399}$ FSP, "Relação econômica com Argentina está abalada", 16 de abril de 1990, p. A-5.

${ }^{400}$ Reis Velloso, João Paulo dos. P. 9-10

${ }^{401}$ A relação do Brasil com os Estados Unidos, mesmo em tempos de bonança, apresenta um importante elemento de desconfiança. Isso se vê claramente - e em paralelo ao Plano Bush de 1990 - na maneira como o governo Jânio Quadros endereçou a Aliança para o Progresso, plano do presidente John Kennedy para o aprofundamento e desenvolvimento das relações norte-americanas com a América Latina.
} 
particularmente atrativa na virada da década. Finalmente, como destaca Thomas Carothers, a América Latina tornava-se, paulatinamente, "a única macrorregião sobre a qual os Estados Unidos mantêm bastante influência" ${ }^{402}$. Em síntese, comentam Thorstensen e Bresser-Pereira,

\begin{abstract}
“terminada a Guerra Fria e a hegemonia econômica dos Estados Unidos, há uma perspectiva de enfraquecimento do GATT e o fortalecimento dos blocos regionais. Entre eles, os Estados Unidos, embora ainda inconformados com a perda da hegemonia, e desejando muito naturalmente manter seu comércio aberto com todo o mundo, não terão outra alternativa senão dar força ao Bloco dos Américas. Este bloco será de grande utilidade para os Estados Unidos não apenas para exercer pressão e barganhar posições no contexto internacional, mas também para assegurar um espaço preferencial para suas exportações e investimentos"
\end{abstract}

Não parece coincidência, portanto, que a formulação de Bush traga elementos da Aliança para o Progresso, de Kennedy, também motivada pelo desejo de restabelecer relações positivas com o hemisfério após um longo período de desgaste:

\begin{abstract}
"Nos últimos doze meses, cada um de nós, do homem na Casa Branca ao homem nas ruas, fascinou-se com as expressivas mudanças, as mudanças positivas, ocorrendo ao redor do mundo. A liberdade vem obtendo grandes conquistas não somente no Leste Europeu mas bem aqui nas Américas; testemunhamos o ressurgimento do estado democrático, uma maré crescente de democracia, nunca antes vista na história de nosso querido hemisfério (...). As transformações políticas (...) têm seu paralelo na esfera econômica. Ao redor da região, nações estão se distanciando das políticas econômicas estatistas que coíbem o crescimento e agora voltam-se ao poder do mercado para ajudar o hemisfério a concretizar seu pleno potencial para o progresso",404
\end{abstract}

A Iniciativa para as Américas organizava-se em torno de três vertentes. A primeira delas dizia respeito ao comércio. A liberalização comercial, como destaca Azambuja, é a proposta de mais amplo alcance do Plano Bush e contempla estreita colaboração com os vizinhos latino-americanos com o objetivo duplo de firmar um acordo hemisférico de livre comércio, por um lado, e assegurar o êxito da Rodada Uruguai do GATT, por outro. Como condição à concretização das propostas norte-americanas, impunha-se aos países da região a adoção de medidas econômicas alinhadas com a ideia do Consenso de Washington. No limite, desejava-se criar um sentido de identidade hemisférica, fomentando um amplo regime de livre comércio através do rompimento das barreiras alfandegárias, as quais fizeram com que os fluxos comerciais da região não acompanhassem o ritmo da expansão e do comércio mundial

\footnotetext{
402 Citado em Azambuja, 1991, p. 26.

403 Thorstensen, Vera e Bresser-Pereira, Luiz Carlos.”Do Mercosul à Integração Americana”. Política Externa, vol. 1 , no. 3, 1992.

${ }^{404}$ Bush, George. "Remarks Announcing the Enterprise for the Americas Initiative", 27 de junho de 1990. Disponível em http://www.presidency.ucsb.edu/ws/?pid=18644 . Acesso em 12/09/2014.
} 
nos anos 1980. De outro lado, pretendia-se viabilizar, no contexto do comércio multilateral, as propostas de aprofundamento das reduções tarifárias de produtos específicos de interesse dos países da América Latina e do Caribe, como forma de reintegrá-los plenamente no sistema $\mathrm{GATT}^{405}$.

A segunda vertente dizia respeito a investimentos. Visava-se encorajar o aumento dos fluxos de capital e a participação do setor privado nas economias latino-americanas, ampliando seu potencial de atração e promoção de investimentos. O governo norte-americano dispunha-se a trabalhar em prol de novos programas de empréstimos setoriais no BID, destinados aos países em processo de ajustamento econômico - com aval ou empréstimos do Fundo Monetário Internacional e do Banco Mundial - e que estejam realizando esforços de privatização e liberalização dos investimentos no marco do Consenso de Washington. Paralelamente, os Estados Unidos propuseram a criação de um fundo multilateral de investimento, com duração de cinco anos e administrado pelo BID, para prover ajuda financeira de até US\$ 300 milhões ao ano às economias comprometidas com as reformas liberalizantes $^{406}$.

A última vertente está ligada ao tema mais sensível aos latino-americanos, a dívida externa. A ideia do Plano Bush era oferecer novas formas de tratar o problema da dívida, reduzindo seu impacto negativo sobre as economias do hemisfério, mas com enfoque distinto (e complementar) ao do Plano Brady: enquanto este se propunha a facilitar as condições de renegociação da dívida junto aos credores privados, a Iniciativa para as Américas atuava no auxílio às negociações de alívio da dívida oficial de governo a governo, com vistas a eventuais reduções ${ }^{407}$.

\subsubsection{Divergências e oportunidades na integração sub-regional}

O lançamento da Iniciativa para as Américas fez com que Brasil e Argentina acelerassem o processo de integração. Tratou-se do incentivo externo necessário para que, especialmente do lado argentino, as negociações voltassem a caminhar. Em sua visita oficial a Buenos Aires, entre 6 e 7 de julho de 1990, Collor e sua comitiva - composta pelos ministros Francisco Rezek, Ozires Silva e Zélia Cardoso de Mello - reuniram-se duas vezes com o

\footnotetext{
${ }^{405}$ Reis, Carlos Nelson dos; Fischer, Sérgio; Campos, Silvia Horst. "Programa Iniciativa para as Américas (Plano Bush): algumas considerações”. Indicadores Econômicos FEE, vol. 18, no. 2, 1990.

${ }^{406}$ A meta norte-americana é contribuir anualmente para esse fundo com US\$ 100 milhões, tentando obter contribuições iguais da Europa e do Japão.

${ }^{407}$ Reis et al., 1990, p. 18.
} 
presidente Menem, debruçando-se sobre os temas de integração. O desejo do mandatário argentino era antecipar a formação do Mercado Comum para 1992, numa simbólica celebração dos 500 anos do descobrimento da América. Para as chancelarias dos dois países, a meta era um pouco menos ambiciosa: $1^{\circ}$ de janeiro de $1995^{408}$. Ainda assim, tratava-se de processo muito mais veloz do que originalmente vislumbrado no Tratado de Cooperação de 29 de novembro de 1988, que lançava o projeto de mercado comum em duas etapas e com uma meta temporal fixada em dez anos ${ }^{409}$.

A Ata de Buenos Aires, assinada no encontro, representava uma importante mudança na metodologia da integração sub-regional. O processo inaugurado em 1986 orientava-se pela lógica dos "projetos integrados", que buscavam acordos de complementação comercial e industrial, não necessariamente generalizáveis, dentro de ramos produtivos. Tratava-se, nas palavras de Lavagna, de processo "gradual, flexível, progressivo e profundo"410 . O de 1990, por sua vez, embora conservasse o sentido da integração, alterava sua sequência temporal e, potencialmente, sua resultante final. A questão levantada por Lavagna é por que a Argentina país relativamente mais débil em termos de estrutura econômica - decidiu ser a gestora dessa mudança de regras de operação do projeto integrador. O autor prossegue:

\begin{abstract}
"A resposta deve ser buscada no fato de que a Argentina já não acredita no caráter estratégico de seu acordo com o Brasil com a mesma intensidade que o fazia em 1986. De fato, hoje a Argentina está pensando um esquema de política econômica marcadamente 'mais aberto' que o do Brasil. Sua prioridade é uma abertura generalizada, mais que uma abertura negociada, daí a aparente desimportância de acordar mecanismos generalizados com o Brasil quando, ao mesmo tempo, os efeitos destes são diluídos pela política geral em matéria de estrutura produtiva, indústria e comércio exterior", ${ }^{\prime 411}$.
\end{abstract}

O que justificava tal ansiedade para concluir o processo integracionista? Há, ao menos, duas respostas possíveis. Do lado brasileiro, a intenção era fortalecer a integração como forma de consolidar as duas economias e aumentar, por conseguinte, a margem de manobra diante do renovado interesse do governo Bush em engajar-se, em termos comerciais, com a América Latina. Sabia-se bem, como recorda Azambuja (então Secretário-Geral de Política Exterior do MRE), que os temas críticos ao Brasil no contexto do Plano Bush foram ofertados de maneira claramente insuficiente: em termos de investimentos, o aporte sugerido de US\$ 300 milhões anuais não bastava a uma região que havia se descapitalizado em nada

\footnotetext{
${ }^{408}$ FSP, “Menem quer antecipar unificação para 1992”, 6 de julho de 1990, p. A-5.

${ }^{409}$ FSP, "Moeda e BC podem ser unificados", 6 de julho de 1990, p. A-5.

${ }^{410}$ Lavagna, Roberto. "Integração Argentina-Brasil: origens, resultados e perspectivas". In: Motta Veiga, Pedro da. Cone Sul: a economia política da integração. Rio de Janeiro: FUNCEX, 1991, p. 49.

${ }^{411}$ Idem, p. 50-1.
} 
menos que US\$ 200 bilhões, entre 1982 e 1990, em consequência de transferências líquidas aos países desenvolvidos; no tocante à dívida, o total de créditos oficiais norte-americanos para com a América Latina representava somente 3\% do total da dívida externa da região, não solucionando, ao menos de maneira direta, o contencioso com os bancos privados; finalmente, com relação ao comércio, os Estados Unidos pareciam pouco interessados em ceder aos interesses brasileiros em temas como eliminação de subsídios agrícolas (como no caso do óleo de soja), revisão de legislação antidumping e redução tarifária aplicada a certos produtos, como têxteis, calçados, etanol e suco de laranja ${ }^{412}$. Fortalecer a frente brasileiro-argentina de forma integrada era a maneira vislumbrada pelo Brasil de aumentar sua capacidade de barganha vis-à-vis os Estados Unidos.

A Argentina, por outro lado, via a Iniciativa como uma janela de oportunidade para que se pudesse levar a bom termo sua integração ao Primeiro Mundo, conforme a doutrina do realismo periférico que guiava as relações exteriores do país desde a chegada de Menem ao poder. Ao contrário do Brasil, que condicionava a aproximação às potências industrializadas à necessidade de superar entraves políticos e econômicos domésticos, tratando-a como uma questão de credibilidade internacional acima de tudo, o governo argentino compreendia que os maiores benefícios ao país adviriam não da construção de um bloco integracionista voltado para dentro, mas de um regionalismo aberto, conectado aos centros econômicos. No limite, Menem e sua equipe viam a aproximação com o Brasil como um passo - embora necessário e urgente - para que se pudesse estabelecer, conforme propugnado pelos Estados Unidos, uma zona hemisférica de livre-comércio. Não encaravam a integração regional como um elemento de poder - consideração que orientava os trabalhos, por exemplo, do Itamaraty - mas, sim, de possibilidades comerciais, em linha com a nova orientação da inserção internacional do país, de foco marcadamente econômico. Nesse caso, parece-nos razoável afirmar que a ansiedade argentina estava muito mais relacionada com a janela aberta a seus interesses comerciais - e que poderia ser ocupada por países como México e Chile - do que com a consolidação da integração do Cone Sul em si.

A maneira como setores econômicos e políticos nos dois países endereçavam a questão da integração argentino-brasileira é sintetizada no Quadro 1. Vê-se, por exemplo, o apoio incondicional conferido ao Ministério das Relações Exteriores no Brasil, em oposição ao análogo argentino - que, alinhado aos interesses de seu Ministério da Economia, buscava "diluir" o projeto no contexto do regionalismo aberto e da integração hemisférica. Enquanto

${ }^{412}$ Azambuja, 1991b, p. 28. 
Menem almejava acelerar o processo para não perder as oportunidades abertas pelos Estados Unidos, em linha com os interesses de suas burocracias, Collor aproximava-se do entendimento da diplomacia - a respeito da importância política (além de econômica) do aprofundamento da integração - e distanciava-se da leitura realizada por seu próprio Ministério da Economia, mais cético quanto aos objetivos da parceria. Nas palavras da ministra Zélia, "este era um projeto em que o Presidente acreditava muito e via como um ponto de partida para fortalecer o bloco latino-americano, para que as economias fortalecessem relações comercias (...). Eu tinha uma visão menos otimista, dadas as diferenças entre as economias integrantes do [viria a ser o] Mercosul"413.

Quadro 1 - Síntese das atitudes ante o acordo Argentina-Brasil

\begin{tabular}{|l|l|l|}
\hline $\begin{array}{l}\text { Atitude de setores ou } \\
\text { responsáveis }\end{array}$ & Argentino & Brasileiro \\
\hline Apoio & $\begin{array}{l}\text { - Empresários } \\
\text { - Partidos políticos populares }\end{array}$ & $\begin{array}{l}\text { - MRE } \\
\text { - Partidos políticos populares } \\
\text { - Intelectuais de centro }\end{array}$ \\
\hline $\begin{array}{l}\text { Apoio condicionado a } \\
\text { limitar a automaticidade e } \\
\text { buscar simetrias }\end{array}$ & $\begin{array}{l}\text { - Empresários de setores básicos e } \\
\text { com altas assimetrias }\end{array}$ & $\begin{array}{l}\text { - Empresários de setores } \\
\text { primários e agro-industriais }\end{array}$ \\
\hline $\begin{array}{l}\text { Intenção de "diluir" o } \\
\text { projeto }\end{array}$ & $\begin{array}{l}\text { - Intelectuais de partidos } \\
\text { majoritários (centro) }\end{array}$ & $\begin{array}{l}\text { - Ministério das Relações } \\
\text { Exteriores } \\
\text { - Ministério da Economia } \\
\text { - Forças políticas de centro-direita } \\
\text { - Intelectuais de direita }\end{array}$ \\
\hline $\begin{array}{l}\text { Indiferença ou atitude } \\
\text { passiva }\end{array}$ & & $\begin{array}{l}\text { - Empresários } \\
\text { - Ministério da Economia } \\
\text { - Partidos políticos de centro- } \\
\text { direita } \\
\text { - Sindicatos } \\
\text { - Intelectuais de direita }\end{array}$ \\
\hline
\end{tabular}

Lavagna, 1991, p. 52.

Neste momento, torna-se possível compreender a natureza da aproximação com os Estados Unidos, por parte da administração Collor, e que tipo de efeitos isso poderia trazer à condução do processo de integração. Embora os marcos gerais do projeto inicial de inserção internacional daquele governo estivessem destinados a "desembaraçar" os antigos contenciosos na agenda bilateral com os Estados Unidos, viabilizando o projeto de integração competitiva à economia global, a chancelaria brasileira encontrou no Mercosul um espaço

${ }^{413}$ Cardoso de Mello, Zélia. Entrevista ao autor, 18 de outubro de 2014. 
para a busca de uma atuação internacional autônoma, em que objetivos presidenciais e diplomáticos corresponderam-se por inteiro ${ }^{414}$.

Foi exatamente a determinação dos operadores diplomáticos brasileiros que viabilizou a assinatura, em 26 de março de 1991, do Tratado de Assunção, que deu origem ao Mercado Comum do Sul - somando ao condomínio argentino-brasileiro a participação de Uruguai e Paraguai. Como pontua Flávia de Campos Mello, as motivações entre os dois principais sócios eram distintas, e os próximos passos da integração - com novas interferências sistêmicas - demandariam um esforço ainda maior do Itamaraty para conduzir o processo à sua maneira:

\begin{abstract}
"No próprio momento de gestação do projeto do Mercosul, já era explícita a divergência de posições entre Brasil e Argentina acerca dos objetivos do processo de integração sub-regional. Quando da assinatura da Ata de Buenos Aires e da decisão de cooordenar posições perante o Plano Bush, em 1990, o discurso argentino referiase à 'unidade continental', entendendo o Mercosul como um primeiro passo na integração continental, enquanto o Brasil já enfatizava que sua prioridade consistiria no fortalecimento da unidade sub-regional para mais tarde tornar possível uma eventual negociação hemisférica." 415
\end{abstract}

\title{
4.5. Itamaraty de volta ao centro: Guerra do Golfo e a "crise dos reféns"
}

Em meio a diversas temáticas voltadas a comércio, dívida e integração, a Guerra do Golfo representou um elemento destoante nesta segunda fase do governo, uma vez que exigiu da diplomacia brasileira toda sua habilidade. No limite, tratava-se de uma diferença de lócus da política externa, mas não propriamente de interlocutor, uma vez que os Estados Unidos - e as pressões exercidas por eles, de natureza sistêmica - continuaram sendo o centro da questão. No entanto, ao contrário do processo de integração, em que poderíamos nos amparar na Argentina, ou da questão da dívida, em que os EUA eram um dos elementos centrais, mas não o único, o conflito do Golfo tragou o Brasil para um problema diplomático de grandes proporções, em que nos vimos, inadvertidamente, no campo contrário ao do governo Bush. As concessões, muitas vezes fundamentais para dirimir desconfianças com relação às intenções brasileiras, eram de difícil execução na medida em que o desenrolar das tensões envolvendo o regime de Saddam Hussein colocou cidadãos brasileiros em risco iminente. Por outro lado,

\footnotetext{
${ }^{414}$ Vigevani, Tullo e Veiga, João Paulo Cândia. "Mercosul e os interesses políticos e sociais". São Paulo em Perspectiva, vol. 5, no. 3, 1991, p. 45.

${ }_{415}$ Mello, Flávia de Campos. "Política externa brasileira e os Blocos Internacionais". São Paulo em Perspectiva, vol. 16, no. 1, 2002, pp. 37-43.
} 
não se poderia confrontar os Estados Unidos, como bem lembra Celso Amorim: no contexto da nova estrutura de poder que se erguia dos escombros da Guerra Fria, "a hegemonia norteamericana chegou a tal ponto que os seus objetivos de política externa não só são alcançados (...) como chegam a confundir-se com o próprio conceito de ordem e justiça"416.

A leitura de Amorim é ilustrativa do tipo de constrangimentos estruturais que se impuseram ao Brasil diante do conflito do Golfo, iniciado em agosto de 1990. Estruturais, e não somente conjunturais, porque refletiam a nova distribuição de poder global, bem como a vulnerabilidade brasileira nesse novo quadro. A eclosão da crise no Oriente Médio e suas consequências imediatas, que envolveram o embargo comercial ao Iraque - autorizado pela resolução 661 do Conselho de Segurança, de agosto de 1990 -, colocou o Brasil diante de uma situação duplamente crítica. Se, por um lado, cabia ao governo Collor alinhar-se à inquietação ocidental, condenando a invasão iraquiana do Kuwait nos seus termos mais duros (o que não deixava de relacionar-se aos princípios basilares da política externa brasileira), o prévio relacionamento com o Iraque, que vinha acumulando uma década e meia de prosperidade, não poderia ser rompido subitamente.

Em outros tempos, o pragmatismo comercial teria prevalecido sobre o principismo acrítico, cabendo ao governo brasileiro encontrar um ponto de equilíbrio do equacionamento de suas relações com o Iraque. Entretanto, devido às pressões estruturais que recondicionavam o lugar do Brasil no mundo, sob a batuta da hegemonia norte-americana, coube ao Itamaraty - ao menos no plano retórico - aceder à mesma indignação que se observava entre as lideranças do Primeiro Mundo. A nota de condenação da intervenção militar iraquiana no Kuwait já dava pistas de que o discurso brasileiro havia mudado: "[f]iel às normas do Direito Internacional e da Carta das Nações Unidas, o Brasil condena o uso da força nas controvérsias internacionais e faz veemente apelo para que seja encontrada solução pacífica e imediata para a crise, com base no respeito aos princípios de auto-determinação e não-intervenção" ${ }^{\text {417 }}$. A nota, contudo, foi somente parte de uma história mais longa: ao longo da semana em que se iniciou a crise no Iraque, Rezek hostilizou publicamente o Iraque em diversas entrevistas e manifestações - postura que, na avaliação de alguns diplomatas, foi pouco discreta e muitas vezes exagerada, principalmente em vista dos interesses comerciais que mantínhamos com o regime de Saddam Hussein ${ }^{418}$.

\footnotetext{
${ }^{416}$ Amorim, Celso. "O Brasil e a Ordem Internacional Pós-Golfo". Contexto Internacional, vol. 13, no. 1. 1991, p. 27.

${ }^{417}$ MRE, "Governo brasileiro condena intervenção militar iraquiana no Kuaite”, 2 de agosto de 1990.

${ }^{418}$ Veja, "Namoro abalado", 15 de agosto de 1990, p. 54.
} 
Nos dias seguintes à invasão iraquiana, além da condenação emitida no dia 2 de agosto, o Itamaraty divulgou mais três notas à imprensa, todas em linguagem dura - a despeito das sutilezas próprias ao jargão diplomático. No comunicado de 9 de agosto, o governo brasileiro "[c]onsidera o ato de anexação [do Kuwait, declarado no dia anterior], bem como suas consequências, carentes de qualquer valor legal", reiterando "seu apoio às Resoluções 660 e 661 do Conselho de Segurança das Nações Unidas, esta última consubstanciada pelo Decreto 99.441”, que reconhece “o Estado do Kuaite [sic] e como seu Governo legítimo o do Emir Al-Sabah"419. Uma semana depois, em 15 de agosto, nova nota do MRE, anunciando a suspensão temporária das atividades da embaixada do Brasil no Kuwait, "onde não há, no momento, autoridade oficialmente reconhecida pelo Brasil" "20 . Por fim, no dia 17 de agosto, uma terceira nota declarava o compromisso brasileiro ao bloqueio econômico ao Iraque:

"É desígnio inequívoco do Presidente da República, manifestado de forma institucional e pública, que o Brasil se atenha, de modo rigoroso, aos termos da Resolução 661 (...). Assim, eventual fornecimento ou venda de produtos alimentícios e medicamentos ao Iraque só viria a ocorrer na situação prevista pela Resolução em seu item 3, alínea 'c', isto é, em circunstâncias humanitárias. Por circunstâncias humanitárias entender-se a superveniência de quadro de penúria para a população civil do país e, por extensão, para os estrangeiros eventualmente lá retidos. Isso não ocorre no momento (...)",421.

A retórica adotada pelo MRE no contexto da crise do Golfo, por mais correta que fosse em termos dos princípios defendidos historicamente pela política externa brasileira, poderiam colocar o país em situação duplamente problemática. Em primeiro lugar, a ameaça da explosão dos preços do petróleo no mercado internacional tinha o potencial de arrastar a economia brasileira a condições ainda mais precárias, fazendo desandar as já melancólicas tentativas de remediar o Plano Collor, que havia sido incapaz de debelar, de uma vez por todas, o problema inflacionário. Em segundo lugar, o Brasil teria que romper relações comerciais com aquele que era, no momento do início da crise, o oitavo parceiro comercial, e de quem era o segundo maior exportador. As sanções internacionais poderiam comprometer a balança comercial brasileira.

Com relação à questão do petróleo, havia menos com o que se preocupar. Nos primeiros dias da crise do Golfo, o preço do barril se estabilizara na casa dos US\$26, o que não representava um cenário catastrófico ao suprimento nacional. Ademais, a dependência

\footnotetext{
${ }^{419}$ MRE, "Brasil não reconhece anexação do Kuaite”, 9 de agosto de 1990.

${ }^{420}$ MRE, "Suspensão temporária das atividades da embaixada do Brasil no Kuaite”, 15 de agosto de 1990.

${ }^{421}$ MRE, "Bloqueio econômico ao Iraque - posição do Brasil", 17 de agosto de 1990.
} 
brasileira do combustível iraquiano era bem menor, nos idos de 1990, do que havia sido no início da década anterior ${ }^{422}$, embora ainda houvesse fortes laços de dependência ${ }^{423}$. Na avaliação de Seme Taleb Fares,

\begin{abstract}
"Na ocasião da invasão do Kuwait, o problema do abastecimento de petróleo não era mais tão dramático quanto nos casos anteriores de crises políticas no Oriente Médio. As chances do surgimento de uma nova crise do petróleo eram remotas. Além de o Brasil estar menos dependente do petróleo importado, não faltavam fornecedores alternativos no mercado internacional. O governo brasileiro se sentia, assim, livre para, sem grandes custos à economia do País, se distanciar da posição iraquiana, o que facilitava a execução de uma clivagem desde o início proposta por Fernando Collor/Francisco Rezek em relação às gestões anteriores, em que eram observados 'alinhamentos automáticos' com os fornecedores de petróleo. Os antigos temores das autoridades brasileiras em relação à instabilidade política no Oriente Médio e um eventual corte no fornecimento de petróleo ao País ficaram no passado" ${ }^{424}$
\end{abstract}

A questão nevrálgica na relação com o Iraque, portanto, dizia respeito ao comércio bilateral. Em 1989, o Brasil exportou o expressivo valor de US\$ 342 milhões para o governo de Saddam Hussein ${ }^{425}$ - cifra que superava as vendas para países como México ou Portugal. De automóveis a frango congelado, de armamentos a madeira compensada, empresas brasileiras haviam encontrado no Iraque um mercado formidável. Mesmo que as trocas tivessem perdido intensidade ao longo da década de 1980, sobretudo após sucessivos calotes dados pelo governo iraquiano a empresas militares como a Avibrás e a Engesa, Saddam Hussein ainda era um parceiro importante. Nos primeiros dias que sucederam à crise, grandes empresas brasileiras - como a Sadia ou a Volvo do Brasil - e até mesmo companhias menores, como a Intermares, que exportava café solúvel e água mineral para o Kuwait, somaram incontáveis prejuízos, o que contribuiu para as pressões políticas que demandavam uma posição mais branda do governo Collor ${ }^{426}$.

\footnotetext{
422 "Em 1984/1985, o Brasil produzia cerca de 60\% do petróleo que consumia, enquanto que em 1978 esse número representava apenas $10 \%$ do total. Além disso, o preço do petróleo importado, embora continuasse representando um ônus muito grande ao País, estava diminuindo rapidamente. De 1985 para 1986, os preços do barril de petróleo decaíram em quase 55\%, dos US\$ 28 para US\$ 13 , se estabilizando nesse valor nos anos posteriores, em decorrência, principalmente, do excesso de oferta. Por esses motivos, o peso relativo do petróleo no total das importações do Brasil decaiu do patamar de mais de 50\% no início da década de 1980 para pouco mais de $20 \%$ no fim da década. Em valores, os dispêndios com o petróleo importado em 1988 representavam cerca de 1/3 daquele do início da década". Fares, Seme Taleb. "O Pragmatismo do Petróleo: as relações entre o Brasil e o Iraque". Revista Brasileira de Política Internacional, vol. 50, no. 2, 2007, p. 141.

${ }^{423}$ Nas palavras do chanceler Francisco Rezek, em carta enviada à ministra da Economia, Zélia Cardoso de Mello (MRE, GTNR-DOC/DOP-1, 25/04/1990, secreto), "esse relacionamento privilegiado [entre Brasil e Iraque] tornou o Iraque o maior e mais seguro supridor individual de petróleo do Brasil, tendo sido responsável, em 1989, pelo fornecimento de 252 mil bpd [barris por dia], equivalentes a $43 \%$ das importações brasileiras de óleo cru".

${ }^{424}$ Fares, 2007, p. 142.

${ }^{425}$ MDIC, 2012.

${ }^{426}$ Veja, "Namoro...", p. 53.
} 
O caso mais crítico, contudo, dizia respeito às empresas que mantinham funcionários nacionais em solo iraquiano, como a construtora Mendes Júnior, de Belo Horizonte ${ }^{427}$. Com 234 brasileiros, localizados em dois acampamentos próximos à fronteira do Kuwait e da Jordânia, a empreiteira viu-se numa situação delicada, já que uma das primeiras decisões de Saddam Hussein foi impedir a saída de estrangeiros do país, à exceção dos diplomatas e daqueles cidadãos que já possuíssem visto de saída ${ }^{428}$. No caso específico da empresa brasileira, o Iraque condicionava a concessão de vistos de saída a seus funcionários à resolução de um contencioso comercial de longa data, que se acumulava desde meados da década anterior e não tinha grandes perspectivas de encaminhamento, especialmente face à conduta do governo brasileiro.

A situação entre a Mendes Júnior e o governo iraquiano era especialmente delicada. Embora a guerra Irã-Iraque houvesse, inicialmente, criado oportunidades para a exportação de serviços brasileiros ao governo de Saddam Hussein, sobretudo no campo de construção civil, o aprofundamento do conflito gerou sérias perdas comerciais às empresas brasileiras. A alegação da Mendes era a de que o Iraque, tendo concentrado seus recursos para atender os encargos de guerra, deixara de realizar pagamentos à empresa, ao mesmo tempo em que agregava componentes de custos adicionais de transporte e materiais ${ }^{429}$. Isso levou a Mendes Júnior a paralisar, em meados de 1987, três obras que estava conduzindo: a Ferrovia Bagdá/Al Qaim/Akashat (contratada em 1978 e orçada em US\$ 1,2 bilhão), o Projeto do Sifão (contratado em 1984 e orçado em US\$ 346 milhões) e a Rodovia Expressway no. 1 (contratada em 1981 e orçada em US\$ 333 milhões) - as duas últimas parcialmente financiadas pelo Banco do Brasil, ainda no governo Sarney ${ }^{430}$. Ao mesmo tempo, a empreiteira abriu um processo de arbitragem internacional junto à Câmara Internacional de Comércio (International Chamber of Commerce), com sede em Paris, relativo às demandas legais contra o governo iraquiano.

Diante da paralisação dos serviços, a administração Saddam Hussein protestou duramente, o que poderia comprometer o fluxo bilateral de comércio e serviços. Como forma de evitar um desgaste no relacionamento com o Iraque, o governo brasileiro conduziu, em

\footnotetext{
${ }^{427}$ Havia outras empresas com funcionários brasileiros no Iraque, como a Volkswagen, que mantinha 18 trabalhadores, ou a HOP, empresa do setor bélico, com 23 funcionários. Ver FSP, "Construtora ainda tem 98 empregados retidos", 10 de setembro de 1990, p. A-9.

${ }^{428}$ Cerca de 30 brasileiros que, no eclodir do conflito do Golfo, encontravam-se em trânsito pelo Iraque, foram autorizados a deixar o país imediatamente. Ver FSP, "Rezek nega que Bagdá imponha precondições", 14 de agosto de 1990, p. A-10.

${ }^{429}$ Banco do Brasil. "Documento de posição: fatos relativos ao contencioso do Grupo Mendes Júnior com o Governo do Iraque", 03 de novembro de 1993, p. 4.

${ }^{430}$ MRE, GTNR-DOC/DOP-1, 25/04/1990 (secreto), p. 144.
} 
ação coordenada pelo MRE e com o apoio da Petrobrás e do Banco do Brasil, negociações que culminaram na assinatura, em dezembro de 1987, de um Protocolo de Comércio bilateral para reativar as exportações brasileiras. Em junho de 1988, dados os obstáculos para a consecução do Protocolo de Comércio bilateral, uma missão governamental brasileira foi enviada ao Iraque, com vistas a negociar um equacionamento para a superação das pendências comerciais. A delegação, chefiada pelo embaixador Paulo Tarso Flecha de Lima, então Secretário-Geral do MRE, foi integrada por altos funcionários do Banco do Brasil, da Petrobrás, da Interbrás, do Itamaraty e do Ministério da Fazenda. Formou-se, à época, uma Comissão Mista Brasil-Iraque, de modo a encaminhar as negociações ${ }^{431}$.

A decisão do governo brasileiro foi de que (a) absorveria a indenização devida à Mendes Júnior (incorporando, por conseguinte, o contencioso comercial); (b) adotaria medidas de recomposição dos compromissos em aberto da empresa, devolvendo-lhe níveis adequados de liquidez, e (c) contrataria consultores internacionais para definir o valor e a procedência legal das reclamações da Mendes Júnior. Em dezembro daquele mesmo ano, as negociações terminaram num impasse, dada a recusa do governo iraquiano em aceitar a interferência de consultores internacionais em seus contenciosos de comércio ${ }^{432}$. Caso não se chegasse a uma solução, o Iraque poderia tomar medidas executórias contra as garantias bancárias cedidas pelo governo brasileiro à Mendes Júnior, o que poderia representar um ônus de aproximadamente US\$ 400 milhões para o Tesouro Nacional ${ }^{433}$. Diante dos riscos, em fevereiro de 1989, o Brasil ofereceu nova proposta a Saddam Hussein. O governo Sarney comprometia-se a criar condições materiais objetivas para a retomada das obras pela Mendes Júnior. Em contrapartida, o governo do Iraque não tomaria qualquer medida imediata contra equipamentos e máquinas da Mendes Júnior em território iraquiano. Ambos os lados, finalmente, sustariam os respectivos contenciosos pelo prazo de um ano. Frente a esse quadro, a construtora brasileira foi paulatinamente restabelecendo meios para dar sequência às obras interrompidas dois anos antes ${ }^{434}$.

Em fevereiro de 1990, decorrido um ano do acordo bilateral, as obras ainda não haviam sido totalmente retomadas. Não se conseguiram negociar condições operacionais para viabilizá-las, sobretudo em função da demora na liberação dos créditos por parte das agências e bancos públicos brasileiros. O grave quadro econômico do Brasil não contribuía para o

\footnotetext{
${ }^{431}$ Ministério da Economia, Fazenda e Planejamento. "Relatório Final”, 23 de junho de 1992, p. 110-1.

${ }^{432}$ MRE, GTNR-DOC/DOP-1, 25/04/1990 (secreto), p. 145.

433 MRE, DOC/DOP-I/10/XPRO-L00-A10, "Promoção Comercial. Brasil-Iraque. Retomada das obras da Mendes Júnior no Iraque", 06 de abril de 1989.

${ }^{434}$ Ministério da Economia, Fazenda e Planejamento. "Relatório Final”, 23 de junho de 1992, p. 118-9.
} 
encaminhamento da questão, nem tampouco o cenário de transição, que já esvaziara os poderes e prerrogativas objetivos do governo Sarney. No dia 19 daquele mês, o SecretárioGeral do MRE, Paulo Tarso Flecha de Lima, envia nova carta ao Ministro do Comércio do Iraque, Mohammed M. Saleh, requerendo oficialmente a prorrogação do congelamento dos contenciosos por mais cinco meses. A resposta do governo iraquiano veio dois meses mais tarde, em 22 de abril, já dirigida ao chanceler Rezek: "[e]u, sinceramente, espero que esse bondoso gesto da parte de meu governo, a despeito do longo atraso na conclusão das obras de relevantes projetos, seja lealmente reciprocado pela dita empresa [Mendes Júnior] pela intensificação de suas atividades futuras e acelerar as obras destes projetos”. Três dias mais tarde, o ministro encaminha pedido formal à titular da Economia, Zélia Cardoso de Mello, solicitando expediência na solução dos créditos à Mendes Júnior ${ }^{435}$. As relações pareciam voltar à normalidade.

A invasão do Kuwait pelo Iraque, em agosto de 1990, colocou novamente o relacionamento bilateral em risco. Como já foi dito, a resolução 661 do Conselho de Segurança da ONU decretou completo embargo econômico-financeiro ao governo de Saddam Hussein. Em decorrência, o presidente Collor editou o Decreto no. 99.441, em 7 de agosto, tornando impossível o cumprimento dos contratos de fornecimento de bens e serviços celebrados entre a Mendes Júnior e o Iraque ${ }^{436}$. Uma semana mais tarde, já antecipando as complicações políticas que certamente adviriam da crise do Golfo, a embaixada do Brasil em Bagdá envia uma carta à construtora brasileira, nos seguintes termos:

\footnotetext{
“Em função da deterioração da situação política no Oriente Médio, em particular no Iraque e no Kuwait, bem como da iminência de ações militares, de acordo com instruções urgentíssimas do Ministério das Relações Exteriores, determino a evacuação dos funcionários dessa Empresa que se encontram no acampamento do Projeto Main Outfall Drain, para o acampamento do Projeto Expressway Number 1, trecho 10, para efeitos de retirada dos referidos cidadãos brasileiros para a Jordânia, por via terrestre, à medida que forem obtidos os necessários documentos de viagem" 437
}

Três dias mais tarde, outra carta é enviada à sede da empresa, em que o encarregado de negócios do Brasil em Bagdá, René Loncan, reforça a necessidade da evacuação total dos funcionários brasileiros, mesmo que isso incorresse em prejuízos para a Mendes Júnior: “Em aditamento à minha carta (...) e à nossa conversação telefônica desta manhã, confirmo, caso a correspondência em apreço tenha pecado pela imprecisão, que a determinação relativa à

\footnotetext{
${ }^{435}$ MRE, GTNR-DOC/DOP-1, 25/04/1990 (secreto), p. 147.

${ }^{436}$ Banco do Brasil. "Parecer COJUR/CONIN-CJA-90/262", 12 de setembro de 1990.

${ }^{437}$ Idem, p. 4.
} 
imediata obtenção de vistos de saída diz respeito à totalidade dos funcionários desta empresa" ${ }^{438}$.

O problema concreto é que o governo do Iraque já havia manifestado que só libertaria os mais de 450 cidadãos brasileiros no país quando o Brasil voltasse a exportar alimentos para o país. Embora o chanceler Rezek negasse que Saddam Hussein tivesse vinculado a concessão de vistos de saída ao envio de bens e alimentos por parte do Brasil, as negociações para a retirada dos brasileiros caminhavam muito lentamente, dando indícios de que haveria a exigência de uma contrapartida do lado iraquiano. Nem mesmo um telegrama enviado pelo presidente Collor ao ditador árabe pedindo-lhe autorização para a retirada dos brasileiros, no dia 11 de agosto, surtiu o efeito desejado. A fuga de alguns engenheiros da Mendes Júnior para a Jordânia, naquele ínterim, somente colaborava para o agravamento das tensões ${ }^{439}$. Mesmo garantindo que o governo iraquiano emitiria os vistos de saída aos brasileiros, Rezek manifestou sua insatisfação com Saddam Hussein ao declarar, em entrevista à rádio Jornal do Brasil, que o Brasil reveria sua posição de negociar armas ou manter qualquer tipo de cooperação militar com o Iraque ${ }^{440}$. Dias mais tarde, tendo em vista a crescente indisposição do governo iraquiano em libertar os estrangeiros, Rezek declarou que haveria "embaraços" nas relações bilaterais entre os dois países, caso se mantivesse o atraso na concessão dos vistos $^{441}$.

Aos poucos, a situação dos estrangeiros no Iraque e no Kuwait foi se deteriorando. No dia 18 de agosto, o governo iraquiano disse que os cidadãos retidos de outros países sofreriam racionamento de alimentos, em função do embargo da ONU às transações comerciais com o país. A pressão dos governos ocidentais - especialmente dos Estados Unidos - aumentava, não se descartando a possibilidade de uso da força militar contra o governo de Saddam Hussein em defesa da integridade dos nacionais estrangeiros (a quem Bush já tratava como "reféns" ${ }^{442}$ ) e da soberania do Kuwait. Para evitar uma escalada e transmitir certa sensação de normalidade, o governo iraquiano começou a liberar, a conta-gotas, alguns estrangeiros dentre os quais quase uma centena de brasileiros, em sua maioria mulheres e crianças. Contudo, aqueles com contrato de trabalho não poderiam sair, devendo respeitar seus compromissos empregatícios, que seriam mantidos normalmente, de acordo com as

\footnotetext{
${ }^{438}$ Idem, grifo nosso.

${ }^{439}$ FSP, “Iraque vincula saída de brasileiros a exportações”, 14 de agosto de 1990, p. A-10.

${ }^{440}$ FSP, "Brasil revê cooperação", 14 de agosto de 1990, p. A-10.

${ }^{441}$ FSP, "Itamaraty já acha difícil a liberação", 17 de agosto de 1990, p. A-14.

${ }^{442}$ FSP, "Bush diz que estrangeiros são reféns de Bagdá", 21 de agosto de 1990, p. A-12.
} 
autoridades iraquianas ${ }^{443}$. Entre os funcionários retidos da Mendes Júnior, que somavam mais de duzentos, a ansiedade tornava-se insuportável ${ }^{444}$. O quadro se agravou ainda mais quando, em decisão surpreendente, a Jordânia anunciou o fechamento de sua fronteira, por onde já haviam passado mais de 185 mil refugiados ${ }^{445}$.

Restava à diplomacia brasileira minimizar os danos políticos, mas mantendo uma abordagem realista. No dia 23 de agosto, pela primeira vez o Itamaraty admitiu, por meio de seu porta-voz, José Vicente Pimentel, que os brasileiros mantidos no Iraque corriam risco de vida $^{446}$ - embora negasse chamá-los de "reféns", como o fizera Bush, por se tratar de uma “deturpação" do termo ${ }^{447}$. No mesmo dia, em depoimento à Comissão de Relações Exteriores do Senado, o chanceler Rezek disse estar pessimista em relação a uma saída negociada para o conflito no Golfo. Segundo o ministro, "já parece impossível debelar a crise sem violência, sem o confronto armado". Quando perguntado sobre o papel do Brasil, Rezek não descartou a possibilidade de o governo participar de uma força de paz das Nações Unidas, caso ela viesse a se formar ${ }^{448}$. Consciente dos altíssimos custos que poderiam decorrer da permanência dos brasileiros no Iraque, o MRE solicitou, nos primeiros dias de setembro, que as três empresas que ainda mantinham funcionários em território iraquiano - Maxion, Volkswagen e Mendes Júnior - rescindissem unilateralmente seus contratos com agências governamentais de Saddam Hussein, como forma de viabilizar a retirada dos brasileiros do país. Ainda que isso comprometesse os investimentos e patrimônios destas companhias, todas acataram a decisão do governo Collor. Consequentemente, no dia 9 de setembro, o governo iraquiano anunciou a concessão de vistos de saída a mais 146 brasileiros. Com outros 149 cidadãos permanecendo à espera de liberação, as preocupações consulares pareciam encaminhadas, sendo sua solução somente uma questão de tempo ${ }^{449}$.

O que o governo brasileiro não esperava era a reviravolta que ocorreu no dia 10 de setembro. Alegando entraves burocráticos no encaminhamento do contrato com a Mendes Júnior, o governo iraquiano voltou atrás na concessão dos vistos, que anunciara no dia anterior. Exigiu da construtora brasileira a subcontratação de uma empresa iraquiana para dar continuidade às obras interrompidas, sem que isso incorresse em gastos ao governo local -

\footnotetext{
${ }^{443} \mathrm{O}$ embaixador do Iraque no Brasil, Qais Tawefiq Al-Mukhtar, disse, perante o Congresso Nacional, que os brasileiros não poderiam deixar o território iraquiano "enquanto não cumprirem seus contratos". Ver FSP, "Bagdá recusa vistos a brasileiros com contrato", 20 de agosto de 1990, p. A-11.

${ }^{444}$ FSP, "Brasil negocia saída de pessoas com contratos", 22 de agosto de 1990, p. A-12.

${ }^{445}$ FSP, "Jordânia fecha a fronteira para os refugiados", 23 de agosto de 1990, p. A-13.

${ }^{446}$ FSP, "Itamaraty admite que reféns correm riscos", 23 de agosto de 1990, p. A-14.

${ }^{447}$ NYT, "Gulf Crisis has Brazil in a Tailspin”, 27 de agosto de 1990.

${ }^{448}$ FSP, "Rezek não crê em solução pacífica para crise”, 24 de agosto de 1990, p. A-14.

${ }^{449}$ FSP, "Iraque dá visto de saída para 146 brasileiros", 10 de setembro de 1990, p. A-9.
} 
reivindicação considerada “inviável” pela Mendes Júnior, em função dos custos e do próprio embargo internacional ${ }^{450}$. Ao mesmo tempo, o embaixador iraquiano no Brasil, Tawfiq AlMukhtar, oficializou uma solicitação junto ao Itamaraty de que o governo brasileiro lhes enviasse imediatamente 60 mil toneladas de açúcar, um carregamento de frangos e outro de autopeças, contratados por Saddam Hussein antes do início da crise no Golfo. O pedido iraquiano foi imediatamente rejeitado pelo Brasil - que, coerente com sua posição original, alegou que a resolução 661 do CSNU tornava impossível a entrega de produtos brasileiros ${ }^{451}$.

A jogada iraquiana deixou o Brasil entre a cruz e a espada. Ceder às pressões de Saddam Hussein por alimentos - que certos diplomatas brasileiros, secundados pelos meios de comunicação, já chamavam de "chantagem" - significaria romper com o consenso multilateral de que o país fazia parte, elemento fundamental para a consolidação da credibilidade internacional do Brasil. Ao mesmo tempo, esticar a corda contra um regime que já se mostrara disposto a levar a anexação do Kuwait às últimas consequências poderia colocar em risco a vida dos mais de 300 brasileiros retidos no Iraque, cuja vida ou integridade dependiam, no limite, da atuação diplomática do governo Collor ${ }^{452}$.

A solução encontrada pelo Brasil foi enviar, no dia 11 de setembro, uma missão diplomática especial para negociar, junto ao governo iraquiano, a liberação dos vistos de saída. Três experientes embaixadores foram destacados para a tarefa: Paulo Tarso Flecha de Lima, ex-Secretário-Geral do MRE e então titular da embaixada em Londres; Sérgio Tutikian, então cônsul em Assunção, com passagens pelas embaixadas em Teerã e Bagdá; Antonio do Amaral Sampaio, considerado o maior especialista em Oriente Médio do Itamaraty, diretor do Departamento de Oriente Próximo (Deop) do Ministério ${ }^{453}$. Rememorando o episódio, Flecha de Lima atribui a decisão de nomeá-lo chefe da missão ao chanceler Rezek, por quem não nutria grande simpatia: "ele [Rezek] sabia que se tratava de missão impossível. Queria

\footnotetext{
${ }^{450}$ FSP, "Porta-voz do Itamaraty admite impasse em negociação com Bagdá", 12 de setembro de 1990, p. A-10.

${ }^{451}$ FSP, "Brasil veta envio de comida e bens ao Iraque", 12 de setembro de 1990, p. A-10.

${ }^{452}$ Nas palavras do embaixador Sérgio Tutikian, um dos enviados do Itamaraty na missão especial ao Iraque, "Saddam Hussein [era] muito temido pelo seu povo... ele era de extrema crueldade, capaz de, numa reunião ministerial, abater os seus ministros, andava sempre armado (...). Quando eclodiu a primeira Guerra do Golfo, o Brasil (...) ficou com mais ou menos 400 brasileiros retidos no Iraque que, num primeiro momento, Saddam Hussein havia dito que serviriam de escudo quando houvesse bombardeios ao palácio". Entrevista à TV Zero Hora, 25 de março de 2014. Disponível em http://videos.clicrbs.com.br/rs/zerohora/video/geral/2014/03/compalavra-sergio-tutikian-embaixador-brasileiro-que-serviu-iraque-saddam-hussein/70043/ . Acesso em $12 \mathrm{de}$ outubro de 2014.

${ }^{453}$ FSP, "Brasileiros não têm visto e governo adia resgate", 11 de setembro de 1990, p. A-15.
} 
claramente me queimar", lembra o embaixador ${ }^{454}$. A história contada pelo ex-chanceler é outra:

\begin{abstract}
"Paulo Tarso Flecha de Lima é um homem de ação, tanto quando eu o mandei para o Iraque pra liberar, como libertou com sucesso os brasileiros, a ideia era essa, era que fosse alguém de quem nunca se ouve frase do tipo: 'Fiz o meu melhor, fiz o meu possível, mas não deu certo'! Jamais sairia essa frase da boca do Paulo Tarso. Então era preciso que um homem assim fosse lá e resolvesse o problema" ${ }^{455}$
\end{abstract}

De todo modo, a solução para o problema dos brasileiros retidos era urgente. As pressões vinham de todos os lados. As empresas cujos funcionários ficaram no Iraque queriam minimizar suas perdas financeiras e a Mendes Júnior, em particular, ainda relutava em ceder às demandas iraquianas. Isso levou o chanceler brasileiro a solicitar, oficialmente, a colaboração da construtora, em carta endereçada ao seu presidente, Murillo Valle Mendes:

\begin{abstract}
"Estou ciente de que, contra todas as expectativas, o Governo do Iraque, que anunciara a liberação dos súditos brasileiros vinculados a essa empresa e retidos em seu território, entendeu de inovar a exigência de que a Mendes Júnior confie a súditos ou empresas locais a responsabilidade não apenas pela guarda de seu patrimônio, mas ainda pela continuidade, se e quando possível, das obras.

Considerada a natural ansiedade que se abateu sobre os brasileiros retidos naquele país e vinculados a sua empresa, bem assim de suas famílias e de toda a sociedade brasileira, apelo a Vossa Senhoria e a seus consócios, em nome do Governo brasileiro, no sentido de que tudo façam, no que da empresa depende, para possibilitar a imediata liberação desses compatriotas nossos. Estou certo de que, superada a crise, não escapará a qualquer cidadão de bom senso ou a qualquer foro internacional a exata percepção das circunstâncias em que sua empresa, prestigiando acima de tudo os valores humanos, ter-se-á submetido às injunções das autoridades do governo do Presidente Saddam Hussein.
\end{abstract}

Não lhe faltará, em hipótese alguma, o apoio diplomático que lhe possa ser necessário desde logo, ou ao longo dos desdobramentos de nosso esforço comum para a solução deste grave problema" ${ }^{456}$.

A pressão também vinha de uma necessidade política de curto prazo. As eleições para governos estaduais e para o Congresso Nacional ocorreriam em três semanas, e o sucesso dos aliados de Collor era uma questão de vida ou morte para o presidente - que governava com

\footnotetext{
${ }^{454}$ Entrevista ao autor. Brasília, 10 de maio de 2010. Em outra versão, publicada na Folha de São Paulo, a ideia de enviar o embaixador Flecha de Lima ao Iraque - com o mesmo propósito de "queimá-lo", foi do Secretário Nacional de Assuntos Estratégicos, Pedro Paulo Leoni Ramos. Ver FSP, "Missão pode 'queimar' diplomata", 15 de setembro de 1990, p. A-14.

${ }^{455}$ Entrevista ao autor. São Paulo, 23 de abril de 2010.

${ }^{456}$ MRE. "Carta do Ministro das Relações Exteriores, Francisco Rezek, ao Dr. Murillo Valle Mendes", C/SGP/DEOP/CASC-L00-A10, 11 de setembro de 1990.
} 
uma fração ínfima do poder legislativo (33,9\% da Câmara) ${ }^{457}$ e esperava que, após o pleito de outubro, pudesse reverter a situação. A aposta estava quase totalmente ligada ao êxito do Plano Collor, que já dava claros sinais de esgotamento. Por isso mesmo, ainda que a questão dos brasileiros no Iraque não fosse uma questão central no debate eleitoral do período, um potencial fracasso diplomático de Collor de Mello (com resultados humanos catastróficos) poderia ter impactos negativos decisivos na nova base legislativa que se formaria a partir de $1991^{458}$.

Finalmente, e mais importante, havia uma enorme pressão internacional para que o Brasil rompesse com o Iraque de uma vez por todas - o que era incompatível com a urgência do resgate dos brasileiros retidos. A questão não era só o comércio, mas sim os contatos militares que o país mantinha com o regime de Saddam Hussein desde fins da década de 1970. Mesmo antes da eclosão do conflito do Golfo, momento no qual as relações do mundo - e dos Estados Unidos - com o Iraque ainda eram consideradas "normais”, já havia certa cobrança norte-americana quanto ao Brasil no sentido de interromper a cooperação no campo da indústria bélica que mantinha com seu parceiro árabe. Em artigo de opinião no New York Times, assinado por dois especialistas em controle de armamentos nucleares, questionava-se a política estadunidense de autorizar a venda, por parte da gigante de computadores IBM, de um supercomputador ao governo brasileiro, por meio da Embraer. Segundo o texto, um grupo de engenheiros brasileiros - "mercenários high-tech", nos termos dos autores - liderados pelo major-brigadeiro da reserva Hugo de Oliveira Piva, ex-diretor do Centro de Tecnologia Aeroespacial (CTA), ligado à Embraer, haviam sido contratados pelo governo iraquiano para ajudá-lo a desenvolver armamentos de destruição em massa ${ }^{459}$.

A acusação era múltipla: empresa de Piva, HOP Consultoria, estaria mantendo funcionários no Iraque desde outubro de $1989^{460}$, cuja função era treinar os iraquianos em aerodinâmica de foguetes, testes de voo e controle de trajetórias de foguetes. Isso explicaria, por exemplo, por que o regime de Saddam havia lançado, em dezembro daquele ano, "um foguete espacial grande o bastante para colocar satélites em órbita". Além disso, o general Piva, enquanto trabalhava na CTA, especializou-se em converter o mais recente foguete nacional, o Sonda IV, em um míssil capaz de carregar uma ogiva nuclear, e também em produzir, secretamente, material nuclear bélico por enriquecimento via centrífugas de gás.

\footnotetext{
${ }^{457}$ Figueiredo, Argelina Cheibub. "Government Coalitions in Brazilian Democracy". Brazilian Political Science Review, vol. 1, no. 2, 2007, p. 190.

${ }^{458}$ Essa perspectiva eleitoral é confirmada, em entrevista, por Sérgio Tutikian, op. cit.

${ }^{459}$ Milholin, Gary e Dantzic, David. "Must the U.S. Give Brazil and Iraq The Bomb?". The New York Times, 29 de julho de 1990.

460 OESP, "Engesa contesta versão de funcionários", 25 de agosto de 1990, p. 9.
} 
Seus contatos com a Embraer de um lado e com o governo do Iraque, do outro, poderiam fazer com que o supercomputador da IBM fosse utilizado para a fabricação da bomba atômica iraquiana, bem como de mísseis de longa distância. O artigo criticava duramente tanto a postura da IBM, que negava a existência de relações entre a Embraer e o Iraque, quanto dos Departamentos de Estado e de Comércio dos EUA, que pressionavam pela venda do supercomputador ao Brasil. "Por suas razões distintas, eles estão prontos para ignorar a ultrajante ajuda brasileira ao Iraque e arriscar ajudar Brasil e Iraque a conseguirem a bomba. Eles estão enviando ao mundo um sinal nefasto: lucros e objetivos diplomáticos vagos são mais importantes que não-proliferação nuclear" ${ }^{\natural 61}$.

Desde o início da crise no Golfo, a presença de 23 funcionários da HOP no Iraque tornou-se um problema diplomático particular. Ao contrário dos demais brasileiros, eles não demonstraram interesse em sair do país, tampouco solicitaram auxílio do Itamaraty. Como se tratava de oficiais da reserva das Forças Armadas e vinculados, ainda que indiretamente, a empresas públicas, o governo brasileiro temia que a presença desses engenheiros criasse graves transtornos nas relações internacionais do Brasil, uma vez que poderiam ser responsabilizados por colaborar nos potenciais atos de agressão vindos do regime de Saddam Hussein. Por isso mesmo, o presidente Collor reuniu-se com o ministro da Aeronáutica, brigadeiro Sócrates da Costa Monteiro, e um grupo de oficiais no dia 24 de agosto, com vistas a buscar alternativas para minimizar o "embaraço político" causado por aqueles funcionários. De acordo com um general, os brasileiros não poderiam deixar o país nem que quisessem: “eles têm segredos militares que Saddam Hussein não deixará escapar sob hipótese alguma" ${ }^{\natural 62}$. No front diplomático, Rezek, embora negasse que a presença dos engenheiros pudesse comprometer "a situação do Brasil perante a comunidade internacional", fez um apelo "ao patriotismo" daqueles brasileiros para que suspendessem seus contratos com o governo iraquiano 463 .

A insistência dos engenheiros em permanecer em solo iraquiano fez aumentar as críticas domésticas nos EUA quanto à venda de tecnologia militar para o governo brasileiro e acabou levando o Bush a manifestar, abertamente, sua insatisfação quanto ao relacionamento entre Brasil e Iraque. Um editorial do New York Times, do dia 8 de setembro, exigia que os Estados Unidos cessassem as "vendas indiscriminadas de armas de alta tecnologia", passando a lidar com os fornecedores de conhecimento militar ao regime de Saddam Hussein com base

\footnotetext{
${ }^{461}$ Milholin e Dantzic, op. cit. Grifo nosso.

462 OESP, "Embaixada do Brasil é fechada em Al-Kuwait", 25 de agosto de 1990, p. 9.

${ }^{463}$ FSP, "Ministro critica atuação de assessores militares", 24 de agosto de 1990, p. A-14.
} 
na ameaça. "Let the sellers beware", clamava o artigo ${ }^{464}$. Um mês mais tarde, o congressista Doug Bereuter (R-Nebraska), declarava em plenário: "De sua parte, dos Estados Unidos devem usar sua alavancagem diplomática para urgir a ratificação brasileira do pacto (sic) de não-proliferação nuclear" ${ }^{\text {,65 }}$.

Ao mesmo tempo, em Israel - um dos alvos declarados do governo iraquiano, caso eclodisse uma guerra -, a grande imprensa fustigava o Brasil. Desde antes da invasão do Kuwait, mas especialmente a partir de então, os meios de comunicação locais expressavam, sistematicamente, todo seu temor de que o governo brasileiro, que havia recentemente buscado restabelecer relações construtivas com Israel por meio de várias demonstrações de simpatia por parte do presidente Collor de Mello, estivesse colaborando com o Iraque no campo nuclear ${ }^{466}$. Destacavam, por exemplo, a indisposição do novo governo em assinar o Tratado de Não-Proliferação Nuclear (TNP), "uma vez que tal assinatura estrangularia o avanço do Brasil no campo da energia nuclear" 467.

\subsubsection{O descolamento entre presidente e diplomacia: duas frentes simultâneas}

O quadro internacional descrito acima joga luz sobre duas decisões imediatas tomadas pelo governo Collor. A primeira foi o envio da missão especial a Bagdá, como forma de evitar um desgaste diplomático ainda maior para o Brasil. A ideia era negociar a retirada completa dos brasileiros em três dias ${ }^{468}$, realizando uma ambiciosa ofensiva diplomática, que incluía a ajuda de parceiros árabes como a OLP, Iêmen, Tunísia e Argélia, além das Nações Unidas e da Cruz Vermelha Internacional ${ }^{469}$. Haveria, além disso, a busca de uma aproximação a Tareq Aziz, chanceler de Saddam Hussein, e a outros importantes diplomatas iraquianos ${ }^{470}$.

A segunda decisão, concomitante à primeira, era uma resposta simbólica às pressões americano-israelenses, antecipando possíveis estranhamentos diplomáticos em função da aproximação tática do Brasil a países árabes. No dia 18 de setembro, poucos dias após a chegada ao Iraque da missão chefiada por Flecha de Lima, Collor fez aquilo que talvez tenha

\footnotetext{
${ }^{464}$ NYT, “Who's making missiles for Iraq?”, 8 de setembro de 1990.

465 Congressional Record (101st Congress, 1989-1990). "Revelations concerning Brazil's nuclear weapon program", 22 de outubro de 1990, p. E3391.

${ }^{466}$ Ver, entre outros, telex de BRASEMB TEL-AVIV para EXTERIORES, 06 de agosto de 1990 (MSG 0F00160Z).

${ }^{467}$ Telex de BRASEMB TEL-AVIV para EXTERIORES, 24 de abril de 1990 (MSG 0F00080Z).

${ }^{468}$ Essa informação, embora não divulgada à época, foi dada pelo embaixador Sérgio Tutikian em entrevista, op. cit. Ver também FSP, "Plano da missão era liberar os brasileiros em apenas três dias", 25 de setembro de 1990, p. A-11.

${ }^{469}$ FSP, "Itamaraty recorre à OLP para liberar reféns", 14 de setembro de 1990, p. A-10.

${ }^{470}$ FSP, “Missão diplomática vai amanhã a Bagdá encontrar com Tareq Aziz”, 14 de setembro de 1990, p. A-10.
} 
sido o mais importante ato simbólico de seu governo. Em visita à Serra do Cachimbo, no Pará, o presidente colocou uma pedra e duas pás de cal no poço de Cachimbo, construído na década de 1980 para abrigar experiências com armas nucleares. O gesto, que ocorreu a três dias da viagem de Collor a Nova York para participar da abertura da Assembleia Geral da ONU, servia para dirimir, de uma vez por todas, as suspeitas internacionais em torno do programa nuclear brasileiro. "Tapar esse buraco é por fim a essas especulações de que o Brasil quer fabricar bombas nucleares, da maneira mais clara possível", afirmou o secretário de Ciência e Tecnologia, José Goldemberg ${ }^{471}$. "Esse poço, que tinha como finalidade servir para experiências atômicas, é produto de um pensamento diferente, de um tempo diferente", completou o secretário nacional de Meio Ambiente, José Lutzenberger ${ }^{472}$. Admitir que o Brasil possuía instalações para testes nucleares, na visão do governo Collor, era a melhor maneira de reforçar seu compromisso com a não-proliferação ${ }^{473}$.

A partir de então, o governo brasileiro passou a trabalhar em duas frentes simultâneas. No Iraque, a missão de Flecha de Lima buscava, insistentemente, negociar a saída dos brasileiros junto às autoridades iraquianas. Em quatro dias, os diplomatas do MRE reuniramse com nada menos que seis ministros, o presidente da estatal de petróleo do país e um membro do Conselho da Revolução. O encontro mais importante (e difícil), contudo, não se traduziu em resultados concretos. Após adiar a reunião por três dias, o chanceler Tareq Aziz negou-se a garantir o visto de saída aos brasileiros e criou uma "comissão" para estudar o caso $^{474}$. Mesmo diante da negativa iraquiana, Rezek tentava contemporizar: "continuamos com uma grande esperança de êxito, pelo menos parcial se não for total" ${ }^{475}$. Figura tradicionalmente descolada do jogo de interesse político-partidário, o chanceler se tornava responsável por evitar uma grande derrota diplomática, que poderia ter repercussões negativas às vésperas de eleições nacionais.

A segunda frente, cuja batalha estava sendo travada pelo próprio presidente Collor, dizia respeito aos Estados Unidos. No discurso de abertura da Assembleia-Geral, em 24 de setembro, o presidente brasileiro faz vagas menções à crise do Iraque, embora reitere, de maneira textual, a determinação de seu governo "de, no âmbito de sua jurisdição interna,

\footnotetext{
${ }^{471}$ O Globo, "Collor fecha buraco para testes atômicos", 19 de setembro de 1990, p. 20.

472 O Globo, "Governo admite finalidade do poço", 19 de setembro de 1990, p. 20.

${ }^{473} \mathrm{O}$ gesto do presidente foi bem-recebido pelo governo Bush. Ver FSP, "EUA apoiam decisão de Collor de fechar escavação em Cachimbo", 28 de setembro de 1990, p. A-5.

${ }^{474}$ FSP, "Itamaraty fracassa no encontro com Tareq Aziz", 20 de setembro de 1990, p. A-19.

475 FSP, “Missão tem 'perspectiva de êxito', diz Rezek”, 21 de setembro de 1990, p. A-13.
} 
cumprir de forma integral a Resolução 661 do Conselho de Segurança»"476. Com relação à questão nuclear, vale-se do compromisso brasileiro relativo ao Tratado de Tlatelolco ratificado pelo Brasil em 1967 mas nunca tendo entrado em vigor - para subscrever à nãoproliferação:

\begin{abstract}
"O Brasil ratificou o Tratado de Tlatelolco, e tem reiterado, nos foros internacionais, seu respeito aos propósitos deste e de outros acordos internacionais congêneres. Ainda recentemente, Brasil e Argentina anunciaram de público que a implementação do Tratado de Tlatelolco está sendo objeto de intensa troca de opiniões entre as partes interessadas. Esse tratado, iniciativa latino-americana pioneira no campo da não-proliferação de armas nucleares, precedeu qualquer outro esforço de caráter regional ou universal voltado ao mesmo objetivo. Penso, contudo, que é chegado o momento de ir mais longe ainda. O Brasil de hoje descarta a ideia de qualquer experiência que implique explosões nucleares, ainda que para fins pacíficos, e espera que outros países considerem a hipótese de tomar o mesmo caminho"477
\end{abstract}

De volta ao front iraquiano, as negociações continuavam a passos lentos. A missão brasileira conseguira autorização para o visto de saída de 256 brasileiros, concedidos a contagotas pela lenta burocracia do regime de Saddam Hussein. Não obstante, o avião da Iraqi Airways que foi preparado para levar de volta os funcionários brasileiros, em prontidão desde o dia 25 de setembro, teve sua decolagem adiada diversas vezes por atrasos no carimbo dos passaportes. Por uma questão logística e como estratégia para pressionar as autoridades iraquianas, o Itamaraty decidiu que só partiria com todos os brasileiros ${ }^{478}$. Collor ainda tentou uma jogada de prestígio pessoal ao solicitar ao rei Hussein da Jordânia, em conversa telefônica, auxílio na resolução do problema dos brasileiros retidos ${ }^{479}$.

O que parecia ser uma grande decisão de diplomacia presidencial esvaiu-se no dia seguinte. Ainda sem qualquer definição sobre a concessão da leva final de vistos, as agências de notícia norte-americanas publicaram, no dia $1^{\circ}$ de outubro, uma suposta declaração de Collor, em encontro particular com Bush, no qual haveria chamado o ditador iraquiano de "insano" 480 . As palavras do presidente brasileiro, reproduzidas nos jornais do Iraque e ao redor do mundo árabe, geraram nova indisposição quanto à liberação dos brasileiros. Como os vistos tinham prazo de validade - em geral, de uma ou duas semanas -, a ansiedade entre aqueles que já tinham condições de deixar o país aumentava ${ }^{481}$.

\footnotetext{
${ }^{476}$ Collor de Mello, Fernando. "Discurso à XLV Sessão Ordinária da Assembleia Geral da Organização das Nações Unidas (1990)" in Seixas-Corrêa, Luiz Felipe. A Palavra do Brasil nas Nações Unidas, p. 520.

${ }^{477}$ Idem, p. 523-4.

${ }^{478}$ FSP, "Interino vê risco na decisão do Itamaraty", 29 de setembro de 1990, p. A-14.

${ }^{479}$ FSP, "Conversa de Collor e Hussein anima diplomatas", 1 de outubro de 1990, p. A-9.

480 JB, "Notícia irritou Saddam", 3 de outubro de 1990, p. 15.

${ }^{481}$ FSP, "Engenheiros da HOP se rebelam contra Itamaraty", 2 de outubro de 1990, p. A-10.
} 
Mesmo que o subsecretário de Estado para a América Latina, Bernard Aronson, tivesse se desculpado pela "descaracterização" de sua declaração original - que sugeria que Collor havia chamado a situação da crise de "insana", não o líder iraquiano ${ }^{482}$-, a repercussão negativa das supostas palavras do presidente brasileiro obrigou Flecha de Lima a mudar de estratégia ${ }^{483}$. No dia 3 de outubro, dia das eleições estaduais e legislativas no Brasil, o MRE retirou 173 brasileiros que já possuíam os vistos de saída. Quatro dias mais tarde, conseguiu a liberação dos demais 82 funcionários - que a imprensa já chamava de "reféns". Mesmo não tendo sido uma vitória pessoal de Collor, com potenciais dividendos eleitorais, o embaixador Paulo Tarso Flecha de Lima saiu como o grande vitorioso do episódio. Em editorial, a Folha de São Paulo celebrava o sucesso da missão:

\begin{abstract}
"Conseguiu-se, afinal, providenciar a saída dos brasileiros sem que se ferissem as resoluções aprovadas pela ONU; ademais, a circunstância de o Brasil ser o único país a obter a liberação de todos seus cidadãos que desejavam abandonar de imediato o território iraquiano só vem evidenciar a importância do episódio"484.
\end{abstract}

\title{
4.6. O desfecho: desconfianças recam sobre o Brasil
}

Nos meses que se seguiram, a escalada de tensões no Golfo Pérsico deixou de canalizar exclusivamente as preocupações diplomáticas e passou a ocupar as autoridades do Ministério da Economia, cientes de que, com a proximidade de um confronto armado entre as potências ocidentais e o regime de Saddam Hussein, a explosão do preço do barril de petróleo poderia colocar o (já comprometido) controle inflacionário em risco. Entre novembro de 1990, quando o Conselho de Segurança aprovou a resolução 678, até o vencimento da datalimite imposta pela comunidade internacional para a retirada militar iraquiana do território do Kuwait (15 de janeiro de 1991), o Brasil iniciou os preparativos para aquilo que, dentro do governo, passou-se a chamar de "economia de guerra". Documento reservado entregue ao presidente Collor, na primeira semana de janeiro, delineava a estratégia do país para enfrentar

\footnotetext{
${ }^{482}$ A retratação de Aronson corresponde à versão de Rezek, em entrevista ao autor (02 de outubro de 2014). Nos registros originais do encontro entre Collor e Bush, não há qualquer menção à palavra "insano". A conversa gira em torno do compromisso brasileiro ao Tratado de Tlatelolco: "o Brasil, sob meu governo, não vai embarcar em nenhuma aventura nuclear". O presidente brasileiro também mencionou o poço do Cachimbo e sua decisão em fechá-lo de uma vez por todas. Com relação a Saddam Hussein, Collor diz: "eu lamento pelas más relações informais que tínhamos com Saddam Hussein. Como você sabe, Brazil tinha relações formais com o Iraque. Mas essas eram abertas. Infelizmente, havia relações clandestinas que eram obscuras. Isso é impensável para nós (...). Nós apoiamos todas as tentativas pacíficas para resolver o problema de Saddam. Não se pode deixar a soberania ser colocada em risco. Não se pode haver recompensas para violações do Direito Internacional. Não podemos nos dobrar a alguém como Hussein que invade outro país". Ver The White House. "Memorandum of Conversation with President Collor of Brazil". Memcon 8064, 1 de outubro de 1990.

${ }^{483}$ FSP, "Itamaraty desiste de fazer retirada em bloco", 3 de outubro de 1990, p. A-11.

${ }^{484}$ FSP, "Missão vitoriosa", 11 de outubro de 1990, p. A-2.
} 
a subida do preço do petróleo para US\$ 90 o barril, aproximadamente três vezes o valor em que o combustível havia se estabilizado desde a invasão do Kuwait ${ }^{485}$.

Preocupava também ao Brasil como lidar com a eclosão de uma eventual ação armada liderada pelos Estados Unidos. Juntar-se aos esforços militares das potências ocidentais como havia feito a Argentina - de maneira polêmica, diga-se, contestada até mesmo pela primeiradama argentina, descendente de sírios e muçulmana praticante ${ }^{486}$ - poderia ser o teste definitivo à credibilidade brasileira perante os olhos norte-americanos. Por outro lado, o Brasil já tinha se comprometido junto ao governo iraquiano, desde outubro, que não enviaria tropas ao Golfo - tendo esse argumento sido usado, “com muita ênfase”, para negociar a saída dos brasileiros do território iraquiano ${ }^{487}$.

No encontro que Collor e alguns de seus ministros tiveram com Bush, em sua visita a Brasília, fez-se questão de reforçar a posição brasileira, favorável às soluções pautadas pelo Direito Internacional, fiel aos princípios das Nações Unidas, mas orientada pelo entendimento tradicional de repúdio ao uso da força e de favorecimento dos princípios de soberania e nãointervenção. Na reunião com o presidente dos EUA, a posição de Rezek foi veemente: "Devemos preservar o respeito pelo Direito Internacional. Devemos ter um sistema internacional confiável. Temos sido bastante favoráveis a todas as decisões tomadas pelo Conselho de Segurança. Esperamos que a ONU, desta vez, seja eficaz”. A resposta de Bush foi igualmente forte, embora não houvesse uma demanda clara à contribuição militar brasileira: "Saddam está tentando fazer com que a guerra pareça ser entre o Iraque e o mundo árabe contra os Estados Unidos. Não se trata disso. Então a liderança brasileira em deixar claro que todo o mundo está contra o que o Saddam fez é de extrema importância"488.

Quando a guerra eclodiu, no dia 17 de janeiro, Collor convocou uma reunião ministerial de emergência. Nela, debateram-se as perspectivas para a economia brasileira no contexto da guerra e a questão do abastecimento de combustíveis. Em seu pronunciamento inicial, transmitido em rede nacional, o presidente apelou para o "espírito de solidariedade da sociedade" frente à crise internacional e reiterou o compromisso e a confiança do Brasil nas Nações Unidas ${ }^{489}$. Nenhuma palavra de apoio foi dirigida aos Estados Unidos ou à coalizão multinacional que entrava em solo iraquiano. De acordo com Collor, o presidente norte-

\footnotetext{
${ }^{485}$ FSP, "Governo prepara sua estratégia para guerra", 11 de janeiro de 1991, p. A-12.

486 El Tiempo, "Argentina envía tropas al Golfo", 19 de setembro de 1990. Disponível em http://www.eltiempo.com/archivo/documento/MAM-59302. Acesso em 13/08/2014.

${ }^{487}$ FSP, "Garantia de não enviar tropas liberou brasileiros", 11 de outubro de 1991, p. A-13.

488 The White House. "Meeting with President Fernando Collor de Mello of Brazil". Memorandum of Conversation no. 9819, 3 de dezembro de 1990. Grifo nosso.

${ }^{489}$ FSP, "Collor reúne minstros e pede 'solidariedade"”, 18 de janeiro de 1991, p. A-7.
} 
americano chegou a entrar em contato com ele, pedindo para que o Brasil enviasse navios, armas ou tropas ao Iraque, e obteve como resposta: "Presidente [Bush], não posso fazer nada, nenhum homem eu mandarei”,490.

Ao mesmo tempo, Menem ligou para seu contraparte Bush para manifestar "todo o apoio" do povo argentino. "Faremos todo o possível para ajudá-los - a acabar com o conflito. Apoiaremos qualquer resolução para cessar a guerra. Se as Nações Unidas nos pedir para fazer mais, nós queremos fazer" ${ }^{491}$. A diferença do tratamento era indicativa do tipo de relacionamento que os Estados Unidos esperavam de seus vizinhos ao sul - e do que acabou tendo do Brasil, em prejuízo da intimidade com que Bush tratava Collor até então. Nas correspondências oficiais, o presidente norte-americano trocou o "dear Fernando" pelo "Mr. President" ${ }^{\natural 92}$. Os próximos movimentos do relacionamento bilateral com os EUA acabaram por carregar o fardo de não termos nos alinhado aos interesses da potência hegemônica.

\footnotetext{
${ }^{490}$ Entrevista de Fernando Collor de Mello ao autor. Brasília, 13 de junho de 2011.

491 The White House. "Telephone conversation with President Carlos Menem of Argentina". Memorandum of Telephone Conversation no. 511, 19 de janeiro de 1991, p. 2.

${ }^{492}$ Spektor, Matias. "Collor estadista?". Folha de São Paulo, 27 de fevereiro de 2012.
} 


\section{CAPÍTULO 5}

\section{Modernização forçada, autonomia retórica}

A terceira fase do governo Collor é marcada por uma importante inflexão na estratégia da política externa brasileira. Como descrito no capítulo anterior, a orientação inicial da diplomacia "collorida" pautava-se por um difícil equilíbrio entre retórica primeiro-mundista, como estratégia de reconstrução da credibilidade do Brasil frente a seus parceiros, e uma atuação autonomista, visando garantir a preservação do interesse nacional. Neste segundo momento, no entanto, a intensidade das pressões estruturais sobre o Brasil - vinda tanto dos Estados quanto dos bancos credores - forçaram o governo Collor a fazer concessões, muitas das quais colocaram em risco as posições brasileiras estabelecidas anteriormente. Em outras palavras: abandonou-se, em diversos aspectos, a busca pela autonomia, e a adoção de uma retórica terceiro-mundista passou a servir como mecanismo compensatório às concessões estratégicas realizadas.

Trata-se, em primeiro lugar, de um processo ligado à deterioração do cenário doméstico, sobretudo no tocante a três principais fatores: (1) a retomada da inflação, após o fracasso de duas tentativas de estabilização (Plano Collor I, de março de 1990, e Plano Collor II, de janeiro de 1991); (2) a ausência de um acordo de renegociação da dívida junto aos bancos privados, após meses de discussão entre representantes dos credores e autoridades brasileiras; (3) o esgarçamento da base de apoio ao governo, processo que se intensificou após o lançamento do Plano Collor II, deixando o presidente sem amparo entre as elites empresariais, sindicais e políticas.

Além disso, no plano sistêmico, concluía-se o realinhamento de forças iniciado ao longo da década de 1980, cujo ápice havia sido a queda do muro de Berlim. Se, ainda como presidente eleito, Collor havia viajado pelo mundo, demonstrando semelhante interesse em aproximar-se de Estados Unidos e União Soviética, Japão e Europa, após um ano de governo ficavam claros os pontos de estrangulamento com relação ao Brasil - e a maneira como o jogo passaria a ser jogado a partir de então. Com a afirmação da hegemonia norte-americana, os espaços de atuação do Brasil reduziam-se bruscamente, forçando o país ou a ceder aos EUA em alguns pontos vistos como intransponíveis, como as tecnologias de uso dual e a questão da dívida (que também envolvia os credores privados), ou a buscar alternativas no campo diplomático - seja na retórica ou na prática - que pudessem compensar as perdas relativas no relacionamento com os norte-americanos. 


\subsection{O novo desenho da política externa brasileira}

Nessa terceira fase, a política externa brasileira prioriza as relações com a periferia. Isso traz três acepções diferentes: a periferia global, ou o Terceiro Mundo propriamente dito, o que lançou a diplomacia de Collor em direção à África - em seus extremos sul e norte - e Oriente Médio - em seus extremos não-árabes, Irã e Israel. A segunda é o que chamaremos de periferia do centro, ou seja, países do Primeiro Mundo que não se confundem com as potências industrializadas e que acabam sendo relevantes para o Brasil em tópicos pontuais como meio ambiente, tecnologia ou investimentos - ou como apoiadores, dentro de seus respectivos blocos econômicos, de uma aproximação maior com o o governo brasileiro. Por fim, temos a periferia do socialismo, ou o Leste Europeu, de quem o Brasil buscou se aproximar no contexto da transição de tais países para economia de mercado, ainda que de maneira menos enfática.

Com relação ao Terceiro Mundo, é importante distinguir a retórica da prática. No plano simbólico, o período foi praticamente todo permeado por um discurso terceiromundista, crítico das injustiças herdadas do período da Guerra Fria e que continuavam penalizando - agora em novos campos, como o ecológico - as nações menos desenvolvidas. O tom confrontacionista serve de mecanismo compensatório às concessões que o Brasil foi levado a fazer nos campos de dívida externa e tecnologias sensíveis. Por outro lado, no plano dos gestos, foi dada renovada prioridade à África austral - para onde o presidente viajou, em setembro de 1991 - e ao Maghreb - destino do chanceler Rezek, em janeiro de 1992. Em ambos os destinos, tratava-se de uma aproximação muito mais normativa que pragmática, a julgar pelas parcas oportunidades comerciais que tais regiões ofereciam ao Brasil e, em contrapartida, pelo reforço da cooperação Sul-Sul como elemento orientador das relações internacionais brasileiras. O "périplo africano" de Collor será tratado adiante neste capítulo.

As relações com Israel e Irã, que vinham distantes desde a inflexão pró-árabe do governo Geisel, devem ser compreendidas como duas facetas do mesmo processo: reduzir tensões diplomáticas oriundas de relacionamentos passados e manter o dinamismo econômico na região. Com o imbróglio causado pelo conflito do Golfo, claramente prejudicial às relações comerciais e diplomáticas brasileiras, o Brasil havia perdido o importante mercado consumidor do Iraque e, ao mesmo tempo, seu principal fornecedor de petróleo. Num primeiro momento, ainda se tentou ficar no circuito do mundo árabe: diante dos protestos da indústria bélica nacional, a Arábia Saudita absorveu, ainda que temporariamente, a produção de armamentos outrora destinada ao governo de Saddam Hussein. Mas não se tratava, dadas 
as circunstâncias, de uma atividade que o governo Collor desejava enfatizar, sob o risco de criar novas arestas diplomáticas.

A aproximação do Irã, por outro lado, era pragmática e interessava ao Brasil pelo seu valor econômico. No discurso do chanceler Rezek ao Ministro dos Negócios Estrangeiros iraniano, Ali Akbar Velayati, destacam-se as intensas atividades bilaterais no campo de infraestrutura, com a participação da construtora Andrade Gutierrez na construção da hidrelétrica Karum III, e energético: "Durante o recente conflito do Golfo, o Governo da República Islâmica do Irã deu mais uma prova de sua firme disposição de cooperar com o Brasil, ao atender prontamente nosso pedido de suprimento de quantidades suplementares de petróleo" 493 .

O mesmo vale para as relações com Israel, mas de um outro ponto de vista: embora não representasse um país com atrativos econômicos, os contatos com o governo israelense eram vistos como uma maneira lateral de agradar os Estados Unidos, com vistas a minimizar pressões norte-americanas em questões sensíveis, como dívida externa ou tecnologias de uso duplo. As promessas de Collor durante a campanha haviam lhe mostrado que boas relações com Israel eram interessantes no contexto do relacionamento mais amplo com o governo Bush. A visita de Shimon Peres, líder do partido trabalhista israelense, em 17 de abril de 1991, é um passo nessa direção. O patrocínio brasileiro à Resolução 46/86, em dezembro daquele ano, que revoga a condenação multilateral do sionismo aprovada em 1975, consolida esse processo.

Na periferia do centro, a retórica terceiro-mundista não se revelava, dando espaço à discussão de temáticas específicas de interesse à agenda brasileira. O primeiro destino de Collor nesse segundo momento foi exatamente a Espanha, entre 14 e 19 de maio de 1991. Seu objetivo, como pontua Bruno Ayllón, era "proceder à assinatura solene da ata de bases das linhas gerais do Tratado de Cooperação e Amizade, reflexo da relevância que o Brasil conferia às relações com a Espanha"494. Havia também o desejo de intensificar o fluxo de investimentos espanhóis ao país e de consolidar a península ibérica como ponto prioritário de contato entre o Mercosul e a Comunidade Econômica Europeia. Este último aspecto se mostrou, de maneira clara, pela adesão brasileira, em setembro de 1990, à iniciativa

\footnotetext{
${ }^{493}$ RPEB, "Ministro dos Negócios Estrangeiros do Irã é homenageado no Itamaraty", 31 de maio de 1991, p. 151.

${ }^{494}$ Ayllón Pino, Bruno. As Relações Brasil-Espanha na perspectiva da Política Externa Brasileira (19452005). São Paulo: Emblema, 2006, p. 205.
} 
binacional mexicano-espanhola de criação de uma Conferência de Cúpula Ibero-Americana, que se realizou pela primeira vez em Guadalajara, em julho de $1991^{495}$.

O segundo roteiro de Collor foi às nações escandinavas Suécia e Noruega. Ao contrário das relações com a Espanha, detentoras de substrato econômico, político e cultural anteriores, esses dois países pouco acrescentavam, em termos concretos, aos interesses brasileiros. As críticas ao excesso de viagens do presidente não tardaram a aparecer: "Se é verdade que o cargo de presidente da República obriga a uma série de formalidades de que muitas vezes não se pode escapar, também parece ser verdade que a sucessão de viagens do presidente brasileiro vem ultrapassando os limites do aceitável"496. De fato, a passagem pela Suécia, durante a qual Collor recebeu a "tocha ecológica" simbolizando a transferência de sede da conferência ambiental das Nações Unidas (de Estocolmo ao Rio), ficou lembrada por questões menores: a derrapada do presidente numa pista de testes da Scania, pilotando um caminhão e o compromisso do presidente Gorbachev em participar da Rio-92 - a União Soviética não sobreviveu até lá ${ }^{497}$. Na Noruega, onde passou menos de 24 horas, Collor reuniu-se com a primeira-ministra Gro Harlem Brundtland, conhecida como a "ministra mundial do ambiente", em função de sua contribuição para o debate ambiental ${ }^{498}$.

Em 30 de novembro de 1991, o presidente Collor embarcou para Cartagena, na Colômbia, onde participou do $5^{\circ}$ Encontro do Grupo do Rio, no qual os presidentes dos doze países-membros debateram uma extensa pauta. Entre os principais temas, estavam a situação de Cuba, segurança energética, combate ao narcotráfico e preservação ambiental na América Latina. Os chefes de Estado também reiteraram seu apelo aos governos do Primeiro Mundo e

\footnotetext{
${ }^{495}$ Embora as conferências ibero-americanas tenham se originado de entendimentos de natureza reservada entre os governos mexicano e espanhol, a iniciativa somente se consolidou com a adesão do Brasil aos dois copatrocinadores originais, em setembro de 1990. No caso brasileiro, prevalecia o desejo de assegurar a autonomia nacional na busca dos interstícios de poder, num quadro de afirmação hegemônica dos Estados Unidos. O próprio convite ao Brasil era, no eixo entre América Latina e Europa, um sinal de prestígio. O presidente Salinas quis demonstrar à opinião pública doméstica e a seus parceiros latino-americanos que o México, ao estender sua mão aos Estados Unidos, não abandonava suas vinculações políticas com os vizinhos ao sul do hemisfério nem abandonava o compromisso do país com sua autonomia - conceito caro a mexicanos e brasileiros, em termos muito parecidos. Ao mesmo tempo, a Espanha buscava reforçar sua nova condição de potência econômica, propulsionada pela integração europeia e pela afirmação democrática, e que já se manifestava na realização de eventos de porte global como a Exposição Universal de Sevilha e os Jogos Olímpicos de Barcelona. Para ambos os países, a simbologia do descobrimento da América e da integração dos povos parecia adequada (conquanto potencialmente controvertida) na busca de seus objetivos internacionais. "O México obteria de imediato o respaldo simbólico de que necessitava para sua abertura ao Norte, e a Espanha assegurar-se-ia da presença, em Madri, nas comemorações do V Centenário, dos mandatários latino-americanos”. Ver Seixas-Corrêa, Luiz Felipe de, 1997, p. 153.

${ }^{496}$ FSP, "Excesso de viagens", 7 de junho de 1991, p. 1-2.

${ }^{497}$ OESP, "Gorbachev aceita convite para vir ao Brasil", 7 de junho de 1991, p. 4.

498 Os noticiários brasileiros, contudo, deram mais atenção à reação de Collor ao saber que seu ministro do Trabalho, Antônio Rogério Magri, que se encontrava em Genebra, havia sido flagrado em um passeio de compras no momento da reunião da Organização Internacional do Trabalho (OIT), motivo de sua viagem à Suíça. FSP, “Collor afirma que vai checar passeio de Magri”, 8 de junho de 1991, p. 1-5.
} 
às instituições financeiras internacionais para que a dívida externa de seus respectivos países recebesse tratamento político, não afetando compromissos estabelecidos domesticamente.

Em meados de dezembro, Collor visita a Itália e a Áustria. Em Roma, no encontro que manteve com o primeiro-ministro italiano Giulio Andreotti e o presidente Francesco Cossiga, a intenção do presidente era reativar o comércio bilateral - que havia reduzido $30 \%$ entre 1989 e 1990 - e discutir a liberação de um empréstimo de US\$ 920 milhões previsto no Acordo de Cooperação Econômica, Científica e Tecnológica de $1989^{499}$. Em Viena, Collor assinou o Acordo Quadripartite entre Argentina, Brasil, ABACC e AIEA, cujo processo será detalhado a seguir.

Outros parceiros com quem o Brasil buscou estreitar relações, embora não em nível presidencial, obedecem ao mesmo padrão de explorar possibilidades na periferia do centro. Em 8 de agosto de 1991, o Brasil assinou com a Coreia do Sul acordo sobre cooperação nos campos científico e tecnológico. Embora os objetivos do documento fossem relativamente modestos, chama-se a atenção para a decisão de se criar uma Comissão Mista Brasil-Coreia sobre Ciência e Tecnologia ${ }^{500}$. No início de janeiro de 1992, o chanceler da República da Irlanda, Gerard Collins, visitou o Brasil e foi recebido por seu contraparte, Francisco Rezek. As circunstâncias para a aproximação com o governo da Irlanda eram bastante favoráveis: o governo Collor já tinha buscado estreitar laços com as três principais nações europeias Alemanha, França e Itália - bem como com os países ibéricos, de cuja matriz cultural o Brasil se aproximava. Além disso, menos de um mês antes, as doze nações da Comunidade Europeia, representadas por seus chefes de Estado e governo, haviam se reunido na cidade holandesa de Maastricht e acordado sobre a assinatura do Tratado da União Europeia. Permanecia o interesse brasileiro de aprofundar a integração entre o Mercosul e as grandes economias do Velho Mundo ${ }^{501}$.

\section{Tabela 3 - Viagens presidenciais na terceira fase do governo Collor (mai/91 a abr/92)}

\begin{tabular}{|l|l|l|}
\hline Data & Países & Motivo da viagem \\
\hline 14 a 20 de maio & Espanha & $\begin{array}{l}\text { Assinatura da primeira versão do Tratado de } \\
\text { Cooperação e Amizade entre os dois países. }\end{array}$ \\
\hline 2 a 9 de junho & Suécia e Noruega & $\begin{array}{l}\text { Comemoração do Dia Mundial do Meio } \\
\text { Ambiente, em que recebeu a tocha } \\
\text { simbólica da Eco-92, e encontro com a } \\
\text { primeira-ministra na Noruega }\end{array}$ \\
\hline
\end{tabular}

\footnotetext{
${ }^{499}$ OESP, "Collor tenta liberar empréstimo na Itália”, 10 de dezembro de 1991, p. 4; FSP, "Collor tenta reativar comércio com a Itália”, 10 de dezembro de 1991, p. 1-8.

${ }^{500}$ RPEB, “Acordo ... p .227-229

${ }^{501}$ RPEB, "Chanceler da Irlanda visita o Brasil", 1992, p. 7.
} 


\begin{tabular}{|l|l|l|}
\hline 17 a 21 de junho & EUA & $\begin{array}{l}\text { Encontro com o presidente George Bush e } \\
\text { autoridades americanas }\end{array}$ \\
\hline 17 a 18 de julho & México & $\begin{array}{l}\text { Em Guadalajara, participa da Cúpula Ibero- } \\
\text { Americana e assina o tratado da ABACC }\end{array}$ \\
\hline 7 a 14 de setembro & $\begin{array}{l}\text { Angola, } \\
\text { Zimbábue, } \\
\text { Moçambique } \\
\text { Namíbia }\end{array}$ & $\begin{array}{l}\text { Manter entendimentos com vistas a } \\
\text { consolidar e aprofundar os laços de amizade } \\
\text { com nações africanas }\end{array}$ \\
\hline $\begin{array}{l}\text { a de de } \\
\text { setembro }\end{array}$ & EUA & $\begin{array}{l}\text { Participação na Assembleia Geral das } \\
\text { Nações Unidas }\end{array}$ \\
\hline 9 de dezembro a 14 de dezembro & Itália e Áustria & $\begin{array}{l}\text { V Reunião do Grupo do Rio, juntamente } \\
\text { com outros 12 presidentes latino- } \\
\text { americanos }\end{array}$ \\
\hline $\begin{array}{l}\text { Encontro com autoridades do governo e } \\
\text { empresariais para ampliar as relações } \\
\text { bilaterais, na Itália, e oficializar junto à } \\
\text { Agência Internacional de Energia Atômica } \\
\text { (AIEA) o acordo de inspeção nuclear que } \\
\text { Brasil e Argentina assinaram em julho. }\end{array}$ \\
\hline
\end{tabular}

Fonte: Adaptado de OESP, 10 de dezembro de 1991, p. 4

\subsection{Dívida externa}

Apesar das sinalizações - muitas delas simbólicas - que orientaram a política externa em sua terceira fase, alguns processos herdados da etapa anterior se agravaram, tornando-se, inclusive, vetores causais para a mudança de comportamento que se verifica. A questão da dívida, em particular, havia sido um dos entraves mais críticos do governo Collor desde seu início. Incapaz de chegar a um acordo com os credores internacionais, a equipe econômica de Zélia havia se indisposto com representantes dos bancos privados, com autoridades governamentais e até mesmo com dirigentes de instituições financeiras multilaterais. Ao resguardar-se, muitas vezes de maneira veemente, dos potenciais danos de um acordo aprovado às pressas e à revelia das condições objetivas da economia nacional, o governo criou arestas irreparáveis. Não era novidade que a busca pela autonomia tinha seu preço. Rompida a resistência doméstica com a demissão de Zélia e seus assessores, agora era necessário recuperar a credibilidade do país perante a comunidade financeira internacional. Nesse sentido, a escolha do embaixador Marcílio Marques Moreira, com credenciais no setor financeiro e grande trânsito em Washington, parecia atender a essa necessidade imediata. Embora não fosse uma certeza, tudo indicava que sua nomeação para o superministério da Economia estava ligado ao fracasso das negociações da dívida, como lembra Janio de Freitas:

"Não é mais clara a origem da escolha de Marcílio Moreira, que pode ter sido lembrada pelo embaixador Marcos Coimbra, secretário-geral da Presidência, mas também pode ter fundamento, pelo menos algum, a versão de que atendeu a pressões 
provenientes da dívida externa. Se foi este o caso, a escolha facilitaria para lá e criaria problema para cá’ ${ }^{502}$.

Não havia dúvidas de que Collor estava trocando uma equipe de perfil desenvolvimentista por outra de perfil liberal, em sintonia com a retórica inicial do governo $^{503}$. As ideias de Marcílio, nas palavras de Roberto Campos, não se casavam com o comportamento econômico errático de Collor no primeiro ano, mas com sua plataforma eleitoral. "Com a troca, Collor se redescobriu, reencontrou a si mesmo" 504 . Gilberto Dimenstein corroborava com essa leitura, enfatizando a importância do resgate da credibilidade doméstica e internacional: "Ele tem um perfil que extrapola os limites do presidente, conhecido dentro e fora do país. E justamente por isso acalma os empresários”,505. Além disso, o perfil ideológico do novo ministro representava a conclusão de um processo de favorecimento do grupo liberal-internacionalista do Itamaraty, em marcha desde o início do governo. Nos círculos diplomáticos, Marcílio sofria resistência da ala nacionalista exatamente por sua oposição - muitas vezes frontal - ao terceiro-mundismo ${ }^{506}$.

Mas não se tratava somente de uma questão de credibilidade externa. Collor parecia ter ouvido o conselho do primeiro-ministro português, Cavaco Silva, em visita ao Brasil: para o país voltar a atrair capital estrangeiro não é necessário apenas ter democracia e liberdade, mas também "condições de governabilidade" "507. Por isso mesmo, a chegada dos novos responsáveis pelos rumos da economia marcou uma inflexão no comportamento do próprio presidente da República. Collor aproveitou sua passagem por Madri, onde realizou visita oficial de cinco dias a convite do governo espanhol, para anunciar o "estilo soft" em substituição ao seu característico estilo "bateu, levou" do primeiro ano de mandato ${ }^{508}$.

O novo comportamento tinha dois destinatários específicos: os países de Primeiro Mundo, com os quais o relacionamento do governo já sofria certo desgaste e cujo rosto, a partir de então, seria o de Marcílio; o Congresso e os empresários, a quem Collor havia se habituado a enfrentar, e que já impunham derrotas ao governo (em questões, inclusive, de política externa). Um exemplo marcante foi a derrubada, na Comissão de Ciência, Tecnologia, Comunicação e Informática da Câmara dos Deputados, do projeto de lei do

\footnotetext{
${ }^{502}$ Freitas, Janio de. "A saída e a entrada”. Folha de São Paulo, 10 de maio de 1991, p. 1-5.

503 "Sou um liberal", disse Marcílio na posse. Ver FSP, "Marcílio toma posse e defende entendimento", 11 de maio de 1991, p. 1-6.

${ }^{504}$ FSP, "Para Campos, Collor se reencontrou", 10 de maio de 1991, p. 1-11.

505 Dimenstein, Gilberto. "Yes, nos temos ministro", 11 de maio de 1991, p. 1-2.

${ }^{506}$ FSP, “Ex-ministro de Jango inspira Marcílio", 10 de maio de 1991, p. 1-8.

${ }^{507}$ FSP, "Cavaco Silva dá fórmula para atrair recursos", 10 de maio de 1991, p. 1-5.

${ }^{508}$ OESP, "Collor troca 'bateu, levou' por 'estilo soft"”, 16 de maio de 1991, p. 4.
} 
Executivo que alterava o Plano Nacional de Informática (Planin). O substitutivo aprovado no lugar, enquanto Collor encontrava-se na Espanha, representava um retrocesso em um dos maiores gargalos bilaterais que o Brasil conservava com os Estados Unidos ${ }^{509}$.

As declarações do presidente sobre o "estilo soft" revelava a dupla função da viagem de Collor à Espanha. Se, por um lado, havia o claro interesse de aprofundar as relações com aquele que era considerado um exemplo de sucesso no contexto da integração regional, demonstrava-se também a intenção de utilizar uma viagem internacional como palanque para recados domésticos. As atividades diplomáticas foram realizadas a contento: durante a visita, assinou-se a Ata de Bases do Tratado Geral de Cooperação e Amizade entre Brasil e Espanha $^{510}$, com vistas a aprofundar contatos políticos, culturas e econômicos - esperava-se a ampliação dos investimentos espanhóis, além de um fluxo de negócios na casa dos US\$ 3 bilhões ${ }^{511}$. Para dentro, a mensagem dizia respeito à necessidade de se construir um entendimento nacional - após virtualmente um ano de isolamento e confrontação políticos inspirado nos Pactos de Moncloa ${ }^{512}$. O cenário não era positivo: a evasão de capitais brasileiros aumentava, as reservas cambiais estavam em queda ${ }^{513}$, e crescia a dependência do governo de um pacto com o Legislativo para encaminhar questões ligadas à reforma econômica e à política econômica externa, como os termos da negociação com os credores privados que Zélia não havia conseguido encaminhar. No meio político, alguns já falavam em "sarneyzação" do governo federal ${ }^{514}$, tamanha era a paralisia das relações entre governo e Congresso.

De volta ao Brasil, Collor tinha três tarefas urgentes diante de si ligadas à dívida externa, o tema mais sensível da agenda nacional naquele momento. A primeira era encaminhar um texto preliminar ao Senado do acordo com os credores sobre os atrasados. A proposta, que envolvia o pagamento de US\$ 2 bilhões até o final do ano, e a conversão dos

\footnotetext{
${ }^{509}$ OESP, "Derrota fragorosa", 18 de maio de 1991, p. 3.

510 Disponível em http://dai-mre.serpro.gov.br/atos-internacionais/bilaterais/1991/b_27_2011-10-17-10-44-56/. Acesso em 3/7/2014.

511 OESP, "Lições de Espanha", 18 de maio de 1991, p. 3.

512 Os Pactos de Moncloa representam o esforço concertado de diálogo entre governo, partidos e representantes da sociedade civil espanhola, em fins da década de 1970, no sentido de conduzir a transição democrática na Espanha. Eles "assinalaram o começo de uma concertação social em três faixas paralelas, a saber, o governo, as organizações sociais e os sindicatos. Numa situação econômica tão difícil, marcada pela inflação e recessão, as organizações de trabalhadores aceitaram uma série de restrições salariais, em troca de alguns compromissos assumidos pelo governo e pelos órgãos patronais, no sentido de desenvolver o Estado de Bem-Estar Social". Ver Educação e Conhecimento: a experiência dos que avançaram. Brasília: UNESCO, 2004, p. 305.

${ }^{513}$ De acordo com o relatório International Financial Statistics, do FMI, a evasão de capitais brasileiros chegava a US\$ 17 bilhões em setembro de 1990. Ao mesmo tempo, as reservas cambiais apresentaram uma queda de US\$ 1,1 em março de 1991, sobretudo em função do pagamento de juros, a maior queda desde a posse. Ver FSP, "Brasil já ultrapassa Argentina e Venezuela na evasão de capitais"; "Reservas cambiais caem US\$ 1 bi em março", 22 de maio de 1991, p. 1-8.

${ }^{514}$ Coelho, Marcelo. "Sarneyzismo". Folha de São Paulo, 20 de maio de 1991, p. 1-2.
} 
US\$ 6 bilhões restantes em bônus com prazo de dez anos e três de carência, foi entregue por Marcílio ao senador Mauro Benevides, presidente do Congresso, no fim de maio. Embora os bônus só fossem emitidos após o Brasil negociar com os bancos o destino do estoque da dívida (no valor de US\$ 52,3 bilhões), era necessário começar um diálogo com o Senado em busca de garantias de que o Brasil teria o que apresentar aos credores privados. Collor queria que a questão dos atrasados fosse resolvida no Senado antes de sua viagem a Washington, programada para o dia 18 de junho, de modo a aumentar seu poder de barganha junto aos Estados Unidos.

A segunda (e mais importante) tarefa era oferecer aos bancos um plano de reestruturação da dívida de médio e longo prazos. Simbolicamente, Marcílio escolheu o The Washington Post para divulgar a proposta brasileira, publicada na véspera da viagem presidencial $^{515}$. Pela primeira vez no governo Collor, um "balão de ensaio" sobre a dívida trouxe resultados positivos. Em vez da rejeição (quase automática) dos credores privados às sugestões brasileiras, os bancos consideraram a proposta do ministro um ponto de partida para as negociações. Agradou aos credores, em particular, o abandono do discurso de "capacidade de pagamento", um dos pontos inarredáveis da posição da antiga equipe econômica ${ }^{516}$.

A última tarefa era renovar a equipe de negociação da dívida, muito identificada com a ex-ministra da Economia. Também às vésperas da viagem de Collor aos EUA, Marcílio substitui Jório Dauster - considerado um negociador "intransigente" pelos credores - por Pedro Malan, ex-diretor do Banco Mundial e assessor técnico do BID em Washington ${ }^{517}$. Ao fim daquele mês, o novo grupo negociador" ${ }^{518}$, acompanhado por Dauster, iniciaria um "road show" por Tóquio, Londres, Paris, Frankfurt e Nova York, para negociar com os credores privados $^{519}$. Terminado o périplo entre os países industrializados, Dauster assumiria o cargo de embaixador junto à CEE, em Bruxelas.

Com esses três movimentos - que representavam, em comparação à postura da fase anterior, concessões importantes aos interesses dos credores públicos e privados - Collor muniu-se de bons argumentos para demandar do governo norte-americano apoio na

\footnotetext{
${ }^{515}$ A proposta brasileira envolvia reescalonar a dívida da seguinte maneira: saldar os juros do estoque a vencer nos primeiros três anos após assinado o acordo, com incidência de $40 \%$ da tarifa oficial de juros; $50 \%$ da taxa de juros sobre o montante a vencer no quarto e no quinto ano; discussão sobre um percentual maior que $50 \%$ após o quinto ano.

${ }_{516}$ FSP, "Marcilio faz nova proposta para dívida externa", 15 de junho de 1991, p. 1-8.

${ }^{517}$ FSP, "Marcílio substitui Dauster", 14 de junho de 1991, p. 1-6

518 A missão era composta por Jório Dauster, Pedro Malan, o diretor do Departamento de Assuntos Internacionais do Banco Central, Armínio Fraga, e o chefe do departamento de dívida externa do BC, Sergio Ruffoni Guedes.

${ }^{519}$ Nova York. FSP, “Nova etapa de negociação”, 15 de junho de 1991, p. 1-8
} 
negociação com os bancos, que deveria se iniciar em breve. Sem acesso a novos créditos por parte deles ou do FMI, o presidente brasileiro contava com as mudanças realizadas na equipe e na postura negociadora para amealhar capital político junto a Bush, mesmo sabendo que as condições econômicas não eram favoráveis. No encontro dos presidentes, no dia 18 de junho, Collor expôs as dificuldades domésticas e fez um pedido de ajuda, tendo em vista o sacrifício realizado:

\begin{abstract}
"Temos que ser pacientes. Não podemos simplesmente fazer essas coisas sozinhos. Devemos trabalhar com o Congresso, e não temos maioria (...). Temos projetos de lei pendentes no Congresso relativos a direitos de propriedade intelectual e informática. Fizemos todo o possível nesse sentido. Com relação à dívida, além da renegociação dos atrasados e do montante, queremos saber da possibilidade de novos investimentos. Temos que crescer novamente. Todas essas coisas positivas que fizemos são o resultado de sacrifícios terríveis. O desemprego que temos é tremendo. Estamos sofrendo uma recessão (...). Então no momento em que temos um homem conduzindo nossa economia tão qualificado quanto Marcilio, que foi embaixador aqui, tudo isso me garante que estamos prontos para embarcar numa nova etapa de liderança, ${ }^{, 520}$.
\end{abstract}

A reação do presidente norte-americano à demanda por novos investimentos foi de desdém. Não se mencionou o assunto, em absoluto:

\footnotetext{
"Nas questões comerciais, queremos trabalhar com vocês (...). Queremos levar [a Rodada] Uruguai a uma conclusão exitosa (...). Você mencionou propriedade intelectual. É fundamental que você coloque esforços substanciais nisso. Sabemos o que estão passando, (...) mas temos que trabalhar juntos para termos avanços" ${ }^{\prime 521}$.
}

Na saída do encontro, embora a manifestação oficial de Bush tenha sido positiva - "a América fica do seu lado", disse a Collor -, o Brasil não obteve nenhuma garantia de ajuda para reduzir a dívida externa. Qualquer suporte norte-americano estaria condicionado ao sucesso do ajuste econômico ${ }^{522}$. A posição dos Estados Unidos foi um choque de realidade ao governo brasileiro, mostrando que os recuos não seriam necessariamente correspondidos à altura das expectativas. Isso obrigou o governo a fazer concessões subsequentes, como aceitar a conversão da dívida para projetos de proteção à natureza - o que, até então, estava fora de cogitação -, bem como aceitar as negociações subsequentes da dívida nos marcos institucionais e no leque de opções contempladas no Plano Brady ${ }^{523}$. As críticas à nova postura não tardaram a chegar, como se vê no comentário de Clóvis Rossi:

\footnotetext{
${ }^{520}$ The White House. "Memorandum of Conversation no. 4713".

${ }^{521}$ Idem, p. 3.

${ }^{522}$ FSP, "Collor tem recepção positiva mas EUA condicionam ajuda", 19 de junho de 1991, p. 1-4.

${ }^{523}$ FSP, "Governo aceita a conversão da dívida para projetos ambientais", 21 de junho de 1991, p. 1-7; FSP, "mudanças na dívida", 24 de junho de 1991, p. 1-2.
} 


\begin{abstract}
"Levados às últimas consequências, os recuos com que o presidente da República acenou em sua visita aos Estados Unidos podem reintroduzir na diplomacia brasileira a ideia de que 'o que é bom para os Estados Unidos é bom para o Brasil' (...). No momento em que os Estados Unidos emergem ganhadores do combate ideológico da Guerra Fria, tende a haver tal correria para se tornar amigo do rei que se corre o risco de, em vez de colaboração, aceitar-se a rendição incondicional (...). O que o governo brasileiro necessita, mais do que os aplausos da Casa Branca e dos investidores americanos, é dos aplausos e da confiança interna, até para poder dizer sim ou não aos Estados Unidos, quando convier ao Brasil e não aos Estados Unidos" $" 524$
\end{abstract}

A bem da verdade, o próprio presidente Collor reagiu mal à indisposição norteamericana em ajudá-lo. A viagem aos Estados Unidos foi um divisor de águas, e lhe impôs o abandono - ao menos para fora - do "estilo soft". Logo antes da ida a Washington, um editorial da Folha avaliava que "o estilo 'soft', inaugurado na Espanha, pareceu ter-se aprofundado (...). Em vez do onírico, mas vazio, frenesi primeiro-mundista, o presidente defendeu o ingresso numa etapa menos "romântica e amadorística"" ${ }^{525}$. Outro editorial, publicado dias depois, avaliava a questão de maneira um pouco diferente, a partir das declarações do presidente: "Resumindo o principal dilema do front externo, Collor foi enfático: cabe ao Brasil viabilizar-se, criar condições para atrair capitais e daí garantir seu crescimento. Acabou a fase em que o país 'ficava sentado esperando, achando que todo mundo lhe deve homenagens e tem que ajudar",526.

No contexto das negociações da dívida, contudo, as concessões continuavam sendo feitas e geravam desencontros dentro do próprio governo. O descolamento entre as conversas com os credores e as instituições financeiras, conduzidas por Marcílio e sua equipe, e o tom da política externa em geral, abre espaço para desenvolvimentos erráticos. Após a declaração do ministro da Economia de que aceitaria a conversão da dívida em projetos ambientais, por exemplo, outros membros do primeiro escalão manifestaram-se a respeito de maneira contrária. Para o ministro da Justiça, Jarbas Passarinho, a conversão da dívida externa em investimentos na área ambiental poderia representar uma ameaça à soberania nacional, pois representava uma tentativa de "planetarização" da Amazônia ${ }^{527}$. O chanceler Francisco Rezek, por sua vez, criticou os números oferecidos para a conversão da dívida, qualificandoos de "medíocres" e sugerindo que deveriam ser maiores, ainda mais quando se pensa na dimensão da área que se quer preservar e no montante da dívida. "Constrangem-nos as cifras

\footnotetext{
${ }^{524}$ Rossi, Clóvis. “O que é bom para quem”. Folha de São Paulo, 22 de junho de 1991, p. 1-2.

${ }^{525}$ FSP, “A entrevista de Collor”, 18 de junho de 1991, p. 1-2.

${ }^{526}$ FSP, "Outro presidente", 21 de junho de 1991, p. 1-2.

${ }^{527}$ FSP, "Pressões ambientalistas sobre a Amazônia preocupam o governo", 26 de junho de 1991, p. 1-8.
} 
pela qual (sic) a questão é tratada atualmente, esperamos que haja uma modificação no tratamento futuro da conversão" ${ }^{, 528}$.

No Congresso, as vitórias do governo eram relativas. Por um lado, o Senado autorizou o ministério da Economia a celebrar operação de natureza financeira com os credores externos, aprovando o projeto referente ao cronograma do pagamento dos atrasados da dívida com os bancos. Foi a primeira vez, desde que estabelecida a autorização legislativa para esse tipo de transação na Constituição de 1988, que o governo pôde restabelecer relações com os credores privados $^{529}$. Por outro lado, os congressistas apertavam os critérios de conversão da dívida em projetos ecológicos, o que reduzia a margem de manobra da equipe econômica, e exigiam do governo a manutenção do conceito de "capacidade de pagamento", previamente abandonado por Marcílio em Washington ${ }^{530}$.

Apesar dos percalços, as negociações seguiram nos meses subsequentes. Embora ainda não se tivesse chegado a um acordo sobre o cronograma do pagamento dos atrasados, a primeira parcela acertada com os bancos foi finalmente realizada, de maneira unilateral, no dia $1^{\circ}$ de julho, no valor de US\$ 875 milhões. No mesmo dia, Collor lançou o programa piloto de conversão da dívida em projetos de preservação, com limite de conversão estabelecido em US\$ 100 milhões ${ }^{531}$. Uma semana mais tarde, o Marcílio vai a Washington e apresenta às autoridades americanas - Nicholas Brady e David Mulford - o compromisso brasileiro em direção à normalização do relacionamento com a comunidade financeira internacional. Os oito pontos apresentados pelo ministro da Economia foram: austeridade monetária e tributária, reforma estrutural e fim do 'entulho burocrático', intensificação do processo de privatização, consolidação da abertura comercial, saída ordenada do congelamento, normalização das relações com os credores internacionais e modernização do país ${ }^{532}$.

O entendimento amplo com a comunidade financeira internacional dependia, além dos compromissos retóricos, da resolução de três outros pontos de estrangulamento: a mudança de

\footnotetext{
${ }^{528}$ FSP, "Rezek quer mais recursos para a conversão da dívida exterana”, 22 de junho de 1991, p. 1-4.

${ }^{529}$ O placar, no Senado, foi de 61 votos a favor, seis contra e uma abstenção. Eduardo Supicy (PT-SP) foi um dos que votou contra. Entre as discordâncias de Suplicy, estava exatamente a questão do interesse nacional. Para ele, o governo não demonstrou "que a capacidade interna de pagamentos da economia brasileira, definida como 'a diferença positiva entre as receitas e as despesas da administração pública federal direta e indireta, excluídas as das instituições financeiras federais', seja compatível com os compromissos assumidos". Ver Suplicy, Eduardo Matarazzo. “O acordo dos juros atrasados”. Folha de São Paulo, 23 de junho de 1991, p. 1-3.

${ }^{530}$ Em reunião com senadores FHC (PSDB-SP), Humberto Lucena (PMDB-PB), Mauricio Correa (PDT-DF) e Ney Maranhão (PRN-PE) e o líder do governo no senado, Marco Maciel (PFL-PE), o governo decidiu que não vai usar as operações de conversão como instrumento para reduzir o estoque da dívida externa. Conversões seguirão parâmetros muito rígidos em casos excepcionais para privatizações de estatais e projetos ecológicos. O conceito de capacidade de pagamento continuará servindo como parâmetro para os acordos. FSP, "Governo quer conversão da dívida sob controle", 29 de junho de 1991, p. 1-8.

${ }^{531}$ FSP, "Collor aprova plano piloto para conversão", 2 de julho de 1991, p. 1-11.

${ }^{532}$ FSP, "Marcílio apresenta a Brady os principais pontos de sua política", 9 de julho de 1991, p. 1-4.
} 
postura em relação às barreiras comerciais junto ao GATT; o restabelecimento das relações com o FMI; e a aprovação da proposta brasileira sobre os atrasados e o início da negociação do principal da dívida com os bancos, agora conduzida por Pedro Malan.

As concessões no comércio multilateral vieram quase que imediatamente. No dia 12 de julho, o Brasil tomou a decisão unilateral de renunciar ao direito de aplicar restrições às importações para manter o equilíbrio de seu balanço de pagamentos, previsto no artigo 18-B do GATT. A medida brasileira foi bem recebida pelo Conselho de Representantes do GATT. Para Arthur Dunkel, diretor-geral do GATT, o comunicado brasileiro representava "uma confirmação das abrangentes reformas comerciais que estão acontecendo no Brasil" e demonstram determinação do país em "continuar abrindo sua economia". A declaração do embaixador brasileiro no GATT, Rubens Ricupero, seguiu a mesma linha:

\footnotetext{
“embora persistam consideráveis dificuldades no balanço de pagamentos, essencialmente em decorrência dos compromissos com o serviço da dívida externa, o Brasil decidiu deixar de utilizar o Artigo XVIII B como uma prova de seu compromisso com a liberalização do comércio (...), [sendo] a última de uma expressiva série de ações radicais e - por que não dizer - corajosas empreendidas por muitos países em desenvolvimento para mostrar seu comprometimento com o comércio multilateral"
}

Os outros dois pontos envolveriam uma delicada engenharia de coordenação de posições. Tratava-se, afinal, de uma negociação de simultânea com os credores e com o FMI, sendo que o resultado de uma impactava diretamente sobre a condução da outra. Sem a retomada do diálogo com o FMI, inviabilizava-se o acordo com os bancos. Ao mesmo tempo, sem uma garantia aos bancos, as autoridades multilaterais não liberariam empréstimos ao Brasil. Havia um risco considerável de se fazerem concessões aos credores privados, por exemplo, sem a segurança de que o governo usufruiria do aporte de recursos de curto prazo do mundo. O resultado poderia ser a deflagração de um surto inflacionário, tendo em vista a uma situação macroeconômica instável e uma condição fiscal negativa com que o Brasil iniciava a negociação. Para Paulo Nogueira Batista Jr., melhor seria ganhar tempo com os credores e aguardar condições melhores para o restabelecimento das conversas ${ }^{534}$. Mas as condições políticas do país não davam espaço para que isso acontecesse no timing adequado.

Por isso mesmo, o Brasil buscou retomar, às pressas, as negociações da dívida com o Fundo Monetário Internacional, no dia 16 de julho. Sem o acerto formal com o Fundo, o governo brasileiro não conseguiria normalizar suas relações com a comunidade financeira

\footnotetext{
${ }^{533}$ FSP, "Gatt elogia renúncia do país a restringir importações”, 13 de julho de 1991, p. 1-7

${ }^{534}$ FSP, "Ex-assessor de Funaro vê risco de hiper", 15 de julho de 1991, p. 1-5.
} 
internacional, prosseguir as negociações com os credores privados e retomar os empréstimos com o Banco Mundial e com o BID. A missão do FMI enviada ao Brasil, coordenada pelo chefe da Divisão do Atlântico, Thomas Reichmann, contava com a participação de oito técnicos do FMI (o dobro do que usualmente se enviava a países em negociação). Reichmann aproveitou a vinda a Brasília para apresentar ao governo brasileiro seu sucessor, José Fajzenbaum $^{535}$. Para o público interno, a vinda de técnicos do Fundo poderia gerar reações negativas, dadas as memórias de relações difíceis que alguns governos tiveram na busca de conciliar as exigências recessivas e as necessidades domésticas (como havia sido o caso de JK ou Figueiredo). Desde 1987, quando a moratória foi decretada, o Brasil não recebia créditos multilaterais $^{536}$.

\subsubsection{Sai o 'estilo soft', entra o terceiro-mundismo}

As novas tratativas com o Fundo Monetário e as concessões feitas na Rodada Uruguai levaram Collor a abandonar o "estilo soft" na política externa. Tratava-se do início de uma nova etapa, ao menos no plano retórico, em que o desejo de integração ao Primeiro Mundo dava lugar a um sentimento urgente de independência. Um mês após a desilusão norteamericana, a inflexão no discurso ficava patente, operando como uma espécie de mecanismo compensatório para fins primordialmente domésticos. Às vésperas de viajar para Guadalajara, no México, onde seria sediada a Primeira Cúpula Ibero-Americana, Collor concedeu uma longa entrevista no Palácio do Planalto ao periódico mexicano Excelsior. Nela, o presidente resumiu as posições que seriam defendidas pelo Brasil no encontro, tendo suas declarações se transformado numa espécie de síntese do direcionamento renovado de sua política externa. $\mathrm{O}$ trecho que ganhou destaque e repercutiu na mídia nacional fazia referência a uma "nova conformação geopolítica do mundo" - marcada, entre outras coisas, pela formação de grandes blocos econômicos e pela "democratização irreversível” da América Latina. A referência veio após uma pergunta sobre o futuro e a concretização da integração latino-americana e foi desenvolvida extensamente:

\footnotetext{
"O fim do mundo bipolar do ponto de vista ideológico fez-nos crer que afinal se tornará vitoriosa a tese liberal-social do respeito aos direitos humanos e às liberdades democráticas - e que, a partir daí, haveria paz e tranquilidade em um mundo multipolar. Infelizmente, aquele mundo ideologicamente bipolar foi
}

\footnotetext{
${ }^{535}$ FSP, "País reinicia negociações com o FMI", 16 de julho de 1991, p. 1-4.

${ }^{536}$ Almeida, Paulo Roberto de. Relações internacionais e política externa do Brasil: a diplomacia brasileira no contexto da globalização. Rio de Janeiro: LTC, 2012, p. 146.
} 
sucedido por outro mundo bipolar, com abismos de desenvolvimento e prosperidade, agravados pela formação de megablocos cada vez mais protecionistas. Diante da destruição de Cartago, Catão perguntou: “O que será de Roma sem seus inimigos?". Eu me pergunto: o que acontecerá no enorme espaço vazio provocado pelo fim da bipolarização ideológica, com o aparecimento desse grande império, o Império do Norte, absolutamente só, absolutamente rico, detentor das formas mais avançadas do conhecimento e sem nenhum contraponto? Não coloco o Sul como inimigo do Norte. Aposto na solidariedade. Mas devemos debater como o Norte pode colaborar para diminuir as gritantes distorções com o Sul, que engloba três quartos da humanidade" ${ }^{, 537}$.

O discurso de Collor pode ser compreendido sob três diferentes ângulos. A guinada retórica rumo ao terceiro-mundismo e à denúncia sistemática do "Império do Norte" poderia trazer algum tipo de dividendo doméstico, principalmente porque a esperança de muitos no projeto liberal do início do governo já tinha se esvaído. Paradoxalmente, já se chegava a pedir o retorno de Zélia à equipe econômica ${ }^{538}$. Pode-se interpretar o discurso, alternativamente, como um balão de ensaio em direção à diversificação das parcerias estratégicas brasileiras, sobretudo fora do hemisfério (como os países ibéricos, por um lado, ou mesmo aqueles fora do eixo desenvolvido que ainda se identificavam com o tipo de discurso apropriado por Collor). Por fim, ligado à segunda interpretação, é possível asseverar que a retórica inflamada era uma maneira que o Brasil, tendo fracassado em sua guinada modernizadora, tinha de reaver sua identidade própria vis-à-vis os demais países da região, que caminhavam de maneira mais decidida em direção aos Estados Unidos e às reformas do Consenso de Washington.

Não obstante, no eixo do relacionamento com a comunidade financeira internacional, onde se encontravam as grandes dificuldades da inserção brasileira, pouco mudaria. As concessões articuladas nos bastidores eram mais relevantes que as palavras do presidente em viagem. O que não se esperava era que Collor transportasse seu discurso contra autoridades específicas do Fundo Monetário Internacional - especialmente quando elas estivessem em solo brasileiro. Na primeira entrevista de Fajgenbaum como a nova autoridade responsável pela delegação no Brasil, no dia 17 de julho, ele ressaltou a necessidade de que o Brasil realizasse reformas estruturais, que envolveriam mudanças na Constituição, para obter créditos de longo prazo com o FMI ${ }^{539}$. A declaração foi tomada como afronta: "Se guardarmos a serenidade, [trata-se de] algo muito parecido com desaforo", afirmou Jânio de

\footnotetext{
${ }^{537}$ OESP, "Collor defende colaboração Norte-Sul”, 17 de julho de 1991, p. 4, grifo nosso.

${ }^{538}$ De acordo com pesquisa feita pelo Ibope entre 20 e 28 de agosto, $49 \%$ dos entrevistados querem a volta da ex-ministra Zélia e sua equipe, enquanto $30 \%$ são contra. A pesquisa mostra que, para os brasileiros, as áreas nas quais o País enfrenta problemas mais graves são as dos salários dos trabalhadores, do desemprego e da saúde. O Globo, "Ibope apura que os brasileiros querem Zélia no Governo Collor", 07 de setembro de 1991, p. 4.

539 JB, "FMI exige que Brasil faça mudanças na Constituição", 18 de julho de 1991, p. 3.
} 
Freitas. "Por mais condicionada que seja de fato, a soberania nacional é um tabu resistente e, se possível dizer assim, um sentimento sensível. Fajgenbaum começou por refutar o mito. É lógico que experimente a força do sentimento" ${ }^{\text {}} 40$.

As reações, pois, foram proporcionais. O Ministério da Economia entrou em contato diretamente com o FMI em Washington para protestar contra as declarações do novo chefe da Divisão do Atlântico Sul. A resposta vocal do governo brasileiro foi uma tentativa de mostrar à opinião pública, principalmente ao Congresso Nacional, que não se subordinaria às teses do FMI. As declarações de Marcílio e seus assessores, contudo, buscavam manter o baixo perfil necessário à continuidade das negociações. Mas, ao saber das declarações, Collor sugeriu que o técnico do FMI - a quem chamou de "serviçal" Brasil. Para O Globo, o estilo "soft" voltava a dar lugar ao "bateu, levou". Com efeito, a controvérsia em torno do posicionamento do representante do Fundo Monetário levou à interrupção temporária das negociações com o governo brasileiro ${ }^{542}$. No dia 23 de julho, após a notícia sobre a ruptura das negociações com o FMI, o Estadão disparou, em editorial: "A bandeira do anti-imperialismo voltou a ser hasteada na sede do governo brasileiro (...). Podese perceber a influência dos que, (...) na sede do Itamaraty, desejam conduzir a política externa para o rumo ditado por sua estreita visão terceiro-mundista",543

\subsubsection{O longo caminho das negociações}

A partir desse momento, as negociações com o FMI vão ficando cada vez mais truncadas. $\mathrm{O}$ acordo stand-by buscado pelo Brasil desde o início das negociações, no ano anterior, ainda não tinha sido garantido. Somente em 9 de agosto vem a notícia de Nova York que $95 \%$ dos bancos credores haviam aceitado os termos propostos pelo Brasil na oferta realizada em junho. No dia 21 de agosto, a delegação de negociadores brasileiros finalmente apresentou sua proposta para a renegociação do principal da dívida com os bancos privados cotada em US\$ 52 bilhões -, que envolvia a securitização do débito. Proposta semelhante havia sido apresentada por Bresser-Pereira, em 1987, mas a notícia vazou antes da reunião e o então secretário de Tesouro James Baker a considerou inaceitável. A proposta atual, em contraste, busca um meio-termo: nem inaceitável, nem totalmente palatável aos interesses dos

\footnotetext{
${ }^{540}$ Freitas, Jânio de. "Missão de desacordo", 20 de julho de 1991, p. 1-5.

${ }^{541}$ No dia seguinte, Rezek rebateu as críticas à reação de Collor contra o chefe da missão do FMI. "Foi uma pura lembrança de regras internacionais. Com muita espontaneidade, à maneira do presidente". Ver a coluna "Painel", da Folha de São Paulo, 23 de julho de 1991, p. 1-4.

${ }^{542}$ FSP, "Brasil suspende negociações com chefe da missão do FMI”, 23 de julho de 1991, p. 1-4.

${ }^{543}$ OESP, “A bravata dominical”, 23 de julho de 1991, p. 3.
} 
credores $^{544}$. Nesse caso, contudo, foram tantas as concessões em comparação às propostas aventadas anteriormente que até mesmo os bancos credores se surpreenderam com as demandas brasileiras, abaixo do que eles próprios estariam dispostos a aceitar. Ainda assim, os credores não aceitaram todo o projeto brasileiro, sobretudo porque o país não abria mão de manter reservas para garantir o pleno desenvolvimento da economia. Esse, aliás, era um dos pontos que o Senado não permitiria que o governo abrisse mão ${ }^{545}$.

O novo impasse com os bancos fez com que, no início de setembro, Marcílio saísse em campanha diplomática numa viagem de nove dias entre Nova York, Paris e Tóquio. Sua intenção era manter contatos com os países credores, membros do Clube de Paris, além de autoridades do Fundo Monetário. O Brasil não tinha mais condições de ceder e a crise política doméstica tornava qualquer negociação com o Congresso desgastante e imprevisível. O desejo da equipe econômica era, portanto, angariar o apoio político necessário entre as nações industrializadas para conseguir, do FMI, o tão desejado acordo stand-by sem os quais a negociação com os bancos privados ficaria comprometida. As palavras de Gesner Oliveira descrevem bem a situação:

\begin{abstract}
"Não deixa de ser curioso traçar paralelos com a gestão do ex-colaborador e admirador de Dantas, Marcílio Marques Moreira (...). Dantas gastou boa parte de seu tempo tentando convencer céticos credores externos que o Brasil estava entrando nos eixos. Internamente, enfrentou fortes críticas da esquerda radical, que o acusava de ter vendido o país; enquanto isso, a direita começava a articular um golpe contra o governo, ${ }^{, 54}$
\end{abstract}

No fim, a crise política - que se traduzia em paralisia legislativa e no fracasso de aprovação de reformas constitucionais necessárias ao ajuste econômico, corporificadas no chamado "Emendão" - acabou por estimular em vez de frustrar completamente o diálogo sobre a dívida. Percebendo que as intenções da equipe econômica eram genuínas e que o governo não possuía condições políticas de forçar seus próprios interesses sobre o Congresso, o Fundo Monetário Internacional criou condições para que um acordo fosse fechado com eles antes que se resolvesse a pendência dos bancos. Em 2 de dezembro, o diretor-gerente do FMI, Michel Camdessus, vem ao Brasil receber a carta de intenções redigida por Marcílio, que previa inflação de $2 \%$ para 1992 - em contraste ao quadro hiperinflacionário que voltava a se desenhar em fins de $1991^{547}$.

\footnotetext{
${ }^{544}$ FSP, "País vai propor securitização da dívida", 19 de agosto de 1991, p. 1-4. Para ver o teor específico da proposta, ver FSP, "Brasil apresenta proposta para a dívida", 22 de agosto de 1991, p. 1-13.

${ }^{545}$ FSP, "País pede desconto baixo para a dívida", 26 de agosto de 1991, p. 1-7.

${ }^{546}$ Oliveira, Gesner. "Marcílio à la Dantas". Folha de São Paulo, 31 de outubro de 1991, p. 1-6.

${ }^{547}$ FSP, "Carta ao FMI prevê até fim de 92 inflação de 2\%”, 29 de novembro de 1991, p. 1-5.
} 
O compromisso brasileiro junto ao FMI somente foi aprovado dois meses mais tarde, em 30 de janeiro de $1992^{548}$. No fim do mês seguinte, o Brasil fechou acordo de renegociação da dívida com o Clube de Paris, que previa o refinanciamento de US\$ 11 bilhões do total devido (US\$ 21 bilhões), comprometendo-se a pagar US\$ 4,1 bilhões até o final de 1993. Dados os termos do acordo, Marcílio chegou a admitir que o governo poderia adotar a dolarização da economia depois de implementadas as reformas estruturais propostas pelo governo $^{549}$. Ao longo de todo o ano anterior, a dolarização não era sequer cogitada pelo ministro da Economia, uma vez que representava um constrangimento expressivo à retomada do crescimento e à formulação das políticas macroeconômicas ${ }^{550}$. Não obstante, vale destacar que as concessões realizadas - derrotas, sem a menor dúvida, nos parâmetros anteriores à chegada de Marcílio - acabaram permitindo a inversão natural da ordem da negociação, como destaca o próprio ministro:

\begin{abstract}
"O interessante também, naquela época, era a sequência das negociações. Uma vez feito o acordo com o Fundo, uma vez feito o acordo com o Clube de Paris, podia-se partir para um acordo da dívida. Na sequência anterior, para se ter um acordo com o Fundo ou com o Clube de Paris, era preciso já ter pago aos credores privados ou, ao menos, acordado um esquema para fazê-lo. E isso não ocorreu. É interessante ainda que as negociações tenham prosseguido a despeito de, infelizmente, desde o primeiro trimestre de 1992, não termos conseguido alcançar as metas do Fundo" ${ }^{551}$
\end{abstract}

De fato, as negociações com os bancos ainda se arrastaram por todo o primeiro semestre de 1992. A primeira versão do acordo com os credores privados, rascunhada por Pedro Malan, veio somente no dia 9 de julho daquele ano. O molde da proposta se assemelhava com as de México, Venezuela e Argentina. Somente no dia 21 de setembro, oito dias antes do afastamento de Collor, o governo concluiu a negociação preliminar com os bancos. O termo final só viria um ano e meio mais tarde, em 15 de março de $1994^{552}$. Àquela altura, o projeto de política externa de Collor já havia sido sepultado.

\title{
5.3. As tecnologias de uso dual
}

No capítulo anterior, discutiram-se os efeitos do início do conflito no Golfo Pérsico sobre o complexo industrial-militar brasileiro. As relações entre Brasil e Iraque no campo de

\footnotetext{
${ }^{548}$ FSP, "FMI aprova carta de intenções do Brasil", 30 de janeiro de 1992, p. 1-8.

549 FSP, "Brasil fecha acordo com Clube de Paris", 27 de fevereiro de 1992, p. 1-7

550 Schwartz, Gilson. "Acordo com o Fundo Monetário cria a dolarização burocrática". Folha de São Paulo, 12 de dezembro de 1991, p. 1-4.

551 Moreira, 2001, p. 310-1.

552 Idem, p. 315.
} 
tecnologias sensíveis, especialmente aquelas ligadas à questão nuclear, chamaram a atenção de espectadores internacionais, em particular entre as potências ocidentais, como Estados Unidos e Alemanha. Embora a assistência brasileira ao regime de Saddam Hussein fosse, no limite, bem menor que aquela oferecida pelas nações industrializadas, foi colocada em marcha uma política de restrições à transferência de tecnologia para o governo brasileiro. Logo após a invasão do Kuwait, o governo Bush bloqueou temporariamente a devolução ao Brasil de componentes de motor para o programa de Veículos Lançadores de Satélites (VLS) a que estava sendo dado tratamento térmico por uma empresa norte-americana. Além disso, os Estados Unidos recusaram-se a autorizar a venda de equipamentos de plataforma inercial ao programa brasileiro, bloquearam a venda de supercomputadores à Embraer ${ }^{553}$ e articularam pressões políticas contra países como a França para não transferir ao Brasil tecnologia sensível ligada a mísseis ${ }^{554}$.

A política norte-americana forçou uma mudança no relacionamento entre o governo Collor e o setor bélico nacional. Até meados de 1990, o novo presidente conferiu amplo apoio à exportação de armas e material militar, a ponto de o presidente da Avibrás declarar que "em quatro meses, Collor fez muito mais pela indústria de defesa do que fez Sarney em cinco $\operatorname{anos} " 555$. A crise no Oriente Médio precipitou a guinada em direção ao distanciamento do Iraque, por um lado, e ao desenvolvimento de diretrizes que limitassem a transferência de tecnologia sensível, por outro. Diante das pressões dos EUA, os laços comerciais com o Iraque foram praticamente encerrados, bem como a venda de material bélico ao Irã - que tinha o potencial de substituir o regime de Saddam Hussein como comprador preferencial de bens e serviços militares, de helicópteros a desenvolvimento de mísseis ${ }^{556}$. Ao mesmo tempo, o Planalto não impôs quaisquer restrições às exportações de foguetes terra-terra e de lançadores Astros-2, da Avibrás, para os exércitos da Arábia Saudita e do Qatar ${ }^{557}$.

Deve-se ressaltar que nem todas as decisões da administração Collor sofreram oposição aberta pelas Forças Armadas, embora algumas delas tenham enfraquecido, de fato, a capacidade dos militares em definir e conduzir as políticas no setor de defesa. Não obstante, em algumas questões específicas, os militares uniram-se para vetar iniciativas governamentais que poderiam representar uma redução de sua autonomia setorial. Foi o caso, por exemplo, de uma tentativa de negociação de um acordo de cooperação em defesa com os Estados Unidos,

\footnotetext{
${ }^{553}$ FSP, "Collor descarta na ONU os testes nucleares", 25 de setembro de 1990, p. A-8.

${ }^{554}$ Conca, Ken, 1992, p. 155-6.

${ }^{555}$ Isto É/Senhor, "Fora do ar", 15 de agosto de 1990, p. 23.

${ }^{556}$ FSP, "EUA sabem de comércio com Irã há quatro anos", 9 de abril de 1991, p. 1-8.

${ }^{557}$ FSP, "Governo veta venda ao Iraque", 9 de abril de 1991, p. 1-8.
} 
aventada em abril de 1991 e que seria encaminhada na viagem do presidente a Washington, programada para junho. A diretoria da Associação Brasileira das Indústrias de Material de Defesa (Abimde), ao saber da intenção do governo em aprovar um mecanismo bilateral de "troca de conhecimentos militares", começou a se articular com as FFAA para evitar aquilo que foi temido como uma nova versão do Acordo Militar Brasil-EUA, que vigorou entre 1952 e $1977^{558}$.

Dias mais tarde, a Abimde lançou um documento, enviado ao presidente e aos ministros das três armas, para protestar contra o suposto desejo de Collor de aproximar-se dos EUA em assuntos militares. Intitulado $A$ "Pá de Cal", ou o Início e Fim de um Setor Industrial, o texto listava seis causas básicas que conduziram à crise no setor de defesa: (1) a falta de verbas para as FFAA, que impedem encomendas na indústria nacional; (2) a recessão no mercado global de armamentos; (3) defasagens cambiais que comprometeram as exportações armamentistas; (4) a atuação de "setores políticos radicais" que demonstram preconceito contra a indústria bélica; (5) interesses externos que lutam para acabar com o setor de defesa brasileiro; (6) a transferência, para outras áreas do governo, de recursos originalmente destinados aos militares ${ }^{559}$. Contemplando elementos domésticos e externos, o documento revela, a partir de uma perspectiva setorial, o enfraquecimento dos laços entre o governo Collor e as forças armadas - que vinham, desde a posse, caminhando com certa estabilidade e respeito mútuo ${ }^{560}$. Coisa semelhante havia ocorrido na relação entre empresariado e governo, em fins da década de 1980, cujo desmoronamento foi parcialmente responsável pelo colapso do modelo nacional-desenvolvimentista ${ }^{561}$.

Essa situação explica certos desencontros entre governo e Forças Armadas, como aquela observada em fins de abril de 1991, no mesmo contexto da publicação do documento da Abimde. Pela primeira vez no governo Collor, uma autoridade militar traçava o "quadro de

\footnotetext{
${ }^{558}$ FSP, "Indústria bélica teme novo acordo Brasil-EUA", 9 de abril de 1991, p. 1-8. Para detalhes do Acordo Militar Brasil-Estados Unidos, ver Cervo e Bueno, 2002.

${ }^{559}$ FSP, "Governo faz plano para indústria bélica”, 20 de abril de 1991, p. 1-5.

560 "No plano das relações com as instituições do Estado e do sistema político, o aparelho militar viveu uma situação paradoxal durante o governo do presidente Collor. Submetido a um imprevidente corte de recursos orçamentários, ressentiu-se de uma definição de sua missão que se mostrasse capaz de gerar solidariedade corporativa mesmo na adversidade material e financeira. Ainda assim, as Forças Armadas colaboraram de modo decisivo para a estabilidade política do regime democrático na sua maior prova até aqui ocorrida que foi precisamente o impeachment do presidente Collor. A explicação aponta para o peso do papel dos ministros militares, que se orientaram pelo cumprimento puro e simples da Constituição, dissociando da crise institucional a crise da identidade militar e, em especial, a questão salarial que é por natureza potencialmente desestabilizadora". Oliveira, Eliézer Rizzo de. De Geisel a Collor: forças armadas, transição e democracia. Campinas: Papirus, 1994, p. 215-6.

${ }^{561}$ Sallum Jr., 1995, op. cit.
} 
adversidades em torno do qual se poderia constituir uma unidade no plano intramilitar"562, demonstrando um potencial de reação militar contra o próprio governo. Em seu discurso de despedida do comando do Estado-Maior das Forças Armadas (EMFA), o general Jonas de Moraes Correia Neto denunciou que os militares sofriam uma "campanha adversa", com a finalidade de "desvalorização, ridicularização e desmoralização" dos membros da caserna, alegando que a campanha vinha tanto de membros do governo, que vinham impondo severas restrições orçamentárias e salariais às Forças, quanto dos "países do chamado Primeiro Mundo", que atacam o Brasil por supostas infrações que esses países são "os mais pródigos em cometer"563.

Como forma de manter o delicado equilíbrio entre as contínuas pressões internacionais e domésticas com relação aos assuntos militares, a estratégia de Collor envolveu duas ações simultâneas: favorecer, internamente, os interesses das Forças Armadas e limitar, externamente, a submissão total brasileira aos regimes internacionais de controle de tecnologia de uso ambivalente. No primeiro caso, vê-se, por exemplo, a disposição do presidente da República em tomar partido dos ministros militares em sua disputa com o Poder Legislativo em torno de reajustes salariais à carreira castrense. Documento assinado pelos três ministros militares - Carlos Tinôco (Exército), Mário César Flores (Marinha) e Sócrates Monteiro (Aeronáutica) - e publicado no dia 3 de julho de 1991 condenava a rejeição, pelo Congresso, da MP 296, que corrigia o soldo dos militares, e o concomitante aumento de $38 \%$ conferido aos servidores legislativos. Ampliava-se, na visão das FFAA, “o injustificável e inconstitucional fosso salarial que separa os militares e a grande maioria dos servidores civis do Executivo dos servidores do Legislativo e do Judiciário" ${ }^{564}$. Ao tomar parte de seus ministros militares em prejuízo das relações com o Congresso, Collor sinalizou a centralidade do apoio militar a seu governo e buscou sustentar o tênue equilíbrio de forças políticas que o circundavam. Alguns parlamentares chegaram a falar, com certo temor, do risco de se restaurar a "tutela militar", como foi o caso do deputado Nilmário Miranda (PT-MG), ao manifestar que "o presidente deveria tomar cuidado ao se valer dos militares para atacar o Congresso num momento em que esse ataque lhe interessa" $"$.

No plano externo, Collor de Mello buscou reiterar ao governo Bush sua disposição de dirimir as desconfianças internacionais com relação às tecnologias de uso dual, especialmente a nuclear. Na viagem que realizou a Washington em junho, o presidente brasileiro

\footnotetext{
562 Oliveira, 1994, p. 215.

${ }^{563}$ FSP, “General diz que há campanha contra militares", 20 de abril de 1991, p. 1-5.

${ }^{564}$ O Globo, "Desnível salarial leva Forças Armadas a criticar Congresso", 3 de julho de 1991, p. 1.

565 O Globo, "Militares temem início de tutela", 4 de julho de 1991, p. 3.
} 
comprometeu-se a assinar um acordo de salvaguardas nucleares com a Agência Internacional de Energia Atômica (AIEA). Ademais, Collor reforçou que havia enviado, pouco tempo antes, um projeto de lei ao Congresso Nacional garantindo que nenhuma pessoa que trabalhou para o governo e tivesse acesso a informação secreta ou ultra-secreta poderia cooperar com outros governos em questões sensíveis. A única ressalva na conversa com o presidente Bush era garantir que as inspeções nucleares realizadas nas instalações brasileiras, quando colocadas em vigor, não comprometeriam os segredos industriais - ponto que foi colocado pelo secretário Goldemberg e aparentemente aceito pela comitiva norte-americana ${ }^{566}$.

O tema nuclear já vinha sendo encaminhado, paralelamente, no nível das relações bilaterais Brasil-Argentina. Ainda no governo Sarney, foram diversos instrumentos firmados no sentido de promover uma integração nuclear, que estabelecesse salvaguardas próprias, intercâmbio e cooperação para fins exclusivamente pacíficos: as declarações de Foz do Iguaçu (30 de novembro de 1985), Brasília (10 de dezembro de 1986), Viedma (17 de julho de 1987), Iperó (8 de abril de 1988) e Ezeiza (30 de novembro de 1988) ${ }^{567}$. De todas elas, a Declaração de Iperó ${ }^{568}$ é considerada o mais expressivo ato político, pois abriu espaço à discussão de um novo Tratado de Tlatelolco, estendendo a possibilidade de cooperação nuclear "a todos os países latino-americanos que estejam interessados em dela participar”.

Desde o início do governo Collor, tomaram-se passos concretos para consolidar a integração nuclear, acelerados pelas cambiantes circunstâncias internacionais e pela crescente desconfiança quanto às intenções brasileiras nesse campo. Como nota o embaixador Everton Vargas, no novo governo "a questão nuclear deixou de ser associada à busca da autonomia tecnológica, como o fora durante o período militar e sob o Governo Sarney. A preocupação maior era com o acesso à tecnologia, e procurava-se um tratamento multilateral mais transparente que legitimasse essa opção" ${ }^{\text {569 }}$. Essa parece também ter sido a opção argentina, cuja orientação internacional, sob o governo Menem, aproximava-se daquilo que Carlos Escudé denominou realismo periférico ${ }^{570}$. Embora motivados por circunstâncias sutilmente distintas (o Brasil não chegou, como se sabe, ao grau de alinhamento ou adesão aos EUA que chegou a Argentina de Menem, di Tella e Cavallo), ambos os países lograram um duplo ganho com a aproximação nuclear: sinalizavam para os Estados Unidos seu compromisso

\footnotetext{
${ }^{566}$ The White House. Memorandum of Conversation no. 4713, 18 de junho de 1991, p. 4.

${ }^{567}$ Oliveira, Odete Maria de. "A integração bilateral Brasil-Argentina: tecnologia nuclear e Mercosul”. Revista Brasileira de Política Internacional, vol. 41, no. 1, 1998.

${ }^{568}$ República Federativa do Brasil. Declaração de Iperó, 8 de abril de 1988. Disponível em http://daimre.serpro.gov.br/atos-internacionais/bilaterais/1988/b_19/. Acesso em 11/10/2014.

${ }^{569}$ Vargas, Everton Vieira. "Átomos na integração: a aproximação Brasil-Argentina no campo nuclear e a construção do Mercosul”. Revista Brasileira de Política Internacional, vol. 40, no. 1, 1997, p. 55.

${ }^{570}$ Escudé, Carlos. Foreign Policy Theory in Menem's Argentina. New Haven: Yale University Press, 1990.
} 
com a não-proliferação e o desenvolvimento tecnológico para fins exclusivamente pacíficos, por um lado, e abriam caminho para o aprofundamento de outras modalidades de integração regional, em particular a econômica, por outro.

O primeiro ato bilateral no campo nuclear sob Collor e Menem data de 28 de novembro de 1990, com a assinatura da Declaração de Fiscalização Mútua. Trata-se de um marco no processo de integração atômica, uma vez que extrapola o campo normativo e procede a decisões concretas. Criou-se, por exemplo, o Sistema Comum de Contabilidade e Controle (SCCC) ${ }^{571}$, que previa o cumprimento das seguintes atividades: (1) intercâmbio das listas descritivas de todas as instalações nucleares e das declarações dos inventários dos materiais atômicos existentes em cada país; (2) realização de inspeções recíprocas nos sistemas centralizados dos registros; (3) apresentação dos sistemas de registros e relatórios do SCCC à AIEA. Além disso, a Declaração vislumbrou a entrada em vigor do Tratado de Tlatelolco, bem como a atualização de seus termos ${ }^{572}$, a partir do reconhecimento de que, "sem providências concretas e permanentes para assegurar transparência nos programas nucleares dos dois países, se incrementariam as restrições internacionais para acesso à tecnologia sensível" ${ }^{173}$.

Era muito clara a opção, dentro do marco conceitual de autonomia, daquilo que parecia o máximo a que ambos os países poderiam chegar sem sofrer obstruções sistemáticas por parte da potência hegemônica: o acesso tecnológico. Abandonava-se, por um lado, a busca por autonomia tecnológica que pautara o regime militar e havia sido sustentada pelo governo Sarney, não somente pela manutenção da pesquisa avançada no setor bélico, mas também da reserva de mercado da informática e da questão das patentes. Ao menos do lado brasileiro, buscava-se resistir, por outro lado, à adesão ao TNP - compreendido, nos meios diplomáticos e militares, como um instrumento desigual, de congelamento do poder mundial. Por isso mesmo, Brasil e Argentina buscavam uma espécie de "via híbrida" para o cumprimento das exigências da AIEA sem que tivessem que aderir ao Tratado. $\mathrm{O}$ primeiro passo deu-se pela harmonização do SCCC com registros e relatórios submetidos por outros países à Agência Internacional de Energia Atômica, de acordo com os acordos de salvaguardas vigentes. Adiante, os países deveriam firmar um acordo conjunto de

\footnotetext{
571 "O Sistema Comum de Contabilidade e Controle fora desenvolvido pelo Comitê Permanente BrasileiroArgentino sobre Política Nuclear e representava o cumprimento do mandato outorgado na Declaração sobre Política Nuclear, de 1985, no sentido de se criarem mecanismos para a manutenção da paz, da segurança e do desenvolvimento na América Latina. Por outro lado, sua implementação dificultaria o desvio das atividades nucleares para programas não submetidos a salvaguardas, como acontecera nos anos 80". Vargas, 1997, p. 56. 572 Oliveira, 1998.

${ }^{573}$ Vargas, 1997.
} 
salvaguardas com a AIEA, de modo a conferir legitimidade internacional ao mecanismo bilateral e a reafirmar, a um só tempo, os compromissos dos governos Collor e Menem com a não-proliferação ${ }^{574}$.

Esta via híbrida foi pavimentada em dois estágios. O primeiro deu-se a partir do Acordo Brasil-Argentina para o Uso Exclusivamente Pacífico da Energia Nuclear, celebrado às margens da I Cúpula Iberoamericana, em Guadalajara, em 18 de julho de 1991. O Acordo que, no fundo, representava a viabilização de jure da Declaração de Fiscalização Mútua estabeleceu a Agência Brasileiro-Argentina de Contabilidade e Controle de Materiais Nucleares (ABACC), com personalidade jurídica e sede no Rio de Janeiro. Um mês mais tarde, em 20 de agosto, firmou-se um Protocolo Adicional estabelecendo privilégios e imunidades aos funcionários e inspetores em missão ou serviços da ABACC.

Além do seu propósito declarado - afirmar o caráter exclusivamente pacífico de todo o material e de todas as instalações nucleares sob jurisdição e controle de cada um dos países o Acordo de Guadalajara envolvia outros compromissos significativos. Um deles era banir completamente as armas nucleares de seu território. Outro era reconhecer a inexistência de distinção técnica entre explosivos nucleares para fins pacíficos e os destinados a emprego militar $^{575}$. Tal dispositivo, nas palavras de Everton Vargas, "representou o abandono da posição que fora enunciada pelo Chanceler Guerreiro, em 1980, no sentido de que Brasil e Argentina se reservavam o direito a realizarem explosões pacíficas",576.

Por outro lado, o Acordo, em seu Artigo III, assegurou o uso de energia nuclear para "propulsão ou a operação de qualquer tipo de veículo, incluindo submarinos, uma vez que ambas são aplicações pacíficas da energia nuclear, ${ }^{\text {,577 }}$. Tendo como fundamento o Artigo V do Tratado de Tlatelolco, essa cláusula resguardava as pesquisas em curso pela Marinha brasileira, no Centro de Aramar, destinadas à construção de um submarino nuclear, além de servir para consolidar o apoio das Forças Armadas a uma política mais aberta em matéria

\footnotetext{
${ }^{574}$ Vargas, 1997, p. 53.

${ }^{575}$ Artigo I, parágrafo 3 do Acordo Entre a República Federativa do Brasil e a República Argentina para o Uso Exclusivamente Pacífico da Energia Nuclear: "Tendo em vista que não existe, atualmente, distinção técnica possível entre os dispositivos nucleares explosivos para fins pacíficos e os destinados a fins bélicos, as Partes se compromete, ademais, a proibir e a impedir em seus respectivos territórios, bem como a abster-se de realizar, fomentar ou autorizar, direta ou indiretamente, ou de participar de qualquer maneira no teste, uso, fabricação, produção ou aquisição, por qualquer meio, de qualquer dispositivo nuclear explosivo, enquanto persista a referida limitação técnica". Disponível em http://www.abacc.org.br/wpcontent/uploads/2011/07/acordo_bilateral_pt.pdf. Acesso em 25/09/2014.

${ }^{576}$ Vargas, 1997, p. 54.

577 Acordo Entre a República Federativa do Brasil e a República Argentina para o Uso Exclusivamente Pacífico da Energia Nuclear, Artigo III.
} 
nuclear ${ }^{578}$. Em síntese, nas palavras de Odete Maria de Oliveira, "o Acordo de 1991 concede às partes o direito inalienável ao desenvolvimento da pesquisa, produção e utilização da energia nuclear com fins pacíficos, preservando os segredos industriais, tecnológicos e comerciais de ambos os países" ${ }^{\text {579 }}$.

O segundo estágio envolveu a assinatura, em 13 de dezembro de 1991, na sede da AIEA em Viena, do Acordo Quadripartite entre Brasil, Argentina, a ABACC e a AIEA para aplicação de salvaguardas. Tratava-se de um sistema sui generis de salvaguardas multilaterais que foi capaz de reverter o quadro de mais de quatro décadas de política nuclear nos dois países, uma vez que colocaram sob vigilância todas as instalações, materiais nucleares e exportação de material atômico. Na coletiva concedida ao final da celebração do Acordo, Collor inscreveu a decisão no quadro maior das transformações internacionais, da substituição da bipolaridade ideológica por uma profunda clivagem Norte-Sul, geradora de novos riscos à paz e à estabilidade.

\begin{abstract}
"Infelizmente não existem ouvidos para escutar essa dramática realidade: os investimentos que foram feitos em armas nucleares, os investimentos que foram feitos em armamentos e que dariam para retirar desse quadro de miséria bilhões e bilhões de pessoas, três quartos da humanidade, assim não foram feitos (...). Brasil e Argentina deram hoje um passo histórico (...) no exemplo que daremos ao mundo, da necessidade da maior aceleração no processo de desarmamento".
\end{abstract}

Mais lacônico, Menem também saudou o acordo, na medida em que ele significava

\begin{abstract}
"um progresso no sentido de assegurar mais controle e um maior intercâmbio de tecnologia entre Brasil e Argentina (...). Precisamos nos adequar a todos os progressos do mundo. Não está havendo uma mudança de posição, mas um progresso, no sentido de buscar esse tipo de energia para a paz"580.
\end{abstract}

Dois outros pontos importantes foram abordados pelo presidente brasileiro na coletiva aos correspondentes internacionais. Um deles foi a recusa brasileira de assinar o TNP. Ao ser perguntado por que o Brasil não aderia ao tratado multilateral, ele ironizou: "porque nós não quisemos!". Naquele momento, de fato, o governo Collor estava conferindo prioridade aos arranjos bilaterais (embora com salvaguardas multilaterais que não comprometessem a

\footnotetext{
${ }^{578}$ Vargas, 1997, p. 54. A oposição militar a certas decisões internacionais do governo Collor já vinha das primeiras sinalizações, ainda no contexto da Guerra do Golfo, de que o Brasil abriria mão do seu programa nuclear. Ver, por exemplo, as declarações do Ministro da Marinha do governo Figueiredo, Maximiano da Fonseca. FSP, "Maximiano defende explosão de bomba atômica", 24 de setembro de 1990, p. A-5.

579 Oliveira, 1998, p. 16

${ }^{580}$ FSP, "Leia a íntegra da entrevista concedida pelo presidente da República em Viena", 14 de dezembro de 1991, p. 1-8.
} 
questão tecnológica) e o arranjo regional de Tlatelolco, que havia voltado à mesa de negociações entre Brasil e Argentina ${ }^{581}$. Adiante na entrevista, o presidente explicou-se:

\begin{abstract}
"O Tratado de Tlatelolco é um tratado de proscrição das armas nucleares; o TNP é um tratado de não-proliferação. Daí, há uma diferença grande de objetivos dos tratados. O TNP o Brasil não quis e não pode assinar porque havia a questão de suas conquistas tecnológicas, que foram agora mantidas com o tratado da AIEA".
\end{abstract}

O outro ponto se referia às resistências domésticas ao acordo com a AIEA. Everton Vargas lembra que seu processo de ratificação sofreu pressões contrárias por parte de setores envolvidos com atividades nucleares, que enxergavam o acordo como instrumento para sucatear a indústria nuclear brasileira através da importação de tecnologia ${ }^{582}$. Collor explicou que, como forma de garantir o encaminhamento do processo de salvaguardas nucleares com a Argentina, havia retirado o controle sobre a política nuclear ao nomear um civil, Pedro Paulo Leoni Ramos, para a Secretaria de Assuntos Estratégicos - responsável, entre outras questões sensíveis, pelo encaminhamento doméstico dos temas nucleares ${ }^{583}$. É possível ponderar que, diante das transformações estruturais da distribuição de poder no mundo, Collor e Menem (embora, como já se frisou, em compassos nem sempre alinhados) buscavam resistir às pressões internacionais e conservar sua autonomia, agora compartilhada no setor nuclear, e ao mesmo tempo oferecer às potências internacionais um compromisso de credibilidade. $\mathrm{Na}$ nova ordem mundial que se abria, países não engajados nos esforços de não-proliferação seriam tratados como párias mundiais e se veriam impedidos de acessar bens e serviços baseados nas tecnologias mais avançadas - inclusive em outros campos, como o aeroespacial ou o de informática. Tratava-se, em todo caso, de uma "avaliação realista" dos rumos do regime de não-proliferação nuclear, como conclui Everton Vargas:

\footnotetext{
"A transparência buscada através desses diferentes acordos refletem uma alteração profunda na visão do Brasil e da Argentina em relação a suas ações nacionais e suas relações com os países detentores de tecnologias avançadas. Verificou-se uma revisão da estratégia de inserção internacional de cada um dos países, com uma disposição para se tornar parte do regime internacional de não-proliferação e seu consequente credenciamento como parceiros confiáveis, sobretudo no que se refere à utilização de tecnologias de duplo uso"
}

\title{
5.4. A consolidação da autonomia: Rose Garden Agreement
}

\footnotetext{
${ }^{581}$ Oliveira, 1998, p. 17.

${ }^{582}$ Vargas, 1997, p. 55.

${ }^{583}$ FSP, “Collor e Menem assinam acordo nuclear", 14 de dezembro de 1991, p. 1-8.

${ }^{584}$ Vargas, 1997, p. 56.
} 
O campo da integração regional é aquele que, ao longo de todo o período do governo Collor, testemunhou os avanços mais expressivos. No capítulo anterior, tratou-se do processo que culminou na assinatura do Tratado de Assunção, em 26 de março de 1991. Nessa terceira fase da política externa "colorida", o aprofundamento do Mercosul revela-se como um mecanismo de promoção da inserção competitiva do Brasil e de seus vizinhos. Ao contrário do que sustenta Vizentini, para quem a intenção da equipe de Zélia Cardoso de Mello havia sido transformar "uma integração de ambições desenvolvimentistas (...) num instrumento de política econômica neoliberal" ${ }^{155}$, acreditamos que o estabelecimento - e a continuidade - do Mercosul foi, no limite, uma maneira de reduzir as vulnerabilidades econômicas de seus membros e, ao mesmo tempo, resistir aos riscos iminentes de uma tentativa de integração hemisférica que já se materializara na Iniciativa para as Américas. A passagem de Seintefus é ilustrativa nesse sentido:

\begin{abstract}
"Sem desconsiderar a importância dos aspectos estratégicos e da necessidade de reunir forças para melhor se inserir no sistema econômico internacional, caracterizado pela progressiva formação de blocos econômicos, o objetivo fundamental do Mercosul é a busca do crescimento econômico. Constituindo reiteração dos princípios norteadores dos protocolos argentino-brasileiros resumidos na ideia de crescer juntos, os quatro países, cientes que o Norte desenvolvido engolfado por seus problemas não oferece condições de cooperação semelhantes àquelas dos anos 50 e 60, pretendem aumentar sua competitividade internacional com incremento da produtividade e investimentos tecnológicos e modernização do processo produtivo. Para tanto, é necessário diminuir a intervenção estatal através de uma política de privatização, canalizar investimentos para as áreas mais competitivas, liberalizar a economia através da diminuição do controle de preços e das tarifas de proteção, colocando as economias nacionais paulatinamente em confronto na competição internacional" ${ }^{1586}$.
\end{abstract}

Havia, contudo, dois importantes entraves de ordem sistêmica. O primeiro deles dizia respeito às continuas pressões norte-americanas pelo fim das políticas protecionistas dos membros do bloco e de suas salvaguardas de propriedade intelectual. A mensagem do vicepresidente Dan Quayle era clara: “Qualquer arranjo regional que se move em uma direção protecionista simplesmente se auto-derrotará (...). Investidores sairão na defensiva se não se convencerem sobre a proteção de suas patentes e seus direitos intelectuais sobre produtos" ${ }^{\text {"587. }}$. $\mathrm{Na}$ prática, significava que a disposição dos Estados Unidos em aprofundar as relações comerciais com o Mercosul, no marco da Iniciativa para as Américas, dependeria da

\footnotetext{
${ }^{585}$ Vizentini, Paulo Fagundes. "O Brasil, o Mercosul e a integração da América do Sul”. Revista de Estudos e Pesquisas sobre as Américas, vol. 1, no. 1, 2007, p. 2.

${ }^{586}$ Seitenfus, Ricardo. "Considerações sobre o Mercosul”. Estudos Avançados, vol. 6, no. 16, 1992.

${ }^{587}$ Citado em Dandeker, Rebecca D. "The Rose Garden Agreement: is Mercosur the next step to a hemispheric free trade zone?". Law and Policy in International Business, vol. 24, no. 1, 1992.
} 
resolução anterior de contenciosos individuais entre os EUA e cada um dos membros do bloco. A superação dos entraves bilaterais com o Brasil foi enfatizada por Bush no encontro que teve com Collor em Washington, no dia 18 de junho de 1991.

A conversa particular entre Collor e Bush mostra uma renovada disposição em fazer concessões. Entendia-se essa postura como pré-condição para assegurar a viabilidade do projeto político-econômico do Mercosul. Se o encaminhamento da questão das patentes e da informática minava, por um lado, os resquícios do protecionismo nacional-desenvolvimentista que alguns, no Brasil, ainda encaravam como a garantia de autonomia nacional frente às influências da potência hegemônica, ele abria espaço, por outro lado, para o fortalecimento da iniciativa quadripartite na qual o governo brasileiro parecia depositar parte importante de suas fichas.

Havia, contudo, um segundo entrave que se revelou ao longo do ano de 1991. Pesavam sobre as negociações do Mercosul, em primeiro lugar, as incertezas econômicas e políticas nos dois países, especialmente no Brasil. Além disso, consideráveis divergências intra-bloco, sobretudo entre Brasil e Argentina, dificultavam o encaminhamento da construção de um consenso externo que servisse de base para negociações com parceiros como os Estados Unidos. A despeito do formato quadrilateral que o processo negociador havia assumido desde o Tratado de Assunção, o eixo brasileiro-argentino mantinha-se como cerne da dinâmica e da negociação dentro do Mercosul. E exatamente ali residiam as questões mais complexas. De acordo com Alcides Vaz, o expressivo aumento comercial que se verificou entre Brasil e Argentina exercia um impacto ambíguo no contexto das negociações do bloco. De um lado, evidenciava o comprometimento político dos governos e atores domésticos para com o projeto de integração, tendo em vista a velocidade com que caminhava o processo de integração. De outro, a acumulação de déficits comerciais pela Argentina levou à introdução gradual de aspectos conflitivos entre os dois principais sócios do Mercosul, colocando em xeque os esforços de liberalização comercial - que era a espinha dorsal de toda a empreitada. Embora a liberalização avançasse como pactuado,

\footnotetext{
"seus efeitos sobre setores menos competitivos, mas com capacidade de pressão política, induziam os governos, principais protagonistas do processo negociador, a recorrerem a medidas e instrumentos que denotavam um padrão de comércio administrado, o que terminava por macular e fragilizar o regime de livre comércio que pretendiam instaurar, ${ }^{, 58}$.
}

\subsubsection{Mantendo a frente unida}

${ }^{588}$ Vaz, 2002, p. 188 
A despeito dos constrangimentos sistêmicos, havia uma diretriz muito clara de não desacelerar o processo de integração do Cone Sul, uma vez que ela representava uma salvaguarda às economias locais e, ao menos da perspectiva da política externa brasileira, uma garantia de autonomia. Foi com essa mentalidade que os países-membros do Mercosul negociaram com os Estados Unidos um acordo sobre comércio e investimentos - o chamado 4 + 1 ou Rose Garden Agreement (Acordo do Jardim das Rosas). Uma aproximação entre os EUA e os quatro países-membros do Mercosul já vinha sendo costurada desde o lançamento da Iniciativa para as Américas, um ano antes, quando ainda não se falava no Mercosul como instituição. Desde aquela época, sabia a diplomacia brasileira que, mesmo com todo o potencial de atrativos que continha o Plano Bush, era fundamental evitar uma reação desordenada dos países envolvidos no processo de integração sub-regional. Destarte, poucos dias após o discurso de lançamento da Iniciativa para as Américas, os presidentes Collor e Menem decidiram que seus respectivos países dariam uma resposta unificada ao Plano Bush. Reuniões subsequentes, ocorridas entre agosto e setembro de 1990, incorporaram o Chile (que se retirou das negociações posteriormente, optando por seguir um caminho próprio de negociação direta com os EUA), o Uruguai e, mais tarde, o Paraguai ${ }^{589}$.

Essa delegação quadripartite (Argentina, Brasil, Paraguai e Uruguai) reuniu-se com autoridades norte-americanas em Washington em setembro de 1990. O encontro dividiu-se em duas partes: a primeira, realizada no Departamento do Tesouro, serviu para explicar aos diplomatas sul-americanos sobre o alcance, bem como as limitações, do Plano Bush em suas vertentes sobre dívida e investimentos. "Não se iludam", disse um funcionário norteamericano, "isto não é um Plano Marshall”. Na outra parte da reunião, realizada no Departamento de Estado, o governo norte-americano ofereceu aos seus interlocutores uma proposta de acordo em cima do texto-modelo que havia servido de base para a negociação com outros países da região, tocando marginalmente em questões caras à delegação do Cone Sul, como investimentos e tecnologia. Segundo o relato de Celso Amorim e Renata Pimentel,

\footnotetext{
"Ficou evidenciado que, por um lado, os quatro países sul-americanos não iriam simplesmente (...) assinar um 'contrato de adesão' (...) e que, por outro lado, os EUA não estavam preparados para discutir um acordo que se afastasse de sua proposta inicial, ainda que tendo como inspiração os próprios princípios da Iniciativa para as Américas" ${ }^{, 590}$.
}

\footnotetext{
${ }^{589}$ Amorim, Celso e Pimentel, Renata. "Iniciativa para as Américas 'O Acordo do Jardim das Rosas"”. In: Albuquerque, José Augusto Guilhon (org.). Sessenta Anos de Política Externa Brasileira (1930-1990). Volume II: Diplomacia para o desenvolvimento. São Paulo: NUPRI, 1996.

590 Amorim e Pimentel, 1996, p. 114.
} 
As negociações nos moldes Cone Sul + Estados Unidos prosseguiram até a virada do ano, encontrando diversas resistências por parte do governo Bush, que se recusava a tratar coletivamente das questões da dívida e negava-se a sistematizar a discussão sobre tecnologia e finanças ${ }^{591}$. No início de 1991, em Punta del Este, os representantes diplomáticos de Brasil, Argentina e Uruguai concordaram que seria inútil insistir na ampliação dos objetivos do acordo-quadro - que se manteve limitado a aspectos básicos sobre comércio e investimentos centrando-se, a partir de então, na melhoria da posição conjunta em matéria comercial. A celebração do Tratado de Assunção, em março, não interrompeu as negociações coletivas com os norte-americanos. O que mais surpreendia o governo Bush é que, ao contrário de outros temas em que ele mostrou-se capaz de negociar individualmente com seus contrapartes latinoamericanos, os governos do Mercosul mantiveram-se rigorosamente unidos até o fim do processo, que culminou no Rose Garden Agreement, em 19 de junho de 1991.

Ao fim e ao cabo, qual o significado do acordo $4+1$, e como ele se insere no marco mais amplo das estratégias de inserção internacional do Brasil? Em primeiro lugar, deve-se dizer que ele é um desdobramento natural da nova relação dos Estados Unidos com a América Latina, consubstanciada no Plano Bush. Sendo assim, não se pode negligenciar a importância simbólica e prática que o acordo tem para os EUA. Simbólica, uma vez que o Rose Garden sinalizava, da parte dos países do Mercosul, a disposição de dar seguimento - embora o timing fosse uma questão a ser discutida - ao projeto de integração comercial hemisférica. Prática porque, ainda que as metas originais não fossem ambiciosas, dadas as próprias dificuldades da negociação, o acordo ao menos permitiria ao governo Bush monitorar, com mais proximidade, o processo de integração sub-regional - o que lhe interessava diretamente ${ }^{592}$.

Em segundo lugar, o Acordo do Jardim das Rosas representava um reconhecimento explícito da relevância política do Mercosul, ao assumir a legitimidade do modelo $4+1$, além de avançar os interesses dos quatro países sul-americanos a respeito do comércio agrícola agora subscritos pelos Estados Unidos - no âmbito do GATT. A avaliação do então chanceler uruguaio, Hector Gros Espiell, vai ao encontro dessa interpretação:

\footnotetext{
591 "Essas resistências se manifestaram de forma até surpreendente na recusa, em momento posterior da negociação, a uma simples referência entre os consideranda do acordo, ao 'conceptual framework of the Initiative for the Americas', com a qual, de forma algo sutil, os países sul-americanos buscavam relembrar a ideia do vínculo entre as três vertentes da Iniciativa”. Amorim e Pimentel, 1996, p. 114.

592 Amorim e Pimentel, 1996, p. 117.
} 
“O Quatro mais Um constitui o reconhecimento pelos Estados Unidos de que o Mercosul é o plano de integração sub-regional mais sério e profundo jamais montado até agora - algo semelhante, pode-se afirmar, à representação feita em abril pelos quatro ministros das Relações Exteriores do Mercosul na Comissão da Comunidade Europeia (...).

De forma específica, os signatários concordam em que é necessária uma reforma profunda do comércio agrícola, o que inclui se opor aos subsídios nas exportações entre as partes signatárias, assim como em relação a terceiros (...). É assim que vamos encarar ações conjuntas na Rodada Uruguai do Acordo Geral sobre Tarifas e Comércio (Gatt) para chegar a um acordo final ambicioso, amplo e equilibrado"593

Finalmente, o Acordo-Quadro entre os países do Mercosul e os EUA demonstrava a capacidade de articulação e de resistência dos sul-americanos, liderados pela diplomacia brasileira, a mais interessada em manter o grupo unido frente às demandas do governo Bush $^{594}$. De acordo com Celso Amorim, um dos negociadores brasileiros:

\begin{abstract}
"Uma peculiaridade das negociações que levaram a esse acordo é que foi a primeira vez que houve o exercício de uma coordenação efetiva, o que causou muita surpresa aos Estados Unidos. Quando falamos em "coordenação" não é uma figura de retórica, foi algo real. Isso causou muita surpresa aos Estados Unidos. Primeiro, eles relutaram muito em discutir com os quatro países. Eles achavam que deveriam discutir com cada país separadamente, ou no conjunto das Américas, digamos assim. Finalmente, aceitaram. Mas, mesmo depois que aceitaram, eles achavam que era uma reunião de cinco países e nós tivemos que explicar para eles que não era uma reunião de cinco países, mas sim, de $4+1,595$
\end{abstract}

A capacidade da diplomacia brasileira em manter a delegação do Mercosul unida era importante para evitar o efeito sistêmico regional de que se falou anteriormente. Funcionando como um centro de gravidade alternativo (e, em certo sentido, mais atraente), os Estados Unidos poderiam colocar em risco os interesses regionais brasileiros, bem como sua capacidade de manutenção da autonomia, para a qual a unidade do Cone Sul era imprescindível. Compreendiam os operadores da política externa, ademais, que as negociações do NAFTA - que caminhavam em ritmo acelerado - não poderiam causar ansiedade nos quadro países do Mercosul, empurrando-os para concessões maiores diante dos Estados Unidos. Ao contrário, a consolidação da integração sub-regional tornava-se ainda mais fundamental, de modo a capacitar os quatro países a obter, no médio prazo, vitórias importantes no plano hemisférico, mesmo que se considerasse inexorável o estabelecimento de uma zona de livre comércio.

\footnotetext{
${ }^{593}$ Espiell, Hector Gros. "Quatro mais um igual a dois”, OESP, 19 de junho de 1991, p. 2.

${ }^{594}$ Para avaliações sobre o interesse brasileiro na manutenção do bloco, ver Fernandez, Wilson. Mercosur: economia, politica y estrategia en la integracion. Montevideo: FCU, 1992; Menendez, Cristina e Kerz, Mercedes. Autocracia y Democracia: Brasil - un camino al Mercosur. Buenos Aires: Editorial de Belgrano, 1993.

${ }^{595}$ Amorim, Celso. “A integração sul-americana”. Diplomacia, Estratégia \& Política, no. 10, out/dez 2009, p. 9.
} 


\section{5. "Diplomacia com as próprias mãos": o périplo africano}

Em setembro de 1991, o presidente Fernando Collor de Mello embarcou em uma viagem à África austral, na qual percorreria quatro países em seis dias. Antes de tudo, a ausência do país carregava uma simbologia externa. Ajudava a dirimir, por um lado, os rótulos primeiro-mundistas que haviam sido utilizados em abundância no início do governo tanto por ele próprio quanto pelos críticos - e que sugeriam um afastamento dos países africanos. De acordo com nota oficial do Planalto, a viagem "servirá para demonstrar a prioridade que o governo brasileiro confere às relações com o continente africano",596. Vinte anos antes, havia sido o chanceler Mário Gibson Barboza a inaugurar um profícuo período de universalismo das relações exteriores brasileiras ao realizar viagem semelhante a nove países da África negra ${ }^{597 .}$

Por outro lado, Collor demonstrava interesse em reaproximar-se de um conjunto de nações com os quais o comércio havia perdido dinamismo ao longo da década de 1980. Ainda que de maneira seletiva, como nos lembra Cláudio Ribeiro, havia um desejo de aprofundar laços de troca que se conectassem às necessidades imediatas do Brasil: importação de petróleo e exportação de produtos manufaturados e serviços (principalmente de engenharia) ${ }^{598}$. O momento era propício: segundo David Lerer, “[a] implosão do poder soviético foi o golpe final na África Negra. Seu peso político despencou para zero. A ajuda econômica secou de

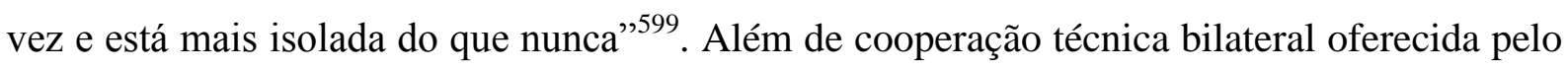
governo, empresas como Odebrecht - cujo presidente, Norberto Odebrecht, acompanhava a comitiva presidencial - e Vale do Rio Doce, além de outros segmentos (como em comunicação e produção de TV ${ }^{600}$, vislumbravam oportunidades econômicas.

Não se pode, ademais, deixar de relacionar a viagem de Collor à visita de cinco dias realizada pelo líder do Congresso Nacional Africano (CNA), Nelson Mandela, que percorreu três estados (RJ, SP e ES) e o Distrito Federal, no início de agosto. O momento internacional,

\footnotetext{
${ }^{596}$ FSP, "Viagem possui caráter politico", 8 de setembro de 1991, p. 1-4.

${ }^{597}$ Ver Lessa, Antônio Carlos. "A diplomacia universalista do Brasil: a construção do sistema contemporâneo de relações bilaterais". Revista Brasileira de Política Internacional, vol. 41, no. 2, 1998; Penna Filho, Pio e Lessa, Antônio Carlos. "O Itamaraty e a África: as origens da política africana no Brasil”. Estudos Históricos, vol. 39, no. 1, 2007.

${ }^{598}$ Ver o depoimento do então Secretário de Assuntos Estratégicos, Pedro Paulo Leoni Ramos em Ribeiro, Cláudio Oliveira. "As relações Brasil-África entre os governos Collor e Itamar Franco". Revista Brasileira de Ciência Política, no. 1, 2009, p. 311.

${ }^{599}$ Lerer, David. "Perestroika na África". Folha de São Paulo, 12 de setembro de 1991, p. 1-3.

${ }^{600}$ FSP, "Eleição angolana terá agência brasileira", 8 de setembro de 1991, p. 1-4.
} 
no auge da luta contra o apartheid sul-africano, era propício para que Collor pudesse capitalizar seu novo discurso "africanista”. Em seu encontro com Mandela, o presidente brasileiro ouviu denúncias de que algumas superpotências suspenderam sanções econômicas contra a África do Sul "antes de o governo conceder aos negros o direito de votar" e reiterou seu compromisso de que o Brasil manteria o boicote comercial ao país enquanto o regime de segregação não fosse totalmente eliminado ${ }^{601}$.

Em editorial, $O$ Globo tece considerações elogiosas sobre a viagem, considerando-a parte de uma diplomacia "pragmática", desvinculada de rótulos: "Nos quatro países do roteiro do presidente Collor há campo de penetração para a empresa privada brasileira e para iniciativa de cooperação política (...). É conveniente e oportuna a aproximação com países africanos"602. A única ressalva feita pelo jornal dizia respeito ao timing da viagem. Deve-se sublinhar que o "périplo africano" de Collor também possuía um sentido político para dentro: o Brasil estava em crise e o presidente talvez já não conseguisse reunir mais forças para lidar com ela ${ }^{603}$. À aguda perturbação política que se desenrolava contra o pano de fundo das negociações do "Emendão", somavam-se episódios pontuais envolvendo a família da primeira-dama em seu estado-natal ${ }^{604}$ e denúncias de corrupção que caíam sobre membros da chamada "República das Alagoas", notadamente o empresário Paulo César Farias ${ }^{605}$. Sintomático desse aspecto é, por exemplo, a oferta brasileira a Angola, via protocolo bilateral de intenções, de transferência de know-how dos Centros Integrados de Atenção à Criança (Ciacs) - uma das bandeiras do governo Collor no campo da educação infantil - quando o projeto, no Brasil, perdia credibilidade a olhos vistos ${ }^{606}$. O diagnóstico da viagem feito pelo deputado Delfim Netto (PDS-SP) resumia bem o problema: "Collor, que tentou voltar ao presidencialismo imperial do século 18 ao propor o emendão, está indo agora a Moçambique conhecer o futuro do Brasil" ${ }^{607}$. De maneira mais elaborada, Roberto Campos também rechaça a decisão da viagem:

\footnotetext{
${ }^{601}$ FSP, "Mandela exige direito de voto para negros", 6 de agosto de 1991, p. 1-6.

${ }^{602}$ O Globo, "Diplomacia pragmática", 10 de setembro de 1991, p. 6.

${ }^{603}$ Uma famosa frase do senador Fernando Henrique Cardoso, repetida sempre que o presidente José Sarney deixava o país, foi recordada no Congresso em meio à turnê de Collor, com o paralelo inevitável: "A crise está viajando". OESP, "Coluna do Estadão", 13 de setembro de 1991, p. 3.

604 Após a divulgação de denúncias de malversação de fundos em Canapi (AL), envolvendo a gestão da primeiradama na Legião Brasileira de Assistência (LBA), o irmão de Rosane Collor foi protagonista de um tiroteio em frente à prefeitura da cidade, cujo alvo era o prefeito, suposto culpado pelo vazamento das acusações. Ver FSP, "Brasil, Alagoas", 10 de setembro de 1991, p. 1-2.

${ }^{605}$ Dimenstein, Gilberto. "Dança com lobos". Folha de São Paulo, 10 de setembro de 1991, p. 1-2.

${ }^{606}$ FSP, "Miragem educacional", 10 de setembro de 1991, p. 1-2; FSP, "Angola assina acordo de Ciacs", 11 de setembro de 1991, p. 1-5.

${ }^{607}$ FSP, "Painel", 8 de setembro de 1991, p. 1-4.
} 
“O planejamento de um périplo presidencial à África, em meio a uma grave crise de governabilidade, revela no Itamaraty falta de senso de prioridades ou uma recaída no terceiro-mundismo. O terceiro-mundismo, como se sabe, é uma espécie de sindicato dos pobres. Sob essa ótica sindical, a relação entre países ricos e pobres é uma relação adversária: um jogo de soma zero (...). O ressentimento é esporte mais fácil do que a autocrítica",608.

Ao fim e ao cabo, se a retórica de aproximação com o Terceiro Mundo havia ganhado corpo em Guadalajara, na viagem de Collor ela atingia seu ápice. Na superfície dos pragmáticos acordos comerciais como aqueles vislumbrados com Angola, palavras de contestação à ordem vigente reapareciam nos discursos presidenciais:

“Ao bipolarismo Leste-Oeste não pode suceder a cristalização de uma etapa histórica em que se aprofunde o fosso entre os países do Norte e os países do Sul, em que, no âmbito de muitas nações, convivam disparidades de riqueza que neguem os objetivos, hoje universais, de afirmação da justiça social" ${ }^{609}$.

Com uma comitiva enxuta, na qual Rezek era o único ministro de Estado, as visitas de Collor aos demais países foram rápidas e também simbólicas ${ }^{610}$. O presidente encontrou-se com seu contraparte do Zimbábue, Robert Mugabe, a quem propôs a exportação de tecnologia de produção de álcool combustível, dada a carência de petróleo do país africano. Em Moçambique, Collor e o mandatário local, Joaquim Chissano, clamaram por assistência internacional aos países pobres ${ }^{611}$.

Finalmente, na Namíbia, país recém-independente ${ }^{612}$, o presidente brasileiro propôs o aprofundamento das relações em três áreas: (1) desenvolvimento e cooperação no aproveitamento de recursos hídricos para produção de energia e agricultura; (2) atividades de extensão rural e formação de recursos humanos, em arranjos bilaterais ou triangulares; (3) coordenação do desenvolvimento dos países da África Austral, com vistas a manter o Atlântico Sul como zona de paz e cooperação. "De um lado e de outro do Atlântico, é tempo de unirmos forças, agora que a paz retorna à África Austral, para acelerar o desenvolvimento econômico e social de nossos povos", afirmou Collor ao presidente namibiano, Sam Nujoma ${ }^{613}$.

\footnotetext{
${ }^{608}$ Campos, Roberto. "De volta à gafieira...". O Globo, 15 de setembro de 1991, p. 3.

${ }^{609}$ FSP, "Collor encerra hoje sua visita à África", 13 de setembro de 1991, p. 1-5.

${ }^{610}$ A cobertura da imprensa estava mais preocupada com um entrevero conjugal entre Collor e Rosane do que com a viagem em si. No dia 12 de setembro, por exemplo, a única nota da Folha de São Paulo sobre a visita ao Zimbábue tinha o seguinte título: "Ainda sem aliança, Collor beija Rosane em público no Zimbábue”, p. 1-11.

${ }^{611}$ OESP, "Brasil quer exportar álcool para África", 12 de setembro de 1991, p. 7.

${ }^{612}$ A Namíbia tornou-se independente em 21 de março de 1990 do controle de facto da África do Sul - ainda sob o regime do apartheid - sobre o território da África do Sudeste.

${ }^{613}$ OESP, "Collor quer aumentar comércio com a África", 14 de setembro de 1991, p. 27.
} 
Pouco antes de embarcar de volta a Brasília, o governante brasileiro concedeu entrevista coletiva, em que se discutiu a crise econômica e fez-se um balanço da viagem à África. A fala aos jornalistas retomava um hábito de governantes brasileiros - escolher um país estrangeiro para fazer declarações políticas de efeito. Foi assim com Geisel, cuja primeira coletiva havia sido feita durante uma viagem à França, em 1976, e com Figueiredo, em 1984, que disse ser "pessoalmente" favorável às eleições presidenciais diretas no Brasil, numa viagem à Nigéria ${ }^{614}$. Falou de suas expectativas a respeito das relações com a África:

\begin{abstract}
"O Brasil tem uma visão muito positiva do futuro do continente africano, e particularmente desta parte da África, a África Austral. A partir do momento em que nós tenhamos equacionada, de uma maneira mais rápida, a questão do Apartheid na África do Sul, nós teremos o grande sinal da prosperidade econômica dos países desta região. Por isso a viagem que hoje termino a esta parte do continente africano pode ser vista como um estreitamento não somente dos nossos laços históricos e culturais, com os países de língua portuguesa, e o adensamento de nossas relações econômicas, com esses dois países também, mas em relação àqueles de língua inglesa. A possibilidade de abertura de novos canais de intercâmbio comercial, tecnológico e cultural’,615.
\end{abstract}

Collor também aproveitou a oportunidade para dar um recado à oposição, que exigia a extinção da "República de Alagoas", cujos políticos (próximos ao presidente) acumulavam acusações de corrupção: "não se faz imposição num regime democrático, a quem quer que seja, nem o presidente impõe nada, nem muito menos aceita imposição de quem quer que seja”. De volta ao Brasil, a situação não era das mais favoráveis. Enquanto o presidente concluía sua viagem, os governadores de São Paulo, Luiz Antônio Fleury Filho (PMDB), e de Minas Gerais, Hélio Garcia (PRS), reuniram-se para discutir as possibilidades de entendimento nacional. O grau de paralisia das relações entre Executivo e Legislativo em torno do "emendão", bem como o desgaste igualmente acumulado com os governadores de estado, trazia de volta o fantasma do golpe. O clima era de pessimismo, como lembrou o governador mineiro: "Não cabe a nós dizer que é o [golpe] de 1961 ou o de 1964, mas não podemos repetir o que vivemos no passado" ${ }^{\circ 616}$.

Como movimento final de seu breve interesse pela África, o governo brasileiro lançou nota de congratulação ao governo da África do Sul - "que reafirma o seu compromisso de desmantelar o apartheid" - e ao Congresso Nacional Africano e seu líder, Nelson Mandela "cuja luta pela igualdade de direitos entre todos os sul-africanos é fundamental para a evolução do quadro interno daquele país, tanto quanto o apoio oferecido pelos diferentes

\footnotetext{
${ }^{614}$ OESP, "Uma tática conhecida", 14 de setembro de 1991, p. 4.

${ }^{615}$ OESP, "O presidente faz e não aceita imposição". 14 de setembro de 1991, p. 4.

${ }^{616}$ OESP, "Garcia reúne-se com Fleury e lembra golpe", 11 de setembro de 1991, p. 4.
} 


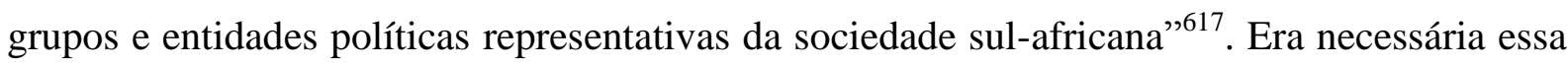
manifestação para demonstrar, a um só tempo, o compromisso brasileiro com o universalismo das relações diplomáticas - principalmente no tocante a um país em distensão política, como a África do Sul - e a defesa de Mandela e seu partido, que poderia render ao Brasil (e, naturalmente, a Collor) certo capital político em tempos de renovadas desconfianças internacionais com relação aos rumos da política brasileira.

\title{
5.6. A reformulação conceitual: o discurso nas Nações Unidas
}

Aparentemente ignorando os problemas domésticos, menos de dez dias após o retorno do périplo africano Collor de Mello embarcava novamente para o exterior, dessa vez para os Estados Unidos, com o objetivo de discursar na abertura da Assembleia-Geral da ONU. O Emendão, texto básico do entendimento nacional, estava em sua $14^{\mathrm{a}}$ versão escrita e a situação política chegava a um ponto de esgarçamento do qual talvez não houvesse retorno. A decisão pela nova ausência gerou críticas, como a que se leu na seção editorial do Estadão:

\begin{abstract}
"A situação é urgente demais para que o chefe de Estado se dê ao luxo de discursar na ONU, conversar meia hora com o presidente dos Estados Unidos, reclamar investimentos na Comunidade Econômica Europeia, examinar as virtudes de um parlamentarismo que se deseja transformar em presidencialismo na Itália e cuidar da integração do Cone Sul no Uruguai e no Chile. Porque, afinal, para que tudo isso produza algum efeito, para que o presidente Bush dê a ajuda prometida ao Brasil de 1990 e os capitais europeus acorram ao País e não prefiram, por pirraça, aportar na Venezuela, no México e no Chile, é preciso que a Nação esteja tranquila, que no Congresso não se fale abertamente em impeachment do chefe de Estado como solução da crise, que a economia entre nos trilhos e não esteja à mercê da vontade de pessoas que não se entendem. A política institucional precisa ser levada a sério (...).

Por mais que o chanceler Rezek explique os motivos profundos que levam o chefe de Estado a distanciar-se de Brasília, o presidente Collor de Mello deveria, de fato, aqui permanecer e jogar o prestígio de que ainda goza para encontrar uma $15^{\mathrm{a}}$ ou $20^{\mathrm{a}}$ versão que fosse do Emendão para impedir a catástrofe, que o senador Passarinho (...) não hesita em dar como certa, se não houver acordo",618
\end{abstract}

Antes de abrir os trabalhos da XLVI Assembleia Geral, Collor teve uma reunião de trabalho com Bush no próprio Waldorf Astoria. O tom da conversa foi muito mais formal e seco do que nas oportunidades anteriores. O presidente brasileiro, em linha com o que já vinha dizendo desde Guadalajara, abriu a reunião exortando Bush a abraçar a bandeira da causa social. "Gostaria de vê-lo liderar de um modo tal que os países do mundo virem-se para

\footnotetext{
${ }^{617}$ RPEB “Acordo de paz na África do Sul”, Nota à imprensa, 19 de setembro de 1991, p. 243.

${ }^{618}$ OESP, “O presidente viaja!", 13 de setembro de 1991, p. 3.
} 
os problemas mundiais de desenvolvimento. Preocupa-me que três-quartos das pessoas do mundo vivam em necessidade, pobreza e privação. Precisamos mudar isso. Trata-se de uma situação muito perigosa". O norte-americano foi direto: "estou convencido de que a negociação satisfatória de um acordo comercial é o passo mais importante que trará progresso econômico aos países em desenvolvimento. Também acredito que uma rodada bem-sucedida do GATT ajudará bastante" ${ }^{619}$. Àquela altura, havia pouco, no âmbito do GATT, que o Brasil não tivesse cedido às pressões norte-americanas.

Além do tema da pobreza, Collor tocou nas questões da dívida externa, das salvaguardas nucleares e do meio ambiente. Nas três, o Brasil assumiu a posição de demandante: sugeriu que os EUA, na figura de David Mulford, se sentasse com os bancos para pedir-lhes mais flexibilidade na contra-proposta oferecida ao Brasil; solicitou ajuda para que a diplomacia americana também contribuísse para a flexibilização das restrições da AIEA nas negociações do Acordo Quadripartite; finalmente, na questão ambiental, Collor sondou Bush a respeito da possibilidade de que o norte-americano convencesse seus parceiros do G-7 a liberar um fundo de US\$ 1,2 bilhão no contexto de um programa de preservação da Amazônia.

Em contrapartida, o Brasil ofereceu total apoio à questão do sionismo e da Resolução 3379 (sionismo = racismo), cuja revogação na Assembleia Geral já estava sendo cogitada pelos norte-americanos. “O que quer que façamos?”, perguntou Collor. "Gostaríamos que copatrocinassem uma simples resolução de repúdio", disse o presidente dos EUA ${ }^{620}$. Ainda se recuperando das perdas econômicas causadas pela Guerra do Golfo, o governo israelense precisava de respaldo multilateral para solicitar empréstimos no FMI $^{621}$, para o qual a reversão da resolução antissionista seria fundamental, de modo a criar um ambiente mais favorável. Contudo, era interessante para os Estados Unidos que outros países liderassem a iniciativa, de modo a legitimá-la. Em 16 de dezembro de 1991, o Brasil emprestou seu nome à longa lista de patrocinadores (90 no total) que, num texto curto - "A Assembleia Geral decide revogar a determinação contida em sua Resolução 3379 (XXX) de 10 de novembro de 1975" - encerrou a querela de uma década e meia contra Israel ${ }^{622}$. Da parte brasileira, criaram-se condições para superar as desconfianças israelenses contra as intenções da política exterior do

\footnotetext{
${ }^{619}$ The White House. "Memorandum of conversation".

${ }^{620}$ Idem, p. 4.

${ }^{621}$ A liberação dos empréstimos de fato ocorreu algum tempo depois, em março de 1992. Ver Los Angeles Times, "Israel: \$243-million IMF loan approved", 28 de março de 1992. Disponível em http://articles.latimes.com/1992-03-28/news/mn-4174_1 imf-loan-approved. Acesso em 01/09/2014.

${ }^{622}$ Ver Resolução 46/86, "Eliminação do racismo e da discriminação racial". United Nations. Yearbook of the United Nations (1992). New York: Department of Public Information, 1992, p. 537.
} 
Brasil no Oriente Médio, nascidas nos tempos do pragmatismo responsável e revividas no contexto da crise do Golfo.

Ao contrário das manifestações dos meses anteriores, algumas das quais até dotadas de certa estridência, o discurso nas Nações Unidas manteve um tom compatível com a necessidade de não colocar em jogo o que restava da postura cooperativa dos EUA. Na avaliação de Seixas Corrêa, "o tom esperançoso do discurso do ano anterior cederia lugar a uma linguagem mais cautelosa, em que, aos elementos positivos surgidos com a evolução da conjuntura internacional, viriam a somar-se alguns aspectos de crescente preocupação"623. As preocupações relacionavam-se a três desafios, identificados por Collor no discurso como o “desafio econômico do desenvolvimento", o "desafio político para a paz" e o "desafio ético de assegurar uma vida digna a todos" - que deveriam ser enfrentados conjuntamente e de maneira democrática. Do ponto de vista prático, o Brasil não ofereceu nenhuma proposta concreta ou linha de ação, limitando-se a pontuar episódios que se encaixavam nos desafios esquematicamente propostos pelo presidente.

Tratou-se, no limite, de um discurso eminentemente conceitual, "em que se retomam os temas tradicionais da diplomacia brasileira: desenvolvimento e paz"624. Temas que foram inseridos no marco daquilo que Collor batizou de "social-liberalismo", noção formulada por Merquior nos anos anteriores e compartilhada com o presidente, ainda no processo de formação do governo. Percebe-se que, depois de ir da modernização incondicional ao terceiro-mundismo radical, o Collor buscava uma síntese - que fosse capaz de exprimir os anseios internacionais do Brasil, por um lado, e remodelar sua imagem perante o espectador externo, por outro:

\footnotetext{
"O ideário liberal venceu, e devemos lutar para que se imponha de forma coerente, ampla e, sobretudo, inovadora. Essa é uma observação que faço da perspectiva de um país que optou por uma plataforma liberal com um claro sentido social - o social-liberalismo -, de uma sociedade que há dezoito meses se esforça para realizar esse ideário. O liberalismo valoriza as liberdades do indivíduo, que serão sempre melhor exercidas uma vez que asseguradas as condições materiais de que tanto carece uma enorme maioria de nossos cidadãos - hoje, é chegado o momento de o liberalismo adquirir, no plano internacional, a consciência social que já incorporou em nível nacional. O liberalismo valoriza as liberdades do mercado, mas não prescinde de mecanismos que coíbam a distorção e o descumprimento de suas regras mais elementares, como as atuais políticas discriminatórias e protecionistas. Isto significa que a comunidade internacional terá de dedicar atenção política prioritária aos problemas do desenvolvimento".
}

\footnotetext{
${ }^{623}$ Seixas Corrêa, Luiz Felipe de. A Palavra do Brasil nas Nações Unidas. Brasília: FUNAG, 2007.

624 Idem, p. 532-3.
} 
O malogro político de Collor, entretanto, não tardaria a chegar. Na medida em que a crise doméstica se acentuava - tanto nos indicadores econômicos quanto na incapacidade de se estabelecer qualquer tipo de entendimento nacional - ficava mais custoso para o presidente atrelar, como fizera desde o princípio do governo, sua credibilidade à credibilidade internacional do Brasil. Aos poucos, Collor vai transferindo para a chancelaria - como já havia feito com Marcílio - a responsabilidade não só pela condução das políticas específicas, mas também prerrogativas de formulação que se encontravam, em larga medida, ausentes. Eis o momento em que autonomia e modernização, pela primeira vez, convergem plenamente. 


\section{CAPÍTULO 6}

\section{Autonomia e modernização}

Na entrada de 1992, os desgastes políticos acumulados por Collor de Mello forçaramno a empreender uma profunda recomposição de forças no seio do Executivo. Sucessivas acusações de corrupção atingiam importantes figuras do primeiro escalão ministerial, muitas das quais ligadas ao presidente. Na reunião de avaliação do segundo aniversário do governo, as denúncias contra sua equipe foram o tema central do discurso de Collor, que reiterou, com certo tom de ressentimento, seu compromisso "rigoroso, inabalável e indeclinável com a transparência, a lisura e a probidade administrativa" ${ }^{\prime 625}$. Era natural que o presidente estivesse ansioso com a deterioração, cada vez mais visível, de sua aprovação popular - minada não só pela corrupção, mas particularmente pelos índices econômicos desfavoráveis, como a inflação (que manteve, entre janeiro e março, uma média mensal de $24 \%{ }^{626}$ ).

A situação também tinha efeitos no tenso relacionamento entre Executivo e Legislativo. A relação de Collor com o Congresso, cujos desencontros se intensificaram pelo fracasso das reformas constitucionais propostas pelo "emendão", de fins do ano anterior, levou o país a uma profunda paralisia decisória. Nos altos círculos legislativos, já se falava em "crise de governabilidade" - termo que ganhou particular dramaticidade vindo de Ulysses Guimarães, ao propor, com urgência, o estabelecimento do parlamentarismo: "precisamos de uma cirurgia visceral, não de plástica visual: de bisturi, não de cosméticos maquiadores. A política no Brasil está errada" ${ }^{27}$. Necessitava-se, portanto, de uma aproximação urgente com os partidos políticos, que haviam sido alijados do governo desde seu princípio. Finalmente, a preocupação de Collor estava também relacionada à repercussão internacional das denúncias de corrupção, capazes de comprometer o sucesso da Rio-92 e de afugentar investidores estrangeiros $^{628}$.

\subsection{O sentido da nomeação de Celso Lafer}

Tendo este quadro em mente, pode-se interpretar a nomeação de Celso Lafer à chancelaria, em abril de 1992, a partir de duas leituras não excludentes. A primeira delas está

\footnotetext{
${ }^{625}$ O Globo, "Collor: corrupção não terá guarida", 14 de março de 1992, p. 3.

626 Índice Nacional de Preços ao Consumidor Amplo Especial (IPCA-E). Disponível em http://www.portalbrasil.net/ipca_e.htm. Acesso em 9/8/2014.

${ }_{627}$ Guimarães, Ulysses. "Sem cidadania não há democracia", 15 de março de 1992, p. 7.

${ }^{628}$ OESP, "Collor fará o mea-culpa da corrupção", 9 de março de 1992, p. 4.
} 
ligada à necessidade de compor um ministério mais próximo das forças partidárias, que poderiam assegurar sustentação ao presidente em tempos de turbulência política. Frisa-se, aqui, que Lafer não foi nem o primeiro, nem o segundo nome a ser sondado para substituir Francisco Rezek. Distintas fontes apontam que Fernando Henrique Cardoso, que já havia sido considerado no início do governo para a chancelaria (e vetado pelo PSDB), foi novamente abordado - e vetado novamente. Os tucanos permaneciam firmes na decisão de não compor um gabinete de coalizão com Collor, como o então senador Mário Covas (PSDB-SP) manifestou reiteradas vezes ${ }^{629}$, e tratavam a nomeação do sociólogo Hélio Jaguaribe fundador e filiado ao partido - para a Secretaria da Ciência e Tecnologia como um convite individual e realizado à revelia do próprio $\operatorname{PSDB}^{630}$.

Outros nomes aventados antes de Lafer foram os dos deputados federais Ulysses Guimarães (PMDB-SP) e Roberto Campos (PDS-RJ) e do embaixador em Washington, Rubens Ricupero. Ulysses, sondado em missão parlamentar ao continente africano (na qual negociava com lideranças locais a participação na Rio-92), declinou o convite à distância e mais tarde rechaçou qualquer participação do PMDB no governo: "tem que ficar alguém na tribuna para fiscalizar, para não ser só amém" ${ }^{631}$. Campos, diplomata experiente e parlamentar de longa data, sinalizou aceitar o convite, mas teve seu nome recusado após negociações entre o governo e o PDS, que acabou assumindo ministérios politicamente mais centrais ${ }^{632}$.

Ricupero, por sua vez, possuía as credenciais para assumir o Itamaraty a partir da perspectiva do fortalecimento da carreira diplomática, mas não gozava da simpatia do presidente da República ${ }^{633}$. Falava-se, também, dos riscos de desenraizar o embaixador de ligação com os Estados Unidos, envolvido nas negociações bilaterais mais sensíveis ${ }^{634}$. Sua consideração como ministeriável, contudo, aponta para nossa segunda hipótese sobre o significado da mudança no Itamaraty: após dois anos de governo, era necessário resgatar a "autoridade moral" do ministério sobre a política exterior. Rezek havia colecionado atritos com Collor e com as autoridades da área econômica, em função das dificuldades das relações com os Estados Unidos. Ademais, desde as reformas estruturais empreendidas pelo chanceler

\footnotetext{
${ }^{629}$ O Globo, "Covas ataca acordo com o Governo", 2 de abril de 1992, p. 3.

${ }^{630}$ O Globo, "Collor: dificuldade para trocar minsitros", $1^{\circ}$ de abril de 1992, p. 3.

${ }^{631}$ O Globo, "Rezek, o desprestígio no Palácio", $1^{\circ}$ de abril de 1992, p. 3.

632 Campos, Roberto. Lanterna na Popa. Rio de Janeiro: Topbooks, 1994, p. 1250. Campos, na mesma oportunidade, discute também a hipótese de seu nome ter sido vetado por Marcílio Marques Moreira, temeroso de que um diplomata com experiência em questões financeiras à frente do Itamaraty poderia abrir uma “diplomacia bifronte" entre a Economia e as Relações Exteriores, complicando ainda mais a já delicada situação das negociações da dívida.

${ }^{633}$ FSP, "Ricupero nunca foi um preferido de Collor", 10 de abril de 1992, p. 1-5.

${ }^{634}$ Campos, 1994, p. 1250.
} 
- a tripartição da Secretaria Geral e a "expulsória" - a relação entre o primeiro escalão diplomático e o governo haviam ficado abaladas. Mas havia um componente adicional: com sua credibilidade pessoal comprometida, o presidente necessitava capacitar outros interlocutores para representar a "cara" do país no exterior. Marcílio já desempenhava, parcialmente, essa função. O novo chanceler precisaria estar à altura deste papel.

Ao fim e ao cabo, Lafer preenchia ambos os requisitos. Do ponto de vista político, tratava-se de um membro fundador do PSDB, embora não participasse da militância. Formava, no entendimento de Roberto Campos, uma "frente informal" tucana de apoio a Collor, a que se somavam Jaguaribe e os tecnocratas econômicos Dorothéa Werneck e Roberto Macedo ${ }^{635}$. Do ponto de vista reputacional, Celso Lafer era um prestigiado acadêmico da Universidade de São Paulo, versado em política internacional, de inclinações fortemente liberais ${ }^{636}$, além de ligado a grandes grupos empresariais, como a Metal Leve.

O bom trânsito com o Itamaraty, com quem possuía "trajetória de permanente vinculação intelectual e afetiva”, nas palavras de Seixas Corrêa ${ }^{637}$, asseguraria a revitalização do alinhamento entre diplomacia, presidência e política exterior. As credenciais, por sua vez, lhe permitiriam contribuir para a restauração da credibilidade de um governo cuja reputação corroía-se diariamente. Não à toa, a ampla reforma ministerial empreendida por Collor - que durou, a bem da verdade, mais de três meses para ser concluída - apresentava, além do lado partidário mais pronunciado, o estabelecimento de um ministério de "notáveis", termo pelo qual a nova equipe ficou conhecida em sua fugaz formação. Novamente, a definição de Seixas Corrêa parece-nos adequada: "Homens que acreditavam no projeto de modernização do país e que viam no exercício do poder a possibilidade de dar uma contribuição objetiva para a sociedade, independentemente de qualquer consideração de natureza política”. Conclui o embaixador que Celso Lafer havia assumido as Relações Exteriores "em circunstâncias cruciais para as instituições e para a imagem externa do Brasil"

\subsection{O realinhamento entre discurso e prática diplomática}

Todos esses elementos faziam-se presentes no discurso de posse de Lafer, em 13 de abril de 1992. O novo chanceler reafirmou seu compromisso pessoal com o "liberalismo de

\footnotetext{
635 Ibidem.

${ }^{636}$ Ver, por exemplo, Lafer, Celso. Ensaios Liberais. São Paulo: Siciliano, 1991. Ver também Paim, Antonio. “Contribuição de Celso Lafer ao Liberalismo Brasileiro". Revista USP, no. 27, 1995.

${ }^{637}$ Seixas Corrêa, Luiz Felipe de. "Prefácio". In: Ministério das Relações Exteriores. A Inserção Internacional do Brasil: a gestão do Ministro Celso Lafer no Itamaraty. Brasília: MRE, 1993, p. 16.

${ }^{638}$ Idem, p. 22.
} 
inovação", que conjugava eficiência de mercado, liberdades políticas e pessoais, o primado da legalidade e, mais importante justiça social - ideias que caminhavam ao encontro das teses sobre o social-liberalismo esposadas pelo próprio presidente da República, nos jornais, nos meses anteriores ${ }^{639}$. Também ressaltou a necessidade de adequar a política exterior do Brasil aos tempos de incertezas, transformações e oportunidades - seguindo a máxima que ele próprio defendia em trabalhos anteriores, segundo a qual a política externa representava a conjugação de "possibilidades externas e necessidades internas" ${ }^{\text {640 }}$. Defendeu, abertamente, a necessidade de que as relações internacionais do Brasil fossem pautadas por uma "visão de futuro", na qual estivesse presente uma combinação de tradição e inovação. A tradição estaria ligada ao acervo da política externa, "os princípios fundamentais que marcaram historicamente nossa diplomacia, como o da solução pacífica das controvérsias, a igualdade soberana dos Estados, a autodeterminação e a não-intervenção". A inovação ligava-se às novas temáticas da política internacional, que exigiam do Brasil não somente "vontade de transformar", como também "um papel afirmativo no processo de reforma, ora em curso, da ordem mundial" 641 .

As palavras de Lafer, imbuídas de um misto de conservadorismo institucional e inovação principista (também, em algum sentido, conservadora), tinham o potencial de agradar ao presidente e, sobretudo, aos diplomatas. A seção final de seu discurso de posse representava um novo pacto entre chancelaria e a carreira diplomática:

\begin{abstract}
"Sei das dificuldades que o Itamaraty enfrenta. Cuidarei como meta prioritária de superá-las no mais breve prazo. Comprometo-me com a busca tempestiva de soluções duradouras e equitativas para os problemas institucionais e de carreira que afetam o funcionamento da Casa. A hora é de unir, de somar, de assegurar a harmonia e o sentido de excelência que sempre caracterizaram esta que é uma instituição permanente da Nação brasileira",642
\end{abstract}

$\mathrm{Na}$ prática, a nomeação de Celso Lafer resgatou a centralidade do Itamaraty na condução da política externa brasileira. Se, nos dois anos anteriores, houve certa dualidade entre os planos retórico (articulado pelo presidente) e operacional (conduzido, em frentes distintas e nem sempre coordenadas, pelos ministros das Relações Exteriores e da Economia), eles voltaram a se alinhar sob o novo chanceler. As circunstâncias, claro, eram as mais

\footnotetext{
${ }^{639}$ Para compilação completa dos textos sobre o social-liberalismo, ver Collor de Mello, Fernando. Proposta Social-Liberal. Brasília: Senado Federal, 2008.

${ }^{640}$ Lafer, Celso. O Brasil e a Crise Mundial. São Paulo: Perspectiva, 1984.

${ }^{641}$ Lafer, Celso. "Cerimônia de posse no cargo de Ministro de Estado das Relações Exteriores". In: Ministério das Relações Exteriores, 1993, p. 31-37.

${ }^{642}$ Lafer, 1993, p. 36.
} 
propícias: Collor, outrora centralizador e desejoso por personificar seus ministérios "modernizantes", saía forçadamente de cena; os contenciosos bilaterais com os Estados Unidos e com a comunidade financeira, outrora centrais à política externa brasileira e conduzidos, prioritariamente, pela equipe econômica, haviam sido encaminhados; soma-se a isso o fato de que, ao contrário do início do mandato, o quadro mundial apresentava-se, em algum sentido, mais incerto e mais dinâmico. Se a queda do muro de Berlim e a Guerra do Golfo haviam criado a sensação de que os Estados Unidos assumiam, por completo, a hegemonia global - ou aquilo que se chamou de "momento unipolar" norte-americano -, o ano de 1992 dava azo a novas interpretações sobre a estrutura e a lógica do sistema internacional $^{643}$. Uma delas, proposta pelo próprio Lafer, já fora da chancelaria, e do também ex-auxiliar de Collor, Gelson Fonseca Júnior, era a tese das "polaridades indefinidas", segundo a qual a vida internacional passou a sujeitar-se

“a forças profundas de duas lógicas que operam numa dialética contraditória e de mútua complementaridade: a lógica da globalização (das finanças, da economia, da informação, dos valores, etc.) e a lógica da fragmentação (das identidades, da secessão dos Estados, dos fundamentalismos, da exclusão social, etc.)",644 ${ }^{\text {. }}$

Caíam por terra, por conseguinte, as dicotomias relativamente sólidas que orientavam o pensamento internacional - e da própria diplomacia brasileira. A chegada de Collor à presidência havia representado a mudança da política externa ainda dentro de quadros conceituais conhecidos. Não houve tempo hábil para uma adaptação mais profunda das balizas que condicionavam a ação internacional do Brasil - e nem Collor nem Rezek tiveram condição de fazê-lo. Por isso mesmo, a guinada que o presidente buscou imprimir, alinhandose ao Primeiro Mundo (em oposição ao Terceiro), ainda se deu de maneira binária. Tanto que a passagem da retórica terceiro-mundista para primeiro-mundista, em março de 1990, e viceversa, em meados de 1991, foi evidência de que não havia um meio-termo possível em termos de orientação internacional - mesmo que, nas profundezas, no plano da ação diplomática

\footnotetext{
${ }^{643}$ Nos seis meses anteriores à chegada de Lafer à chancelaria, a União Soviética havia desaparecido, a fragmentação iugoslava deflagrava o início de um genocídio na Bósnia, dois golpes de Estado colocavam as aspirações democráticas em risco na Argélia e no Peru e as relações da República Popular da China com o mundo normalizavam-se com a adesão ao TNP e o fim das sanções econômicas impostas sobre ela pelos EUA. Ver Lessa, Antônio Carlos; Spektor, Matias e Chiarelli, Paulo José. "Cronologia das Relações Internacionais Contemporâneas e da Política Externa Brasileira". Cena Internacional, ano 2, no. 1, 2000, p. 198.

${ }^{644}$ Lafer, Celso. "Brasil: dilemas e desafios da política externa". Estudos Avançados, vol. 14, no. 38, 2000, p. 261. Ver também Lafer, Celso e Fonseca Jr., Gelson. "Questões para a diplomacia no contexto internacional das polaridades indefinidas (notas analíticas e algumas sugestões)". In: Fonseca Jr., Gelson e Castro, Sérgio H. N. (orgs.). Temas de Política Externa II. Brasília/São Paulo: Funag/Paz e Terra, 1994.
} 
muitas vezes silenciosa, houvesse muito mais tons de cinza do que os interlocutores domésticos ou internacionais poderiam identificar.

Isso significa, objetivamente, que o quadro das "polaridades indefinidas" demandava dos operadores diplomáticos brasileiros uma nova estratégia de inserção internacional, que não descurasse do tema fundamental proposto por Collor em sua posse - a modernização, ou integração competitiva - mas que articulasse, a um só tempo, as demandas sociais, os princípios diplomáticos fundamentais, e as oportunidades abertas nos interstícios de uma estrutura global em transformação. Às demandas domésticas, Lafer deu o nome de "agenda da opinião pública" - a articulação entre sociedade civil e política externa como um imperativo da democracia ${ }^{645}$. Às tradições da diplomacia brasileira, o novo chanceler propôs uma "adaptação criativa", significando uma nova atitude com relação aos regimes internacionais nos campos de tecnologias sensíveis, meio ambiente ou direitos humanos. O que estava em jogo, nesse caso, era reinterpretar o legado diplomático de Rio Branco, Rui Barbosa ou San Tiago Dantas à luz dos novos desafios planetários e do triunfo dos valores cosmopolitas ocidentais. Por fim, a permanente busca pela autonomia da política externa brasileira seria acrescida de medidas transformadoras, ou "ação para a mudança", expressão do desejo brasileiro pela democratização do sistema internacional e por um papel mais relevante do país no mundo ${ }^{646}$.

\subsection{Aspectos gerais da política externa de Fernando Collor e Celso Lafer}

O período de meados de abril ao início de outubro de 1992 foi marcado por uma importante inclinação multilateral da política externa brasileira. Em parte isso se relacionava com as próprias circunstâncias do sistema internacional: seja por indução dos Estados Unidos, em alguns casos (como na Guerra do Golfo), ou pela própria multipolaridade nascente em alguns temas ou agendas, o multilateralismo marca a entrada da década de 1990 e intensifica-

\footnotetext{
${ }^{645} \mathrm{O}$ tema do delicado equilíbrio entre política externa e democracia não será problematizado aqui, mas recomenda-se a leitura do profícuo debate que, recentemente, se estabeleceu sobre o assunto. Ver Lima, Maria Regina Soares de. “Instituições Democráticas e Política Exterior”. Contexto Internacional, vol. 22, no. 2, 2000; Pinheiro, Letícia. “Os véus da transparência: política externa e democracia no Brasil”. IRI Textos, no. 25, 2003; Oliveira, Amâncio e Onuki, Janina. "Eleições, partidos políticos e política externa no Brasil”. Política Hoje (UFPE), vol. 19, 2010; Belém Lopes, Dawisson. "A política externa brasileira e a 'circunstância democrática': do silêncio respeitoso à politização ruidosa”. Revista Brasileira de Política Internacional, vol. 54, no. 2, 2011; Belém Lopes, Dawisson. Política Externa e Democracia no Brasil: ensaio de interpretação histórica. São Paulo: UNESP, 2013.

${ }^{646}$ Lafer, Celso. “A inserção internacional do Brasil”. O Estado de São Paulo, 23 de maio de 1992, p. 2.
} 
se em seus primeiros anos ${ }^{647}$. Havia, também, o componente do pensamento diplomático que se readequava. O Brasil buscava sua autonomia, portanto, na construção ou atualização de regimes internacionais que abraçassem os "novos temas" globais - modernização do sistema internacional com a participação do Itamaraty.

Tal aspecto da modernização apresentava, como um de seus aspectos mais fundamentais, a democratização das regras do ordenamento mundial. Isso envolvia, por um lado, a reforma da Carta da ONU e de seu principal órgão decisório, o Conselho de Segurança, "de modo a permitir que a estrutura da organização reflita mais adequadamente as realidades da distribuição do poder internacional”. Para Lafer, a ampliação do Conselho com a inclusão de nações como Japão, Alemanha, Índia e Brasil - reforçaria a legitimidade do multilateralismo, fazendo-se “ainda mais premente pela 'regionalização' dos conflitos, que não mais dependem do eixo de confrontação Leste-Oeste, mas surgem de causas endógenas"

\begin{abstract}
“O processo de multilateralização das relações internacionais [acarreta] um outro aspecto da correlação diplomacia-democracia, que é o da progressiva codificação de diversos aspectos do convívio entre as nações. Os grandes temas das relações internacionais - mar, meio ambiente, direitos humanos, desarmamento (seja no campo nuclear, seja como agora no das armas químicas) - passam a ser codificados em significativas e abrangentes convenções com aspirações universais" "649
\end{abstract}

O envio de oficiais brasileiros a Operações de Manutenção da Paz das Nações Unidas foi um comportamento recorrente no período. Em fins de abril, o governo contribuiu com observadores para as Forças de Proteção da ONU (UNPROFOR) na Iugoslávia. Em junho, nove militares brasileiros foram destacados para a Missão Observadora da ONU em El Salvador (ONUSAL). No mesmo período, o Brasil juntou-se à comunidade internacional ao colocar em vigor sanções contra a Líbia (pela Resolução 748 do Conselho de Segurança) e contra o governo iugoslavo (Resolução 757). No plano hemisférico, decidiu-se também pela imposição de embargo econômico-comercial ao Haiti após a deposição do presidente JeanBertrand Aristide, em consonância com a decisão da Organização dos Estados Americanos ${ }^{650}$.

\title{
6.4. Meio ambiente como modernização
}

\footnotetext{
${ }^{647}$ Ver Huntington, Samuel P. “A Mudança nos Interesses estratégicos americanos”. Política Externa, vol. 1, no. 1, 1992; Patriota, Antonio de Aguiar. O Conselho de Segurança após a Guerra do Golfo: a articulação de um novo paradigma de segurança coletiva. Brasília: FUNAG, 1998.

${ }^{648}$ Lafer, Celso. "Perspectivas e possibilidades da inserção internacional do Brasil". Política Externa, vol. 1, no. 3, 1992, p. 108.

${ }^{649}$ Lafer,

${ }^{650}$ Los Angeles Times, “Haiti: embargo may be lifted even without president's return”, 15 de agosto de 1992.
} 
A Conferência das Nações Unidas sobre Meio Ambiente e Desenvolvimento (CNUMAD) - que ficaria conhecida como Rio-92 - realizou-se entre 3 a 14 de junho de 1992, dando início ao ciclo de grandes conferências internacionais sobre os "novos temas", patrocinadas pela ONU. O contexto internacional era bastante propício, por um lado, uma vez que não mais subsistia a lógica das polaridades definidas do período da Guerra Fria, abrindo espaço para uma cooperação internacional mais abrangente, orientada por uma "kantiana razão abrangente da humanidade" ${ }^{\natural 51}$. Por outro lado, havia certo pessimismo que se revelava tanto na conjuntura global, cujo horizonte já não se mostrava mais tão otimista quanto na virada da década, quanto na agenda da Conferência em si.

No que se refere às circunstâncias, aponta Lindgren Alves como fatores de instabilidade sistêmica "a cissiparidade de antigos Estados socialistas plurinacionais, a consequente multiplicação de novos membros das Nações Unidas, os conflitos na antiga Iugoslávia com níveis de virulência difíceis de compreender e a própria aceleração da globalização econômica”. Sobre a temática em si, pairava certa ansiedade, por parte das nações subdesenvolvidas, de que a questão ambiental revivesse - a partir da lógica do "direito de ingerência" sobre temas e problemas desconectados, a rigor, da pauta tradicional de segurança internacional - a clivagem Norte-Sul, agora ancorada numa visão reducionista e preconceituosa dos problemas ecológicos, consubstanciadas na crítica sistemática das potências industrializadas às mazelas ambientais do Terceiro Mundo ${ }^{652}$.

Se a diplomacia brasileira ganhou centralidade a partir da chegada de Celso Lafer, a realização da Conferência das Nações Unidas sobre Meio Ambiente e Desenvolvimento representou o ponto alto da estratégia da autonomia pela modernização. A autonomia manifestava-se na defesa incondicional do desenvolvimento, faceta da política externa brasileira associada à sua dimensão de Terceiro Mundo. A modernização, por sua vez, via-se representada na atualização irreversível da agenda internacional do Brasil em direção à ecologia, em linha com os anseios - e os desafios - dos países de Primeiro Mundo. Não era trivial, portanto, a recorrente menção a Roger Bastide - que descrevia o país como "terra de contrastes" - sempre que Lafer queria prover uma síntese das possibilidades de atuação externa do Brasil.

Não se tratava, contudo, de uma defesa irrefletida do conceito de desenvolvimento sustentável, consagrado na Conferência do Rio. Para além da síntese que essa ideia

\footnotetext{
${ }^{651}$ Lafer, Celso. "O Significado da Rio-92 e os Desafios da Rio+20”. Política Externa, vol. 21, no. 1, 2012.

${ }^{652}$ Alves, 2006, p. 59
} 
representava - reproduzindo formulações sutilmente diferentes, como aquela de que não se pode viver num mundo ambientalmente sustentável e socialmente injusto -, o que marca a atuação brasileira no debate ecológico é a capacidade, como raras vezes se viu, de liderar um regime internacional a partir de um conceito fortemente influenciado pelo próprio Brasil ${ }^{653}$. Ou seja, da modernização econômica pela qual o governo Collor vinha batalhando nos últimos dois anos (e cujas derrotas eram numerosas, como vimos nos capítulos anteriores), deslocou-se a prioridade da agenda para a atualização e o ativismo internacional brasileiro no campo das normas internacionais. Nas palavras do embaixador Pinto Coelho,

\begin{abstract}
"A responsabilidade de países de grande dimensão territorial, ou com grandes patrimônios ambientais (uma e outra coisa em geral coincidindo), como Brasil, China e Índia, se destaca. Cabe-nos aproveitar essa vantagem relativa, que nos coloca em posição privilegiada nos exercícios de formulação de política internacional, e nesse sentido nos interessa fazer valer a agenda ambiental no quadro maior das relações internacionais. A proposta brasileira de sediar a UNCED foi coerente com essa percepção, que haveria de cuidar para não ser apenas episódica (...). Os meios, entretanto, estão à nossa disposição para proteger e usar racionalmente os nossos espaços. O paradigma do desenvolvimento sustentável, contrariamente a uma visão restritiva do desenvolvimento, resgata, articuladamente, os interesses dos países do Sul em manter seu compromisso básico com o desenvolvimento. Souberam esses países contribuir para a elaboração do conceito e do novo modelo, usando forças adversas a seu favor. Por isso mesmo, a agenda ambiental representou, e ainda representa, apenas um ensaio de espaço ideológico. Sua concretização como elemento efetivo de projeção de poder político nas relações internacionais será neutralizada, dificultada ou facilitada pela forma mais ou menos efetiva com que os países do sul souberem valorizar e aplicar a equação básica acertada no Rio" ${ }^{\text {654. }}$.
\end{abstract}

\title{
6.5. Integração como modernização
}

No tocante à integração regional, a gestão Celso Lafer herdou um marco institucional e um processo de negociação em curso. De todo modo, é no período de abril a setembro que ocorrem dois importantes episódios relativos ao Mercosul. O primeiro deles é a consolidação da aproximação com a Comunidade Econômica Europeia ${ }^{655}$, cujo processo já vinha se desenrolando desde o ano anterior - a cargo do Itamaraty, do lado brasileiro. A primeira reunião de chanceleres ocorrera em abril de 1991, em Luxemburgo, imediatamente após a

\footnotetext{
${ }^{653}$ Um caso que vem à mente é o da atuação diplomática brasileira na I Conferência das Nações Unidas para o Comércio e Desenvolvimento (UNCTAD), em circunstâncias políticas igualmente turbulentas, na definição da ideia-força do desenvolvimento econômico, mais tarde incorporado aos debates do GATT. Ver Cervo e Bueno, 2002.

${ }^{654}$ Coelho, Pedro Motta Pinto. "O Tratamento Multilateral do Meio Ambiente: ensaio de um novo espaço ideológico". In: Fonseca Júnior, Gelson e Nabuco de Castro, Sérgio Henrique (orgs.). Temas de Política Externa Brasileira II, vol. I. São Paulo: Paz e Terra, 1997, p. 261-2.

${ }^{655}$ O Tratado de Maastricht, que originou a União Europeia, foi assinado em 7 de fevereiro de 1992, mas somente entrou em vigor no ano seguinte.
} 
assinatura do Tratado de Assunção. Em paralelo às conversas com autoridades europeias destinadas à assinatura de um acordo nos moldes do $4+1$, havia também negociações com o governo japonês, conduzidas pelo chefe do Departamento Econômico do MRE, Celso Amorim $^{656}$.

A segunda reunião entre ministros dos dois blocos econômicos ocorreu em Guimarães, Portugal, no dia 4 de maio de 1992. No comunicado à imprensa após a Reunião Ministerial CE/Mercosul, destacou-se o objetivo mútuo de promoção dos direitos humanos e dos princípios democráticos e a necessidade de se aprofundarem as reformas liberalizantes dos países do Cone Sul. Os ministros declararam, por fim, a intenção de se assinar um acordo inter-institucional entre as duas regiões ${ }^{657}$. O Acordo de Cooperação Interinstitucional entre a Comissão da $\mathrm{CE}$ e as instituições do Mercosul, destinado a propiciar "um amplo intercâmbio de experiências e apoio recíproco entre as duas áreas de integração", foi finalmente assinado em 29 de maio, em encontro paralelo à reunião do Grupo do Rio com a CEE, em Santiago do Chile.

A segunda Cúpula Presidencial do Mercosul foi realizada em Las Leñas, na Argentina, entre os dias 26 e 27 de junho de 1992. Foi uma das últimas viagens presidenciais realizadas por Collor, que já se encontrava em situação política irreversível em função das denúncias de corrupção e da abertura do processo de impeachment no Congresso. Contra esse pano de fundo, a declaração dos presidentes de que a plena vigência das instituições democráticas era um pressuposto indispensável ao Mercosul ganha outra conotação: de acordo com alguns autores, diante da crise política envolvendo o presidente, havia riscos de ruptura democrática $^{658}$. Ademais, estabeleceu-se um cronograma de trabalho para acelerar o processo integracionista e viabilizar seus passos no tempo comprometido, que também objetivava o cumprimento da coordenação de políticas macroeconômicas e a solução de problemas de assimetrias comerciais e regulatórias. Decidiu-se, por fim, pela instalação de um Procedimento de Queixas e Consultas sobre Práticas Desleais de Comércio para os produtores locais.

Como se vê, o que estava em jogo na cúpula presidencial de Las Leñas era o ritmo dos próximos passos da integração. Objeto das discussões de alto nível, o cronograma estabelecia medidas coordenadas em cinco áreas: coordenação macroeconômica; políticas setoriais e

\footnotetext{
${ }^{656}$ FSP, "Brasil discute tratado entre Mercosul e CEE", 25 de junho de 1991, p. 1-7

${ }^{657}$ MRE, "Comunicado de Imprensa da Reunião Ministerial CE/MERCOSUL em Guimarães, Portugal”. In: MRE, 1993, p. 257-8.

${ }^{658}$ Zaverucha, Jorge. Frágil Democracia: Collor, Itamar, FHC e os Militares”. Rio de Janeiro: Ed. Civilização Brasileira, 2000.
} 
arranjos institucionais; tarifa zero e externa comuns; definição de política aduaneira; e zona de livre comércio ${ }^{659}$. O subsecretário de Assuntos Econômicos do Itamaraty e negociador do Mercosul, Rubens Barbosa, sustentou que o processo de integração coincidia com as políticas de ajuste realizadas pelos quatro países, o que indicava que as reformas estruturais necessárias ao aprofundamento do bloco seriam empreendidas de maneira coordenada. Com efeito, a declaração presidencial do Mercosul, emitida ao final do encontro, reiterava a centralidade do Cronograma de Medidas (que ficou conhecido como "Cronograma de Las Leñas"), aprovado pela decisão no. 01/92 do Conselho do Mercado Comum, como "um feito fundamental na conformação do Mercosul", ratificando "a vontade dos governos dos Estados-partes de concretizar o Mercosul dentro dos prazos previstos, já que compromete tarefas e datas concretas para alcançar os objetivos de integração". Além disso, em seus pontos 2 e 3, a declaração afirmava "a plena vigência das instituições democráticas" e "a economia de mercado, a estabilidade com crescimento, a abertura e a modernização das economias" como supostos indispensáveis à existência do bloco ${ }^{660}$. Em suma, de acordo com Vaz, a reunião de Las Leñas concluiu "a etapa em que se definiram as bases e se delimitaram as áreas e a agenda da negociação e na qual se deu início à implementação das decisões políticas consubstanciadas na Ata de Buenos Aires, no ACE-14 e, notadamente, no Tratado de Assunção" $" 661$.

Antes do início da cúpula, os quatro presidentes do Mercosul - mais seus pares de Bolívia e Chile, presentes na reunião - manifestaram sua preocupação com a decisão da Suprema Corte norte-americana de permitir que os Estados Unidos sequestrassem um cidadão estrangeiro em território estrangeiro e julgassem-no pelas leis federais dos EUA, mesmo que entre os dois países houvesse um tratado de extradição ${ }^{662}$. Em comunicado conjunto, seguindo recomendação da delegação chilena, os países do bloco solicitaram ao Comitê Jurídico da OEA um parecer sobre a validade jurídica da decisão do Judiciário estadunidense ${ }^{663}$. Na opinião do chanceler argentino, Guido di Tella, tratou-se de uma "resposta positiva" que manifestava a indisposição das nações sul-americanas em aceitar decisões que colocassem em risco suas soberanias nacionais ${ }^{664}$.

\footnotetext{
${ }^{659}$ OESP, “Começa hoje, em Las Leñas, a reunião de cúpula do Mercosul”, 26 de junho de 1992, p. 7.

${ }^{660}$ Mercosur. "Comunicado de Las Leñas", 27 de junho de 1992. Revista de Relaciones Internacionales, no. 3 , 1992. Disponível em http://www.iri.edu.ar/revistas/revista_dvd/revistas/R3/R3DOC07.html ${ }^{661}$ Vaz, 2002, p. 195.

${ }^{662}$ NYT, "Excerpts from Supreme Court's Decision on the Kidnapping of Foreigners", 16 de junho de 1992.

663 "Declaração dos Países do Cone Sul”, 30 de junho de 1992. In: MRE, 1993, p. 267.

${ }^{664}$ Devoto, Leonor Machinandiarena de. Historia del MERCOSUR: desde su fundación hasta el año 2000. Buenos Aires: CIEG, 2006, p. 17.
} 
Dez dias depois da reunião de Las Lenãs, aos 8 de julho de 1992, o jornal argentino $L a$ Nación publicou, na qualidade de "espaço de publicidade", um suplemento de quatro páginas sobre a ALADI. Na primeira página, uma nota assinada pelo presidente Menem, com os seguintes dizeres: "onze países em direção ao Mercado Comum. Vinte milhões de quilômetros quadrados, quatrocentos milhões de habitantes". O texto fazia ode à América ibérica, unida pelo idioma e pela fé, e falava da integração latino-americana (não do Cone Sul) como o destino natural da região rumo a um mundo multipolar. As demais notas eram assinadas pelo presidente do Comitê de Representantes da ALADI, o Secretário Geral, o embaixador argentino junto à Associação, o presidente do BID, o subsecretário do Mercosul, o presidente da União Industrial Argentina (UIA) e funcionários do governo, como Domingo Cavallo, além dos secretários de Ciência e Tecnologia e de Turismo. Em nenhum lugar constava quem havia financiado o suplemento, seu objetivo, ou a que data comemorativa aludia. Por outro lado, as notas deixavam claro que o Mercosul havia sido concebido dentro da ALADI e dela era parte. Em algumas delas, como no texto assinado pelo ministro Cavallo, exortava a necessidade de potencializar a inserção da economia argentina no mercado norteamericano, sob o guarda-chuva da Iniciativa para as Américas ${ }^{665}$.

Essa leitura joga luz sobre a avaliação de Marcos Azambuja - que a escreve já findado o governo Collor, agora na qualidade de embaixador em Buenos Aires -, para quem era fundamental que não houvesse

\footnotetext{
"uma dispersão de esforços, seja para incorporação de novos parceiros, seja pela identificação de outros objetivos, por mais relevantes ou sedutores que pareçam. Seja o Nafta, seja uma Zona de Livre Comércio na América do Sul (...), importa é que, no curtíssimo prazo, nada dissipe a intensidade do nosso foco na construção do Mercosul, e que grandes projetos que concebamos juntos, ou que sejamos convidados por outros a aderir, nasçam de um Mercosul já consolidado (...." ${ }^{\text {} 666}$.
}

Em linha com a discussão realizada no capítulo 4, vê-se que o Mercosul, pela própria natureza assimétrica das economias que o constituem, tinha incentivos claros para tornar-se um projeto eminentemente brasileiro, em sintonia com a ideia de "integração competitiva". A Argentina, embora não negasse a centralidade da empreitada integracionista - até mesmo por ter representado o fim da rivalidade bilateral com o Brasil - tinha razões ideológicas e pragmáticas para tentar diluir a iniciativa, incorporando-a ao Plano Bush ou buscando, no

\footnotetext{
${ }^{665}$ Devoto, 2006, p. 18-20.

${ }^{666}$ Azambuja, Marcos Castrioto de. “O Relacionamento Brasil-Argentina: de rivais a sócios”. In: Fonseca Júnior, Gelson e Castro, Sérgio Henrique Nabuco de. Temas de Política Externa Brasileira II, volume 2. Brasília/São Paulo: FUNAG/Paz e Terra, 1997, p. 70.
} 
nível bilateral, acordo com os Estados Unidos semelhante ao que haviam assinado com México e Canadá. A consolidação institucional que se vê nos anos seguintes - culminando no Protocolo de Ouro Preto, de 1994 - é sinal dos esforços diplomáticos brasileiros e, mais que isso, evidência de que, ao menos da parte do Brasil, trata-se de projeto de longo prazo, não se encerrando nos anseios de um presidente ou governo. 


\section{Considerações finais}

O melancólico fim do governo Collor - processo que se arrastou de setembro de 1992, com o afastamento do presidente da República, até sua renúncia, em fins de dezembro retirou, temporariamente, os holofotes das questões internacionais envolvendo o Brasil. A crise política em que o país se encontrava causou um momento importante de introspecção, em que não somente se repensaram os objetivos da política exterior, à luz da experiência dos dois anos e meio do presidente Collor de Mello, como também seus meios. Com relação aos objetivos, ficaram claros os riscos de qualquer tipo de adesão unilateral às exigências dos Estados Unidos, mesmo quando tais atos pareciam desanuviar o relacionamento e garantir ganhos de longo prazo. Essa aposta, ao fim e ao cabo, mostrou-se perigosa, confirmando mais do que nunca a máxima realista de que "Estados não têm amigos, somente interesses".

A simpatia com que o governo Bush tratou o governo Collor, antes mesmo da posse e durante seus primeiros meses, rapidamente esvaiu-se, dando lugar a uma série de pressões canalizadas nos EUA, mas provenientes dos bancos credores, da indústria farmacêutica, dos organismos financeiros internacionais, de ambientalistas ou empresários - que rapidamente minaram a capacidade brasileira de resistir a uma agenda que lhe estava sendo imposta de cima para baixo. Não se pode perder de vista que o Brasil já estava no centro das críticas internacionais em diversas frentes simultâneas no decorrer dos anos 1980, da dívida à ecologia, das patentes aos direitos de minorias. Com efeito, parte da crise política e econômica pela qual passou o Brasil entre 1990 e 1992 foi compreendida como consequência de escolhas erradas em matéria de política externa, não como variável interveniente que enfraquecia a posição brasileira diante dos constrangimentos sistêmicos. Retoricamente, acadêmicos, políticos e diplomatas construíram a narrativa de que o governo Collor, além de todos os problemas a que se relacionava domesticamente, havia cometido equívocos graves em sua orientação internacional. Era necessário, portanto, reformular completamente a política externa a partir de então, buscando uma síntese entre um passado bem-sucedido - da era desenvolvimentista e que atingira seu ápice no governo Geisel, por exemplo - e os desafios do futuro. Negar o legado de Collor era a primeira coisa a se fazer.

Sugerimos, a título de conclusão, que a negação à política externa de Collor não se concretizou para além da retórica. Por mais traumático que tenha sido seu governo, contra o qual muitos ainda hoje reagem calorosamente, deve-se olhar com atenção a síntese conceitual que se desenhou ao longo daquele "projeto de voo curto". Muitos autores, conforme resenhado no capítulo 1 , creem que a orientação internacional daquele governo orientou-se 
pelo antigo paradigma do americanismo, sugerindo certo grau de alinhamento automático que, quanto maior o grau atribuído, maior sobre o juízo (negativo) a respeito do período. Esta tese, ao contrário, buscou oferecer uma abordagem sobre a política externa do governo Collor que é, ao mesmo tempo, inédita do ponto de vista conceitual e inovadora do ponto de vista empírico. O americanismo mitigado que transparece quando se encara o período a partir de uma lente macroscópica vai se tornando uma ideia mais refinada, de autonomia pela modernização, que se manifesta de maneiras distintas em cada um dos quatro períodos delineados pela tese - periodização que, aliás, parece-nos ser um dos ganhos empíricos trazidos por esse trabalho.

Com relação ao conceito, é importante demarcar, aqui, as diferenças que estabelece com outras formulações semelhantes, que vêm somar ao já amplo rol de estratégias de autonomia. Antes de tudo, deve ficar claro que não tomamos a noção de autonomia como estanque ou absoluta; pelo contrário, mais do que completa independência de ação no cenário internacional - circunstância impraticável pela própria dinâmica de poder que estrutura a política mundial - a autonomia revela-se, na prática, como a tentativa de reduzir as pressões sistêmicas sobre si, de modo a viabilizar a concretização de objetivos nacionais sem que sejam esgarçados pelos constrangimentos externos. Trata-se, no limite, de conceito defensivo, que se aproxima da heteronomia kantiana no sentido da internalização das regras internacionais em vez da sujeição pura e simples. Além disso, devemos ressaltar que o desejo por autonomia que se manifesta na política externa brasileira não se traduz, na prática diária, em ações concretas. A política externa de um país é constituída por uma série de processos complexos, que envolvem concessões, retrocessos, alguns de caráter tático, outros que deixam sua marca permanente. Autonomia é a baliza, não necessariamente o resultado de tudo o que um país faz no mundo.

Dito isto, e voltando à questão das regras, deve-se compreender como se manifesta a autonomia utilizando-se da estratégia de modernização. Se, num mundo caracterizado pelas assimetrias de poder - esteja ele manifesto em poder material ou ideacional - o máximo que um país pode fazer é reduzir os efeitos sistêmicos sobre si (minimizando, portanto, a condição de heteronomia), ele deve potencializar a construção de espaços próprios de atuação por meio da intervenção direta nas regras internacionais. Em outras palavras: em sendo inevitável a internalização de regras de conduta no plano global, que ao menos o país seja capaz de moldálas, na medida do possível, em seu benefício próprio.

Seria isso possível no caso do Brasil, uma potência média, de industrialização recente e marcada por profundas desigualdades e vulnerabilidades de fundo? Ao contrário do que reza 
a literatura realista de Relações Internacionais, acreditamos que sim, especialmente no momento histórico em que essa tese se debruça. As rápidas transformações globais abriam espaço para os chamados "novos temas" - dentre os quais a não-proliferação, o terrorismo, os direitos humanos e o meio ambiente. Num mundo em que a utilidade do poderio militar vinha aparentemente decrescendo (mesmo que, posteriormente, alguns tenham querido provar o contrário), as novas temáticas assumiam importante papel no relacionamento entre Estados e nas demais interações características de um planeta mais integrado e globalizado - fluxos de bens, pessoas, investimentos e ideias - para ficarmos na conceituação mais tradicional da interdependência complexa - articulados pelo crescente ativismo de atores transnacionais e supranacionais. Buscamos adaptar, no capítulo 1, o modelo analítico proposto por Maria Regina Soares de Lima com vistas a compreender a política externa num período de transição, mas conservando o pressuposto básico de que o Brasil, na qualidade de potência média, estava particularmente suscetível aos efeitos sistêmicos que se encontravam em marcha.

O momento era de construção de novas regras de conduta globais, formalizadas em regimes internacionais, como aqueles que nasceram da Cúpula da Criança, de 1990, e da Conferência do Rio, em 1992. A janela de oportunidade encontrava-se aberta para países médios, mas com algum diferencial ligado a algum dos temas específicos, contribuírem na conformação desses novos parâmetros. No começo, isso pode ter assumido conotação diversa, puramente defensiva, como no caso da proposta brasileira de sediar uma cúpula ambiental em meio a intensas críticas à maneira como o próprio país vinha cuidando do seu próprio meio ambiente. Não se abandonou imediatamente, como se sabe, a postura soberanista da política externa brasileira em questões como essa. Aos poucos, entretanto, o Brasil vai descobrindo interstícios nos quais atuar, tornando-se, ao fim do processo, um rule-maker incipiente em vez de um rule-taker contrariado.

Pode-se afirmar que, no contexto da política externa do governo Collor, a exploração desses espaços normativos abertos veio de maneira quase intuitiva. Aqui entra a inovação empírica da tese, que envolve demonstrar, com base em documentação primária, como a agenda internacional de Collor - candidato, presidente-eleito, presidente - foi se constituindo, à luz das influências sistêmicas. Como demonstramos no capítulo 2, ainda candidato, Fernando Collor de Mello explorou ao máximo a liberdade de ação que teve em sua viagem à Europa para propor, descompromissadamente, algumas ideias que lhe pareciam adequadas como político. Importante lembrar que ele queria, a um só tempo, construir sua própria identidade política a partir de referências marcantes europeias, como Margaret Thatcher ou Felipe González, e demarcar seu posicionamento em oposição ao que vinha sendo o governo 
Sarney. Não surpreende, portanto, que Collor tenha captado as demandas sistêmicas direcionadas ao Brasil - sem filtros conceituais anteriores - e transformado-as em proposições sujeitas ao escrutínio das lideranças internacionais. Ao longo da campanha, foi descobrindo as limitações dessa estratégia, sob pena de parecer ingênuo ou até mesmo ignorante em questões internacionais (como se viu, por exemplo, na questão Israel-OLP). Chegou ao final do processo eleitoral de 1989 com ideias muito mais claras e ajustadas tanto à realidade internacional quanto ao repertório da própria diplomacia brasileira. Não é exagero sugerir que, da campanha, nasce uma ideia, ainda que bruta, de modernização - traduzida, num primeiro momento, em termos de integração competitiva, por exemplo.

As viagens de presidente-eleito, abordadas no capítulo 3, já demonstram a Collor com mais clareza que o discurso de modernização em si não seria a panaceia para os gargalos internacionais herdados por seu governo. Autonomia seria a resultante de uma delicada negociação, que não dependia somente da simpatia das potências industrializadas - até mesmo porque elas trabalhavam, muitas vezes, no sentido contrário ao dos interesses brasileiros em temas como dívida externa, propriedade intelectual ou meio ambiente. A boa impressão causada internacionalmente, contudo, poderia ser um importante elemento de barganha para que o Brasil, uma vez recomposto em termos econômicos, pudesse ampliar seus espaços de atuação internacional, abandonando a posição defensiva que caracterizara, em linhas gerais, a política externa brasileira na década anterior. O ingresso no Primeiro Mundo não viria somente pela retórica, embora os compromissos retóricos fossem fundamentais para viabilizar as mudanças substantivas - no plano doméstico, mas com impactos sobre as relações bilaterais do Brasil - que poderiam conduzir o país a uma nova relação entre Estado e sociedade, a "integração competitiva", que asseguraria a autonomia brasileira no médio prazo.

O capítulo 4, por sua vez, dedicou-se à exploração da complexa agenda internacional do Brasil na virada da década, mostrando como o governo Collor buscou conciliar uma retórica modernizadora - centrada em sua própria figura, em função da credibilidade adquirida junto aos interlocutores estrangeiros - com resistências focalizadas, como forma de controlar as concessões que eram feitas às demandas das potências industrializadas, em geral, e dos Estados Unidos, em particular. O sentido da política externa em sua dimensão simbólica - viagens presidenciais, discursos, parceiros preferenciais - era claramente orientado ao Primeiro Mundo e aos parceiros da América Latina, muitos deles passando por processos políticos e econômicos semelhantes aos nossos. Não obstante, uma leitura cuidadosa de certos processos revela como, nas ações de longo prazo e centrais à agenda de modernização 
brasileira, a diretriz geral foi a resistência. Cedeu-se nos temas das patentes e da informática, por exemplo, em busca de protelar as negociações da dívida, muito mais desgastantes e custosas ao país. Cedeu-se na disposição de negociar com os Estados Unidos um marco geral de cooperação comercial nos termos do Plano Bush, para assegurar a consolidação e a viabilidade do Mercosul. Cedeu-se pontualmente na não-proliferação, em timing descoordenado em decorrência da Guerra do Golfo, para que se mantivessem as diretrizes centrais da política externa brasileira - não-intervenção, soberania e universalismo. A "crise dos reféns" do Iraque pode ser compreendida como um elemento catalizador desse processo.

As concessões realizadas pelo Brasil, sobretudo aos Estados Unidos, foram insuficientes. No contexto de afirmação do seu poder hegemônico, ao menos em sua faceta política, o governo Bush seguiu pressionando as autoridades brasileiras, inclusive em áreas em que o Brasil já tinha realizado aberturas importantes, mas que dependiam de autorização legislativa (como o caso das patentes) ou cujo tempo do processo não era totalmente de controle do país, principalmente quando envolviam negociações triangulares (como o caso da dívida). A condição doméstica brasileira, que se deteriorava e culminou na demissão da ministra Zélia, em maio de 1991, demarcou a incapacidade brasileira de resistir. Como vimos no capítulo 5, quando as concessões mais dolorosas começaram a aparecer, a insatisfação do presidente - falando em nome da política externa brasileira - é convertida em discurso contestatório, terceiro-mundista. A nova retórica, tributária do universalismo de outros tempos, funcionou como um mecanismo compensatório ao que o Brasil cedia, principalmente na área econômica. No front da integração, o Itamaraty, devidamente respaldado pelo presidente, esforçava-se para manter o Mercosul unido, diante da ansiedade argentina por unir-se às tratativas do NAFTA.

Se o desejo de Collor, ao imprimir uma guinada no discurso, era aproximar-se concretamente de outros parceiros, ou de apaziguar a opinião pública doméstica, seus esforços foram praticamente todos em vão. A "reconstrução nacional" a que havia se proposto encontrava, em fins de 1991, barreiras econômicas, sociais, políticas e externas. Em busca de um entendimento nacional, o presidente ainda tentou sofisticar a retórica, abraçando o conceito de social-liberalismo, que divulgou internacionalmente no discurso da ONU e domesticamente nos jornais de grande circulação: uma maneira de contestar a ordem vigente sem confrontá-la, ou de adequar-se à ideologia dominante sintetizando-a à realidade nacional. O agravamento da crise, entre fins de 1991 e o início de 1992, não permitiu que Collor fosse longe com sua nova ideologia. Transferiu, logo que pôde, as prerrogativas e o protagonismo 
de seu governo para figuras que, reunidas em seu ministério, passaram a ser chamadas de "notáveis".

Os impactos que o estabelecimento desse ministério de notáveis trazem à política externa são explorados no capítulo 6. Chegamos à síntese conceitual que vinha fermentando desde as primeiras viagens internacionais de Collor. Ao conceder ao Itamaraty o protagonismo na formulação da orientação internacional do Brasil, o princípio da autonomia pela modernização atinge seu auge. As circunstâncias eram favoráveis: a Rio-92 garantiu, ao menos no decurso da conferência, um papel central ao Brasil como promotor do diálogo, construtor de pontes entre o Norte e o Sul, em função de sua própria natureza. Ao abraçar a ecologia não somente de maneira defensiva, mas propositiva, o país contribuía mais para a construção de uma nova ordem do que mandando fragatas para o Golfo Pérsico. Ao concluir e aprofundar a integração regional, mesmo com resistências vindas da Argentina e dos Estados Unidos - ambos, por razões distintas, desejosos por diluir a iniciativa, que havia adquirido forte caráter político ao Brasil - o país dá passos importantes rumo à integração competitiva, ideia que residia nas origens do discurso de modernização, e que dele nunca se dissociou. Remodelado, o conceito de autonomia pela modernização ganhará novas cores - integração, participação - que no fundo não representam ruptura, mas evolução a partir dos pressupostos básicos ali estabelecidos.

Se o tempo ainda não foi capaz de dar razão a Collor, ao menos na cabeça da grande maioria dos brasileiros que viveram seu governo e dele guardam recordações negativas, ele ao menos nos permite jogar luz sobre um momento pouco explorado das relações internacionais do Brasil, de modo a percebermos, ao fim e ao cabo, que muitos dos paradigmas que hoje orientam nossa política externa nascem ali, mesmo que tenham atingido pleno voo em períodos posteriores. 


\section{REFERÊNCIAS BIBLIOGRÁFICAS}

“Declaração dos Países do Cone Sul”, 30 de junho de 1992. In: MRE, 1993.

“Plano Collor". Revista de Economia Política, vol. 10, no. 3 (39), 1990.

ABACC. "Acordo entre a República Federativa do Brasil e a República Argentina para o uso exclusivamente pacífico da energia nuclear". Disponível em http://www.abacc.org.br/wpcontent/uploads/2011/07/acordo_bilateral_pt.pdf. Acesso em 25/09/2014.

ABREU, Alzira Alves de; LAMARÃO, Sérgio (orgs.). Personalidades da Política Externa Brasileira. Brasília: FUNAG, 2007.

ADLER, Emanuel. "O Papel das Elites Políticas e Intelectuais e das Instituições no Desenvolvimento da Informática e da Energia Nuclear na Argentina e no Brasil”. Dados, vol. 31, no. 3, 1988.

ALBUQUerQue, José Augusto Guilhon de et. alii (orgs.). Sessenta Anos de Política Externa Brasileira, vol. 1. $2^{\mathrm{a}}$. edição. Rio de Janeiro: Lúmen Juris, 2006.

ALBUQUERQUE, José L. C. "Campesinos paraguayos y 'brasiguayos' em la frontera este del Paraguay". In: FOGEL, Ramon e RIQUELME, Marcial. Enclave sojero, merma de soberania y pobreza. Assunção: CERI, 2005.

ALI, Tariq. "A beacon of hope for the rebirth of Bolívar's dream". The Guardian, 9 de novembro de 2006.

ALLISON, Graham T. "Conceptual Models and the Cuban Missile Crisis". The American Political Science Review, vol. LXIII, no. 3, 1969.

ALMEIDA, Monica Piccolo. "José Guilherme Merquior e Fernando Collor de Mello: o moderno liberalismo social". $2008 . \quad$ Disponível em http://www.escuelaaustriaca.org/Docs/Papers/EA2008/Piccolo\%20Ponencia.pdf

ALMEIDA, Paulo Roberto de. "Do Alinhamento Recalcitrante à Colaboração Relutante: o Itamaraty em tempos de AI-5". In: FREITAS, Jacqueline Ventapane et al. (orgs.). 'Tempo Negro, Temperatura Sufocante': Estado e Sociedade no Brasil do AI-5. Rio de Janeiro: Ed. Contraponto, 2008.

ALMEIDA, Paulo Roberto de. Relações internacionais e política externa do Brasil: a diplomacia brasileira no contexto da globalização. Rio de Janeiro: LTC, 2012.

ALVES, José Augusto Lindgren. Relações Internacionais e temas sociais: a década das conferências. Brasília: IBRI, 2001.

AMORIM, Celso e PIMENTEL, Renata. "Iniciativa para as Amércias 'O Acordo do Jardim das Rosas"'. In: ALBUQUERQUE, José Augusto Guilhon (org.). Sessenta Anos de Política Externa Brasileira (1930-1990). Volume II: Diplomacia para o desenvolvimento. São Paulo: NUPRI, 1996.

AMORIM, Celso Luiz Nunes. "Celso Amorim (depoimento, 1997)". Rio de Janeiro, CPDOC, 2003.

AMORIM, Celso. "A integração sul-americana”. Diplomacia, Estratégia \& Política, no. 10, out/dez 2009. 
ARAUJO, Motta. A história do Istituto per la Riconstruzione Industriale, 15 de maio de 2014. Disponível em http://jornalggn.com.br/noticia/a-historia-do-istituto-per-la-ricostruzione-industriale. Acesso em 20/05/2014.

ARBILLA, José María. "Arranjos Institucionais e Mudança Conceitual nas Políticas Externas Argentina e Brasileira (1989-1994)”. Contexto Internacional, vol. 22, no. 2, 2000.

AZAMBUJA, Marcos Castrioto de. "A Política Externa do Governo Collor”. São Paulo: Instituto de Estudos Avançados, 1991.

AZAMBUJA, Marcos Castrioto de. "O Relacionamento Brasil-Argentina: de rivais a sócios". In: FONSECA JÚNIOR, Gelson e CASTRO, Sérgio Henrique Nabuco de. Temas de Política Externa Brasileira II, volume 2. Brasília/São Paulo: FUNAG/Paz e Terra, 1997.

AZAmbuja, Marcos Castrioto de. A Política Externa do Governo Collor. São Paulo: Instituto de Estudos Avançados, 1991.

BANCO DO BRASIL. "Documento de posição: fatos relativos ao contencioso do Grupo Mendes Júnior com o Governo do Iraque", 03 de novembro de 1993.

BANCO DO BRASIL. "Parecer COJUR/CONIN-CJA-90/262”, 12 de setembro de 1990.

BARRETO, Fernando de Mello. Os Sucessores do Barão (1964-1985). São Paulo: Paz e Terra, 2006.

BARROS, Alexandre de S. C. "A formulação e implementação da Política Externa Brasileira: o Itamaraty e os novos atores". In: MUÑOZ, Heraldo e TULCHIN, Joseph (eds.). América Latina e a Política Mundial. São Paulo: Convívio, 1986.

BARROS, Sebastião do Rego. Sebastião do Rego Barros II (depoimento, 2009). Rio de Janeiro: CPDOC, 2011.

BATISTA JÚNIOR, Paulo Nogueira. Da Crise Internacional à Moratória Brasileira. São Paulo: Paz e Terra, 1988.

BATISTA, Paulo Nogueira. “A Política Externa de Collor: modernização ou retrocesso?”. Política Externa, vol. 1, no. 4, 1993.

BATISTA, Paulo Nogueira. "O Consenso de Washington: a visão neoliberal dos problemas latinoamericanos". In: Em Defesa do Interesse Nacional: desinformação e alienação do patrimônio público. São Paulo: Paz e Terra, 1994.

BATISTA, Paulo Nogueira. "Perspectivas da Rodada Uruguai: implicações para o Brasil". Estudos Avançados, no. 6, vol. 16, 1992.

BELÉM LOPES, Dawisson. “A política externa brasileira e a 'circunstância democrática': do silêncio respeitoso à politização ruidosa”. Revista Brasileira de Política Internacional, vol. 54, no. 2, 2011.

BELÉM LOPES, Dawisson. Política Externa e Democracia no Brasil: ensaio de interpretação histórica. São Paulo: UNESP, 2013.

BETING, Joelmir. “O choque do engodo”, Folha de São Paulo, 23 de janeiro de 1990, p. B-2.

BRESSER-PEREIRA, Luiz Carlos. Os tempos heroicos de Collor e Zélia. São Paulo: Editora Nobel, 1991. 
BROOKE, James. “A Swift and Hard Fall for Brazil”, New York Times, 10 de abril de 1990.

BRUNEAU, Thomas. "Brazil's Political Transition". In: HIGLEY, John e GUNTHER, Richard (eds.). Elites and Democratic Consolidation in Latin America and Southern Europe. Cambridge: Cambridge University Press, 1992.

BRZEZINSKI, Zbgniew. O Grande Fracasso. Rio de Janeiro: Bibliex, 1990.

BUSH, George. "Remarks Announcing the Enterprise for the Americas Initiative", 27 de junho de 1990. Disponível em http://www.presidency.ucsb.edu/ws/?pid=18644. Acesso em 12/09/2014.

CÂMARA DOS DEPUTADOS. "Dramaticidade foi o tom dos discursos de Collor e Goulart". Disponível em: http://www2.camara.leg.br/camaranoticias/noticias/POLITICA/192177DRAMATICIDADE-FOI-O-TOM-DOS-DISCURSOS-DE-COLLOR-E-GOULART.html. Acesso em $25 / 09 / 2013$.

CAMARGO, Sonia de; VÁSQUEZ OCAMPO, José María. Autoritarismo e Democracia na Argentina e Brasil. São Paulo: Convívio, 1988.

CAMPOS, Roberto. “De volta à gafieira...”. O Globo, 15 de setembro de 1991, p. 3.

CAMPOS, Roberto. “Moscou revisitada”. O Estado de São Paulo, 30 de janeiro de 1990, p. 2.

CAMPOS, Roberto. Lanterna na Popa. Rio de Janeiro: Topbooks, 1994.

CANANI, Ney. Política Externa no Governo Itamar Franco. Porto Alegre: Ed. UFRGS, 2004.

CARDOSO, Fernando Henrique. “A coesão necessária”. FSP, 18 de outubro de 1990, p. A-2.

CARNEIRO, Dionísio Dias. "Perspectivas do endividamento externo brasileiro, 1986-1990". Contexto Internacional, vol. 3, ano 2, 1986.

CAROTHERS, Thomas. "The United States and Latin America after de Cold War" (Trabalho preparado para o Woodrow Wilson Center for International Scholars). In: VELLOSO, João Paulo dos Reis Velloso (org.). O Brasil e o Plano Bush: oportunidades e riscos numa futura integração das Américas. São Paulo: Nobel, 1991.

CASARÕES, Guilherme. "A Economia Política do Governo Collor: discutindo a viabilidade de governos minoritários sob o presidencialismo de coalizão". Dissertação de mestrado (DCP-USP). São Paulo, 2008.

CASARÕES, Guilherme. "As três camadas da política externa do governo Collor: poder, legitimidade e dissonância”. Dissertação de mestrado (Programa San Tiago Dantas). São Paulo, 2011.

CASARÕES, Guilherme. "O Papel do Itamaraty na definição da política externa do governo Collor de Mello”. Revista Brasileira de Política Internacional, vol. 55, no. 1, 2012.

CASON, Jeffrey; POWER, Timothy. "Presidentialization, pluralization, and the rollback of Itamaraty: explaining change in Brazilian Foreign Policy making in the Cardoso-Lula Era". International Political Science Review, vol. 30, no. 2, 2009, pp. 117-140.

CASTRO, Flávio Mendes de Oliveira e CASTRO, Francisco Mendes de Oliveira. 1808-2008 Dois Séculos de História do Itamaraty. Volume 2 (1979-2008). Brasília: FUNAG, 2009. 
CEPALUNI, Gabriel. Regime de Patentes: Brasil x Estados Unidos no tabuleiro internacional. São Paulo: Aduaneiras, 2006.

CERQUEIRA, Ceres Aires. Dívida Externa Brasileira. Brasília: Banco Central do Brasil, 2003. CERVO, Amado e BUENO, Clodoaldo. História da Política Exterior do Brasil. Brasília: UnB, 2002.

CERVO, Amado e BUENO, Clodoaldo. História da Política Exterior do Brasil. 2a ed. Brasília: Ed. UnB, 2002.

CERVO, Amado Luiz. "Política de Comércio Exterior e Desenvolvimento: a experiência brasileira". Revista Brasileira de Política Internacional, vol. 40, no. 2, 1997.

CERVO, Amado Luiz. "Política Exterior e Relações Internacionais do Brasil: enfoque paradigmático". Revista Brasileira de Política Internacional, vol. 46, no. 2, 2003.

CHEIBUB, Zairo. "Diplomacia e Construção Institucional: o Itamaraty em perspectiva histórica". Dados, vol. 28, no. 1, 1985.

CIDOB, "Carlos Andrés Pérez Rodríguez", disponível em http://www.cidob.org/es/documentation/biografias_lideres_politicos/america_del_sur/venezuela/carlos _andres_perez_rodriguez. Acesso em 14/02/2014.

COELHO, Marcelo. "Sarneyzismo". Folha de São Paulo, 20 de maio de 1991, p. 1-2.

COLLOR DE MELLO, Fernando. "Discurso à XLV Sessão Ordinária da Assembleia Geral da Organização das Nações Unidas (1990)" In: SEIXAS-CORRÊA, Luiz Felipe. A Palavra do Brasil nas Nações Unidas: 1946 - 2006. Brasília: FUNAG, 2007.

COLLOR DE MELLO, Fernando. "O Projeto de Reconstrução Nacional”. Brasília: Biblioteca da Presidência da República, 1990.

COLLOR DE MELLO, Fernando. "Projeto Brasil Novo". In: CLARET, Martin. O Fenômeno Collor. São Paulo: Martin Claret, 1989.

CONCA, Ken. Technology, the military, and democracy in Brazil. Journal of Interamerican Studies and World Affairs, vol. 34, no. 1, 1992.

CONGRESSIONAL RECORD. "Revelations concerning Brazil's nuclear weapon program". (101st Congress, 1989-1990). 22 de outubro de 1990.

CÔRTES, Octávio Henrique Dias Garcia. A Política Externa do Governo Sarney: o início da reformulação de diretrizes para a inserção internacional do Brasil sob o signo da democracia. Brasília: FUNAG, 2010.

CRUZ JR, Ademar Seabra de; CAVALCANTE, Antonio Ricardo F.; PEDONE, Luiz. "Brazil's Foreign Policy Under Collor". Journal of Interamerican Studies and World Affairs, vol. 35, no. 1, 1993.

CRUZ JR., Ademar Seabra de; CAVALCANTE, Antonio Ricardo F.; PEDONE, Luiz. "Brazil's Foreign Policy Under Collor". Journal of Interamerican Studies and World Affairs, vol. 35, no. 1, 1993.

DANDEKER, Rebecca D. "The Rose Garden Agreement: is Mercosur the next step to a hemispheric free trade zone?". Law and Policy in International Business, vol. 24, no. 1, 1992. 
DANESE, Sérgio França. Diplomacia Presidencial: história e crítica. Rio de Janeiro: Topbooks, 1999.

DANESE, Sérgio. Diplomacia Presidencial. Rio de Janeiro: Topbooks, 1999.

DAUSTER, Jório. “Depoimento de Jório Dauster”, Insight Inteligência, out-nov-dez 2013, p. 23.

DE FREITAS, Jânio. “Ainda é uma esfinge”, Folha de São Paulo, 17 de janeiro de 1990, p. A-5.

DEVLIN, Robert. "From Baker to Brady: can the new plan work?". Revista de Economia Política, vol. 10, no. 2, 1990.

DEVOTO, Leonor Machinandiarena de. Historia del MERCOSUR: desde su fundación hasta el año 2000. Buenos Aires: CIEG, 2006.

DIMENSTEIN, Gilberto. “A aposta de Sarney”, Folha de São Paulo, 06 de janeiro de 1990, p. A-2.

DIMENSTEIN, Gilberto. “A OLP e as eleições”, Folha de São Paulo, 15 de agosto de 1989, p. A-2.

DIMENSTEIN, Gilberto. “Covas versus Covas”, Folha de São Paulo, 04 de julho de 1989, p. A-2.

DIMENSTEIN, Gilberto. "Dança com lobos”. Folha de São Paulo, 10 de setembro de 1991, p. 1-2.

DIMENSTEIN, Gilberto. "Delfim ironiza Covas", Folha de São Paulo, 05 de julho de 1989, p. A-2.

DIMENSTEIN, Gilberto. "Yes, nos temos ministro", Folha de São Paulo,11 de maio de 1991, p. 1-2.

ESCUDÉ, Carlos. Foreign Policy Theory in Menem's Argentina. Gainesville: University Press of Florida, 1997.

ESPIELL, Hector Gros. "Quatro mais um igual a dois", OESP, 19 de junho de 1991, p. 2.

EVANS, Peter. "Declining Hegemony and assertive industrialization: U.S.-Brazil conflicts in the computer industry". International Organization, vol. 43, no. 2, 1989.

EVANS, Peter. "Informática: a metamorfose da dependência". Novos Estudos CEBRAP, no. 15, 1986.

FARES, Seme Taleb. "O Pragmatismo do Petróleo: as relações entre o Brasil e o Iraque”. Revista Brasileira de Política Internacional, vol. 50, no. 2, 2007.

FARIA, Tales. "Raposas à solta”. Folha de São Paulo, 21 de junho de 1989, p. A-2.

FERNANDEZ, Wilson. Mercosur: economia, politica y estrategia en la integracion. Montevideo: FCU, 1992.

FERREIRA, Oliveiros S. "A Dívida Externa Brasileira no Contexto da Crise Mundial: uma visão nãoortodoxa”. Política e Estratégia, vol. 2, no. 3, 1984.

FERREIRA, Túlio Sérgio Henriques. "A ruína do consenso: a política exterior do Brasil no governo Figueiredo (de 1979 a 1985). Revista Brasileira de Política Internacional, vol. 49, no. 2, 2006.

FERREIRA, Túlio Sérgio Henriques. O Universalismo e seus descontentes: a política exterior do Brasil no governo Figueiredo (de 1979 a 1985). Curitiba: Juruá, 2009. 
FIGUEIREDO, Argelina Cheibub. "Government Coalitions in Brazilian Democracy". Brazilian Political Science Review, vol. 1, no. 2, 2007.

FISHLOW, Albert. "Flying Down to Rio: perspectives on U.S.-Brazil Relations". Foreign Affairs, winter 1978/1979.

FLECHA DE LIMA, Paulo Tarso. "Modernização e obstáculos para a Internacionalização da Economia Brasileira". Revista Brasileira de Política Internacional, ano XXXI, no. 123-4, 1988.

FONSECA JR., Gelson. A Legitimidade e Outras Questões Internacionais. São Paulo: Paz e Terra, 1998.

FRANCIS, Paulo. "George Bush intercede pelo México, mas não pelo Brasil”, Folha de São Paulo, 08 de julho de 1989, p. B-4.

FREITAS, Janio de. “A saída e a entrada”. Folha de São Paulo, 10 de maio de 1991, p. 1-5.

FREITAS, Jânio de. "Missão de desacordo", Folha de São Paulo, 20 de julho de 1991, p. 1-5.

FRIEDEN, Jeffry. "Actors And Preferences In International Relations". In: LAKE, David A e POWELL, Robert. Strategic Choice And International Relations. NY: Princeton University Press, 1999.

FRITSCH, Winston. "Rumos da Política Econômica Externa Brasileira". Contexto Internacional, vol. 2, ano 1, 1985.

FUKUYAMA, Francis. “The End of History?” The National Interest, summer 1989.

GOUVÊA, Leila Vilas Boas. Modernização ou Sucateamento? Política Industrial e de Comércio Exterior. São Paulo: Círculo do Livro, 1991.

GUIMARÃES, Ulysses. “Sem cidadania não há democracia”, OESP, 15 de março de 1992, p. 7.

GURRÍA, José Angel. La Política de la Deuda Externa. México, DF: Fondo de Cultura Económica, 1993.

HALLIDAY, Fred. The Making of the Second Cold War. London: Verso, 1985.

HERMANN, Charles. "Changing Course: when governments choose do redirect foreign policy". International Studies Quarterly, 34, 1990.

HIRST, Monica e PINHEIRO, Letícia. "A Política Externa do Brasil em dois tempos". Revista Brasileira de Política Internacional, vol. 38, no. 1, 1995.

HIRST, Monica e PINHEIRO, Letícia. "A Política Externa do Brasil em dois tempos". Revista Brasileira de Política Internacional, vol. 38, no. 1, 1995.

HUNTINGTON, Samuel P. “A Mudança nos Interesses estratégicos americanos”. Política Externa, vol. 1, no. 1, 1992.

KEOHANE, Robert e GOLDSTEIN, Judith. "Ideas and Foreign Policy: an analytical framework". In: Ideas and Foreign Policy. Ithaca: Cornell University Press, 1993.

KINGSTONE, Peter. Crafting Coalitions for Reform: business preferences, political institutions, and neoliberal reform in Brazil. University Park: The Pennsylvania State University Press, 1999. 
LAFER, Celso e FONSECA JR., Gelson. "Questões para a diplomacia no contexto internacional das polaridades indefinidas (notas analíticas e algumas sugestões)". In: FONSECA JR., Gelson e CASTRO, Sérgio H. N. (orgs.). Temas de Política Externa II. Brasília/São Paulo: Funag/Paz e Terra, 1994.

LAFER, Celso et al. José Guilherme Merquior, Diplomata. Brasília: IPRI, 1993.

LAFER, Celso. “A inserção internacional do Brasil”. O Estado de São Paulo, 23 de maio de 1992a, p. 2.

LAFER, Celso. "Brasil: dilemas e desafios da política externa". Estudos Avançados, vol. 14, no. 38, 2000.

LAFER, Celso. "Cerimônia de posse no cargo de Ministro de Estado das Relações Exteriores". In: Ministério das Relações Exteriores, 1993.

LAFER, Celso. "Entrevista com Celso Lafer”. Estudos Históricos, vol. 6, no. 12, 1993.

LAFER, Celso. "O legado diplomático da viagem presidencial de Tancredo Neves". Contexto Internacional, vol. 2, no. 1, 1985.

LAFER, Celso. "O Significado da Rio-92 e os Desafios da Rio+20”. Política Externa, vol. 21, no. 1, 2012.

LAFER, Celso. "Perspectivas da Política Externa: o legado da viagem presidencial de Tancredo Neves". Contexto Internacional, vol. 2, no. 1, 1985.

LAFER, Celso. "Perspectivas e possibilidades da inserção internacional do Brasil". Política Externa, vol. 1 , no. 3, 1992.

LAFER, Celso. Ensaios Liberais. São Paulo: Siciliano, 1991. Ver também Paim, Antonio. "Contribuição de Celso Lafer ao Liberalismo Brasileiro". Revista USP, no. 27, 1995.

LAFER, Celso. O Brasil e a Crise Mundial. São Paulo: Perspectiva, 1984.

LAMPREIA, Luiz Felipe. Luiz Felipe Lampreia (depoimento, 2008). Rio de Janeiro, CPDOC, 2010.

LAVAGNA, Roberto. "Integração Argentina-Brasil: origens, resultados e perspectivas". In: VEIGA, Pedro da Motta. Cone Sul: a economia política da integração. Rio de Janeiro: FUNCEX, 1991.

LERER, David. "Perestroika na África”. Folha de São Paulo, 12 de setembro de 1991, p. 1-3.

LESSA, Antônio Carlos. "A diplomacia universalista do Brasil: a construção do sistema contemporâneo de relações bilaterais". Revista Brasileira de Política Internacional, vol. 41, no. 2, 1998.

LESSA, Antônio Carlos; SPEKTOR, Matias e CHIARELLI, Paulo José. "Cronologia das Relações Internacionais Contemporâneas e da Política Externa Brasileira". Cena Internacional, ano 2, no. 1, 2000.

LIMA, Lucas Barbosa. "O Negociador: um perfil do Embaixador Paulo Nogueira Batista”. JUCA: diplomacia e humanidades, ano 4, 2010. 
LIMA, Maria Regina Soares de. "A Economia Política da Política Externa Brasileira”. Contexto Internacional, vol. 12, ano 6, 1990.

LIMA, Maria Regina Soares de. "Ejes Analíticos y Conflicto de Paradigmas en la Política Exterior Brasileña". America Latina/Internacional, vol. 1, no. 2, 1994.

LIMA, Maria Regina Soares de. "Instituições Democráticas e Política Exterior". Contexto Internacional, vol. 22, no. 2, 2000.

LIMA, Maria Regina Soares de. The political economy of Brazilian foreign policy: nuclear energy, trade and itaipu. Brasília: FUNAG, 2013.

LIMA, Maria Regina Soares de; HIRST, Mônica. "O Brasil e os Estados Unidos: dilemas e desafios de uma relação complexa". In: FONSECA JÚNIOR, Gelson; CASTRO, Sérgio Henrique Nabuco. Temas de Política Externa Brasileira II. Volume 2. São Paulo: Paz e Terra, 1994.

LINS DA SILVA, Carlos Eduardo. "Ausência veio na hora certa”, Folha de São Paulo, 04 de julho de 1989, p. A-4.

LINS DA SILVA, Carlos Eduardo. "O candidato de plástico". Folha de São Paulo, 28 de maio de 1989, p. A-2.

LOHBAUER, Christian. Brasil-Alemanha: fases de uma parceria 1964-1999. São Paulo: KAS/EDUSP, 2000.

LÓPEZ MAYA, Margarita. "The Venezuelan Caracazo of 1989: popular protest and institutional weakness", Journal of Latin American Studies, vol. 35, 2003.

LOWENTHAL, Abraham F. "Rediscovering Latin America”. Foreign Affairs, fall 1990.

MARTINS, Rui. "O Itamaraty na Época da Ditadura”. 25/06/2011. Disponível em http://www.diretodaredacao.com/noticia/o-itamaraty-na-epoca-da-ditadura. Acesso em 08/08/2011.

MDIC. Dados comerciais Brasil-Iraque. MDIC, 2012.

MEARSHEIMER, John J. The False Promise of International Institutions. International Security, vol. 19 , no. $3,1995$.

MELLO, Flávia de Campos. "Política externa brasileira e os Blocos Internacionais". São Paulo em Perspectiva, vol. 16, no. 1, 2002.

MELLO, Flávia de Campos. "Regionalismo e Inserção Internacional: continuidade e transformação da política externa brasileira nos anos 90". Tese de doutorado, FFLCH/USP, 2000.

MELO, Carlos. Collor: o ator e suas circunstâncias. São Paulo: Novo Conceito, 2007.

MENDES, Manuel. O Cerrado de Casaca. Brasília: Thesaurus, 1995.

MENENDEZ, Cristina e KERZ, Mercedes. Autocracia y Democracia: Brasil - un camino al Mercosur. Buenos Aires: Editorial de Belgrano, 1993.

MERCOSUR. "Comunicado de Las Leñas", 27 de junho de 1992. Revista de Relaciones

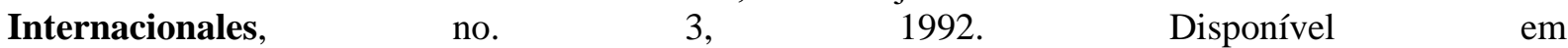
http://www.iri.edu.ar/revistas/revista_dvd/revistas/R3/R3DOC07.html. Acesso em 10/02/2014. 
MERQUIOR, José Guilherme. "Brazil's New Republic: The Social-Liberal Path". Bulletin of Latin American Review, vol. 6, no. 2, 1987.

MILHOLIN, Gary e DANTZIC, David. "Must the U.S. Give Brazil and Iraq The Bomb?" The New York Times, 29 de julho de 1990.

MINISTÉRIO DA ECONOMIA, FAZENDA E PLANEJAMENTO. "Relatório Final", 23 de junho de 1992.

MIYAMOTO, Shiguenoli. "A Inserção do Brasil no Sistema Internacional”. São Paulo em Perspectiva, vol. 5, no. 3, 1991.

MIYAMOTO, Shiguenoli. “A Inserção do Brasil no Sistema Internacional”. São Paulo em Perspectiva, vol. 5, no. 3, 1991.

MOISÉS, José Álvaro (org.). O Futuro do Brasil: a América Latina e o fim da Guerra Fria. São Paulo: Paz e Terra, 1991.

MONIZ BANDEIRA, Luiz Alberto. Relações Brasil-EUA no Contexto da Globalização. São Paulo: Ed. SENAC, 1999.

MOREIRA, Marcílio Marques. Diplomacia, Política e Finanças. Rio de Janeiro: Objetiva, 2001.

MORGENTHAU, Hans J. A Política Entre as Nações. Brasília: IPRI/FUNAG, 2003.

MOURA, Gerson. Autonomia na Dependência. Rio de Janeiro: Nova Fronteira, 1980.

NOBLAT, Ricardo. O Céu dos Favoritos: o Brasil de Sarney a Collor. Rio de Janeiro: Rio Fundo, 1990.

NÓBREGA, Maílson da. "Presença do Estado na Economia e na Sociedade". In: LAMOUNIER, Bolívar (org.). Ouvindo o Brasil: uma análise da opinião pública brasileira hoje. São Paulo: IDESP, 1992.

OCDE. "Secretario General Designado". Disponível em: http://www.oecd.org/mexico/35147118.pdf. Acesso em 12/10/2014.

ODELL, John. "International Threats and Internal Politics: Brazil, the European Community, and the United States, 1985-1987”. In: PUTNAM, Robert et al. (org.). Double-Edged Diplomacy. Berkeley: University of California Press, 1993.

OLIVEIRA, Amâncio e ONUKI, Janina. "Eleições, partidos políticos e política externa no Brasil". Política Hoje (UFPE), vol. 19, 2010.

OLIVEIRA, Eliézer Rizzo de. De Geisel a Collor: forças armadas, transição e democracia. Campinas: Papirus, 1994.

OLIVEIRA, Odete Maria de. "A integração bilateral Brasil-Argentina: tecnologia nuclear e Mercosul”. Revista Brasileira de Política Internacional, vol. 41, no. 1, 1998.

PATRIOTA, Antonio de Aguiar. O Conselho de Segurança após a Guerra do Golfo: a articulação de um novo paradigma de segurança coletiva. Brasília: FUNAG, 1998.

PENNA FILHO, Pio e LESSA, Antônio Carlos. "O Itamaraty e a África: as origens da política africana no Brasil”. Estudos Históricos, vol. 39, no. 1, 2007. 
PEREIRA, Analúcia Danilevicz. "O Brasil em crise e o mundo em transição: política exterior brasileira de Sarney a Collor”. Ciências e Letras, no. 37, 2005.

PEREIRA, Analúcia Danilevicz. A Política Externa do Governo Sarney. Porto Alegre: Ed. UFRGS, 2003.

PEREIRA, José Maria Nunes. "Brasil-África no Governo Figueiredo: um balanço". Contexto Internacional, vol. 1, no. 2, 1985.

PEREIRA, José Mário. “O Fenômeno Merquior”. 2001. Disponível em http://www.olavodecarvalho.org/convidados/0122.htm

PINHEIRO, Letícia. "Os véus da transparência: política externa e democracia no Brasil". IRI Textos, no. 25, 2003.

PINHEIRO, Letícia. "Traídos Pelo Desejo: um ensaio sobre a teoria e a prática da Política Externa Brasileira Contemporânea”. Contexto Internacional, vol. 22, no. 2, 2000.

PINHEIRO, Leticia. Foreign Policy Decision-Making Under the Geisel Government: the president, the military and the Foreign Ministry. Brasília: FUNAG, 2013.

PIO, Carlos. "A Estabilização Heterodoxa no Brasil: ideias e redes políticas". Revista Brasileira de Ciências Sociais, vol. 16, no. 46, 2001, pp. 29-54.

PLÁ, Juan Algorta. "O Comércio Brasil-Argentina: tendências observadas nos últimos 20 anos". Indicadores Econômicos FEE, vol. 20, no. 1, 1992, pp. 158-174.

PORTAL BRASIL. "Índice Nacional de Preços ao Consumidor Amplo Especial (IPCA-E)". Disponível em http://www.portalbrasil.net/ipca_e.htm. Acesso em 9/8/2014.

PRZEWORSKI, Adam. “The Neoliberal Fallacy”. Journal of Democracy, vol. 3, no. 3, 1992.

PUTNAM, Robert. "Diplomacy and Domestic Politics: the logic of two-level games". International Organization, vol. 42, no. 3, 1988.

REIS VELLOSO, João Paulo dos. "Alternativas do Brasil em face da Iniciativa Bush". In: REIS VELLOSO, João Paulo dos (org.). O Brasil e o plano Bush: oportunidades e riscos numa futura integração das Américas. São Paulo: Nobel, 1991.

REIS, Carlos Nelson dos; FISCHER, Sérgio; CAMPOS, Silvia Horst. "Programa Iniciativa para as Américas (Plano Bush): algumas considerações". Indicadores Econômicos FEE, vol. 18, no. 2, 1990.

REPÚBLICA FEDERATIVA DO BRASIL. Declaração de Iperó, 8 de abril de 1988. Disponível em http://dai-mre.serpro.gov.br/atos-internacionais/bilaterais/1988/b_19/. Acesso em 11/10/2014.

RIBEIRO, Cláudio Oliveira. "Adjustment Changes: a política africana do Brasil no pós-Guerra Fria". Revista de Sociologia e Política, vol. 18, no. 35, 2010, pp. 55-79.

RIBEIRO, Cláudio Oliveira. "As relações Brasil-África entre os governos Collor e Itamar Franco". Revista Brasileira de Ciência Política, no. 1, 2009.

RIBEIRO, Cláudio Oliveira. "As Relações Brasil-África entre os governos Collor e Itamar Franco". Revista Brasileira de Ciência Política, no. 1, jan/jun 2009, pp. 289-329. 
RIBEIRO, Cláudio Oliveira. "Crise e Castigo: as relações Brasil-África no governo Sarney”. Revista Brasileira de Política Internacional, vol. 51, no. 2, 2008, pp. 39-59.

RICUPERO, Rubens. "Comércio e Desenvolvimento na Periferia do Capitalismo". Perspectivas [São Paulo], v. 32, 2007, p. 217-231.

RICUPERO, Rubens. Diário de Bordo: a viagem presidencial de Tancredo. São Paulo: Imprensa Oficial, 2010.

RODRIGUES, Newton. "Pesquisas e abusos", Folha de São Paulo, 29 de setembro de 1989, p. A-2.

RODRIGUES, Newton. "Um quisto a extirpar”. Folha de São Paulo, 23 de janeiro de 1990, p. A-2.

RODRIGUES, Newton. "Viagem de candidato", Folha de São Paulo, $1^{\circ}$ de julho de 1989, p. A-2.

ROSA E SILVA, Cláudio Humberto. Mil Dias de Solidão: Collor bateu e levou. São Paulo: Geração Editorial, 1993.

ROSS, Maxim. "La deuda externa intralatinoamericana: el caso Venezuela". Integración Latinoamericana, mayo de 1989.

ROSSI, Clóvis. “Collor, visto de perto”. Folha de São Paulo, 28 de maio de 1989, p. A-2.

ROSSI, Clóvis. “Menem, o tênis e Collor”, Folha de São Paulo, 17 de janeiro de 1990, p. A-2.

ROSSI, Clóvis. “O que é bom para quem”. Folha de São Paulo, 22 de junho de 1991, p. 1-2.

SABINO, Fernando. Zélia: uma paixão. São Paulo: Record, 1991.

SALLUM JR., Brasilio. Governo Collor: o reformismo liberal e a nova orientação da política externa brasileira. Dados, vol.54, no.2, Rio de Janeiro, 2011.

SALLUM JR., Brasilio. Labirintos: dos generais à Nova República. São Paulo: Hucitec, 1995.

SANCHEZ, Michelle Ratton et al. "Política Externa como Política Pública: uma análise pela regulamentação constitucional brasileira (1967-1988)". Revista de Sociologia e Política, no. 27, 2006, pp. 125-143.

SARAIVA, Miriam Gomes. "A Opção Europeia e o Projeto de Brasil Potência Emergente". Contexto Internacional, vol. 11, ano 6, 1990, pp. 95-117.

SARNEY, José. "Audiência aos Estagiários da Escola Superior de Guerra". Discurso proferido no Palácio do Planalto, em 13 de junho de 1988. Disponível em http://www.biblioteca.presidencia.gov.br/ex-presidentes/jose-sarney/discursos/1988/49.pdf

SARNEY, José. “Brazil: a president’s story”. Foreign Affairs, Fall 1986.

SCHWARTZ, Gilson. "O Brasil que sabe dizer sim: caminhos em direção ao Japão”. São Paulo em Perspectiva, vol. 4, no. 3, 1991.

SEITENFUS, Ricardo. “Considerações sobre o Mercosul”. Estudos Avançados, vol. 6, no. 16, 1992.

SEIXAS CORRÊA, Luiz Felipe de. "Prefácio". In: Ministério das Relações Exteriores. A Inserção Internacional do Brasil: a gestão do Ministro Celso Lafer no Itamaraty. Brasília: MRE, 1993. 
SEIXAS CORRÊA, Luiz Felipe de. A Palavra do Brasil nas Nações Unidas. Brasília: FUNAG, 2007.

SEIXAS CORRÊA, Luiz Felipe. "A Política Externa de José Sarney”. In: ALBUQUERQUE, José Augusto Guilhon et al. Sessenta Anos de Política Externa Brasileira (1930-1990). $2^{a}$. Ed. São Paulo: Lumen Juris, 2006.

SETTI, Ricardo. “Collor e a catástrofe”. OESP, 12 de setembro de 1991, p. 2.

SIMON, Roberto. "As duas aberturas: redemocratização e política internacional no Brasil de Figueiredo (1979-1985)”. Dissertação de mestrado (Programa San Tiago Dantas). São Paulo, 2013.

SINGER, André. “Acabou a geléia”. Folha de São Paulo, 23 de julho de 1989, p. A-2.

SOLA, Lourdes. "Estado, transformação econômica e democratização no Brasil". In: SOLA, Lourdes (org.). Estado, Mercado e Democracia. Rio de Janeiro: Paz e Terra, 1993.

SPEKTOR, Matias. “Collor estadista?”. Folha de São Paulo, 27 de fevereiro de 2012.

SPEKTOR, Matias. 18 Dias. Rio de Janeiro: Record, 2014.

SPEKTOR, Matias. Kissinger e o Brasil. Rio de Janeiro: Record, 2009.

SPINOLA, Noenio. "Rússia para Collor ver”. O Estado de São Paulo, 30 de janeiro de 1990, p. 2.

SUPLICY, Eduardo Matarazzo. "O acordo dos juros atrasados". Folha de São Paulo, 23 de junho de 1991, p. 1-3.

TAPIA, Jorge Rubem Biton. A Trajetória da Política de Informática Brasileira. São Paulo/Campinas: Papirus/Unicamp, 1995.

THE BUSH PRESIDENTIAL LIBRARY. "Statement by Press Secretary Fitzwater on President Bush's Meeting With President-Elect Fernando Collor de Mello of Brazil”, 26 January 1990. Disponível em http://bushlibrary.tamu.edu/research/public_papers.php?id=1477\&year=1990\&month=01. Acesso em $12 / 05 / 2014$.

TILLY, Charles. "Means and Ends of Comparison in Macrosociology". Comparative Social Research, vol. 16, 1997.

TSEBELIS, George. Veto Players: How Political Institutions Work. NY: Russell Sage, 2002.

UEHARA, Alexandre Ratsuo. "Relações Brasil-Japão: aproximações e distanciamentos". Carta Asiática, 1999.

UNESCO. Educação e Conhecimento: a experiência dos que avançaram. Brasília: UNESCO, 2004.

UNITED NATIONS. Yearbook of the United Nations (1992). New York: Department of Public Information, 1992.

VARGAS, Everton Vieira. "Átomos na integração: a aproximação Brasil-Argentina no campo nuclear e a construção do Mercosul”. Revista Brasileira de Política Internacional, vol. 40, no. 1, 1997.

VAZ, Alcides Costa. Condicionantes da posições brasileiras frente ao desarmamento, regimes de controle de exportações e segurança nacional. Premissas, no. 4, 1993. 
VAZ, Alcides Costa. Cooperação, Integração e Processo Negociador: a construção do Mercosul. Brasília: FUNAG/IPRI, 2002.

VAZ, Alcides Costa. Cooperação, Integração e Processo Negociador: a construção do Mercosul. Brasília: FUNAG/IPRI, 2002.

VEIGA, Pedro da Motta. "Sete hipóteses sobre os processos de regionalização e a integração do Cone Sul”. In: In: VEIGA, Pedro da Motta. Cone Sul: a economia política da integração. Rio de Janeiro: FUNCEX, 1991.

VELASCO e CRUZ, Sebastião Carlos. Estado e Economia em Tempo de Crise: política industrial e transição política no Brasil nos anos 80. Rio de Janeiro/Campinas: Relumé Dumará/Ed. Unicamp, 1997.

VELASCO e CRUZ, Sebastião Carlos. Globalização, Democracia e Ordem Internacional. Campinas/São Paulo: Ed. Unicamp/ Ed. UNESP, 2004

VIGEVANI, Tullo e CEPALUNI, Gabriel. Brazilian Foreign Policy in Changing Times: the quest for autonomy from Sarney to Lula. New York: Lexington Books, 2010.

VIGEVANI, Tullo. O Contencioso Brasil x Estados Unidos da Informática: uma análise sobre formulação da política exterior. São Paulo: EDUSP/Alfa Ômega, 1995.

VIGEVANI, Tullo. O Contencioso Brasil x Estados Unidos da Informática: uma análise sobre formulação da política exterior. São Paulo: EDUSP/Alfa Ômega, 1995.

VIGEVANI, Tullo; OLIVEIRA, Marcelo Fernandes de; CINTRA, Rodrigo. "Política Externa no Governo FHC: a busca da autonomia pela integração”. Tempo Social, 2003.

VIZENTINI, Paulo Fagundes. "O Brasil, o Mercosul e a integração da América do Sul”. Revista de Estudos e Pesquisas sobre as Américas, vol. 1, no. 1, 2007.

VIZENTINI, Paulo G. Fagundes. "A Política Externa Brasileira em Transição: do desenvolvimentismo ao neoliberalismo". In: MARTINS, Estevão Chaves de Rezende (org.). Relações Internacionais: visões do Brasil e da América Latina. Brasília: IBRI, 2003.

VUSKOVIC, Pedro. "O FMI e a Crise Econômica da América Latina". Novos Estudos CEBRAP, no. $15,1986$.

WAACK, William. "De Paris a Mombaça, tudo é festa". OESP, 25 de julho de 1989, p. 2.

WALD, Arnoldo. “O Plano Bush”. O Globo, 3 de fevereiro de 1990, p. 4.

WALTZ, Kenneth. Man, the State, and War. New York: Columbia University Press, 1959.

WALTZ, Kenneth. Theory of International Politics. New York: McGraw Hill, 1979.

WATKINS, Thayer. "Privatization in France". Disponível em http://www.sjsu.edu/faculty/watkins/privFrance.htm. Acesso em 12/02/2014.

WENDT, Alexander. "Anarchy is What States Make of It: the social construction of power politics". International Organization, vol. 46, no. 2, 1992. 
WENDT, Alexander. "Collective Identity Formation and the International State". American Political Science Review, vol. 88, no. 2, 1994.

WILLIAMSON, John. "What Washington Means by Policy Reform", 1989. Disponível em http://www.iie.com/publications/papers/paper.cfm?researchid=486 . Acesso em 13/02/2014.

WORLD BANK. Argentina: from insolvency to growth. Washington, D.C.: World Bank, 1993.

ZAVERUCHA, Jorge. Frágil Democracia: Collor, Itamar, FHC e os Militares”. Rio de Janeiro: Ed. Civilização Brasileira, 2000.

ZINI JÚNIOR, Álvaro Antônio. "O Brasil num cruzamento: dívida externa e exaustão físcal”. Revista de Economia Política, vol. 10, no. 1, 1990.

Arquivos:

Ministério das Relações Exteriores (Brasília, DF)

The George Bush Library and Museum

Jornais e revistas:

Clarín (várias edições)

Folha de São Paulo (várias edições)

Jornal do Brasil (várias edições)

O Estado de São Paulo (várias edições)

O Globo (várias edições)

The New York Times (várias edições)

Veja (várias edições)

Entrevistas e depoimentos:

José Francisco Rezek (Ministro das Relações Exteriores, 1990-1992), 04/05/2011;

João Santana (Secretário da Administração Federal, 1990-1992), 04/05/2011;

Marcos Azambuja (Secretário Geral de Política Exterior, 1990-1992), 18/05/2011;

Gelson Fonseca Júnior (Embaixador, Assessor da Presidência, 1990-1992), 18/05/2011;

Paulo Tarso Flecha de Lima (Secretário Geral do MRE, 1985-1990), 19/05/2011;

Fernando Collor de Mello (Presidente da República, 1990-1992), 13/06/2011;

Celso Lafer (Ministro das Relações Exteriores, 1992), 03/12/2013;

José Francisco Rezek, entrevistas concedidas ao CPDOC-FGV e conduzidas pelo autor, 24/06 e $02 / 10 / 2014$

Clodoaldo Hugueney (Chefe da Assessoria Internacional do Ministério da Economia, 1990-1991; Chefe do Departamento Econômico do MRE, 1991-1992), 06/10/2014;

Zélia Cardoso de Mello (Ministra da Economia, 1990-1991), 18/10/2014;

Rubens Ricupero (Embaixador do GATT, 1986-1991; Embaixador em Washington, 1991-1994), $30 / 10 / 2014$. 